\title{
Preliminary Evaluation of Removing Used Nuclear Fuel From Nine Shutdown Sites
}

Fuel Cycle Research \& Development

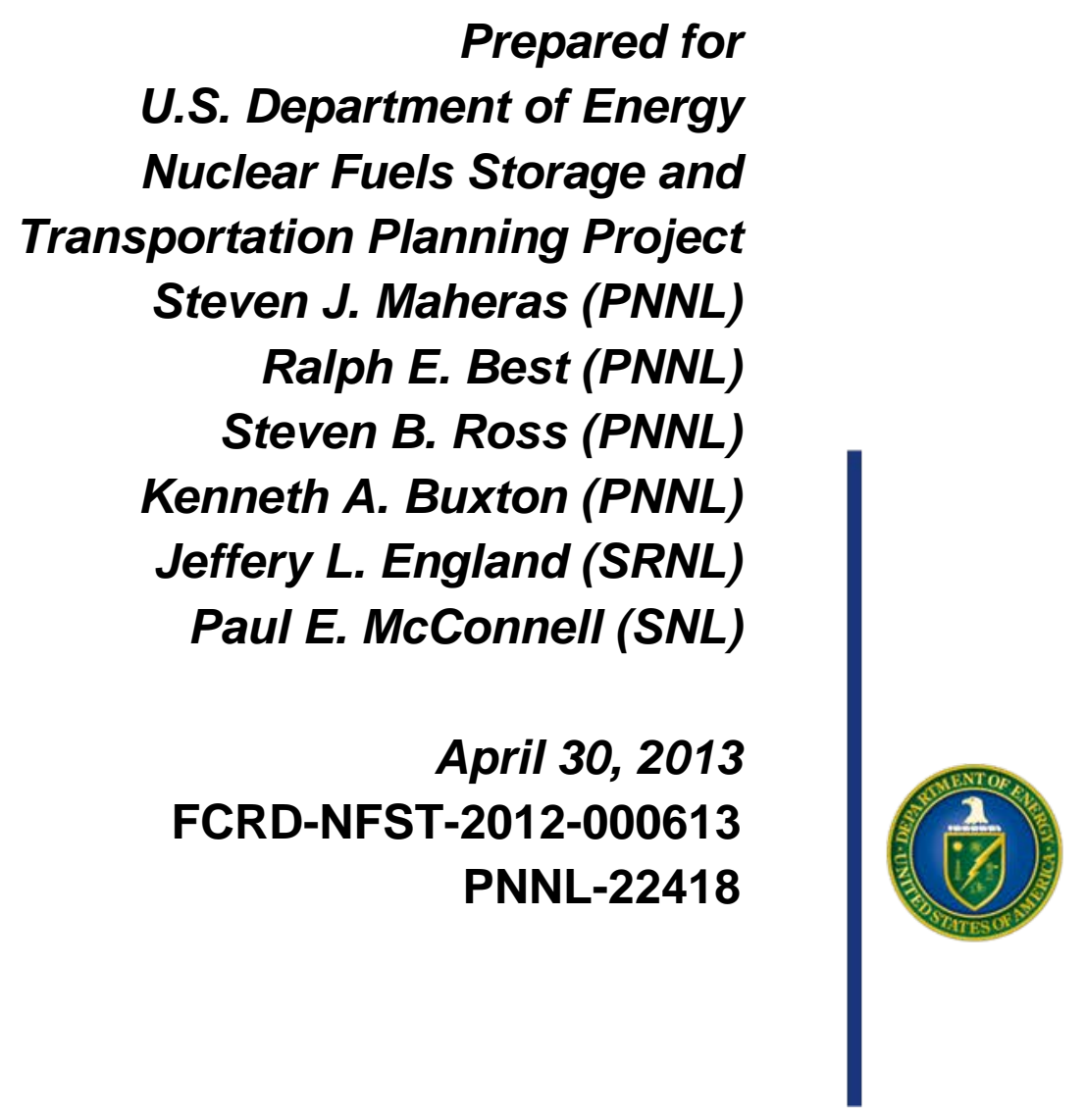




\section{DISCLAIMER}

This information was prepared as an account of work sponsored by an agency of the U.S. Government. Neither the U.S. Government nor any agency thereof, nor any of their employees, makes any warranty, expressed or implied, or assumes any legal liability or responsibility for the accuracy, completeness, or usefulness, of any information, apparatus, product, or process disclosed, or represents that its use would not infringe privately owned rights. References herein to any specific commercial product, process, or service by trade name, trade mark, manufacturer, or otherwise, does not necessarily constitute or imply its endorsement, recommendation, or favoring by the U.S. Government or any agency thereof. The views and opinions of authors expressed herein do not necessarily state or reflect those of the U.S. Government or any agency thereof. 


\section{EXECUTIVE SUMMARY}

This report fulfills the M2 milestone M2FT-12SN0814057, "Status of Stranded Used Nuclear Fuel.”

The Blue Ribbon Commission on America's Nuclear Future identified removal of stranded used nuclear fuel at shutdown sites as a priority so that these sites may be completely decommissioned and put to other beneficial uses (BRC 2012). Shutdown sites are defined as those commercial nuclear power reactor sites where the nuclear power reactors have been shut down and the site has been decommissioned or is undergoing decommissioning. In this report, a preliminary evaluation of removing used nuclear fuel from nine shutdown sites was conducted. The shutdown sites included Maine Yankee, Yankee Rowe, Connecticut Yankee, Humboldt Bay, Big Rock Point, Rancho Seco, Trojan, La Crosse, and Zion. At these sites a total of 7649 used nuclear fuel assemblies and a total of 2813.2 metric tons heavy metal (MTHM) of used nuclear fuel are contained in 248 storage canisters. In addition, 11 canisters containing greater-than-Class C (GTCC) low-level radioactive waste are stored at these sites.

The evaluation was divided in four components:

- characterization of the used nuclear fuel and GTCC low-level radioactive waste inventory at the shutdown sites

- an evaluation of the onsite transportation conditions at the shutdown sites

- an evaluation of the near-site transportation infrastructure and experience relevant to the shipping of transportation casks containing used nuclear fuel from the shutdown sites

- an evaluation of the actions necessary to prepare for and remove used nuclear fuel and GTCC low-level radioactive waste from the shutdown sites.

Using these evaluations the authors developed time sequences of activities and time durations for removing the used nuclear fuel and GTCC low-level radioactive waste from a single shutdown site, from three shutdown sites located close to each other, and from all nine shutdown sites.

Several issues were identified during the characterization of the used nuclear fuel and GTCC low-level radioactive waste inventory at the shutdown sites. The most important of the issues was at the Rancho Seco site, where six damaged fuel assemblies in five of the storage canisters were not placed in failed fuel dry shielded canisters (FF-DSCs). Further evaluation would be needed to determine if the canisters containing this damaged fuel can be shipped in the MP187 transportation cask without repackaging. In addition, the lists of approved contents in the certificates of compliance for the TS125, HI-STAR HB, and MP187 transportation casks do not include GTCC low-level radioactive waste. Consequently, the GTCC low-level radioactive waste stored at the Big Rock Point, Humboldt Bay, and Rancho Seco sites would not be transportable without changes to the certificates of compliance for these transportation casks. Only two of the sites, Maine Yankee and Zion, have high burnup ( $>45$ gigawatt-day per metric ton heavy metal [GWd/MTHM]) used nuclear fuel assemblies in storage. These high burnup used nuclear fuel 
assemblies are packaged, or will be packaged in damaged fuel cans, which would eliminate the concern over the transportability of this high burnup fuel.

As a result of the evaluation of the onsite transportation conditions at the shutdown sites, and the evaluation of the near-site transportation infrastructure and experience in making shipments of large components from the shutdown sites, it was found that all the sites have at least one offsite transportation option for removing their used nuclear fuel and GTCC low-level radioactive waste, and some sites have two options. Table S-1 provides a summary of these transportation options for the shutdown sites. Large component removals during reactor decommissioning provided an important source of information in developing Table S-1. At almost all of the shutdown sites, some refurbishment of the onsite or offsite transportation infrastructure would be required prior to shipping used nuclear fuel and GTCC low-level radioactive waste from the sites.

Table S-1. Summary of Transportation Mode Options for Shipments from Shutdown Sites

\begin{tabular}{|c|c|c|c|}
\hline Site & $\begin{array}{l}\text { Primary } \\
\text { Mode }\end{array}$ & $\begin{array}{l}\text { Secondary } \\
\text { Mode }\end{array}$ & Comments \\
\hline Maine Yankee & Direct rail & Barge to rail & $\begin{array}{l}\text { The condition of the onsite rail spur and Maine Eastern } \\
\text { Railroad would need to be verified. }\end{array}$ \\
\hline Yankee Rowe & $\begin{array}{l}\text { Heavy haul } \\
\text { truck to rail }\end{array}$ & - & $\begin{array}{l}\text { The heavy haul would be } 7.5 \text { miles to the east portal of } \\
\text { the Hoosac Tunnel. }\end{array}$ \\
\hline $\begin{array}{l}\text { Connecticut } \\
\text { Yankee }\end{array}$ & Barge to rail & $\begin{array}{l}\text { Heavy haul } \\
\text { truck to rail }\end{array}$ & $\begin{array}{l}\text { The barge canal would probably have to be dredged } \\
\text { before use. }\end{array}$ \\
\hline $\begin{array}{l}\text { Humboldt } \\
\text { Bay }\end{array}$ & Barge to rail & $\begin{array}{l}\text { Heavy haul } \\
\text { truck to rail }\end{array}$ & $\begin{array}{l}\text { The condition of the Fields Landing Terminal would need } \\
\text { to be verified. The heavy haul distance would be over } \\
160 \text { miles. }\end{array}$ \\
\hline $\begin{array}{l}\text { Big Rock } \\
\text { Point }\end{array}$ & $\begin{array}{l}\text { Heavy haul } \\
\text { truck to rail }\end{array}$ & Barge to rail & $\begin{array}{l}\text { The heavy haul would probably be about } 52 \text { miles to } \\
\text { Gaylord, Michigan. A shorter heavy haul of } 13 \text { miles to } \\
\text { Petoskey, Michigan may be possible. }\end{array}$ \\
\hline Rancho Seco & Direct rail & - & The rail spur would need to be refurbished. \\
\hline Trojan & Direct rail & Barge to rail & The onsite rail spur would need to be refurbished. \\
\hline La Crosse & Direct rail & Barge to rail & The onsite rail spur would need to be refurbished. \\
\hline Zion & Direct rail & Barge to rail & $\begin{array}{l}\text { The rail spur is being refurbished to support reactor } \\
\text { decommissioning waste shipments. }\end{array}$ \\
\hline
\end{tabular}

The actions necessary to prepare for and remove the used nuclear fuel and GTCC low-level radioactive waste from the shutdown sites are listed as tasks in Table S-2. Based on these tasks, the characteristics of the sites' inventories of used nuclear fuel and GTCC low-level radioactive waste, the onsite conditions, and the near-site transportation infrastructure and experience, time sequences of activities and time durations were developed to prepare for and remove the used nuclear fuel and GTCC low-level radioactive waste from a single shutdown site, from three shutdown sites located close to each other, and from all nine shutdown sites. Figure S-1 presents the ranges in the estimates of time durations for the single-shutdown site and three-shutdown site scenarios. These estimates were based on optimistic and conservative estimates of time durations for tasks, and on varying numbers of available transportation casks, which combine to yield the upper and lower estimates in Figure S-1. 
Table S-2. Activities to Prepare for and Remove Used Nuclear Fuel from Shutdown Sites

\begin{tabular}{|c|c|}
\hline Task & Task Activity Description \\
\hline \multicolumn{2}{|c|}{ Programmatic Activities to Prepare for Transport Operations from a Shutdown Site } \\
\hline $\begin{array}{l}1-\text { Assemble Project } \\
\text { Organization }\end{array}$ & $\begin{array}{l}\text { Assemble management teams, identify shutdown site existing infrastructure, } \\
\text { constraints, and transportation resource needs and develop interface } \\
\text { procedures. }\end{array}$ \\
\hline $\begin{array}{l}2 \text { - Acquire Casks, } \\
\text { Railcars, Ancillary } \\
\text { Equipment and Transport } \\
\text { Services }\end{array}$ & $\begin{array}{l}\text { Develop specifications, solicit bids, issue contracts, and initiate preparations } \\
\text { for shipping campaigns. Includes procurement of transportation casks and } \\
\text { revisions to certificates of compliance as may be needed, procurement of } \\
\text { AAR Standard S-2043 railcars, and procurement of offsite transportation } \\
\text { services. }\end{array}$ \\
\hline $\begin{array}{l}3 \text { - Conduct Preliminary } \\
\text { Logistics Analysis and } \\
\text { Planning }\end{array}$ & $\begin{array}{l}\text { Determine fleet size, transport requirements, and modes of transport for } \\
\text { shutdown site. }\end{array}$ \\
\hline $\begin{array}{l}4 \text { - Coordinate with } \\
\text { Stakeholders }\end{array}$ & $\begin{array}{l}\text { Assess and select routes and modes of transport and to support training of } \\
\text { transportation emergency response personnel. }\end{array}$ \\
\hline $\begin{array}{l}5 \text { - Develop Campaign } \\
\text { Plans }\end{array}$ & $\begin{array}{l}\text { Develop plans, policies, and procedures for at-site operational interfaces } \\
\text { and acceptance, support operations, and in-transit security operations. }\end{array}$ \\
\hline \multicolumn{2}{|c|}{ Operational Activities to Prepare, Accept, and Transport from a Shutdown Site } \\
\hline $\begin{array}{l}6-\text { Conduct Readiness } \\
\text { Activities }\end{array}$ & $\begin{array}{l}\text { Assemble and train at-site operations interface team and shutdown site } \\
\text { workers. Includes readiness reviews, table-top exercises and dry-run } \\
\text { operations. }\end{array}$ \\
\hline $\begin{array}{l}7 \text { - Load for Offsite } \\
\text { Transport }\end{array}$ & Load and prepare casks and place on transporters for offsite transportation. \\
\hline $\begin{array}{l}8 \text { - Accept for Offsite } \\
\text { Transport }\end{array}$ & Accept loaded casks on transporters for offsite transportation. \\
\hline 9 - Transport & Ship shutdown site casks. \\
\hline
\end{tabular}

AAR = Association of American Railroads

For a single shutdown site, the estimated time to prepare for and remove the used nuclear fuel and GTCC low-level radioactive waste ranged from 6.2 to 11.2 years. For the three shutdown sites scenario, the estimated time to prepare for and remove the used nuclear fuel and GTCC low-level radioactive waste ranged from 7.7 to 16.8 years. Figure S-2 presents the representative durations and sequence of activities to prepare for and remove all used nuclear fuel and GTCC low-level radioactive waste from the nine shutdown sites. In Figure S-2 the cumulative duration of 11.5 to 14.5 years to prepare for and remove all used nuclear fuel and GTCC low-level radioactive waste from the nine shutdown sites includes the schedule uncertainty associated with procurement of casks and railcars and coordination of shipping campaigns.

The estimated durations presented in Figures S-1 and S-2 were most affected by the time required to load and transport the used nuclear fuel and GTCC low-level radioactive waste; procure casks, components, and campaign kits; and the time required to procure railcars that meet Association of American Railroads (AAR) Standard S-2043 (2008). While the latter two activities could take place in parallel, they still represent a significant fraction of the time it would take to prepare for and remove the used nuclear fuel and GTCC low-level radioactive waste from the shutdown sites. In addition, project activities that would precede shipments 
would require about the same amount of time for the case where shipments were assumed to be made from only one shutdown site as for the case where coordinated shipments were assumed to be made from three shutdown sites. However, the amount of effort and resources that would be required would differ for these two cases. For example, to ship from the three shutdown sites would require acquisition of two kinds of transportation casks (NAC-UMS UTC and NAC-STC) and the preparations and staffing to interact with the operators of three sites. There would be benefits from serving more than one site in that the protocols, procedures, and operational interfaces would be similar among the sites. Also, the acquisition of additional railcars would not be expected to require substantially greater amount of effort by the U.S. Department of Energy (DOE) or other management and disposition organization after AAR certification was received on the railcar designs. Last, because the three sites were located in the same geographical region of the United States, interactions between DOE or other management and disposition organization and state, tribal, and local authorities would be facilitated and could be coordinated to limit requirements for resources.

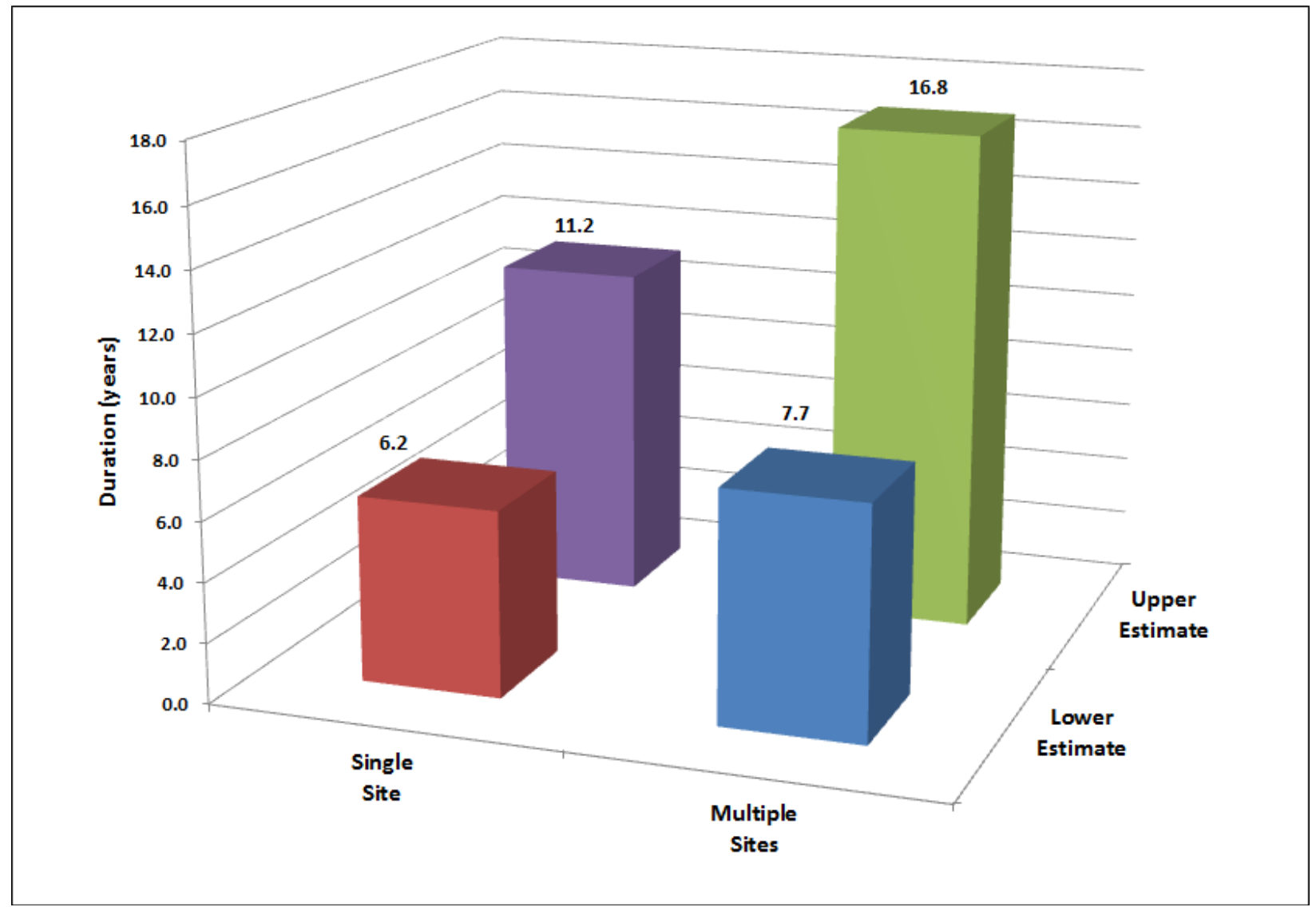

Figure S-1. Estimated Time Durations to Prepare for and Remove Used Nuclear Fuel and GTCC Low-Level Radioactive Waste from a Single Shutdown Site and Three Shutdown Sites 


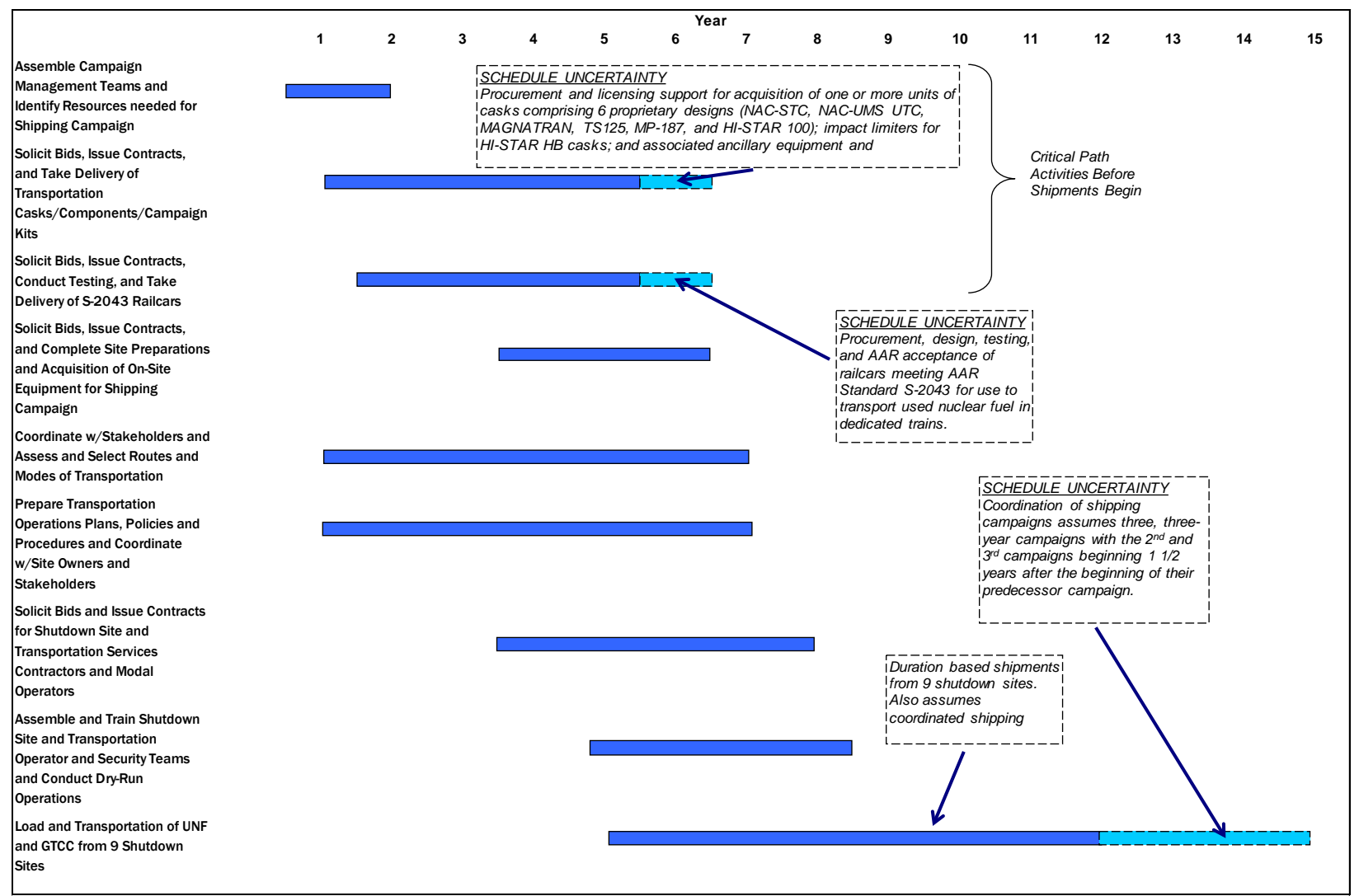

Figure S-2. Estimated Durations of Key Activities to Prepare for and Remove Used Nuclear Fuel and GTCC Low-Level Radioactive Waste from Nine Shutdown Sites

Similarly, the project activities that would precede shipments from all nine shutdown sites would require only a slightly greater amount of time than that that would be required for three shutdown sites. This assumes that project resources (personnel, funding, and functions such as procurement and quality assurance) would be adequate to support concurrent acquisitions of transportation casks and associated components that would include several units of each of the seven transportation casks that would be used at the shutdown sites-the NAC-STC, NAC-UMS UTC, MP187, TS-125, HI-STAR 100, HI-STAR HB, and MAGNATRAN; and to acquire and certify the fleet of cask, buffer, and escort rail cars that would be needed. It also assumes that there would be flexibility in making acquisitions such as limited constraints on procuring casks and associated components from non-domestic suppliers.

Also, assuming that project resources (including the number of cask, buffer, and escort rail cars; the staff needed to conduct and support shipping operations; and funding) are sufficient, shipment activities could be conducted concurrently from several of the shutdown sites. Based on discussions with managers at the Maine Yankee, Yankee Rowe, and Connecticut Yankee sites; assumptions regarding integrating the schedules for shipments from all nine shutdown sites; and assumptions regarding the project resources that would be made available, it is estimated that shipment operations to remove stranded used nuclear fuel from the shutdown sites could be completed in about 5 years. The relatively low rate of shipments (about 50 casks per 
year) would be principally the consequence of practical limits on the numbers of each type of cask that would be placed into service (assumed to be between two and five of each type of cask), the estimate that a cask would, on average, be used five or fewer times in a year, and the fact that interchangeable use of the seven different transportation casks among the nine shutdown sites would be limited.

As part of this preliminary evaluation, three shutdown sites were visited: Maine Yankee, Yankee Rowe, and Connecticut Yankee. In order to confirm the information in this report and to refine the estimates of activities and task durations, the authors recommend that the six remaining shutdown sites (Humboldt Bay, Big Rock Point, Rancho Seco, Trojan, La Crosse, and Zion) be visited.

The estimates of durations for project tasks presented here are preliminary and depend on the many identified assumptions. Consequently, in preparing a comprehensive project plan to prepare for and remove used nuclear fuel from the nine shutdown sites it will be necessary to refine the estimates using improved information regarding each of the sites and their near-site transportation infrastructure, and using methods that will allow managers to gauge the importance of assumptions and project considerations. In this regard, it is recommended that DOE use a quantitative risk analysis tool such as Primavera Risk Analysis (formerly known as Pertmaster) in conjunction with a scheduling tool such as Primavera P6 to provide estimates of project risks and opportunities. Such quantitative analyses would support estimating, managing, and funding of contingencies, and would increase confidence that the project would be successfully executed. Risk-informed estimates would also allow the project's managers to anticipate time and funding resources, and alternative courses of action that might be needed to effectively respond to changing circumstances.

DOE should also take advantage of improved information regarding loading and transportation of used nuclear fuel from the nine shutdown sites to refine the data used by the DOE Transportation Operations Model (TOM) to evaluate optimizations that may be possible in acquiring and using transportation resources. TOM could also be used to conduct sensitivity analyses and identify important gaps in information that could be filled with additional data collected from the shutdown sites. Information developed using TOM could also be used in case studies conducted using the quantitative analysis tools discussed above. 


\section{CONTENTS}

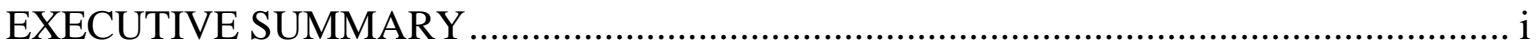

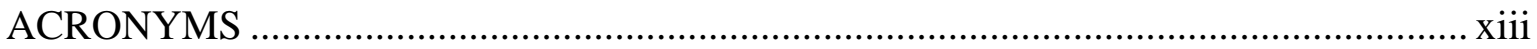

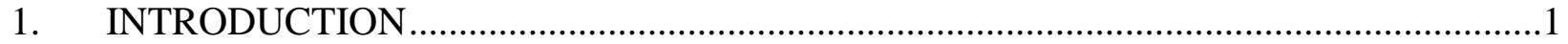

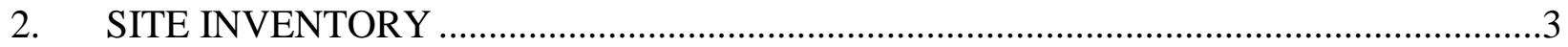

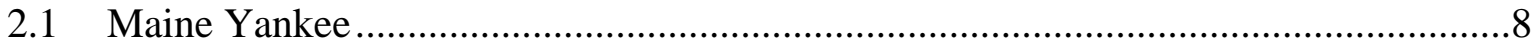

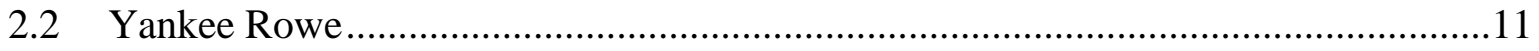

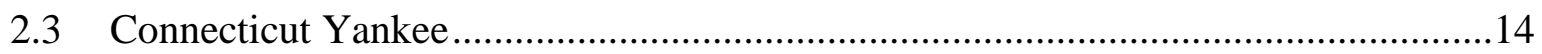

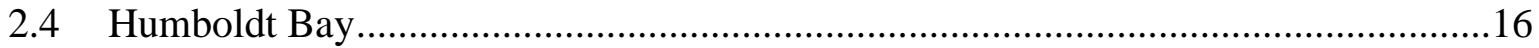

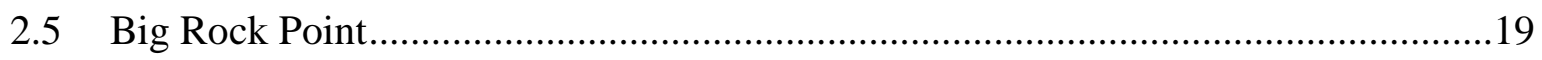

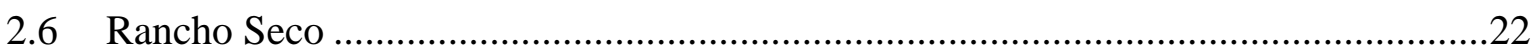

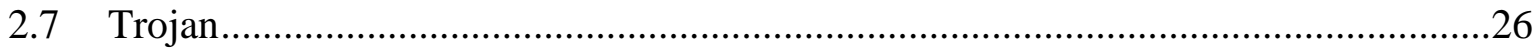

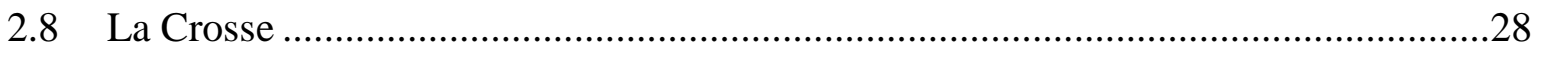

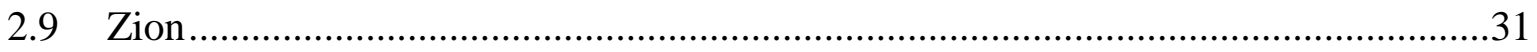

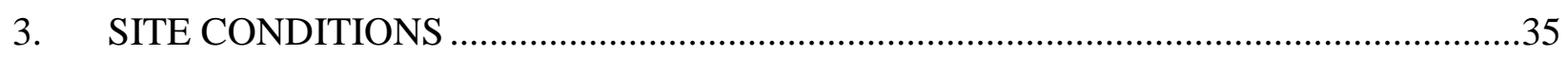

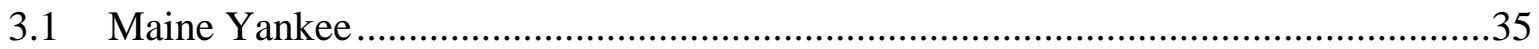

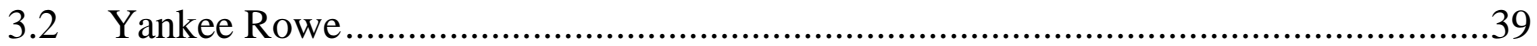

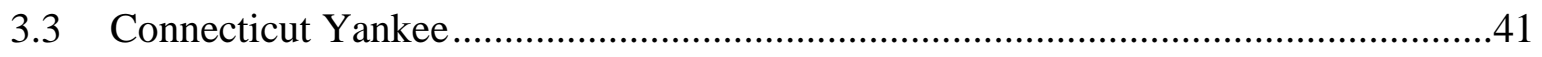

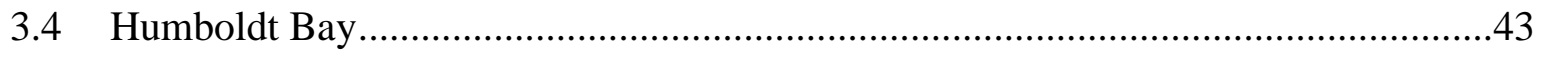

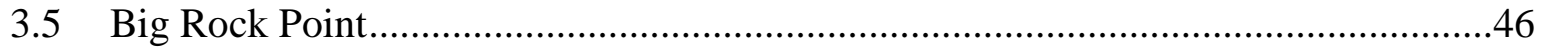

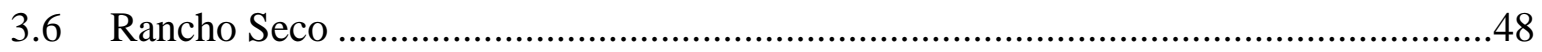

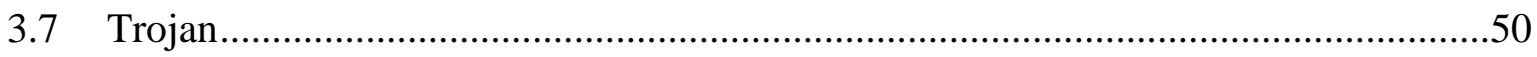

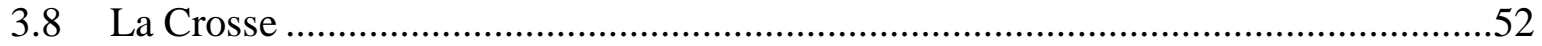

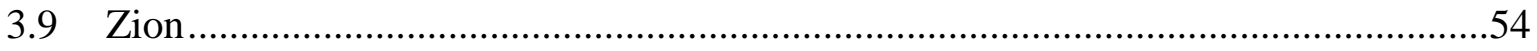

4. NEAR-SITE TRANSPORTATION INFRASTRUCTURE AND EXPERIENCE ............57

4.1 Overview of Requirements for Offsite Transportation Infrastructure .......................57

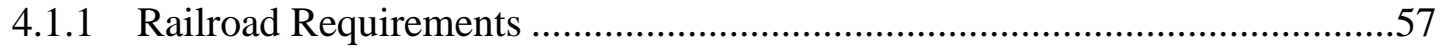

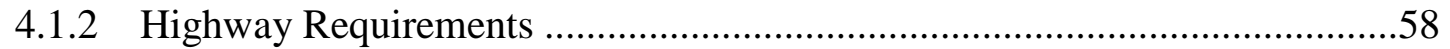

4.1.3 Navigable Waterway Requirements ....................................................60

4.2 Offsite Transportation Experience, Infrastructure, and Scenarios for

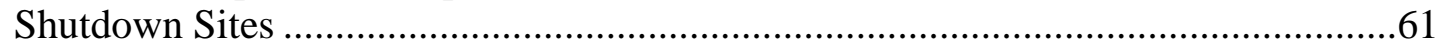

4.2.1 Direct Rail Transport from Shutdown Sites ................................................61

4.2.2 Heavy Haul Truck from Shutdown Sites to Railhead ...................................67

4.2.3 Barge Transport from Shutdown Sites to Port or Railhead ............................82

4.3 Summary of Gaps in Information Regarding Offsite Transportation Infrastructure for Nine Shutdown Sites 


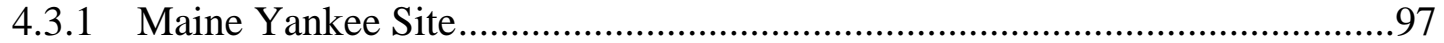

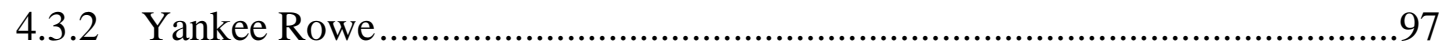

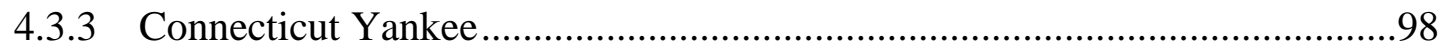

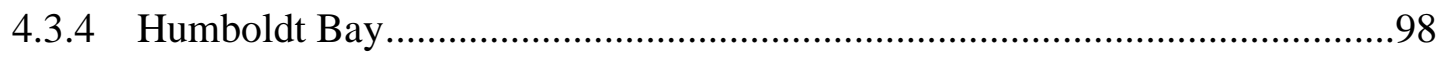

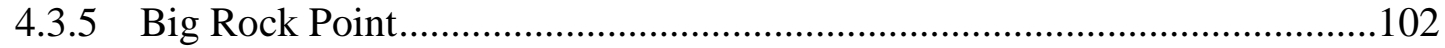

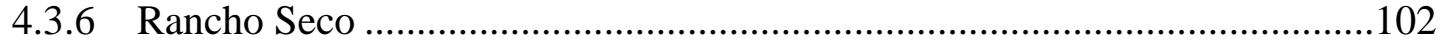

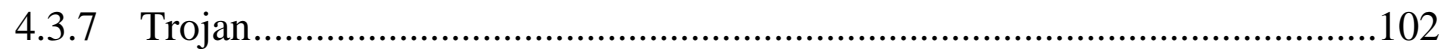

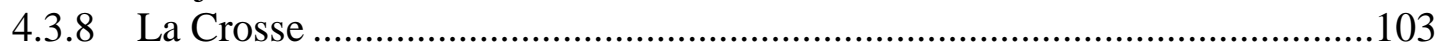

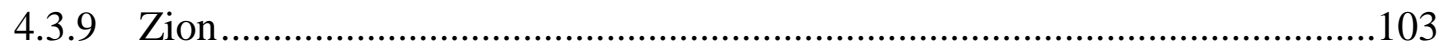

5. ACTIONS NECESSARY TO REMOVE USED NUCLEAR FUEL FROM

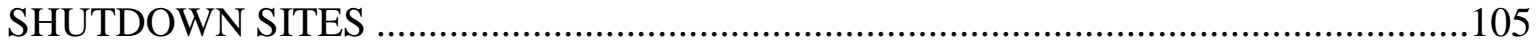

5.1 Programmatic Activities to Prepare for Transport Operations from a

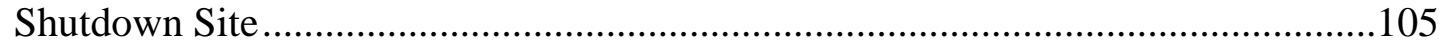

5.1.1 Task 1 - Assemble Project Organization..................................................106

5.1.2 Task 2 - Acquire Casks, Rail Cars, Ancillary Equipment, and Transport Services .................................................................................107

5.1.3 Task 3 - Conduct Preliminary Logistics Analysis and Planning ..................108

5.1.4 Task 4 - Coordinate with Stakeholders .......................................................109

5.1.5 Task 5 - Develop Campaign Plans ........................................................110

5.2 Operational Activities to Prepare, Accept, and Transport from a Shutdown

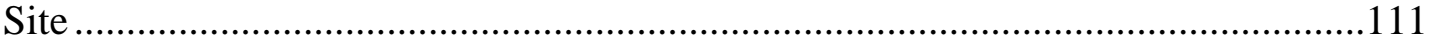

5.2.1 Task 6 - Conduct Readiness Activities ......................................................111

5.2.2 Task 7 - Load for Offsite Transport ........................................................... 112

5.2.3 Task 8 - Accept for Offsite Transportation ..............................................113

5.2.4 Task 9 - Transport ......................................................................113

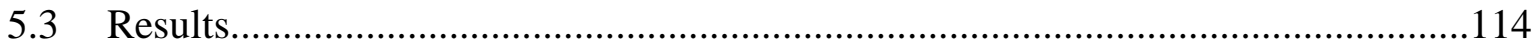

6. CONCLUSIONS AND RECOMMENDATIONS .......................................................127

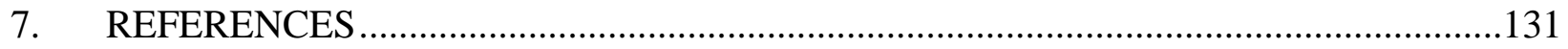

APPENDIX A. U.S. Nuclear Regulatory Commission Certificates of Compliance ..................137 


\section{TABLES}

S-1. Summary of Transportation Mode Options for Shipments from Shutdown Sites ................ ii

S-2. Activities to Prepare for and Remove Used Nuclear Fuel from Shutdown Sites................. iii

2-1. Characteristics of Shutdown Site Reactors ${ }^{\mathrm{a}}$.................................................................. 3

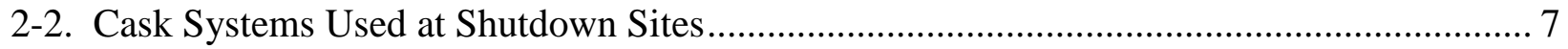

4-1. Alternative Railheads for Humboldt Bay .................................................................... 99

5-1. Activities to Prepare for and Remove Used Nuclear Fuel from Shutdown Sites.............. 105

6-1. Summary of Transportation Mode Options for Shipments from Shutdown Sites ............. 128

A-1. Transportation Casks Licensed to Transport Used Nuclear Fuel from the Shutdown

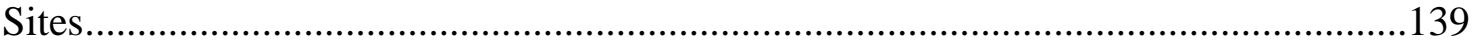

A-2. General Licensed Storage Systems Used at the Shutdown Sites....................................139

\section{FIGURES}

S-1. Estimated Time Durations to Prepare for and Remove Used Nuclear Fuel and GTCC LowLevel Radioactive Waste from a Single Shutdown Site and Three Shutdown Sites...... iv

S-2. Estimated Durations of Key Activities to Prepare for and Remove Used Nuclear

Fuel and GTCC Low-Level Radioactive Waste from Nine Shutdown Sites ................. v

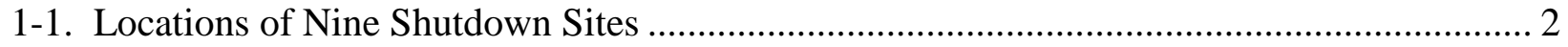

2-1. Number of Canisters at Nine Shutdown Sites ........................................................... 4

2-2. Number of Assemblies by Cladding Type at Nine Shutdown Sites (EIA 2002) ................. 5

2-3. Metric Tons Heavy Metal by Cladding Type at Nine Shutdown Sites (EIA 2002).............. 6

2-4. Maine Yankee Independent Spent Fuel Storage Installation............................................ 9

2-5. Maine Yankee Number of Assemblies versus Discharge Year (EIA 2002) ...................... 10

2-6. Maine Yankee Number of Assemblies versus Burnup (EIA 2002) ................................. 10

2-7. Yankee Rowe Independent Spent Fuel Storage Installation ........................................... 12

2-8. Yankee Rowe Number of Assemblies versus Discharge Year (EIA 2002) ....................... 13

2-9. Yankee Rowe Number of Assemblies versus Burnup (EIA 2002) .................................. 13

2-10. Connecticut Yankee Independent Spent Fuel Storage Installation ................................ 14

2-11. Connecticut Yankee Number of Assemblies versus Discharge Year (EIA 2002) ............. 15

2-12. Connecticut Yankee Number of Assemblies versus Burnup (EIA 2002) ........................ 16

2-13. Humboldt Bay Independent Spent Fuel Storage Installation ......................................... 17

2-14. Humboldt Bay Number of Assemblies versus Discharge Year (EIA 2002) .................... 18

2-15. Humboldt Bay Number of Assemblies versus Burnup (EIA 2002) ................................. 19 
2-16. Big Rock Point Independent Spent Fuel Storage Installation ............................................. 20

2-17. Big Rock Point Number of Assemblies versus Discharge Year (EIA 2002) ...................... 21

2-18. Big Rock Point Number of Assemblies versus Burnup (EIA 2002) ................................... 22

2-19. Rancho Seco Independent Spent Fuel Storage Installation ................................................. 23

2-20. Rancho Seco Number of Assemblies versus Discharge Year (EIA 2002)........................... 25

2-21. Rancho Seco Number of Assemblies versus Burnup (EIA 2002)....................................... 25

2-22. Trojan Independent Spent Fuel Storage Installation ........................................................... 26

2-23. Trojan Number of Assemblies versus Discharge Year (EIA 2002) .................................... 27

2-24. Trojan Number of Assemblies versus Burnup (EIA 2002) ............................................... 28

2-25. La Crosse Independent Spent Fuel Storage Installation.................................................... 29

2-26. La Crosse Number of Assemblies versus Discharge Year (EIA 2002)............................... 30

2-27. La Crosse Number of Assemblies versus Burnup (EIA 2002)........................................... 31

2-28. Zion Number of Assemblies versus Discharge Year (EIA 2002) ..................................... 32

2-29. Zion Number of Assemblies versus Burnup (EIA 2002) ................................................... 33

3-1. Aerial View of the Maine Yankee Site (Google 2012) ...................................................... 36

3-2. Onsite Railroad Spur at the Maine Yankee Site (Google 2012)............................................ 37

3-3. Paved-over Railroad Tracks at the Maine Yankee Site......................................................... 38

3-4. Barge Dock at the Maine Yankee Site................................................................................. 38

3-5. Aerial View of the Yankee Rowe Site (Google 2012) ........................................................ 40

3-6. Aerial View of the Connecticut Yankee Site (Google 2012) ................................................ 42

3-7. Barge Slip at the Connecticut Yankee Site............................................................................ 43

3-8. Aerial View of Humboldt Bay Site ................................................................................... 45

3-9. Aerial View of Big Rock Point Site (Google 2012).............................................................. 47

3-10. Aerial View of Rancho Seco Site (Google 2012)........................................................... 49

3-11. Aerial View of Trojan Site (Google 2012) ..................................................................... 51

3-12. Aerial View of La Crosse Site (Google 2012) ………...................................................... 53

3-13. Aerial View of Zion Site (Google 2012) ......................................................................... 55

3-14. Drawing of the Future Zion ISFSI (ZionSolutions 2012) …………………..................... 56

4-1. Rail Interface at Maine Yankee (Google 2012).................................................................... 62

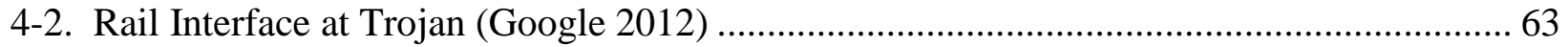

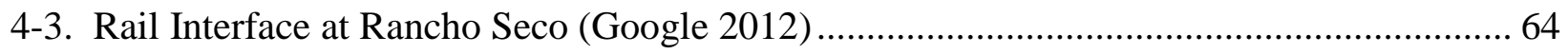

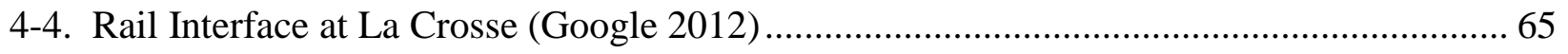




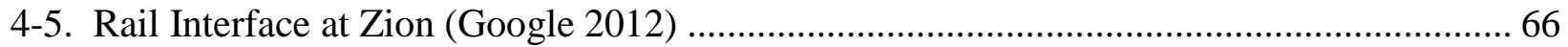

4-6. MP187 Cask Transported by Heavy Haul Truck ……........................................................ 68

4-7. HI-STAR HB Cask Transported by Heavy Haul Truck........................................................ 69

4-8. Yankee Rowe Reactor Pressure Vessel Being Transported by Heavy Haul Truck .............. 69

4-9. Yankee Rowe Reactor Pressure Vessel on Heavy Haul Truck Moving Under Power

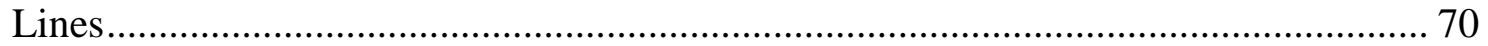

4-10. Rail Line at East Portal of the Hoosac Tunnel ...................................................................... 71

4-11. East Portal of the Hoosac Tunnel .................................................................................... 71

4-12. Yankee Rowe Reactor Pressure Vessel on Railcar .......................................................... 72

4-13. Yankee Rowe Reactor Pressure Vessel Heavy Haul Truck Route (Google 2012) ............. 73

4-14. Big Rock Point Reactor Pressure Vessel on Heavy Haul Truck ........................................... 74

4-15. Big Rock Point Reactor Pressure Vessel on Railcar .............................................................. 75

4-16. Big Rock Point Reactor Pressure Vessel Heavy and Steam Drum Haul Truck Routes (Google 2012) ............................................................................................. 76

4-17. Big Rock Point Steam Drum on Heavy Haul Truck ....................................................... 77

4-18. Big Rock Point Steam Drum on Railcar............................................................................ 77

4-19. Connecticut Yankee Pressurizer on Heavy Haul Truck Transporter ................................... 78

4-20. Connecticut Yankee Heavy Haul Truck Route (Google 2012)............................................ 79

4-21. Connecticut Yankee Pressurizer at Portland Railhead ............................................................. 80

4-22. Current Condition of Portland Railhead.......................................................................... 81

4-23. Zion Reactor Head on Heavy Haul Truck Transporter ..................................................... 82

4-24. Maine Yankee Reactor Pressure Vessel Being Loaded onto Barge ....................................... 84

4-25. Maine Yankee Reactor Pressure Vessel Being Transported on Barge................................. 84

4-26. Connecticut Yankee Reactor Pressure Vessel Being Loaded onto Barge............................ 85

4-27. Connecticut Yankee Reactor Pressure Vessel Being Transported on Barge....................... 86

4-28. Connecticut Yankee Reactor Pressure Vessel Being Transported on Barge in the

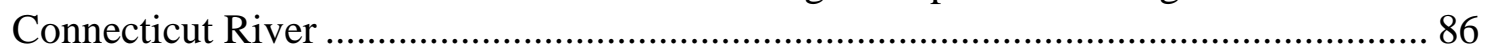

4-29. Trojan Steam Generator Being Loaded at Barge Slip ...................................................... 87

4-30. Trojan Reactor Pressure Vessel Being Transported by Barge .............................................. 87

4-31. Trojan Reactor Pressure Vessel Passing Through Locks on the Columbia River............... 88

4-32. Trojan Reactor Pressure Vessel Being Transported by Heavy Haul Truck ........................ 88

4-33. Big Rock Point ISFSI and Potential Barge Area (Google 2012) …………....................... 89

4-34. Humboldt Bay ISFSI and Fields Landing Terminal (Google 2012) .................................. 90 
4-35. Fields Landing Terminal (Google 2012) ............................................................................ 91

4-36. Wartsila Engine Being Loaded on a Barge ...................................................................... 92

4-37. Wartsila Engine on a Barge Being Towed to Fields Landing Terminal .............................. 93

4-38. Barge with Wartsila Engine Arriving at Fields Landing Terminal ..................................... 94

4-39. Wartsila Engine Being Unloaded at Fields Landing Terminal.............................................. 95

4-40. Wartsila Engine Being Transported by Heavy Haul Truck to Humboldt Bay Generating Station ..................................................................................................... 96

4-41. Heavy Haul Routes from Humboldt Bay ISFSI to Alternative Railheads (Google 2012)

5-1. Time Sequences of Activities and Estimated Durations to Prepare for and Remove Used Nuclear Fuel from a Single Shutdown Site Based on Five Casks and Conservative Task Durations.

5-2. Time Sequences of Activities and Estimated Durations to Prepare for and Remove Used Nuclear Fuel from a Single Shutdown Site Based on Five Casks and Optimistic Task Durations

5-3. Estimated Time Durations for Four Scenarios to Prepare for and Remove Used Nuclear Fuel from a Single Shutdown Site.

5-4. Time Sequences of Activities and Estimated Durations to Prepare for and Remove Used Nuclear Fuel from Multiple Shutdown Sites Based on Five NAC-UMS UTC Casks and Four NAC-STC Casks and Conservative Task Durations.

5-5. Time Sequences of Activities and Estimated Durations to Prepare for and Remove Used Nuclear Fuel from Multiple Shutdown Sites Based on Five NAC-UMS UTC Casks and Four NAC-STC Casks and Optimistic Task Durations. 122

5-6. Estimated Time Durations for Four Scenarios to Prepare for and Remove Used Nuclear Fuel from Multiple Shutdown Sites

5-7. Estimated Durations of Key Activities to Prepare for and Remove Used Nuclear Fuel from Nine Shutdown Sites 


\section{ACRONYMS}

AAR Association of American Railroads

AC\&T American Cranes \& Transport

ADAMS Agencywide Documents Access and Management System

BRC Blue Ribbon Commission on America’s Nuclear Future

BWR boiling water reactor

CY Connecticut Yankee

DOE U.S. Department of Energy

DSI DeskMap Systems, Inc.

EIA Energy Information Agency

EPRI Electric Power Research Institute

FC-DSC fuel with control component dry shielded canister

FF-DSC failed fuel dry shielded canister

FO-DSC fuel only dry shielded canister

GWd/MTHM gigawatt-day per metric ton heavy metal

GTCC greater-than-Class C

HBHRCD Humboldt Bay Harbor, Recreation \& Conservation District

$\begin{array}{ll}\text { IAEA } & \begin{array}{l}\text { International Atomic Energy Agency } \\ \text { independent spent fuel storage installation }\end{array} \\ \text { MPC } & \begin{array}{l}\text { multipurpose canister } \\ \text { metric tons heavy metal } \\ \text { megawatt electric } \\ \text { MWe } \\ \text { MWt }\end{array} \\ \text { megawatt thermal } \\ \text { PG\&E } & \text { U.S. Nuclear Regulatory Commission } \\ \text { PWR } & \begin{array}{l}\text { Pacific Gas and Electric Company } \\ \text { pressurized water reactor }\end{array} \\ \text { QA } & \text { quality assurance } \\ \text { STB } & \text { Surface Transportation Board } \\ \text { STC } & \text { storage transport cask } \\ \text { TN } & \text { Transnuclear, Inc. } \\ \text { TOM } & \text { Transportation Operations Model }\end{array}$


Nuclear Fuels Storage and Transportation Planning Project A Preliminary Evaluation of Removing Used Nuclear Fuel From Nine Shutdown Sites

TOPO Transportation Operations Project Office

TSC Transportable Storage Canister

USACE U.S. Army Corps of Engineers

UTC Universal Transport Cask 


\section{NUCLEAR FUELS STORAGE AND TRANSPORTATION PLANNING PROJECT \\ A Preliminary Evaluation of Removing Used Nuclear Fuel from Nine Shutdown Sites}

\section{INTRODUCTION}

The purpose of this report is to provide a preliminary evaluation of removing stranded used nuclear fuel from nine shutdown sites. Shutdown sites are defined as those commercial nuclear power reactor sites where the nuclear power reactors have been shut down and the site has been decommissioned or is undergoing decommissioning. The shutdown sites are Maine Yankee, Yankee Rowe, Connecticut Yankee, Humboldt Bay, Big Rock Point, Rancho Seco, Trojan, La Crosse, and Zion. The locations of these sites are shown in Figure 1-1. The material to be removed from the shutdown sites includes both the used nuclear fuel and the greater-thanClass C (GTCC) low-level radioactive waste that is stored, or will be stored, at the independent spent fuel storage installations (ISFSIs) at each one of the sites.

In addition to the nine shutdown sites evaluated in this report, Kewaunee, Crystal River, and Oyster Creek have announced that they will close (Dominion 2012, Duke Energy 2013, and Exelon 2010). Kewaunee is expected to cease power production on May 7, 2013 (Stoddard 2013), Crystal River has been shut down since 2009 and will be retired (Duke Energy 2013), and Oyster Creek will operate until 2019 (Exelon 2010). These additional sites will be evaluated in updates to this report.

In this report, the preliminary evaluation of removing the used nuclear fuel and GTCC low-level radioactive waste from the shutdown sites was divided in four components:

- characterization of the used nuclear fuel and GTCC low-level radioactive waste inventory at the shutdown sites

- an evaluation of the onsite transportation conditions at the shutdown sites

- an evaluation of the near-site transportation infrastructure and experience relevant to the shipping of transportation casks containing used nuclear fuel from the shutdown sites

- an evaluation of actions necessary to prepare for and remove used nuclear fuel and GTCC low-level radioactive waste from the shutdown sites.

These evaluations are contained in Sections 2 through 5. The evaluation of the near-site transportation infrastructure and experience at shutdown sites also includes an evaluation of the gaps in information regarding offsite transportation infrastructure for the shutdown sites. 
Section 5 also contains time sequences of activities and their durations developed from the lists of actions that are necessary to prepare for and remove used nuclear fuel and GTCC low-level radioactive waste from the shutdown sites. Total time durations for single-site scenarios and multiple-site scenarios are developed for conservative and optimistic estimates of the time durations for tasks, and assuming varying numbers of available casks. Representative durations and sequences of activities to prepare for and remove all used nuclear fuel and GTCC low-level radioactive waste from the nine shutdown sites are also presented, and include the schedule uncertainty associated with procurement of casks and railcars and coordination of shipping campaigns.

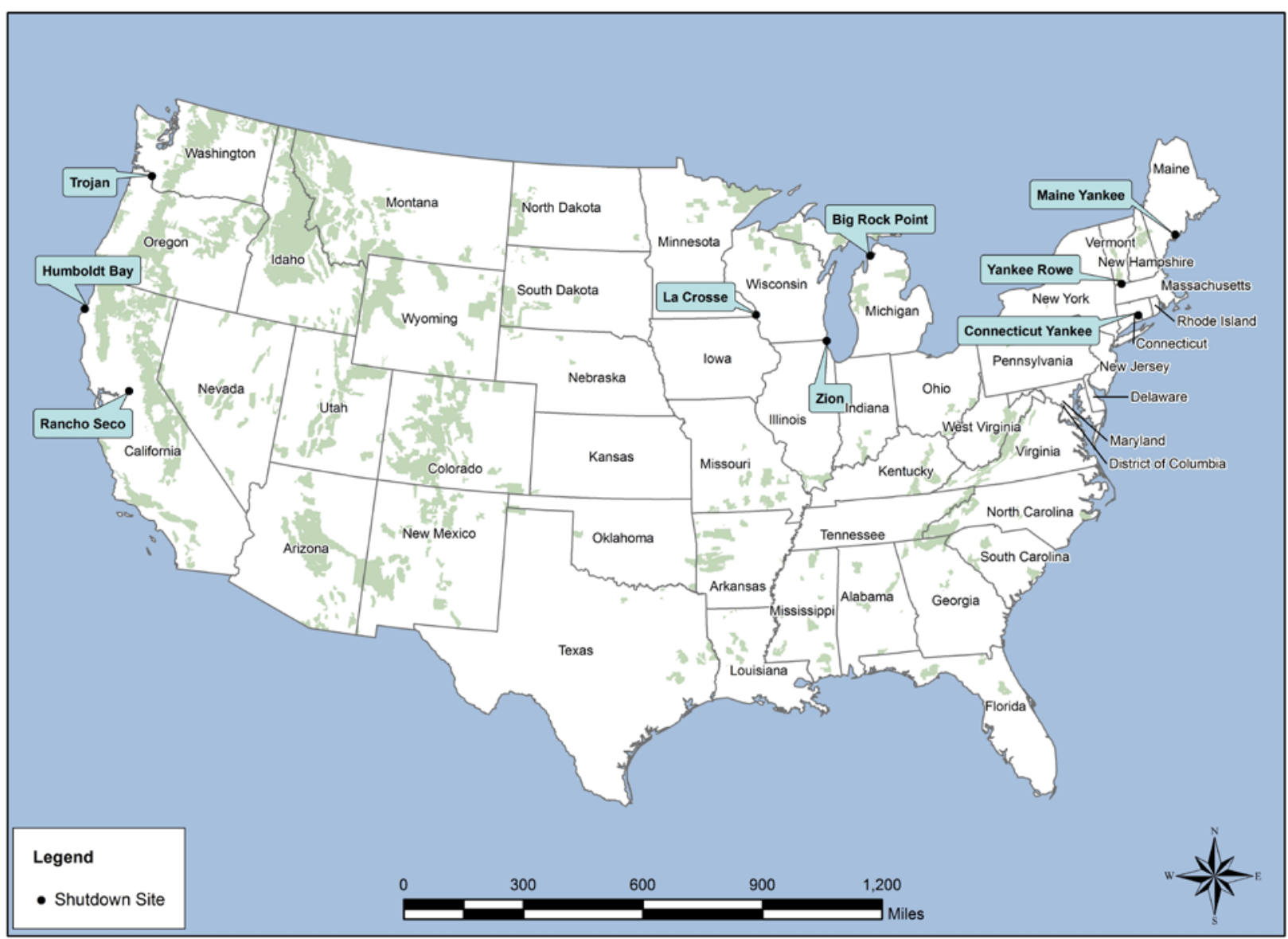

Figure 1-1. Locations of Nine Shutdown Sites 


\section{SITE INVENTORY}

This section describes the inventory of used nuclear fuel and GTCC low-level radioactive waste located at each of the nine shutdown sites. The primary sources for the information presented in this section are the RW-859 database (EIA 2002), industry sources such as StoreFUEL and SpentFUEL, and government sources such as the U.S. Nuclear Regulatory Commission (NRC).

Table 2-1 lists the characteristics of the commercial nuclear power reactors that operated at the nine shutdown sites. These reactors operated between the years 1961 and 1997. Three of the reactors (Humboldt Bay, Big Rock Point, and La Crosse) were boiling water reactors and six of the reactors were pressurized water reactors (Maine Yankee, Yankee Rowe, Connecticut Yankee, Rancho Seco, Trojan, and Zion 1 and 2). The licensed capacities for these reactors ranged from 165 to 3411 MWt (48 to 1130 MWe). Decommissioning has been completed for six of the sites and is ongoing at Humboldt Bay, La Crosse, and Zion. Maine Yankee, Yankee Rowe, Connecticut Yankee, Humboldt Bay, Big Rock Point, Rancho Seco, Trojan, and Zion chose DECON as their decommissioning alternative, which is defined by the NRC as a method of decommissioning in which structures, systems, and components that contain radioactive contamination are removed from a site and safely disposed of at a commercially operated lowlevel radioactive waste disposal facility or decontaminated to a level that permits the site to be released for unrestricted use shortly after it ceases operation (NRC 2012a). La Crosse has chosen SAFSTOR as their decommissioning alternative, which is defined by the NRC as a method of decommissioning in which a nuclear facility is placed and maintained in a safe condition that allows the facility to be subsequently decontaminated (deferred decontamination) to levels that permit release for unrestricted use (NRC 2012a).

Table 2-1. Characteristics of Shutdown Site Reactors ${ }^{a}$

\begin{tabular}{|c|c|c|c|c|c|}
\hline Site Location & $\begin{array}{l}\text { Reactor } \\
\text { Type }\end{array}$ & MWt & $\begin{array}{l}\text { MWe } \\
\text { (net) }\end{array}$ & $\begin{array}{l}\text { Operating } \\
\text { Period }^{\mathrm{b}}\end{array}$ & Current Status \\
\hline Maine Yankee, Wiscasset, Maine & PWR & 2700 & 860 & $1972-1996$ & DECON Completed \\
\hline $\begin{array}{l}\text { Yankee Rowe, Rowe, } \\
\text { Massachusetts }\end{array}$ & PWR & 600 & 167 & 1961-1991 & DECON Completed \\
\hline $\begin{array}{l}\text { Connecticut Yankee, Meriden, } \\
\text { Connecticut }\end{array}$ & PWR & 1825 & 560 & 1968-1996 & DECON Completed \\
\hline Humboldt Bay, Eureka, California & BWR & 200 & 63 & 1963-1976 & DECON in Progress \\
\hline $\begin{array}{l}\text { Big Rock Point, Charlevoix, } \\
\text { Michigan }\end{array}$ & BWR & 240 & 67 & 1963-1997 & DECON Completed \\
\hline Rancho Seco, Herald, California & PWR & 2772 & 913 & 1975-1989 & DECON in Progress \\
\hline Trojan, Rainer, Oregon & PWR & 3411 & 1130 & 1976-1992 & DECON Completed \\
\hline La Crosse, Genoa, Wisconsin & BWR & 165 & 48 & 1969-1987 & SAFSTOR \\
\hline Zion 1, Zion, Illinois & PWR & 3250 & 1040 & 1973-1997 & DECON in Progress \\
\hline Zion 2, Zion, Illinois & PWR & 3250 & 1040 & 1974-1996 & DECON in Progress \\
\hline
\end{tabular}

a. Sources: NRC (2012a) and IAEA (2012)

b. The operating period represents the date of commercial operation to the date of shutdown. $\mathrm{PWR}=$ pressurized water reactor $\mathrm{BWR}=$ boiling water reactor 
Figure 2-1 illustrates the number of canisters and type of storage canister containing used nuclear fuel and GTCC low-level radioactive waste that are stored or will be stored at each of the nine shutdown sites. The number of canisters stored at Maine Yankee, Yankee Rowe, Connecticut Yankee, Big Rock Point, Rancho Seco, and Trojan represent actual canisters in storage, while the number of canisters for Zion represents an estimate of the number of used nuclear fuel canisters that will be stored at the conclusion of canister loading. At Humboldt Bay, an additional canister containing GTCC low-level radioactive waste is expected to be loaded in spring 2013 (NRC 2012b). Additional canisters containing GTCC low-level radioactive waste could also be generated at La Crosse and Zion as decommissioning progresses. There are a total of 259 canisters in storage (actual plus estimated). The number of canisters ranges from 5 at La Crosse to 64 at Maine Yankee.

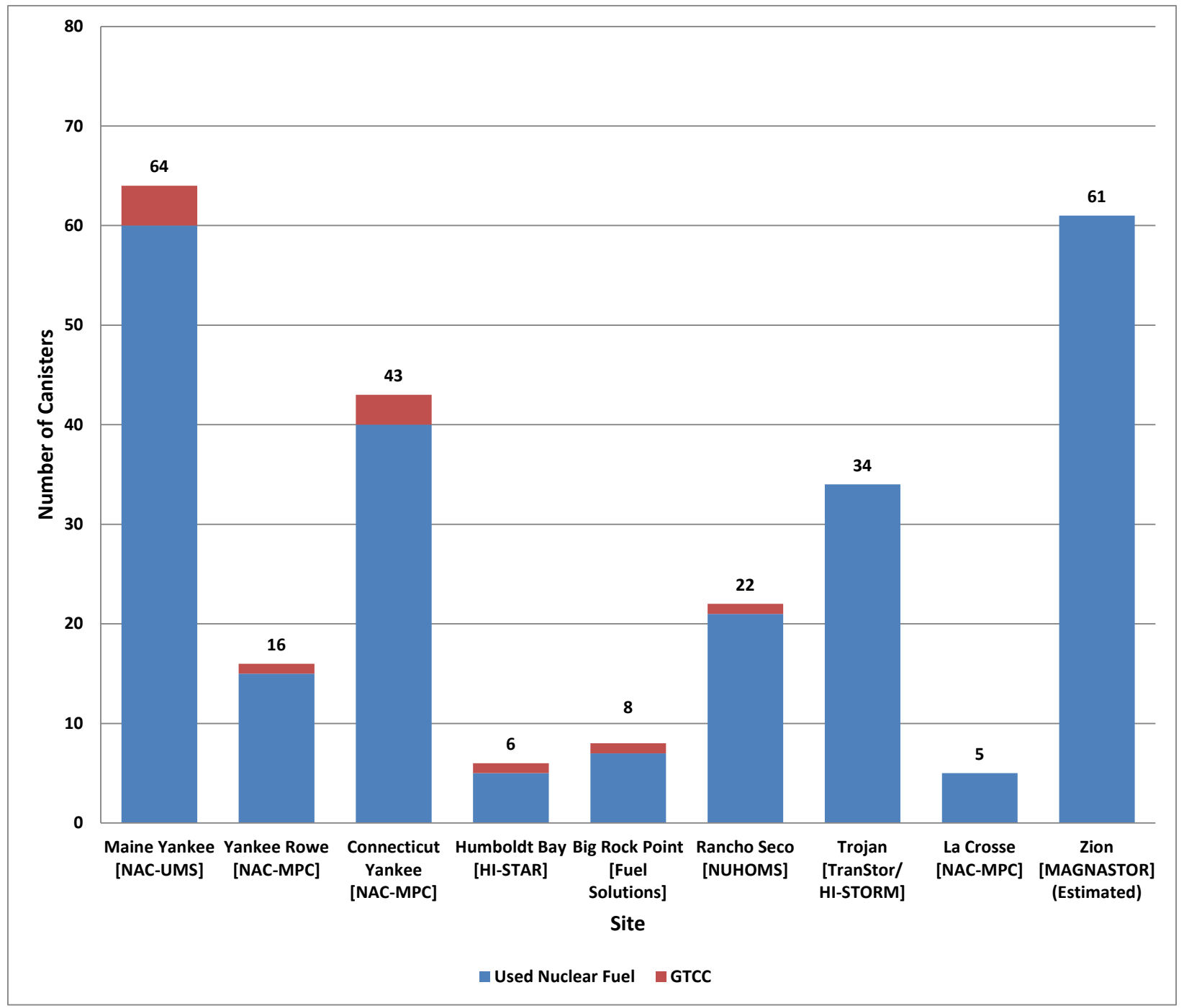

Figure 2-1. Number of Canisters at Nine Shutdown Sites 
Figure 2-2 illustrates the number of used nuclear fuel assemblies stored at each site. Because the reactors at the sites have been shut down, these quantities represent the actual number of used nuclear fuel assemblies that are stored or that must be stored at the sites. There are a total of 7649 used nuclear fuel assemblies present at the nine shutdown sites. These assemblies are composed of 6485 pressurized water reactor assemblies and 1164 boiling water reactor assemblies. The number of assemblies ranges from 333 at La Crosse to 2226 at Zion. The majority (6382) of used nuclear fuel assemblies are Zircaloy-clad; but Yankee Rowe, Connecticut Yankee, and La Crosse have 1267 stainless steel-clad used nuclear fuel assemblies in storage. Figure 2-3 illustrates the same information in terms of the metric tons of heavy metal stored at each site. A total of 2813.2 metric tons heavy metal (MTHM) of used nuclear fuel at the nine shutdown sites consists of 2688.3 MTHM of pressurized water reactor used nuclear fuel and 124.8 MTHM of boiling water reactor used nuclear fuel. The number of assemblies and MHTM of used nuclear fuel at each shutdown site were obtained from the RW-859 database (EIA 2002) and may not include material such as fuel debris and failed fuel rod containers that may also be present in the storage canisters at the shutdown sites.

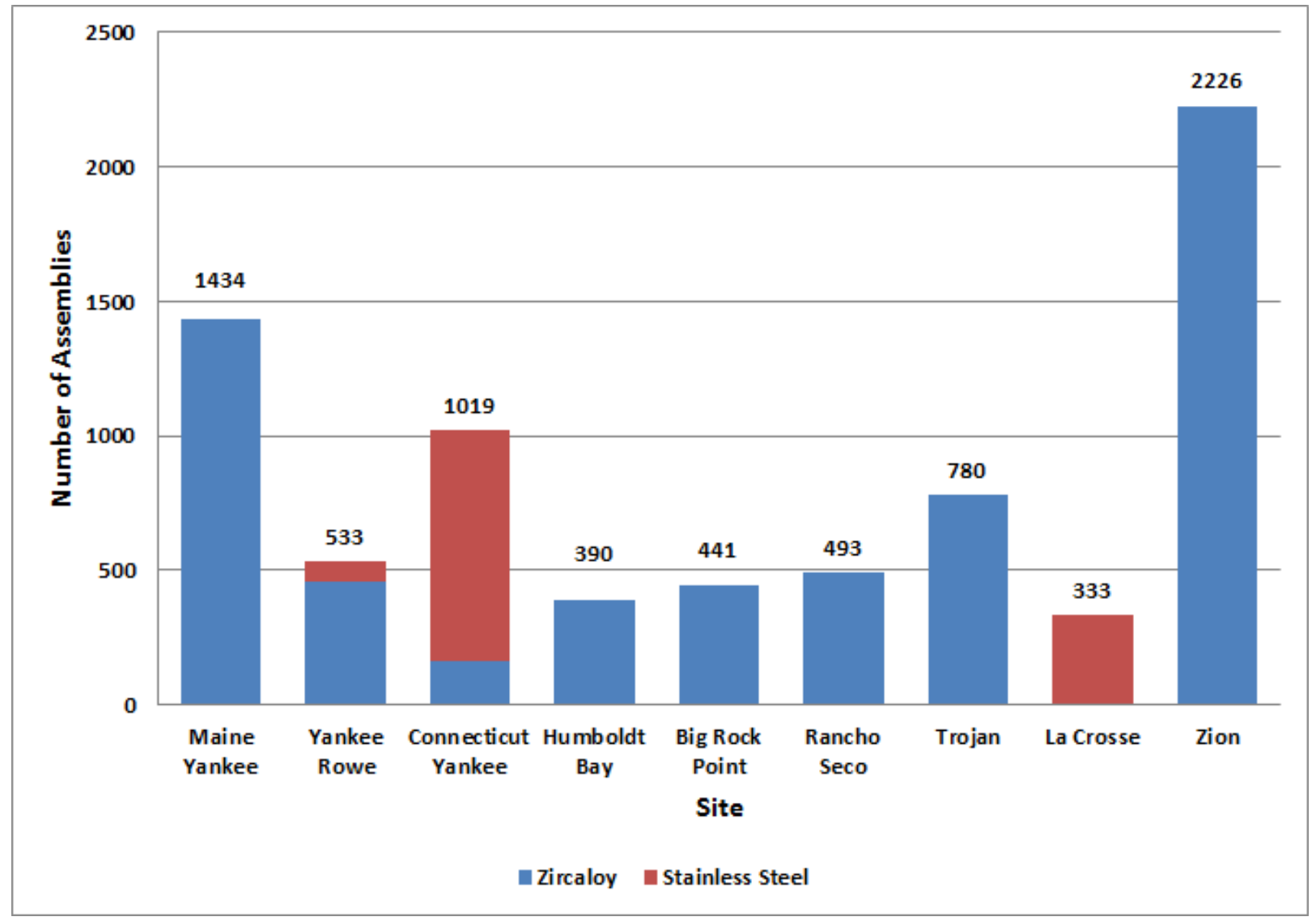

Figure 2-2. Number of Assemblies by Cladding Type at Nine Shutdown Sites (EIA 2002) 


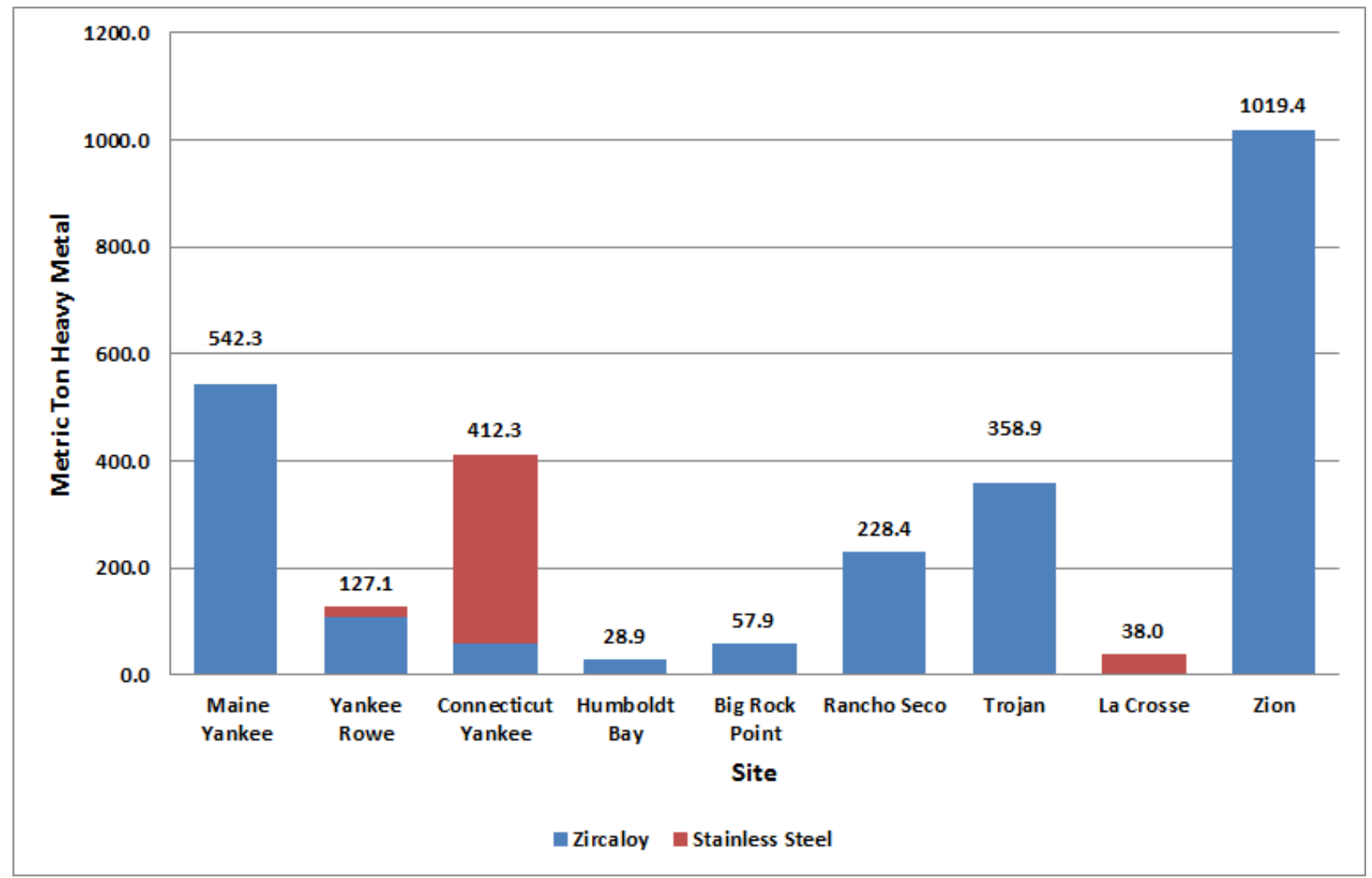

Figure 2-3. Metric Tons Heavy Metal by Cladding Type at Nine Shutdown Sites (EIA 2002)

Table 2-2 (Leduc 2012) lists the storage systems used at the nine shutdown sites and the corresponding transportation casks that are certified to ship the storage canisters containing used nuclear fuel and GTCC low-level radioactive waste at each of the sites. ${ }^{1}$ Out of the seven transportation cask designs listed in Table 2-2, only three types have been fabricated for U.S. use: the HI-STAR HB, the MP187, and the HI-STAR 100. The HI-STAR HB and MP187 can only be used to ship used nuclear fuel from the Humboldt Bay and Rancho Seco sites. The HI-STAR 100 casks that have been fabricated are already being used as storage casks at the Dresden and Hatch sites (Ux Consulting 2012). For the HI-STAR 100 casks to be used to ship used nuclear fuel from the Trojan site, they would need to be unloaded, their contents placed in other storage overpacks at the Dresden and Hatch sites, and the casks transported to the Trojan site. It would also be necessary to procure impact limiters for the HI-STAR 100 casks. The NAC-STC has been fabricated for foreign use, but not for use in the United States. Two NAC-STC transportation casks have been fabricated for use in China (Washington Nuclear Corporation 2003).

\footnotetext{
${ }^{1}$ Appendix A lists the docket number, certificate of compliance number issue date, certificate of compliance expiration date, amendment number, amendment effective date, and Agencywide Documents Access and Management System (ADAMS) accession number for the general licensed storage systems used at the shutdown sites, and also lists the docket number, package identification number, revision number, certificate of compliance expiration date, and ADAMS accession number for the transportation casks licensed to transport used nuclear fuel from the shutdown sites.
} 
Table 2-2. Cask Systems Used at Shutdown Sites

\begin{tabular}{|c|c|c|c|c|c|}
\hline Reactor Site & Type & $\begin{array}{l}\text { ISFSI Load } \\
\text { Dates }^{\mathrm{a}}\end{array}$ & Storage System /Canister(s) & Transport Cask Status & $\begin{array}{l}\text { Canisters } \\
\text { Fuel/GTCC }\end{array}$ \\
\hline $\begin{array}{l}\text { Big Rock } \\
\text { Point }\end{array}$ & BWR & $\begin{array}{l}12 / 2002- \\
03 / 2003\end{array}$ & $\begin{array}{l}\text { Fuel Solutions W150 Storage } \\
\text { Overpack/W74 Canister }\end{array}$ & $\begin{array}{l}\text { TS125 (Docket No. 71-9276) } \\
\text { Certificate expires 10/31/2017. } \\
\text { None fabricated. }\end{array}$ & $7 / 1$ \\
\hline $\begin{array}{l}\text { Connecticut } \\
\text { Yankee }\end{array}$ & PWR & $\begin{array}{l}05 / 2004- \\
03 / 2005\end{array}$ & $\begin{array}{l}\text { NAC-MPC/CY-MPC transportable storage } \\
\text { canister }\end{array}$ & $\begin{array}{l}\text { NAC-STC (Docket No. 71-9235) } \\
\text { Certificate expires 5/31/2014. } \\
\text { Foreign use versions fabricated. }\end{array}$ & $40 / 3$ \\
\hline Maine Yankee & PWR & $\begin{array}{l}08 / 2002- \\
03 / 2004\end{array}$ & NAC-UMS/transportable storage canister & $\begin{array}{l}\text { NAC-UMS UTC (Docket No. 71-9270) } \\
\text { Certificate expires 10/31/2017. } \\
\text { None fabricated }\end{array}$ & $60 / 4$ \\
\hline Yankee Rowe & PWR & $\begin{array}{l}06 / 2002- \\
06 / 2003\end{array}$ & $\begin{array}{l}\text { NAC-MPC/Yankee-MPC transportable } \\
\text { storage canister }\end{array}$ & $\begin{array}{l}\text { NAC-STC (Docket No. 71-9235) } \\
\text { Certificate expires 05/31/2014. } \\
\text { Foreign use versions fabricated. }\end{array}$ & $15 / 1$ \\
\hline Rancho Seco & PWR & $\begin{array}{l}04 / 2001- \\
08 / 2002\end{array}$ & $\begin{array}{l}\text { TN NUHOMS/FO-DSC, FC-DSC, and } \\
\text { FF-DSC }\end{array}$ & $\begin{array}{l}\text { NUHOMS MP187 (Docket No. 71-9255) } \\
\text { Certificate expires 11/30/2013. } \\
\text { One cask fabricated. No impact limiters. }\end{array}$ & $21 / 1$ \\
\hline Trojan & PWR & $\begin{array}{l}12 / 2002- \\
09 / 2003\end{array}$ & $\begin{array}{l}\text { TranStor Storage Overpack/Holtec MPC-24E } \\
\text { and MPC-24EF canisters }\end{array}$ & $\begin{array}{l}\text { HI-STAR } 100 \text { (Docket No. 71-9261) } \\
\text { Certificate expires 3/31/2014. } \\
\text { Units fabricated but dedicated to storage at } \\
\text { other sites. No impact limiters. }\end{array}$ & $34 / 0$ \\
\hline Humboldt Bay & BWR & $\begin{array}{l}08 / 2008- \\
12 / 2008\end{array}$ & Holtec HI-STAR HB/MPC-HB canister & $\begin{array}{l}\text { HI-STAR HB (Docket No. 71-9261) } \\
\text { Certificate expires 3/31/2014. } \\
\text { Fuel in canisters in fabricated casks. No } \\
\text { impact limiters. }\end{array}$ & $5 / 1^{\mathrm{b}}$ \\
\hline La Crosse & BWR & $\begin{array}{l}07 / 2012- \\
09 / 2012\end{array}$ & $\begin{array}{l}\text { NAC MPC-LACBWR/MPC-LACBWR } \\
\text { transportable storage canister }\end{array}$ & $\begin{array}{l}\text { NAC-STC (Docket No. 71-9235) } \\
\text { Certificate expires 5/31/2014. } \\
\text { Foreign use versions fabricated. }\end{array}$ & $5^{c}$ \\
\hline Zion 1 and 2 & PWR & $\begin{array}{l}\text { Planned } \\
2013\end{array}$ & NAC MAGNASTOR/TSC-37 canister & $\begin{array}{l}\text { NAC MAGNATRAN (Docket No. 71- } \\
\text { 9356) } \\
\text { Application for Certificate of Compliance } \\
\text { under review. None fabricated }\end{array}$ & $61^{\mathrm{c}, \mathrm{d}}$ \\
\hline
\end{tabular}

BWR= boiling water reactor, GTCC = greater-than-Class C, ISFSI = independent spent fuel storage installation, PWR= pressurized water reactor a. Dates represent the dates that the used nuclear fuel was transferred to the ISFSI.

b. One canister of GTCC low-level radioactive is expected to be loaded and transferred to the Humboldt Bay ISFSI in spring 2013 (NRC $2012 \mathrm{~b}$ ).

c. Additional canisters of GTCC low-level radioactive waste could be generated during decommissioning.

d. Estimated. 


\subsection{Maine Yankee}

Sixty canisters containing 1434 used nuclear fuel assemblies (542.3 MTHM) and 4 canisters of GTCC low-level radioactive waste are stored at Maine Yankee. Figure 2-4 shows the ISFSI at Maine Yankee. The storage system used at Maine Yankee is the NAC-UMS system (Docket No. 72-1015), which consists of a transportable storage canister, a vertical concrete storage cask, and a transfer cask. The transportable storage canister holds 24 pressurized water reactor used nuclear fuel assemblies. The fuel assemblies from Maine Yankee were loaded into transportable storage canisters from August 2002 through March 2004 (Leduc 2012). The fuel assemblies are Zircaloy-clad. The transportation cask that is licensed to transport the canisters containing this used nuclear fuel or GTCC low-level radioactive waste is the NAC-UMS Universal Transport Cask (UTC) Package (Docket No. 71-9270). No NAC-UMS UTC transportation casks have been fabricated either domestically or for use overseas.

Figure 2-5 illustrates the number of used nuclear fuel assemblies at Maine Yankee based on their discharge year. The oldest fuel was discharged in 1974 and the last fuel was discharged in 1996. The median discharge year of the fuel is 1984 .

Figure 2-6 illustrates the number of used nuclear fuel assemblies at Maine Yankee based on their burnup. The lowest burnup is 2.8 gigawatt-day per metric ton heavy metal (GWd/MTHM) and the highest burnup is $49.2 \mathrm{GWd} / \mathrm{MTHM}$. The median burnup is $32.1 \mathrm{GWd} / \mathrm{MTHM}$. Used nuclear fuel with a burnup greater than $45 \mathrm{GWd}$ /MTHM is termed as high burnup used nuclear fuel by the NRC. There are 90 of these high burnup used nuclear fuel assemblies at Maine Yankee. These high burnup used nuclear fuel assemblies were packaged in Maine Yankee Fuel Cans (i.e., damaged fuel cans) and were loaded in the four basket corner positions in the transportable storage canisters. Twenty-three transportable storage canisters containing high burnup used nuclear fuel are stored at Maine Yankee. 


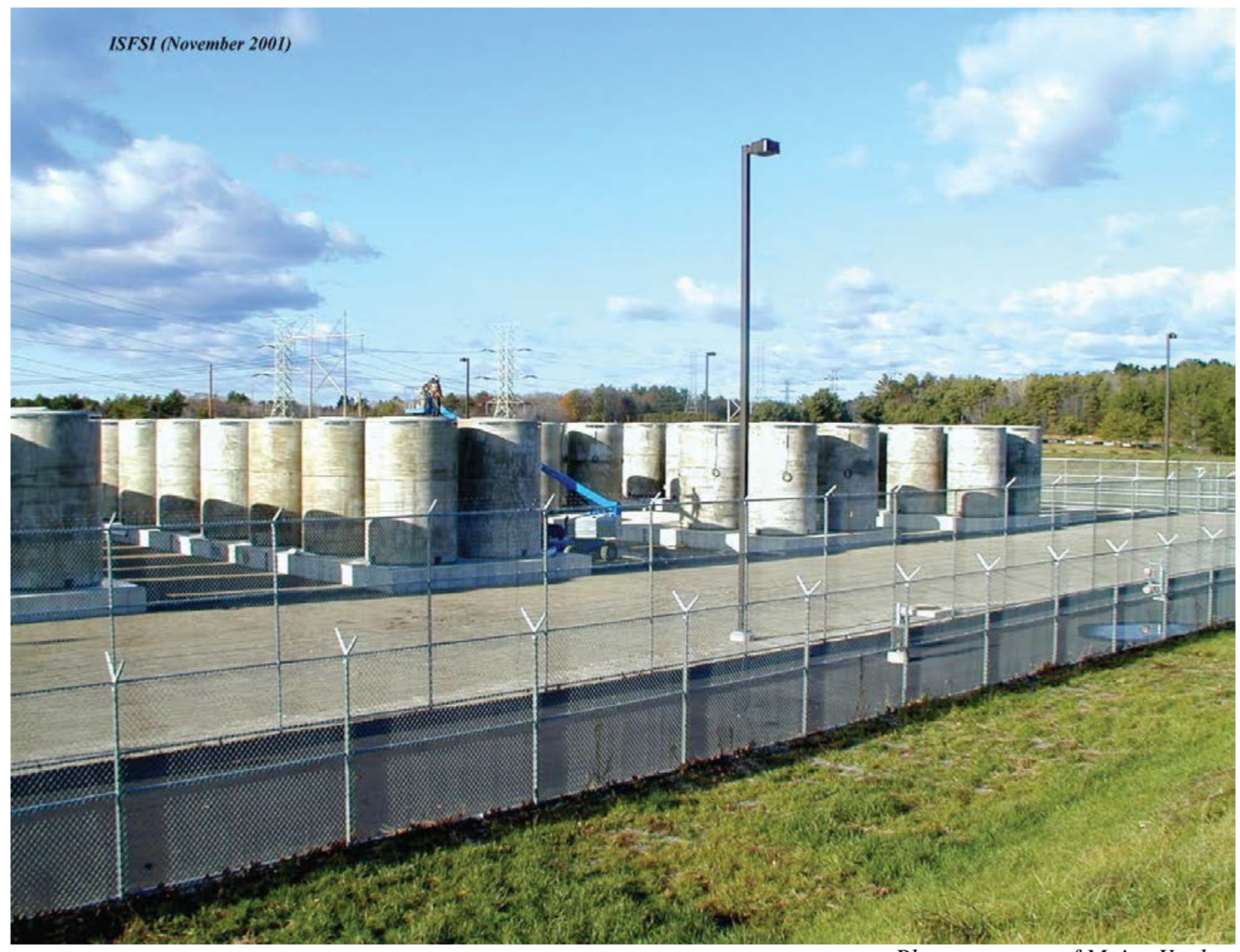

Photo courtesy of Maine Yankee

Figure 2-4. Maine Yankee Independent Spent Fuel Storage Installation 
Nuclear Fuels Storage and Transportation Planning Project A Preliminary Evaluation of Removing Used Nuclear Fuel From Nine Shutdown Sites

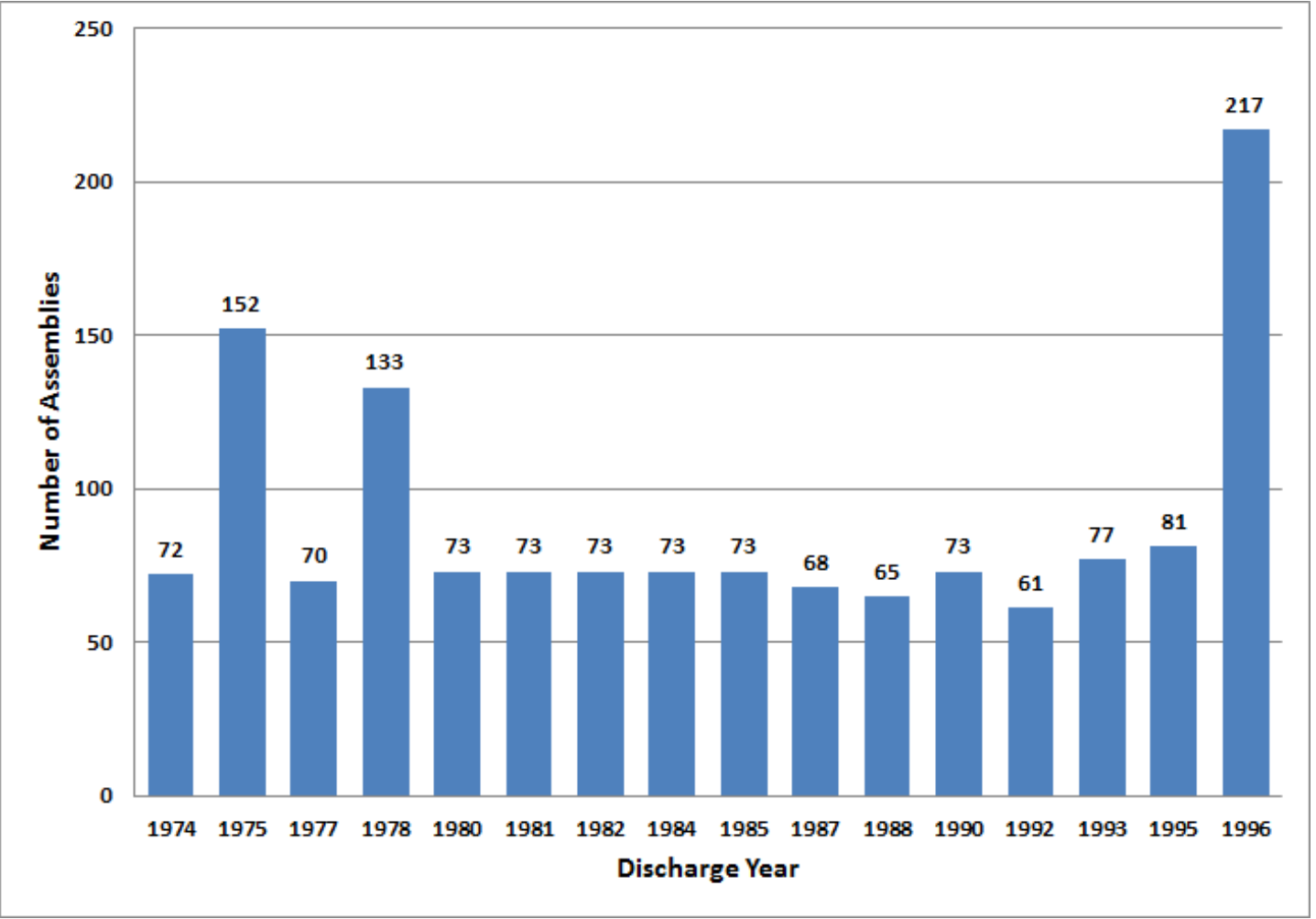

Figure 2-5. Maine Yankee Number of Assemblies versus Discharge Year (EIA 2002)

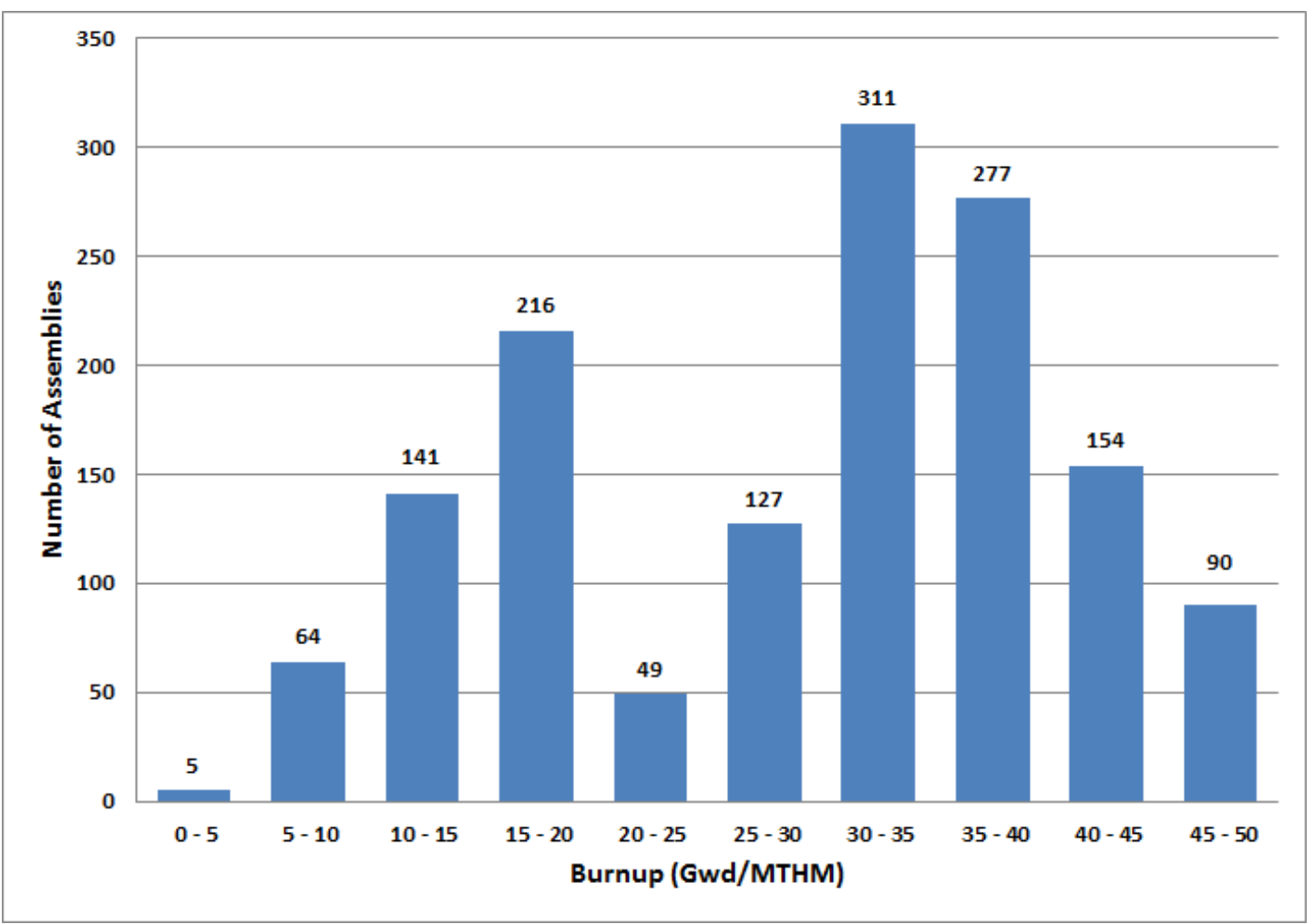

Figure 2-6. Maine Yankee Number of Assemblies versus Burnup (EIA 2002) 


\subsection{Yankee Rowe}

There are 15 canisters containing 533 used nuclear fuel assemblies (127.1 MTHM) and 1 canister of GTCC low-level radioactive waste stored at Yankee Rowe. Figure 2-7 shows the ISFSI at Yankee Rowe. The storage system used at Yankee Rowe is the NAC Multi-Purpose Canister system (NAC-MPC) (Docket No. 72-1025), which consists of a transportable storage canister, a vertical concrete storage cask, and a transfer cask. The transportable storage canister used for the Yankee Rowe used nuclear fuel is the Yankee-MPC, which holds 36 pressurized water reactor used nuclear fuel assemblies. The fuel assemblies from Yankee Rowe were loaded into NAC-MPC canisters from June 2002 through June 2003 (Leduc 2012). The fuel assemblies at Yankee Rowe are either Zircaloy-clad (457 assemblies) or stainless steel-clad (76 assemblies). The NAC-STC transportation cask (Docket No. 71-9235) is licensed to transport the YankeeMPC canisters, including canisters containing GTCC low-level radioactive waste. No NAC-STC transportation casks have been fabricated for use in the United States. Two NAC-STC transportation casks have been fabricated for use in China (Washington Nuclear Corporation 2003).

Figure 2-8 illustrates the number of used nuclear fuel assemblies at Yankee Rowe, based on their discharge year. The oldest fuel was discharged in 1972 and the last fuel was discharged in 1991. The median discharge year of the fuel is 1984 .

Figure 2-9 illustrates the number of used nuclear fuel assemblies at Yankee Rowe based on their burnup. The lowest burnup is 4.2 GWd/MTHM and the highest burnup is $36.0 \mathrm{GWd} / \mathrm{MTHM}$. The median burnup is $28.0 \mathrm{GWd}$ /MTHM. There are no high burnup used nuclear fuel assemblies (burnup greater than $45 \mathrm{GWd} / \mathrm{MTHM}$ ) stored at Yankee Rowe. 


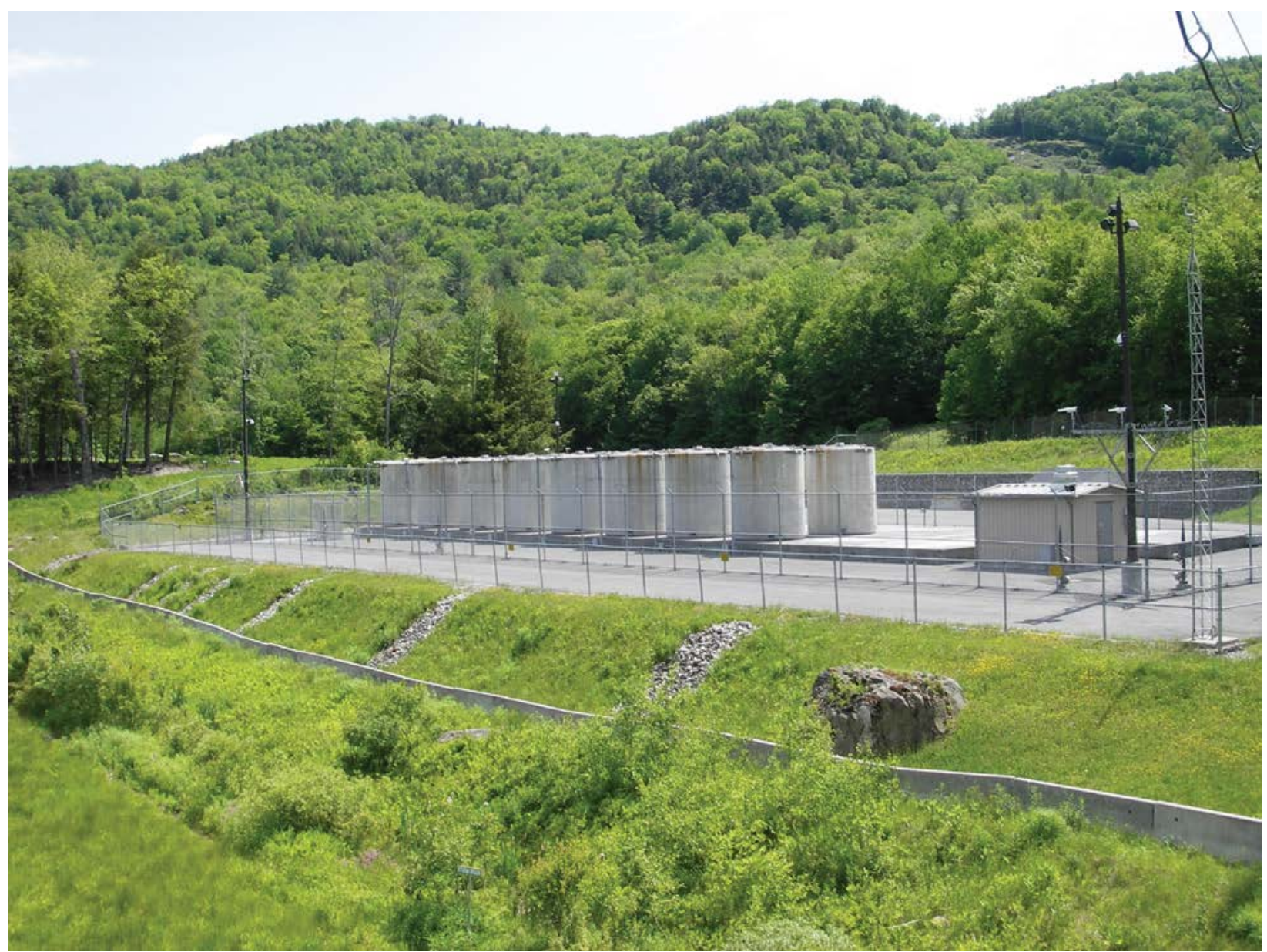

Photo courtesy of Yankee Rowe

Figure 2-7. Yankee Rowe Independent Spent Fuel Storage Installation 
Nuclear Fuels Storage and Transportation Planning Project A Preliminary Evaluation of Removing Used Nuclear Fuel From Nine Shutdown Sites April 30, 2013

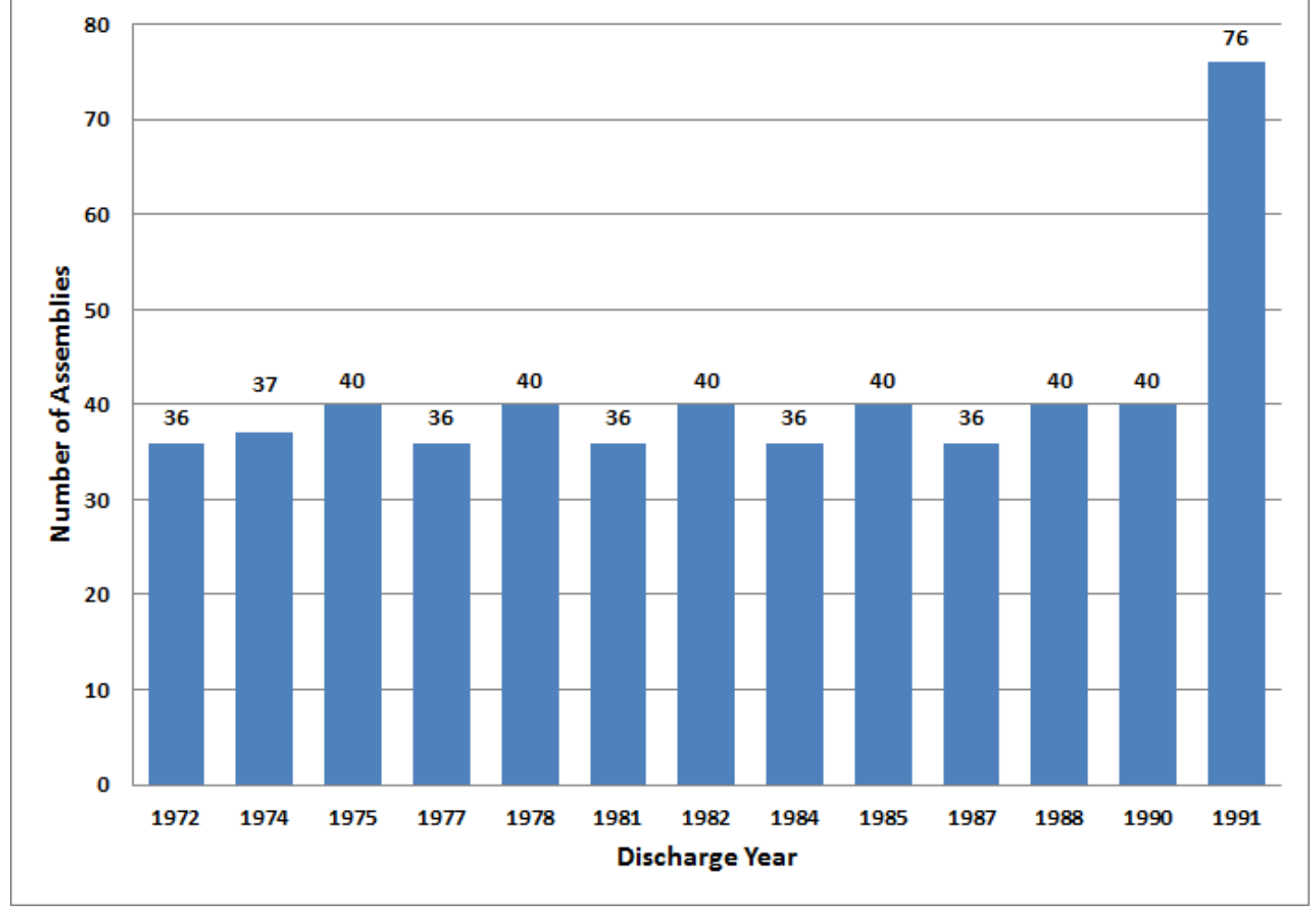

Figure 2-8. Yankee Rowe Number of Assemblies versus Discharge Year (EIA 2002)

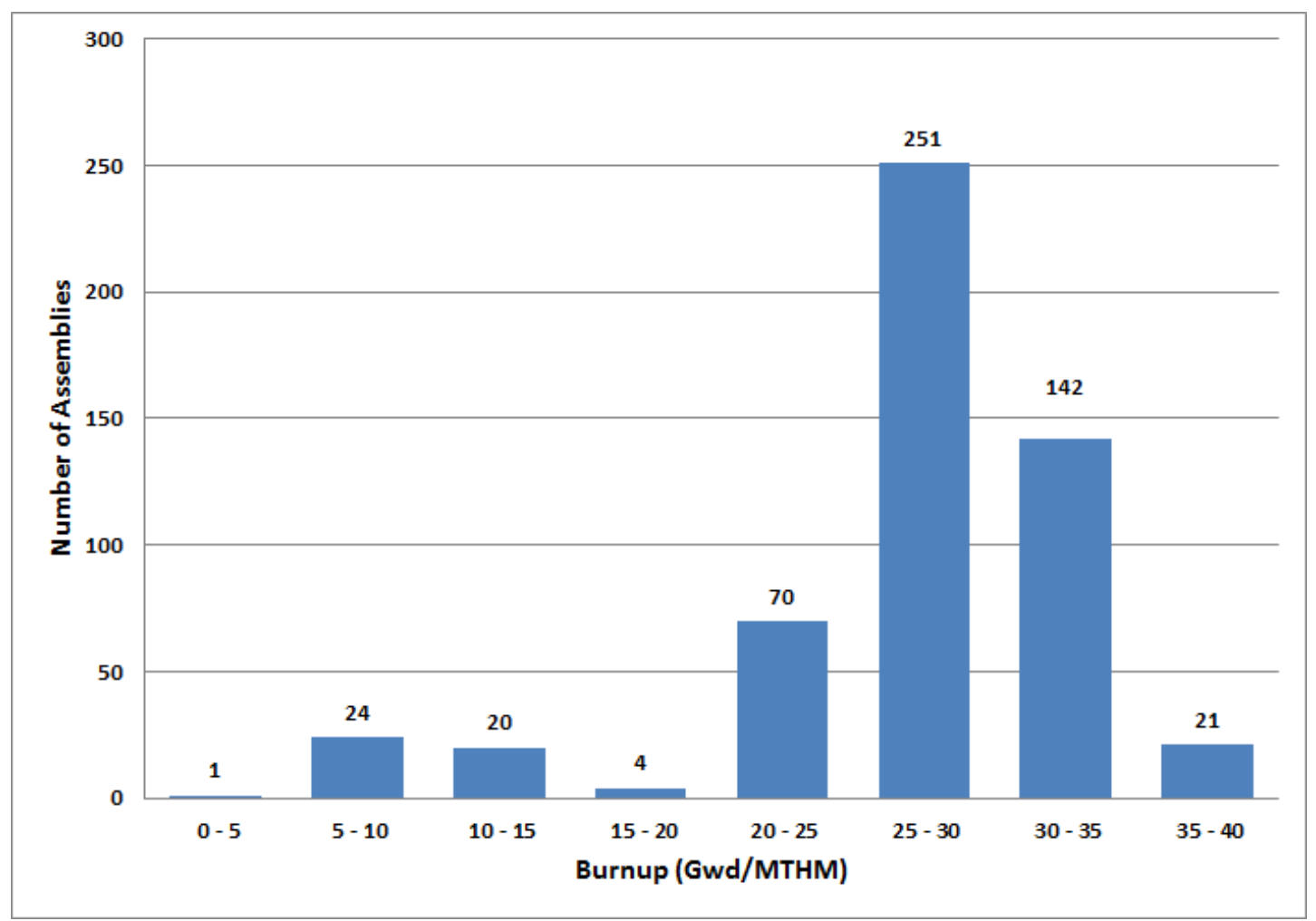

Figure 2-9. Yankee Rowe Number of Assemblies versus Burnup (EIA 2002) 


\subsection{Connecticut Yankee}

Forty canisters containing 1019 used nuclear fuel assemblies (412.3 MTHM) and 3 canisters of GTCC low-level radioactive waste are stored at Connecticut Yankee. Figure 2-10 shows the ISFSI at Connecticut Yankee. The storage system used at Connecticut Yankee is the NAC Multi-Purpose Canister system (NAC-MPC) (Docket No. 72-1025), which consists of a transportable storage canister, a vertical concrete storage cask, and a transfer cask. The transportable storage canister used for the Connecticut Yankee (CY) used nuclear fuel is the CY-MPC. This canister may be configured to hold 24 or 26 pressurized water reactor used nuclear fuel assemblies. The fuel assemblies from Connecticut Yankee were loaded into NAC-MPC canisters from May 2004 through March 2005 (Leduc 2012). The fuel assemblies at Connecticut Yankee are either Zircaloy-clad (161 assemblies) or stainless steel-clad (858 assemblies). The NAC-STC transportation cask (Docket No. 71-9235) is licensed to transport the NAC-MPC canisters, including canisters containing GTCC low-level radioactive waste. No NAC-STC transportation casks have been fabricated for use in the United States. Two NAC-STC transportation casks have been fabricated for use in China (Washington Nuclear Corporation 2003).

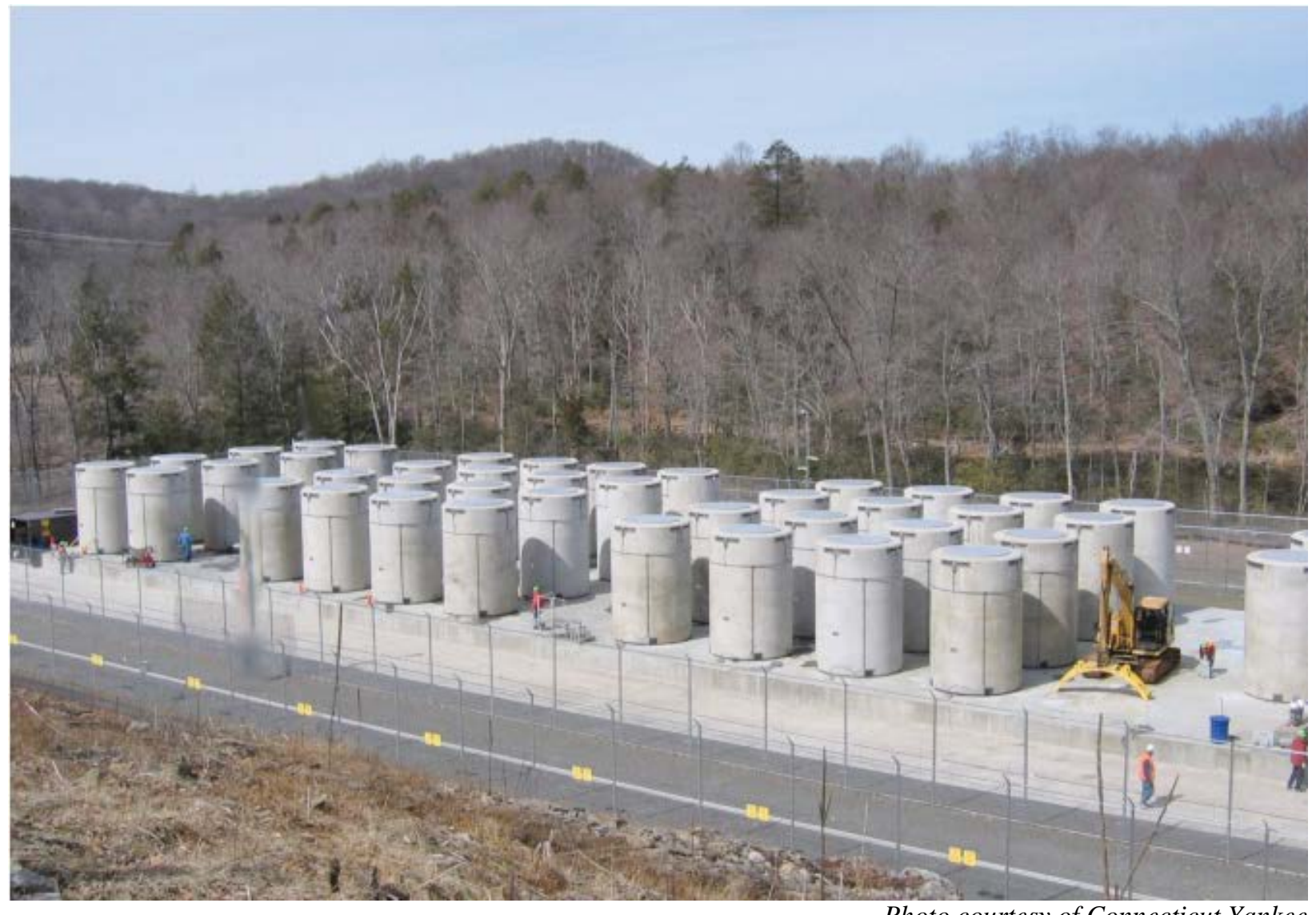

Figure 2-10. Connecticut Yankee Independent Spent Fuel Storage Installation 
In addition to the 43 canisters of used nuclear fuel and GTCC radioactive waste stored at the Connecticut Yankee ISFSI, there are two transfer casks stored at the Connecticut Yankee ISFSI.

Figure 2-11 illustrates the number of used nuclear fuel assemblies at Connecticut Yankee, based on their discharge year. The oldest fuel was discharged in 1971 and the last fuel was discharged in 1996. The median discharge year of the fuel is 1984 .

Figure 2-12 illustrates the number of used nuclear fuel assemblies at Connecticut Yankee, based on their burnup. The lowest burnup is $8.2 \mathrm{GWd} / \mathrm{MTHM}$ and the highest burnup is 43.0 GWd/MTHM. The median burnup is $33.1 \mathrm{GWd} / \mathrm{MTHM}$. There is no high burnup used nuclear fuel (burnup greater than 45 GWd/MTHM) stored at Connecticut Yankee.

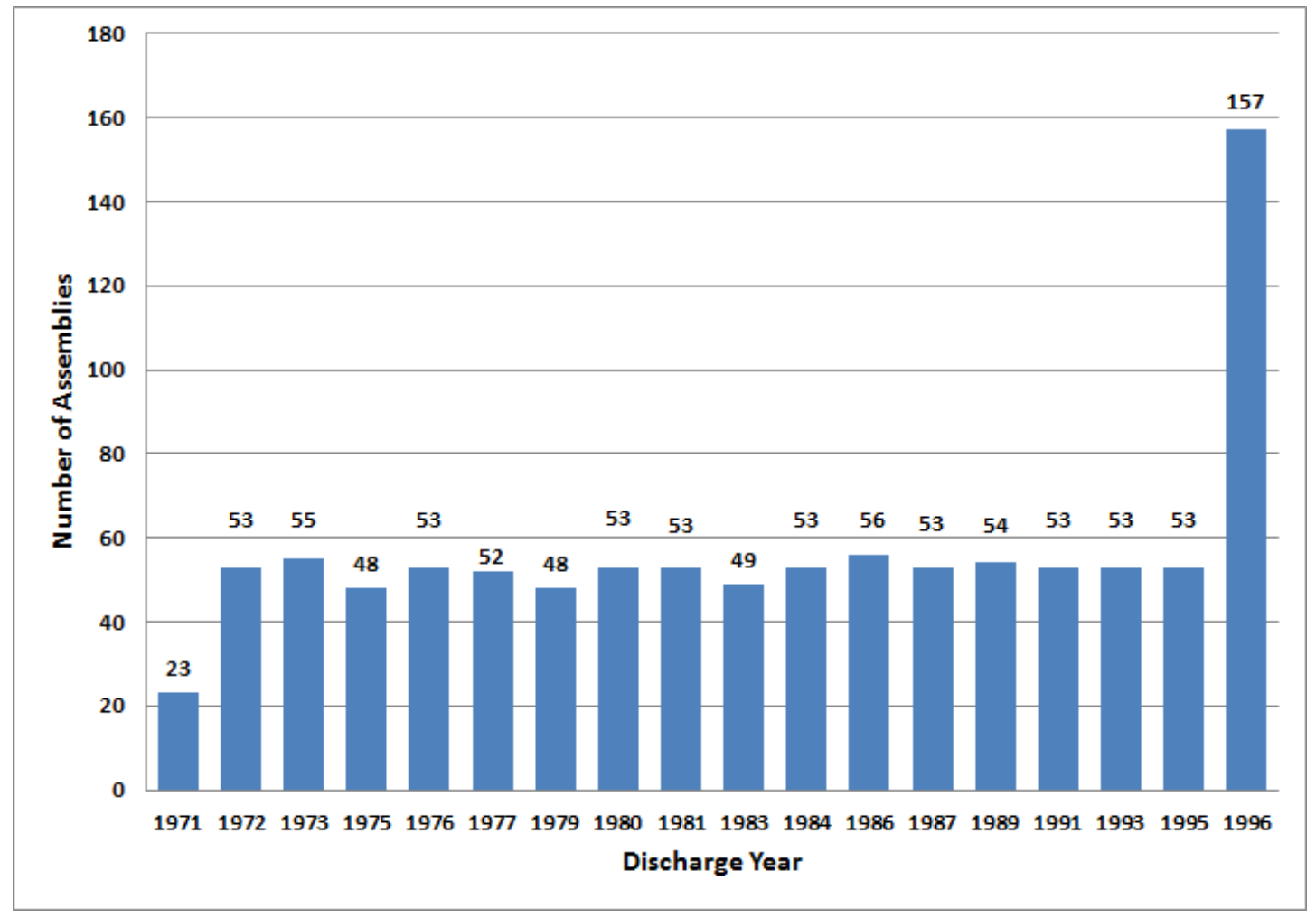

Figure 2-11. Connecticut Yankee Number of Assemblies versus Discharge Year (EIA 2002) 


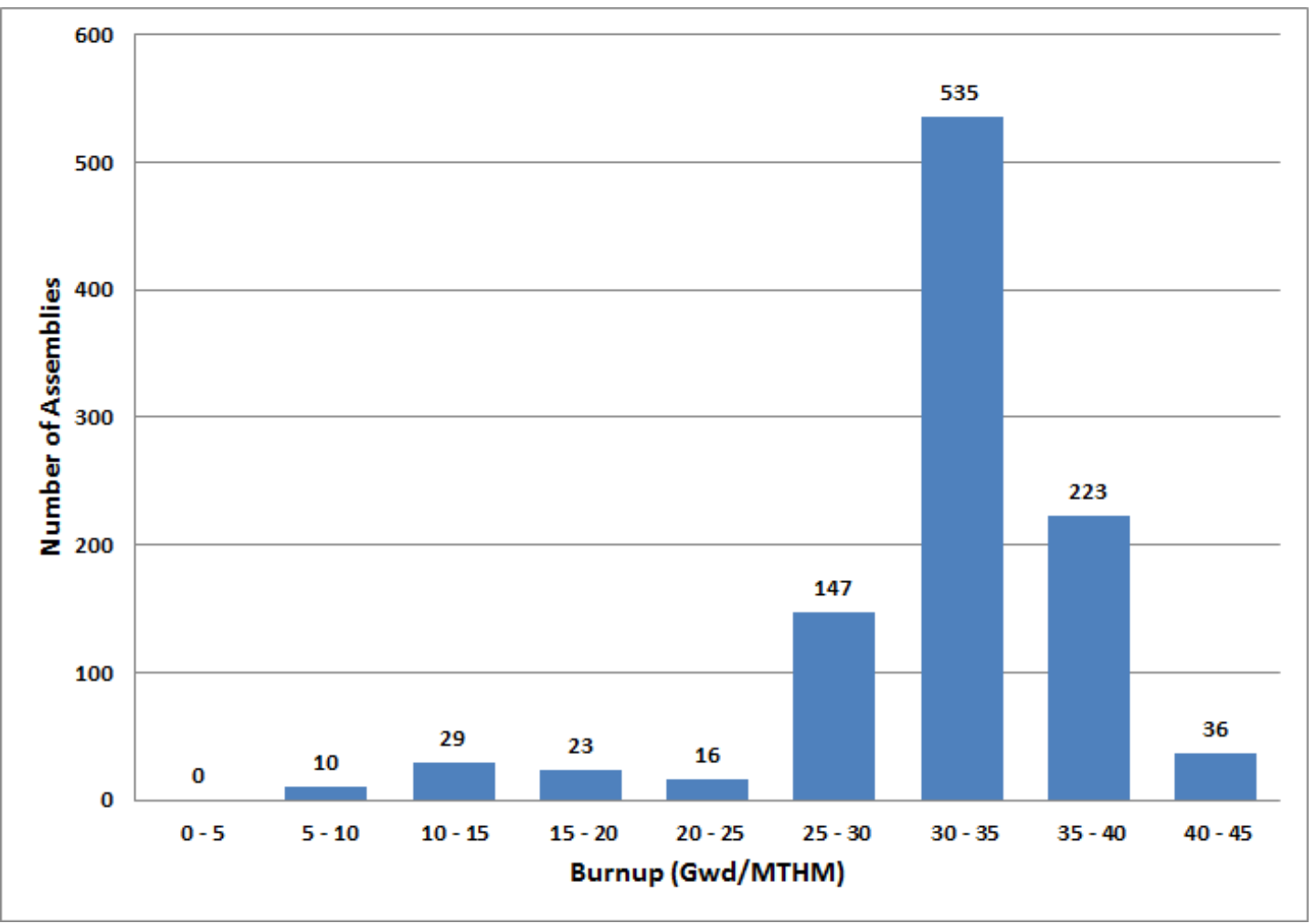

Figure 2-12. Connecticut Yankee Number of Assemblies versus Burnup (EIA 2002)

\subsection{Humboldt Bay}

Five canisters containing 390 used nuclear fuel assemblies (28.9 MTHM) are stored at Humboldt Bay. An additional canister of GTCC low-level radioactive waste is expected to be loaded and transferred to the ISFSI in spring 2013 (NRC 2012b). Figure 2-13 shows the ISFSI at Humboldt Bay. In contrast to other ISFSIs, the canisters at Humboldt Bay are stored in a below-grade vault.

The storage system used at Humboldt Bay is the Holtec HI-STAR HB system, which is a variation of the HI-STAR 100 system (Docket No. 72-1008). The system consists of a multipurpose canister inside an overpack designed for both storage and transportation. The MPC-HB canister used at Humboldt Bay can hold up to 80 boiling water reactor used nuclear fuel assemblies. The fuel assemblies from Humboldt Bay were loaded from August through December 2008 (Leduc 2012). The assemblies are Zircaloy-clad. The HI-STAR HB storage overpack used at Humboldt Bay is also transportable (Docket No. 71-9261); however, impact limiters are required and would need to be fabricated. In addition, the HI-STAR HB transportation cask is not licensed for the transport of GTCC low-level radioactive waste.

Figure 2-14 illustrates the number of used nuclear fuel assemblies at Humboldt Bay based on their discharge year. The oldest fuel was discharged in 1971 and the last fuel was discharged in 1976. The median discharge year of the fuel is 1975 . 


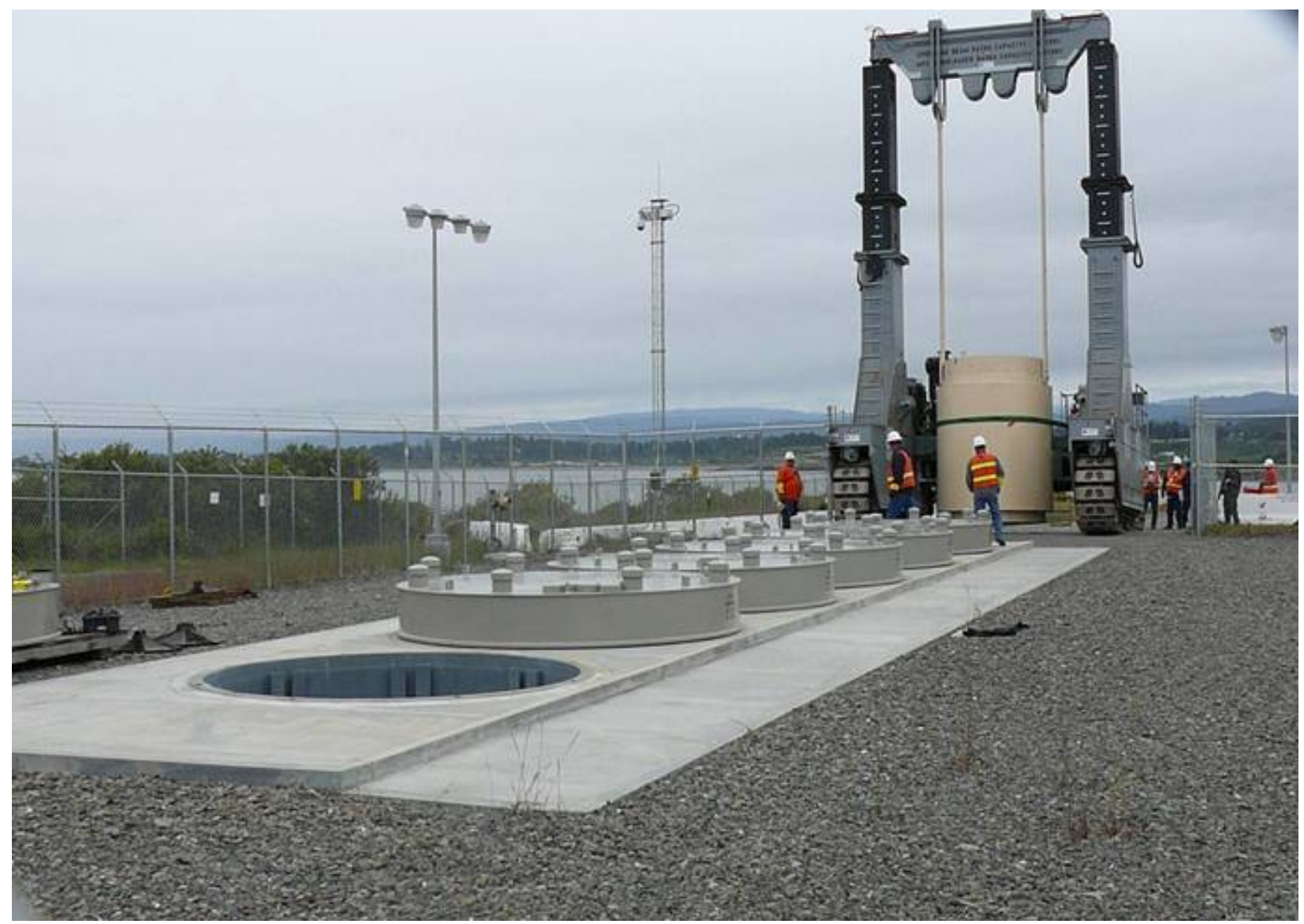

Photo courtesy of Humboldt Bay

Figure 2-13. Humboldt Bay Independent Spent Fuel Storage Installation 
Nuclear Fuels Storage and Transportation Planning Project A Preliminary Evaluation of Removing Used Nuclear Fuel From Nine Shutdown Sites

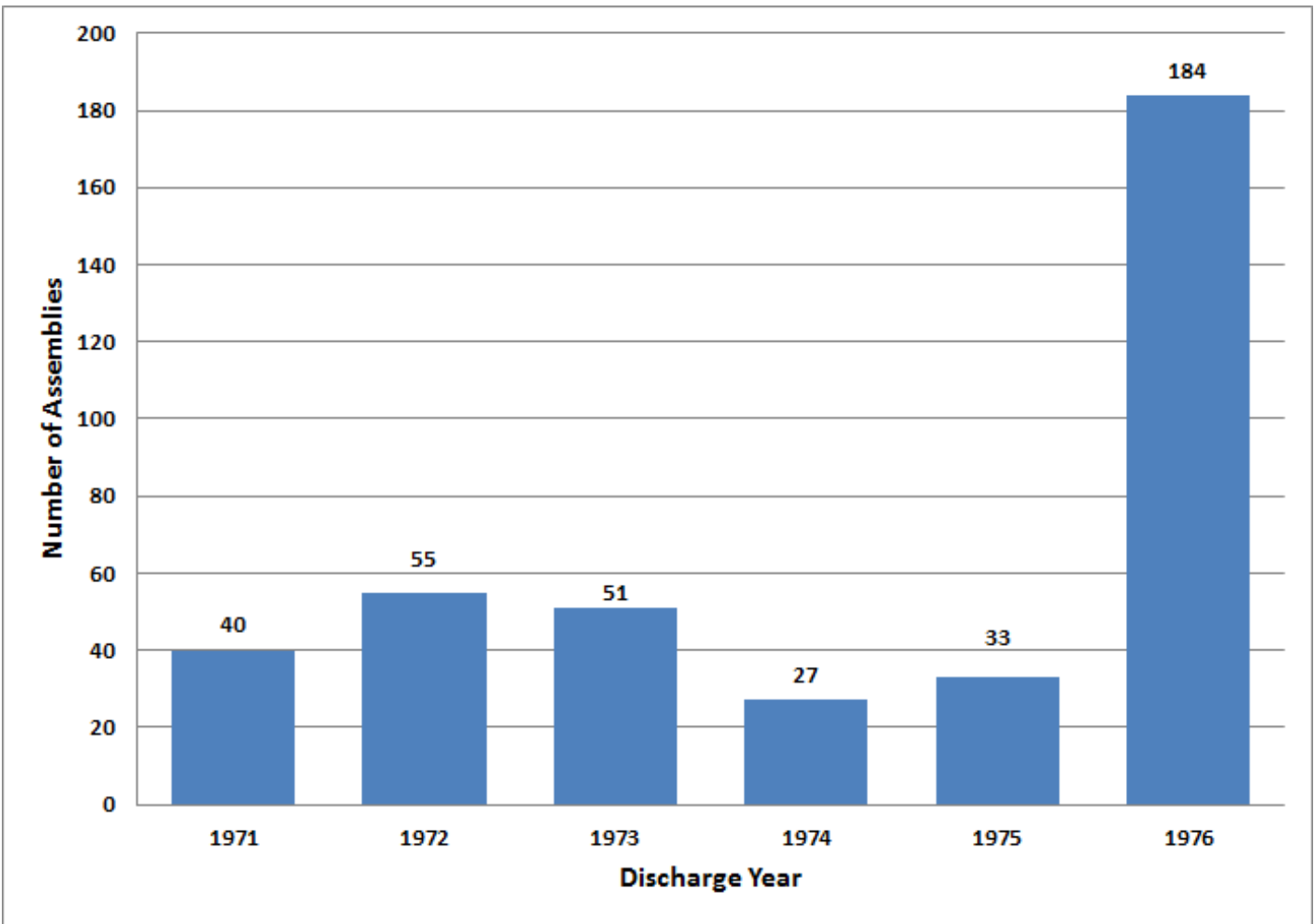

Figure 2-14. Humboldt Bay Number of Assemblies versus Discharge Year (EIA 2002)

Figure 2-15 illustrates the number of used nuclear fuel assemblies at Humboldt Bay based on their burnup. The lowest burnup is $1.3 \mathrm{GWd} / \mathrm{MTHM}$ and the highest burnup is 22.9 GWd/MTHM. The median burnup is $16.4 \mathrm{GWd} / \mathrm{MTHM}$. No high burnup used nuclear fuel (burnup greater than $45 \mathrm{GWd} / \mathrm{MTHM}$ ) is stored at Humboldt Bay. 


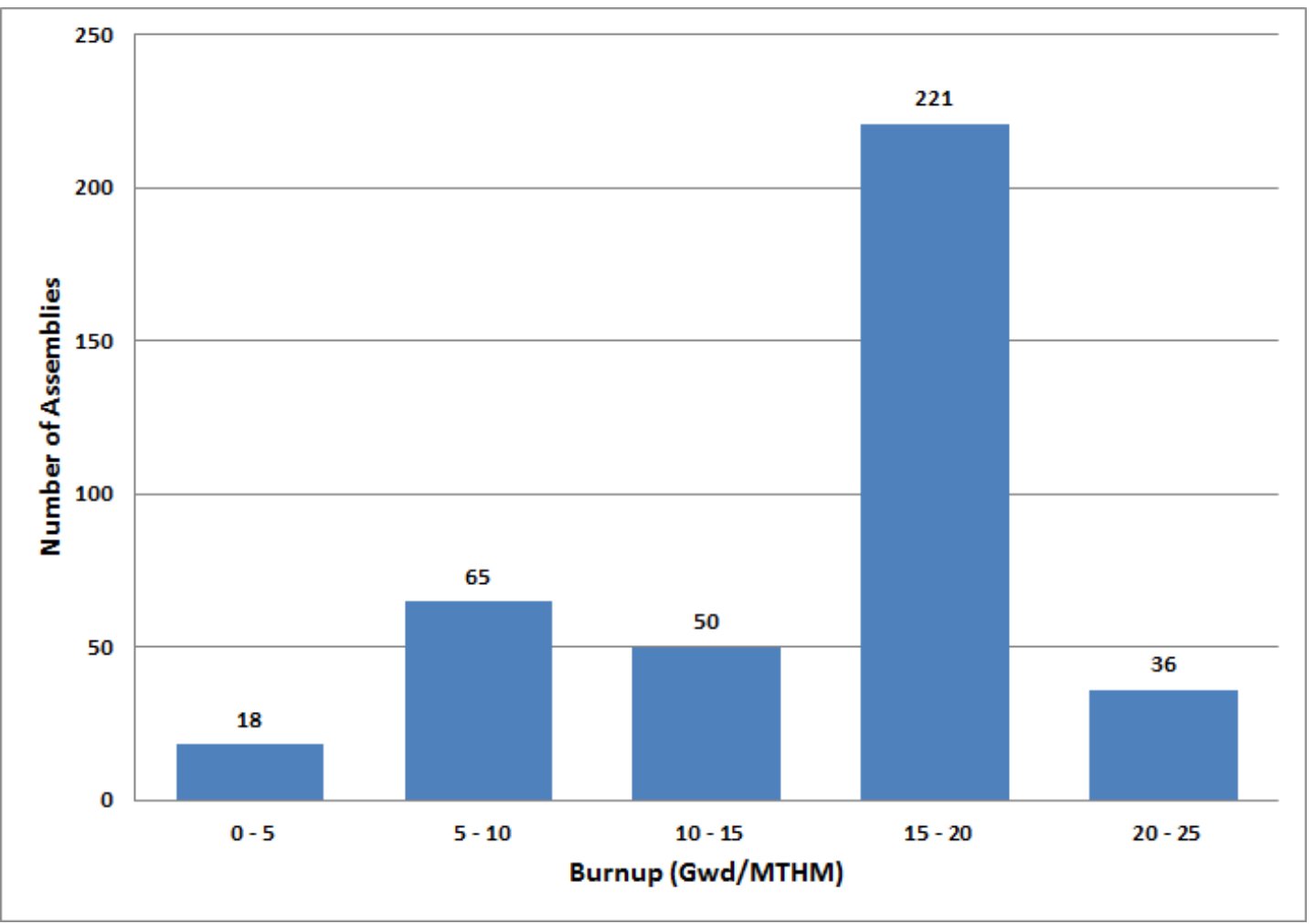

Figure 2-15. Humboldt Bay Number of Assemblies versus Burnup (EIA 2002)

\subsection{Big Rock Point}

Seven canisters containing 441 used nuclear fuel assemblies (57.9 MTHM) and 1 canister of GTCC low-level radioactive waste are stored at Big Rock Point. Figure 2-16 shows the ISFSI at Big Rock Point. The storage system used at Big Rock Point is the FuelSolutions Storage System which consists of the W74 canister, the W150 storage cask, and the W100 transfer cask (Docket No. 72-1026). The W74 canister holds 64 Big Rock Point boiling water reactor used nuclear fuel assemblies. The fuel assemblies from Big Rock Point were loaded into W74 canisters from December 2002 through March 2003 (Leduc 2012). The assemblies are Zircaloy-clad. The TS125 transportation cask (Docket No. 71-9276) is licensed to transport the W74 canister. No TS125 transportation casks have been fabricated either domestically or for use overseas. In addition, the TS125 transportation cask is not licensed for the transport of GTCC low-level radioactive waste.

In October 2012, the U.S. Nuclear Regulatory Commission issued a renewed certificate of compliance to EnergySolutions for the TS125 transportation cask. The renewed certificate of compliance expires on October 31, 2017 (NRC 2012c). The Safety Evaluation Report for the renewal of the certificate of compliance observes that no TS125 transportation casks have been fabricated and states that because the TS125 transportation cask has a -85 designation in its identification number [i.e., USA/9276/B(U)F-85], all fabrication of this package must have been completed by December 31, 2006, as required by 10 CFR 71.19(c). In order to fabricate TS125 


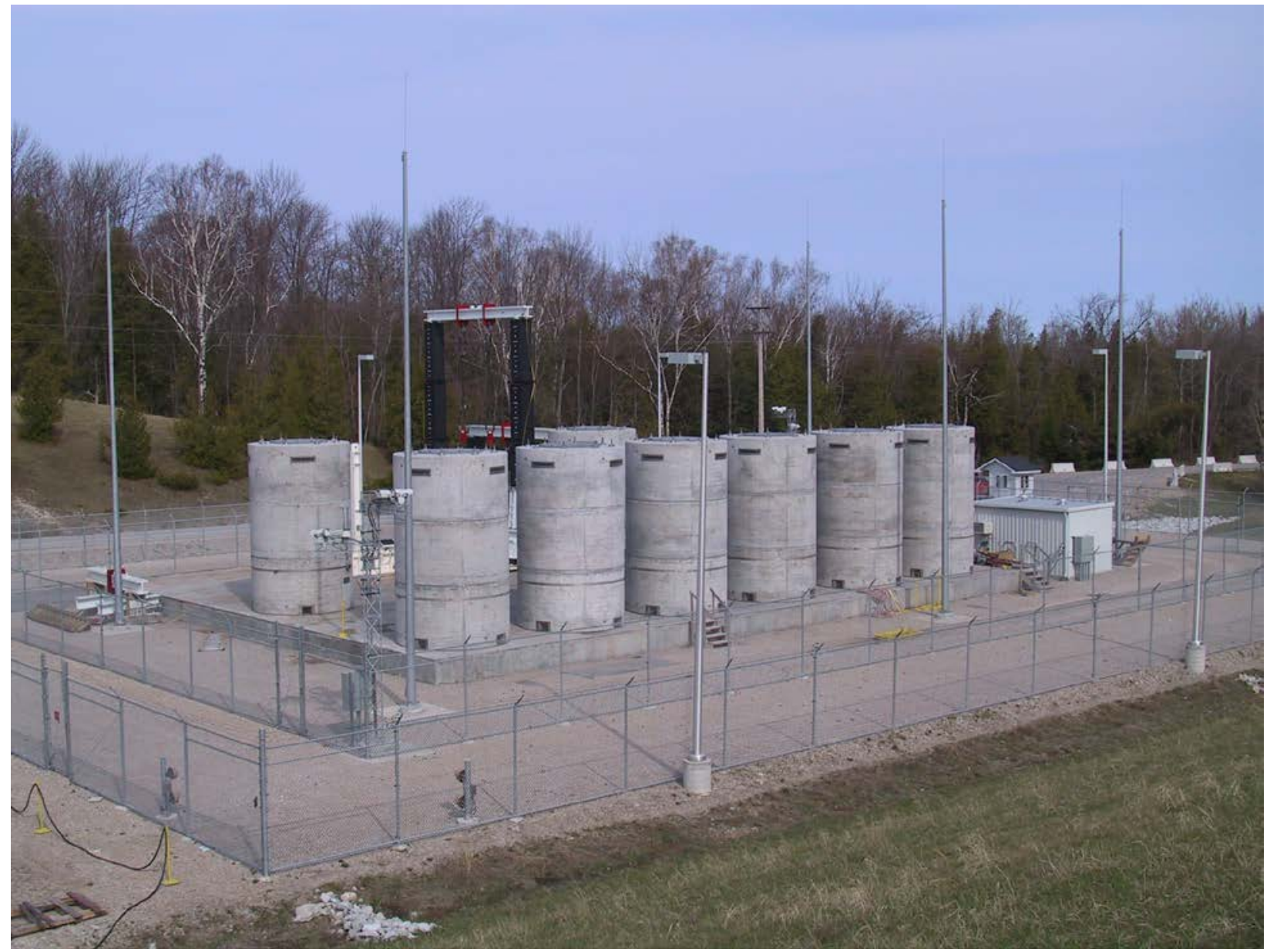

Photo courtesy of Big Rock Point

Figure 2-16. Big Rock Point Independent Spent Fuel Storage Installation

transportation casks, EnergySolutions would need to apply for a -96 designation by submitting a revised safety analysis report to demonstrate that the TS125 transportation cask meets the current NRC regulations contained in 10 CFR 71 . The revisions to the TS125 safety analysis report would include:

- Revised $A_{1}$ and $A_{2}$ values. EnergySolutions would need to update the containment analysis in Chapter 4 of the safety analysis report to incorporate revised $\mathrm{A}_{2}$ values in 10 CFR 71, Appendix A, Table A-1. An increase in the maximum allowable leakage rates for the TS125 transportation cask would be expected.

- Criticality Safety Index (CSI). EnergySolutions would need to revise Chapters 1, 5, and 6 of the TS125 transportation cask safety analysis report to incorporate the CSI nomenclature and the U.S. Nuclear Regulatory Commission would need to revise the certificate of compliance to delete references to the Transport Index for criticality control.

- Expansion of Quality Assurance (QA) Requirements. EnergySolutions would need to revise the safety analysis report for the TS125 transportation cask to demonstrate how its QA program satisfies the specific requirements of 10 CFR 71.101(a), (b), and (c). 
A -96 designation must also be obtained before the TS125 transportation cask is licensed for the transport of GTCC low-level radioactive waste. The effort to accomplish these changes and to obtain NRC review and approval is estimated to be not more than 1 year.

Figure 2-17 illustrates the number of used nuclear fuel assemblies at Big Rock Point based on their discharge year. The oldest fuel was discharged in 1974 and the last fuel was discharged in 1997. The median discharge year of the fuel is 1988.

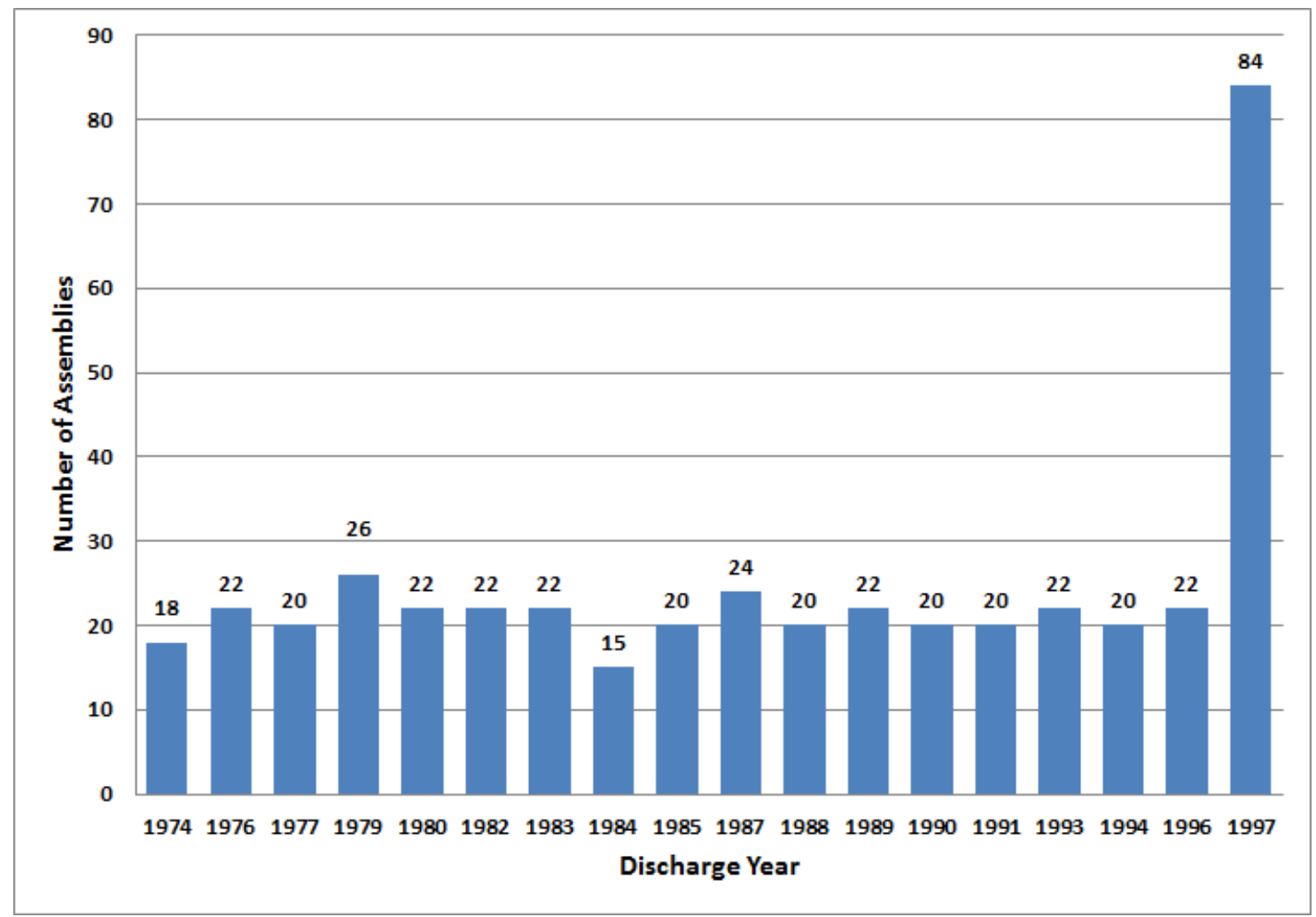

Figure 2-17. Big Rock Point Number of Assemblies versus Discharge Year (EIA 2002)

Figure 2-18 illustrates the number of used nuclear fuel assemblies at Big Rock Point based on their burnup. The lowest burnup is $3.5 \mathrm{GWd} / \mathrm{MTHM}$ and the highest burnup is 34.2 GWd/MTHM. The median burnup is 23.7 GWd/MTHM. No high burnup used nuclear fuel (burnup greater than $45 \mathrm{GWd} / \mathrm{MTHM}$ ) is stored at Big Rock Point. 


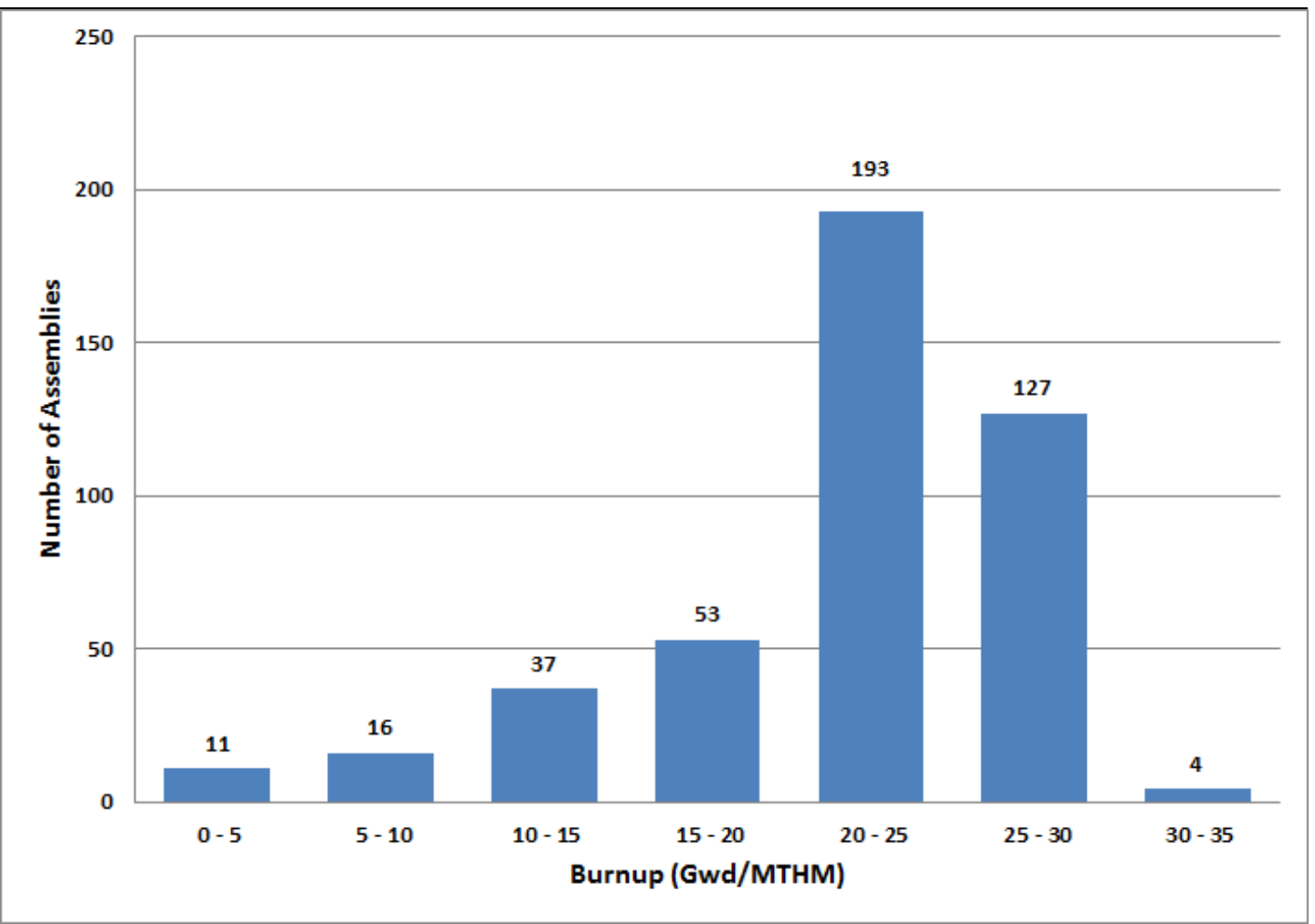

Figure 2-18. Big Rock Point Number of Assemblies versus Burnup (EIA 2002)

\subsection{Rancho Seco}

Twenty-one canisters containing 493 used nuclear fuel assemblies (228.4 MTHM) and 1 canister of GTCC low-level radioactive waste are stored at Rancho Seco. Figure 2-19 shows the ISFSI at Rancho Seco. The storage system used at Rancho Seco is a site-specific model of the Standardized NUHOMS-24P system (Docket No. 72-1004), which consists of transportable canisters, reinforced concrete horizontal storage modules, and a transfer cask. The canisters used at Rancho Seco are the fuel only dry shielded canister (FO-DSC), fuel with control component dry shielded canister (FC-DSC), and failed fuel dry shielded canister (FF-DSC). The FO-DSC and FC-DSC hold 24 pressurized water reactor used nuclear fuel assemblies and the FF-DSC holds 13 pressurized water reactor used nuclear fuel assemblies. The fuel assemblies from Rancho Seco were loaded from April 2001 through August 2002 (Leduc 2012). The assemblies are Zircaloy-clad. The transfer cask used at Rancho Seco is the MP187 transportation cask, which is also licensed for offsite transportation of the FO-DSC, FC-DSC, and FF-DSC (Docket No. 71-9255). The MP187 used to load the Rancho Seco ISFSI is stored at the Rancho Seco site. Impact limiters are required for the MP187 and would need to be fabricated. In addition, the MP187 transportation cask is not licensed for the transport of GTCC low-level radioactive waste. 


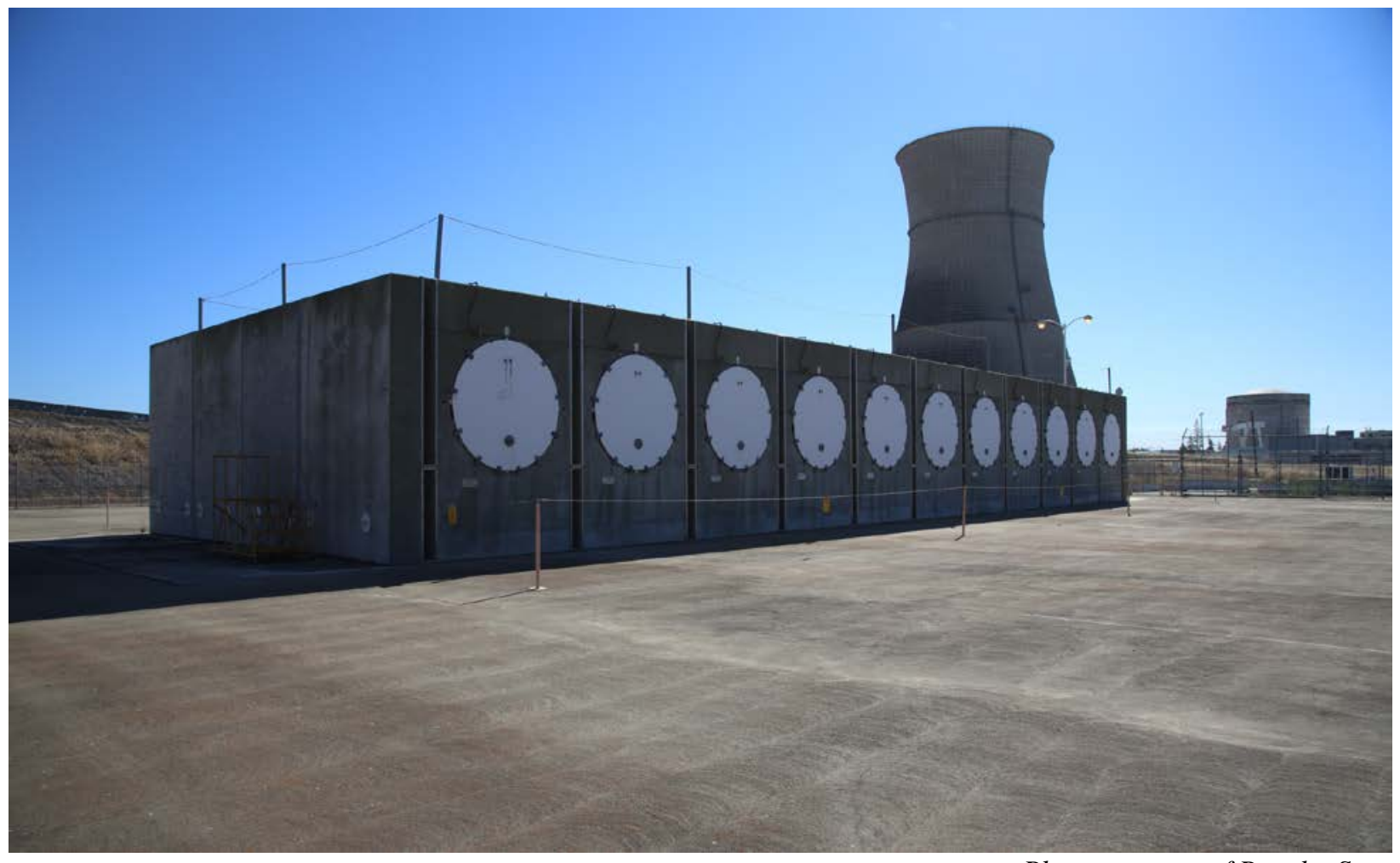

Figure 2-19. Rancho Seco Independent Spent Fuel Storage Installation

The certificate of compliance for the MP187 transportation cask has a -85 designation in its identification number [i.e., USA/9255/B(U)F-85]. U.S. Nuclear Regulatory Commission regulation 10 CFR 71.19(c) requires that all fabrication of transportation casks with a -85 designation must have been completed by December 31, 2006. To date, one MP187 transportation cask has been fabricated, and before additional MP187 transportation casks are fabricated, Transnuclear would need to apply for a -96 designation by submitting a revised safety analysis report to demonstrate that the MP187 transportation cask meets the current NRC regulations contained in 10 CFR 71 . The revisions to the MP187 safety analysis report would include:

- Revised $\mathrm{A}_{1}$ and $\mathrm{A}_{2}$ values. Transnuclear would need to update the containment analysis in Chapter 4 of the safety analysis report to incorporate revised $A_{2}$ values in 10 CFR 71, Appendix A, Table A-1. An increase in the maximum allowable leakage rates for the MP187 transportation cask would be expected.

- Criticality Safety Index (CSI). Transnuclear would need to revise Chapters 1, 5, and 6 of the MP187 transportation cask safety analysis report to incorporate the CSI nomenclature and the NRC would need to revise the certificate of compliance to delete references to the Transport Index for criticality control.

- Expansion of QA Requirements. Transnuclear would need to revise the safety analysis report for the MP187 transportation cask to demonstrate how its QA program satisfies the specific requirements of 10 CFR 71.101(a), (b), and (c). 
Representatives of Transnuclear have also stated that the -96 designation must be obtained before impact limiters are fabricated for the existing MP187 transportation cask. ${ }^{2}$ A -96 designation must also be obtained before the MP187 transportation cask is licensed for the transport of GTCC low-level radioactive waste. The effort to accomplish these changes and to obtain NRC review and approval is estimated to be not more than 1 year.

There are six damaged fuel assemblies stored in five FC-DSCs at Rancho Seco. When this fuel was originally packaged in canisters, the fuel was visually inspected and classified as damaged if cladding failures with breaches greater than 25 percent of the circumference of the fuel pin and at least the length of a fuel pellet ( 0.34 inches across the cladding and 0.7 inches along the cladding) were present (Redeker 2006). Fuel assemblies not classified as damaged using this definition were classified as intact. The current definition of intact fuel is more restrictive, where fuel assemblies are classified as intact if they contain no cladding breaches (NRC 2007). Assemblies are classified as undamaged if they have no defects greater than hairline cracks or pinhole leaks (NRC 2007). This change in the definition of damaged and intact fuel resulted in the six fuel assemblies formerly classified as intact being classified as damaged, using the new definition. The Rancho Seco storage license was amended to recognize this situation; however, damaged fuel assemblies are normally required to be shipped in FF-DSCs, not in FC-DSCs, so the transportability of the six damaged fuel assemblies in the five FC-DSCs would need to be determined. In addition, the Safety Evaluation Report for the Rancho Seco ISFSI (NRC 2009) noted that visual examination alone is no longer a sufficient method for classifying assemblies as damaged or intact. NRC (2009) also stated that prior to transporting the used nuclear fuel stored at Rancho Seco, fuel classification may need to be revisited, and the damaged fuel assemblies (and potentially the intact fuel assemblies) may need to be placed into damaged fuel cans to be transportable.

Figure 2-20 illustrates the number of used nuclear fuel assemblies at Rancho Seco based on their discharge year. The oldest fuel was discharged in 1977 and the last fuel was discharged in 1989. The median discharge year of the fuel is 1983 .

Figure 2-21 illustrates the number of used nuclear fuel assemblies at Rancho Seco based on their burnup. The lowest burnup is $10.0 \mathrm{GWd} / \mathrm{MTHM}$ and the highest burnup is $38.2 \mathrm{GWd} / \mathrm{MTHM}$. The median burnup is 28.0 GWd/MTHM. No high burnup used nuclear fuel (burnup greater than 45 GWd/MTHM) is stored at Rancho Seco.

\footnotetext{
${ }^{2}$ Best RE. 2013. Email message from P Murray (AREVA) to RE Best (Consultant), “MP187 Question,” April 2, 2013.
} 
Nuclear Fuels Storage and Transportation Planning Project A Preliminary Evaluation of Removing Used Nuclear Fuel From Nine Shutdown Sites April 30, 2013

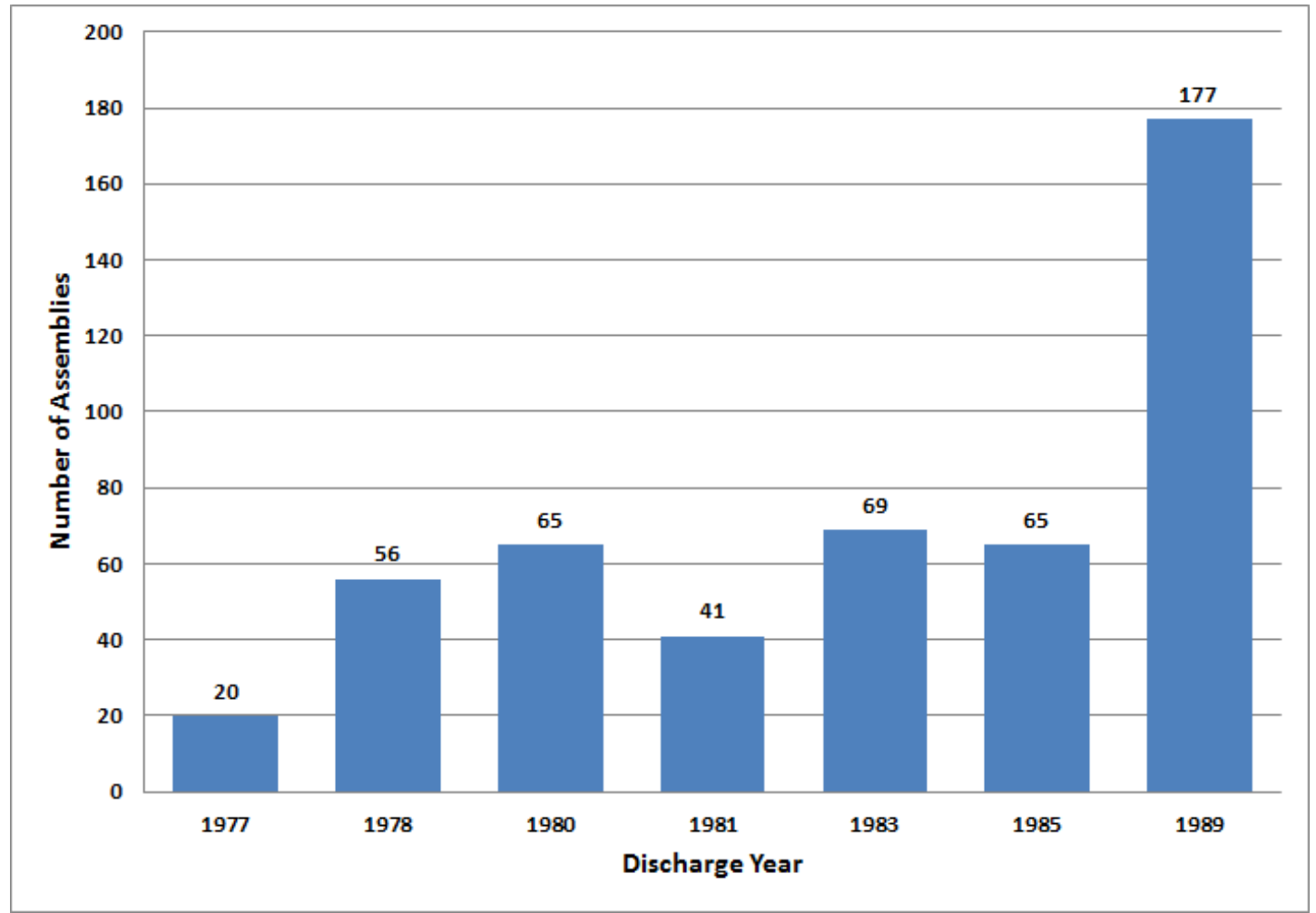

Figure 2-20. Rancho Seco Number of Assemblies versus Discharge Year (EIA 2002)

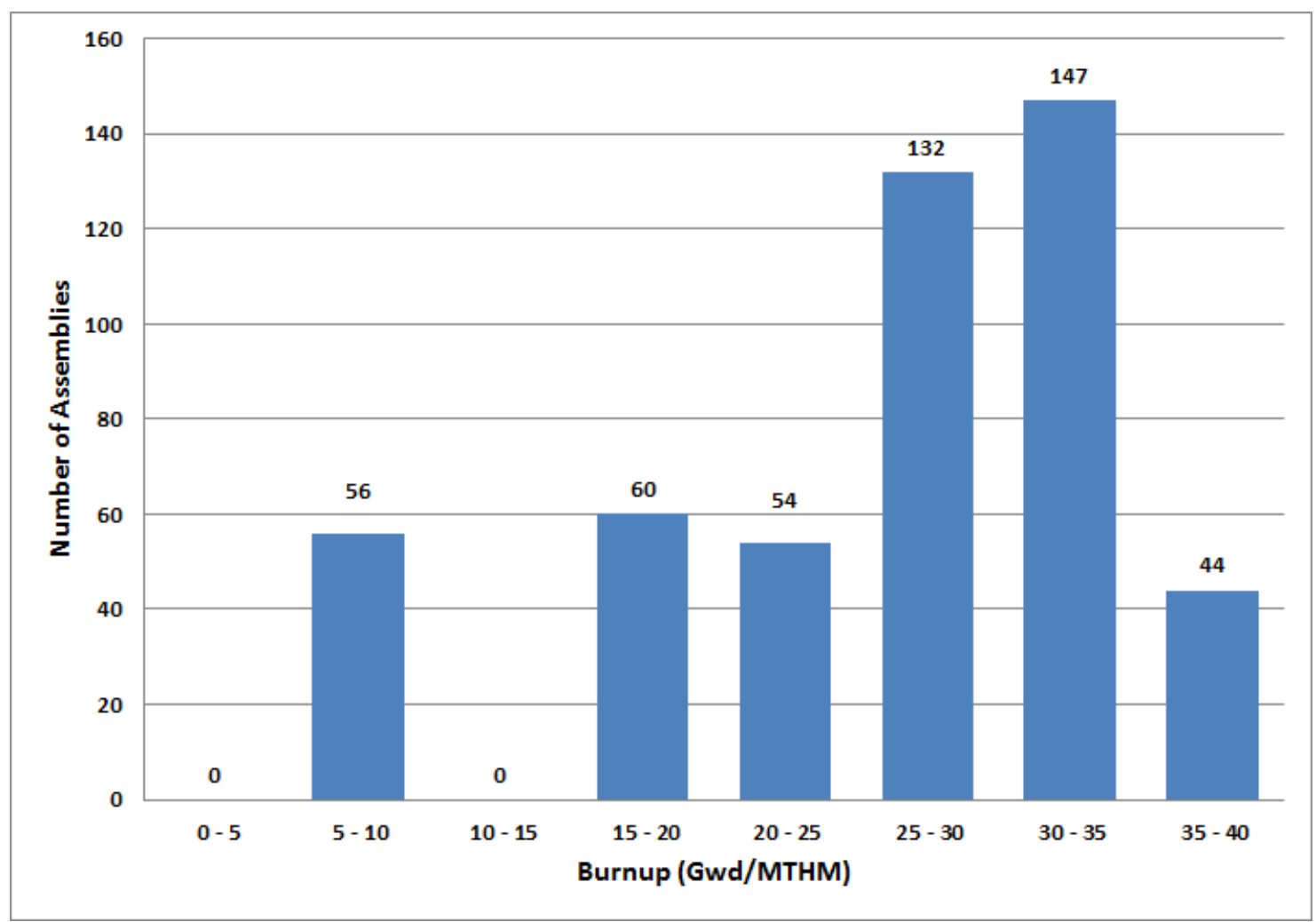

Figure 2-21. Rancho Seco Number of Assemblies versus Burnup (EIA 2002) 


\section{$2.7 \quad$ Trojan}

Thirty-four canisters containing 780 used nuclear fuel assemblies (358.9 MTHM) and no canisters of GTCC low-level radioactive waste are stored at Trojan. Figure 2-22 shows the ISFSI at Trojan. The storage system used at Trojan is a hybrid of two storage systems (EPRI 2010), and consists of TranStor concrete storage overpacks and Holtec MPC-24E and MPC-24EF canisters. The MPC-24E and the MPC-24EF canisters hold 24 pressurized water reactor used nuclear fuel assemblies. The fuel assemblies from Trojan were loaded into Holtec canisters from December 2002 through September 2003 (Leduc 2012). The fuel assemblies are Zircaloy-clad. The HI-STAR 100 transportation cask (Docket No. 71-9261) is licensed to transport the MPC-24E and the MPC-24EF canisters. Although HI-STAR 100 casks have been constructed for use in the United States, the casks are already being used as storage casks at the Dresden and Hatch sites (Ux Consulting 2012). For the HI-STAR 100 casks to be used to ship used nuclear fuel from the Trojan site, they would need to be unloaded, their contents placed in other storage overpacks at the Dresden and Hatch sites, and the casks transported to the Trojan site. It would also be necessary to procure impact limiters for the HI-STAR 100 casks.

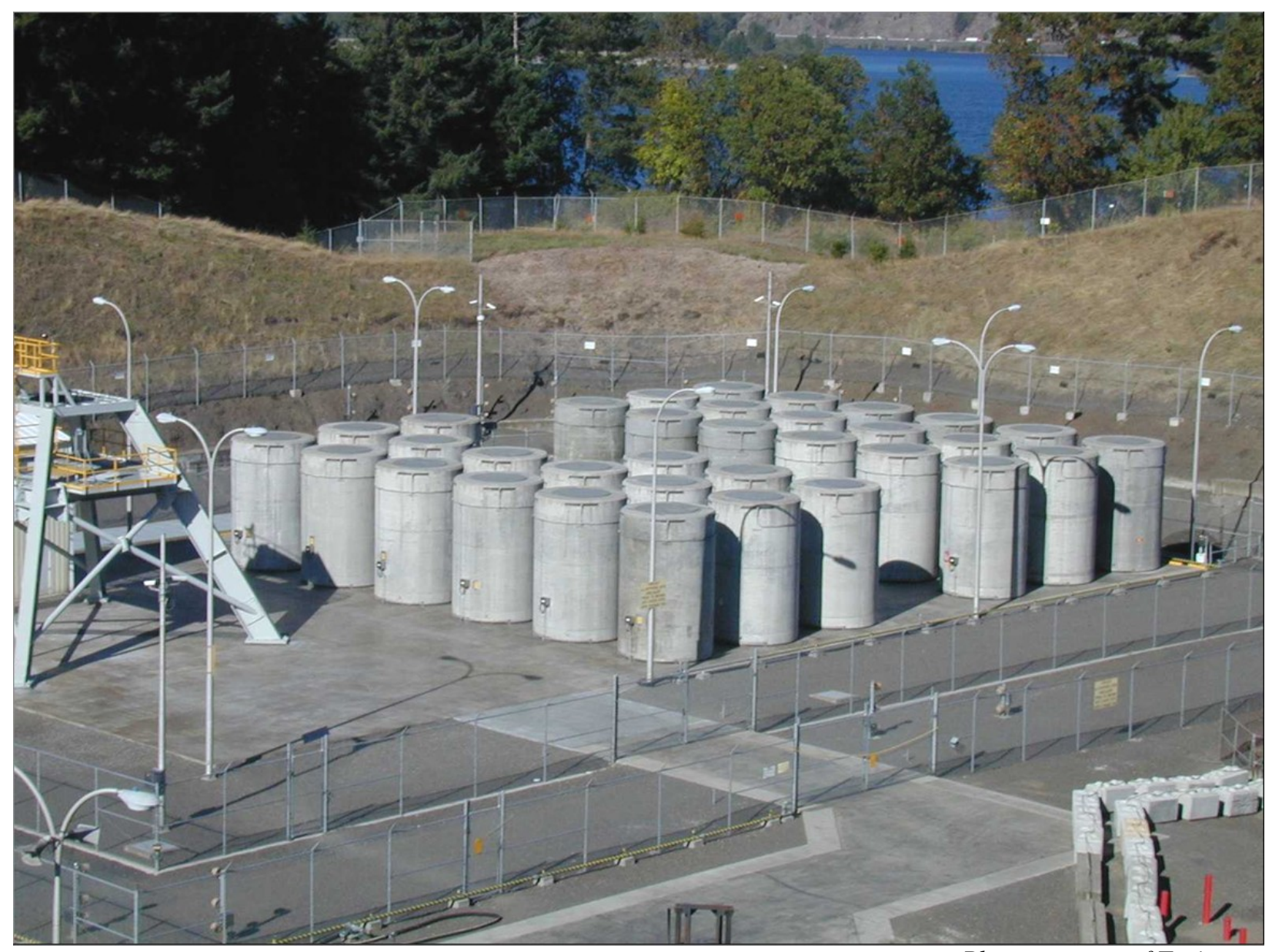

Figure 2-22. Trojan Independent Spent Fuel Storage Installation 
Figure 2-23 illustrates the number of used nuclear fuel assemblies at Trojan based on their discharge year. The oldest fuel was discharged in 1978 and the last fuel was discharged in 1992. The median discharge year of the fuel is 1988 .

Figure 2-24 illustrates the number of used nuclear fuel assemblies at Trojan based on their burnup. The lowest burnup is $5.0 \mathrm{GWd} / \mathrm{MTHM}$ and the highest burnup is $42.1 \mathrm{GWd} / \mathrm{MTHM}$. The median burnup is $33.4 \mathrm{GWd} / \mathrm{MTHM}$. No high burnup used nuclear fuel (burnup greater than $45 \mathrm{GWd} / \mathrm{MTHM}$ ) is stored at Trojan.

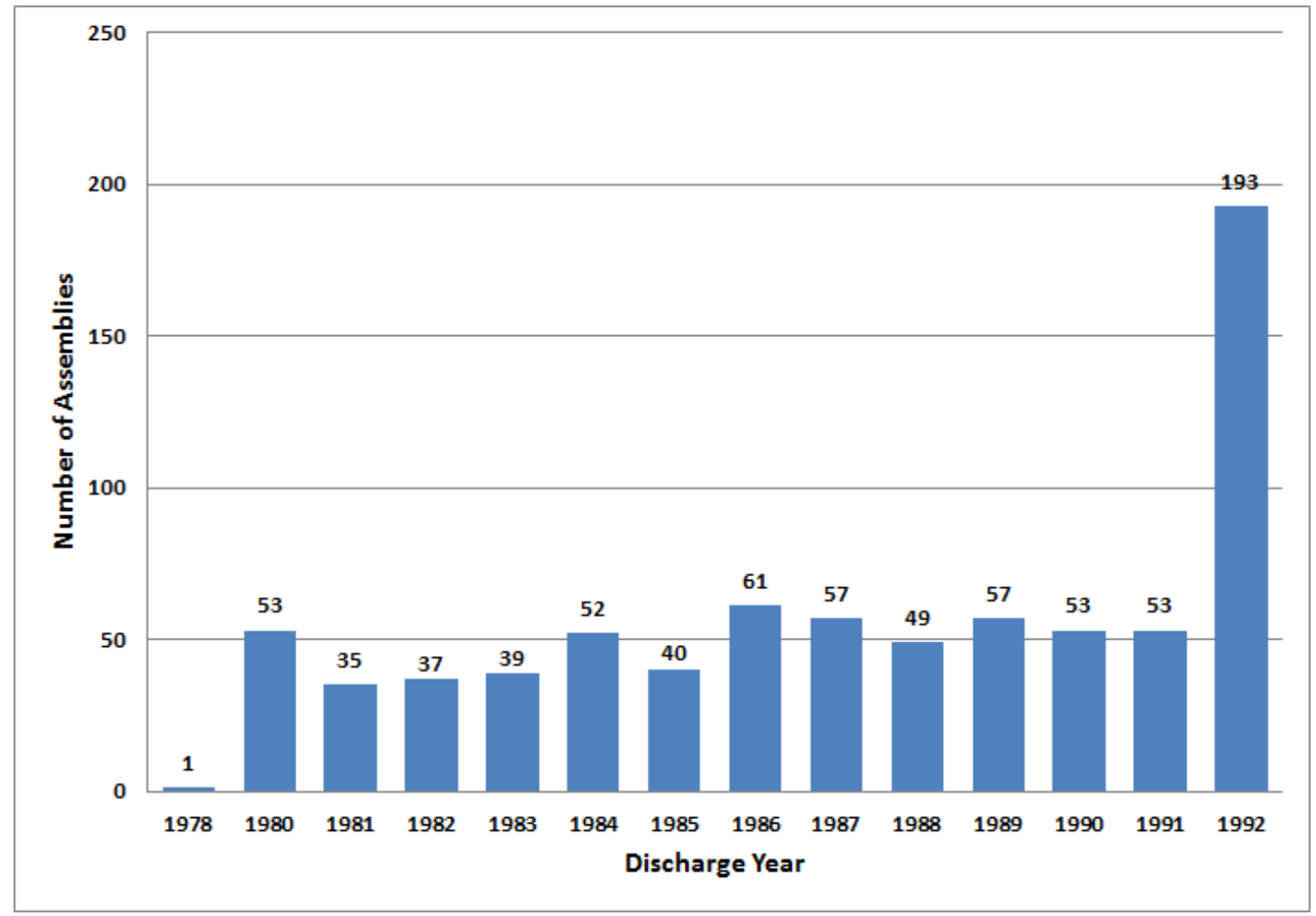

Figure 2-23. Trojan Number of Assemblies versus Discharge Year (EIA 2002) 


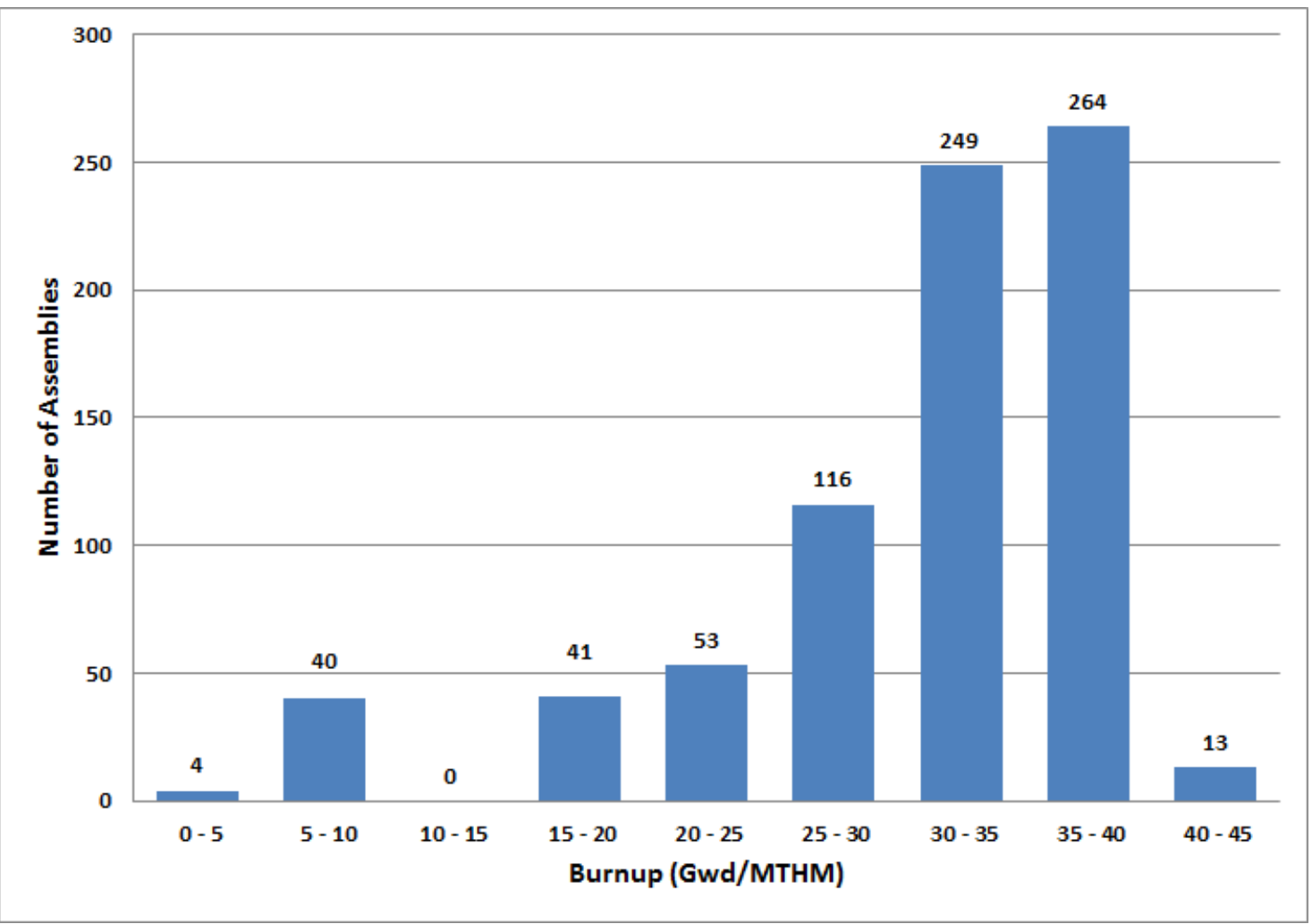

Figure 2-24. Trojan Number of Assemblies versus Burnup (EIA 2002)

\subsection{La Crosse}

Five canisters containing 333 used nuclear fuel assemblies (37.0 MTHM) are stored at La Crosse. La Crosse is undergoing decommissioning, so additional canisters containing GTCC low-level radioactive waste could be generated. Figure 2-25 shows the ISFSI at La Crosse. The storage system used at La Crosse is the NAC Multi-Purpose Canister system (NAC-MPC) (Docket No. 72-1025), which consists of a transportable storage canister, a vertical concrete storage cask, and a transfer cask. The transportable storage canister used for the La Crosse used nuclear fuel is the MPC-LACBWR. This canister holds $68 \mathrm{La}$ Crosse boiling water reactor used nuclear fuel assemblies. The fuel assemblies from La Crosse were loaded into MPC-LACBWR canisters from July through September 2012. The assemblies are stainless steel-clad. The NAC-STC transportation cask (Docket No. 71-9235) is licensed to transport the MPC-LACBWR canister. No NAC-STC transportation casks have been fabricated for use in the United States. Two NAC-STC transportation casks have been fabricated for use in China (Washington Nuclear Corporation 2003).

Figure 2-26 illustrates the number of used nuclear fuel assemblies at La Crosse, based on their discharge year. The oldest fuel was discharged in 1972 and the last fuel was discharged in 1987. The median discharge year of the fuel is 1982 . 
Figure 2-27 illustrates the number of used nuclear fuel assemblies at La Crosse based on their burnup. The lowest burnup is $4.7 \mathrm{GWd} / \mathrm{MTHM}$ and the highest burnup is $21.5 \mathrm{GWd} / \mathrm{MTHM}$. The median burnup is $15.7 \mathrm{GWd} / \mathrm{MTHM}$. No high burnup used nuclear fuel (burnup greater than $45 \mathrm{GWd} / \mathrm{MTHM}$ ) is stored at La Crosse.

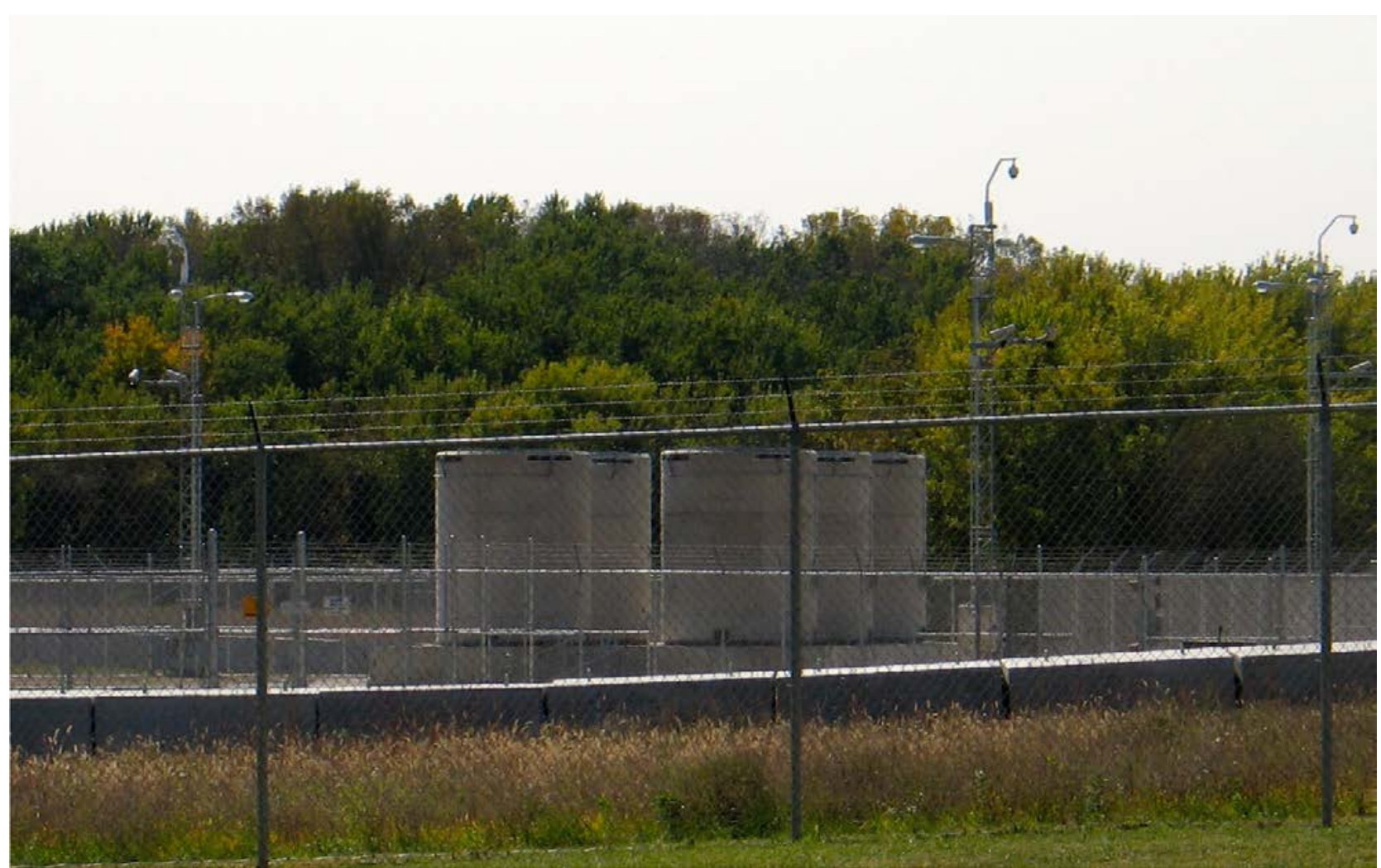

Figure 2-25. La Crosse Independent Spent Fuel Storage Installation 
Nuclear Fuels Storage and Transportation Planning Project A Preliminary Evaluation of Removing Used Nuclear Fuel From Nine Shutdown Sites

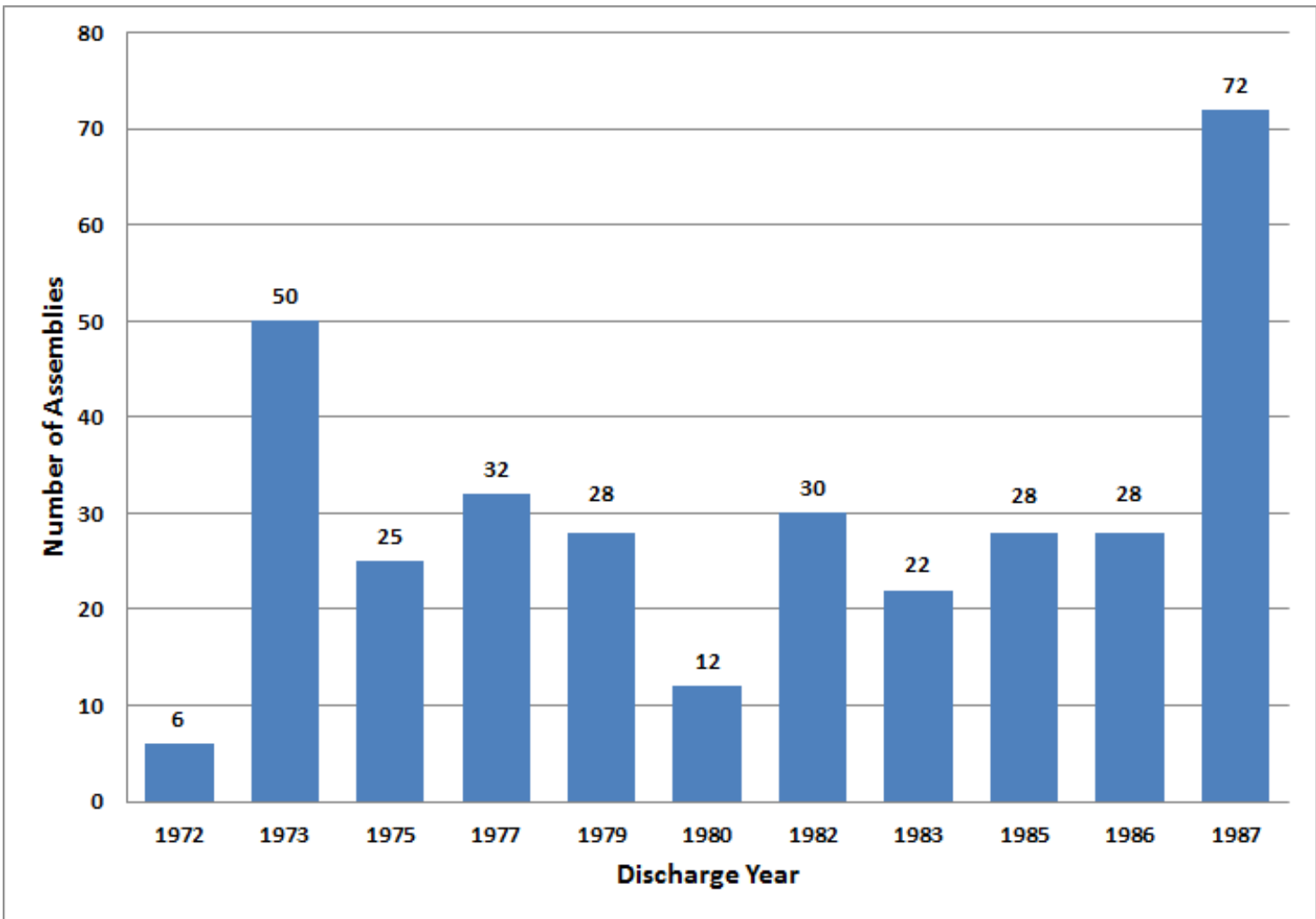

Figure 2-26. La Crosse Number of Assemblies versus Discharge Year (EIA 2002) 


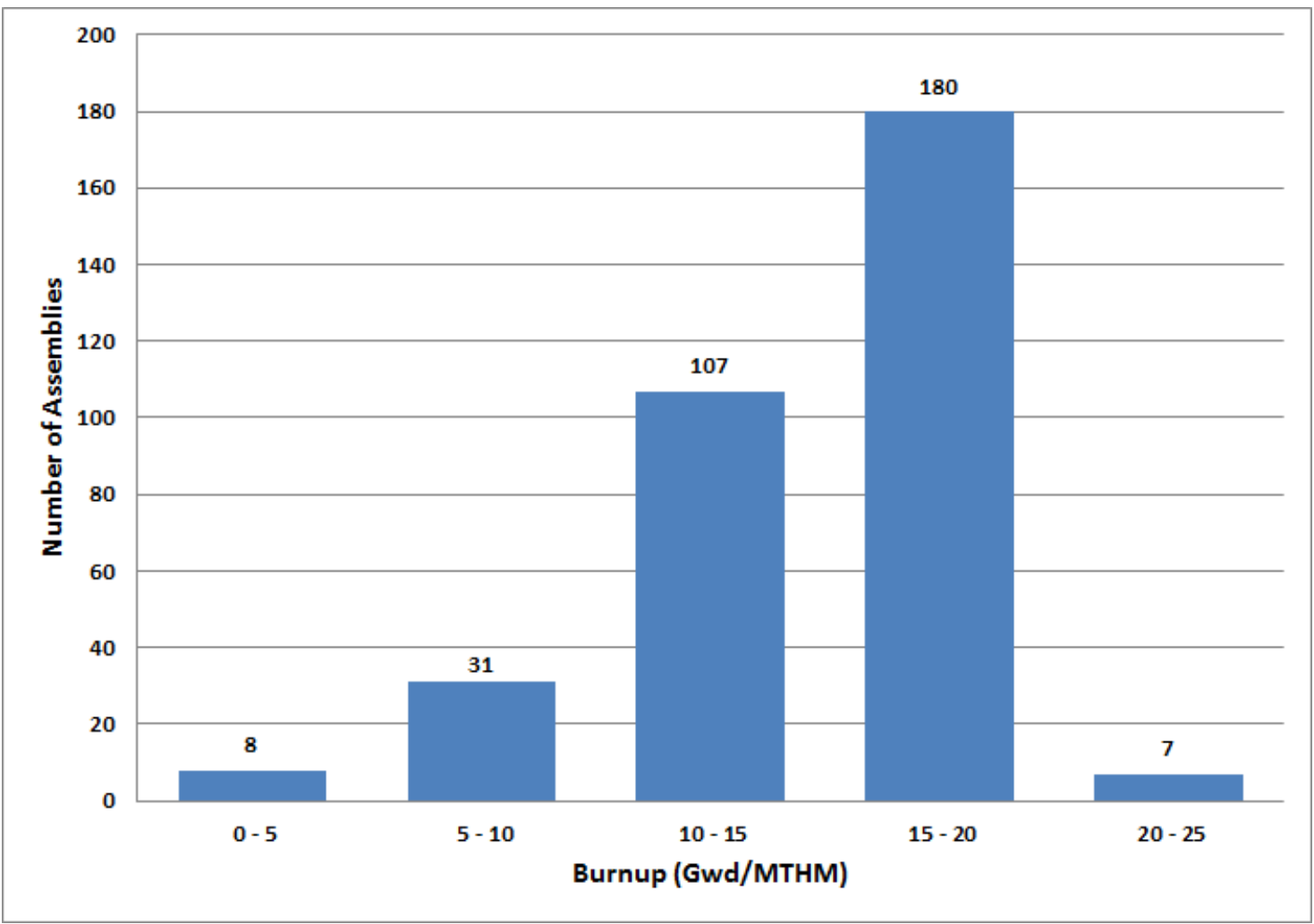

Figure 2-27. La Crosse Number of Assemblies versus Burnup (EIA 2002)

\subsection{Zion}

At Zion, used nuclear fuel has not yet been loaded into dry storage canisters and transferred to an ISFSI. It is estimated that there will be 61 canisters containing 2226 used nuclear fuel assemblies (1019.4 MTHM) that were discharged from the Zion 1 and Zion 2 reactors (Leduc 2012).

Additional canisters containing GTCC low-level radioactive waste could be generated during the decommissioning of the Zion site. Ux Consulting (2012) states that the NAC International is providing four canisters to Zion for storage of GTCC low-level radioactive waste. The storage system that will be used at Zion is the NAC MAGNASTOR system (Docket No. 72-1031) with the TSC-37 canister, which holds 37 pressurized water reactor used nuclear fuel assemblies. The assemblies at Zion are all Zircaloy-clad. It is expected that the loading of the canisters and the MAGNASTOR system will start in 2013. The transportation cask that will be licensed to transport this used nuclear fuel is the NAC MAGNATRAN (Docket No. 71-9356). The application for a license for the MAGNATRAN is currently under review by the NRC. NAC anticipates that the certificate of compliance for the MAGNATRAN will be issued in 2013 (Ux Consulting 2012).

Figure 2-28 illustrates the number of used nuclear fuel assemblies at Zion, based on their discharge year. The oldest fuel was discharged in 1976 and the last fuel was discharged in 1997. The median discharge year of the fuel is 1987. 
Figure 2-29 illustrates the number of used nuclear fuel assemblies at Zion based on their burnup. The lowest burnup is $14.2 \mathrm{GWd} / \mathrm{MTHM}$ and the highest burnup is $55.1 \mathrm{GWd} / \mathrm{MTHM}$. The median burnup is $33.1 \mathrm{GWd} / \mathrm{MTHM}$. There are 36 used nuclear fuel assemblies at Zion with burnups greater than $45 \mathrm{GWd}$ /MTHM. These 36 fuel assemblies are classified by the NRC as high burnup used nuclear fuel. Ux Consulting (2012) states that for the MAGNATRAN transportation cask, all fuel with a burnup great than $45 \mathrm{GWd} / \mathrm{MTHM}$ will be canned in damaged fuel cans and that each TSC-37 canister can accommodate up to four damaged fuel cans.

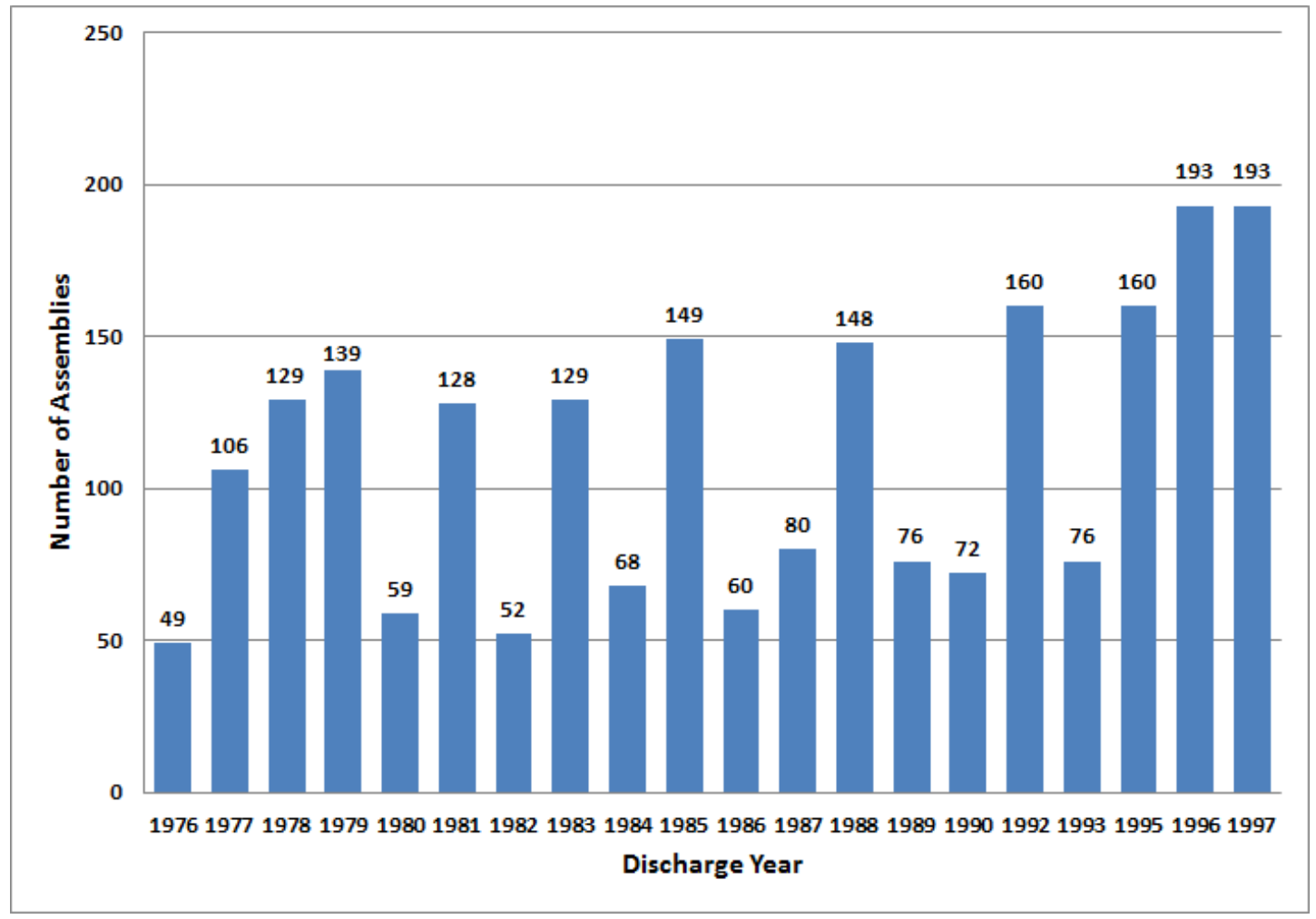

Figure 2-28. Zion Number of Assemblies versus Discharge Year (EIA 2002) 
Nuclear Fuels Storage and Transportation Planning Project A Preliminary Evaluation of Removing Used Nuclear Fuel From Nine Shutdown Sites April 30, 2013

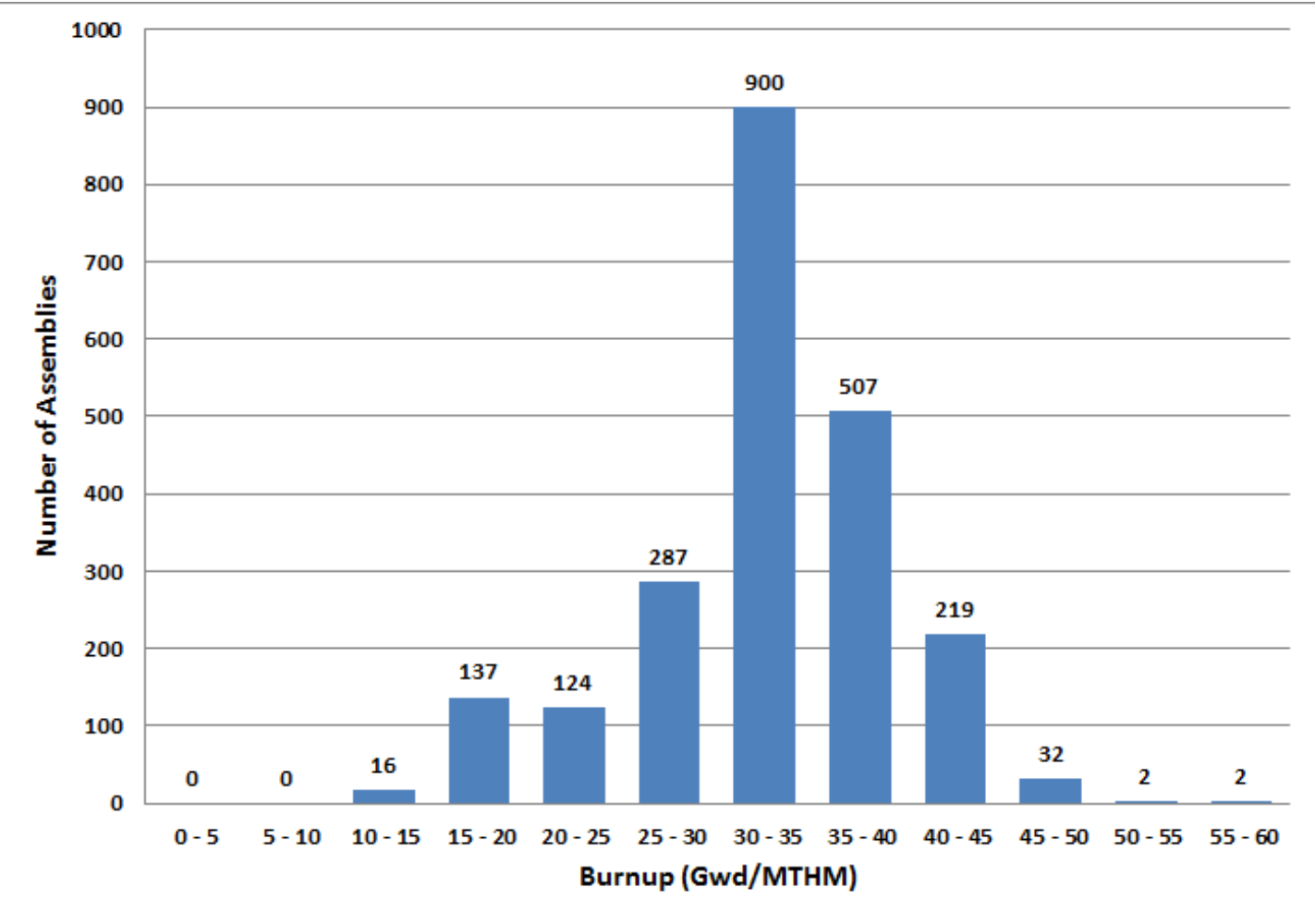

Figure 2-29. Zion Number of Assemblies versus Burnup (EIA 2002) 
Nuclear Fuels Storage and Transportation Planning Project A Preliminary Evaluation of Removing Used Nuclear Fuel From Nine Shutdown Sites 


\section{SITE CONDITIONS}

This section describes the conditions at each of the nine shutdown sites. The primary sources for the information presented in this section include site visits to the Maine Yankee, Yankee Rowe, and Connecticut Yankee sites; information provided by managers at the shutdown sites; Facility Interface Data Sheets compiled for DOE in 2005 (TriVis Incorporated 2005); Services Planning Documents prepared for DOE in 1993 and 1994; and Google Earth (Google 2012). Conditions outside of the nine shutdown sites are discussed in Section 4.

\subsection{Maine Yankee}

Figure 3-1 provides an aerial view of the Maine Yankee site, where the Maine Yankee reactor and associated structures have been removed. Electrical power is available at the Maine Yankee ISFSI; however, mobile equipment such as cranes would be required to unload the NAC-UMS vertical concrete storage casks used at Maine Yankee and to load the NAC-UMS UTC transportation cask that is licensed to transport the Maine Yankee used nuclear fuel and GTCC low-level radioactive waste. In addition, a transfer cask would be required to perform this transfer.

An onsite rail spur exists at Maine Yankee (Figure 3-2). This spur is designated as track class $1^{3}$ and connects to the Maine Eastern Railroad, which is designated as track class 2. During decommissioning, 238 radioactive and nonradioactive waste shipments were made over the period 2000 to 2005 using this rail spur (EPRI 2005). There appears to be sufficient room within the Owner Controlled Area to permit staging of railcars. However, the rail spur has been paved over in spots (see Figure 3-3), and refurbishment and a heavy load assessment would be required prior to use.

A barge dock that exists at Maine Yankee (Figure 3-4) would provide access to the Atlantic Ocean. The Maine Yankee steam generators, pressurizer, and reactor pressure vessel were shipped offsite using this barge dock (Wheeler 2002, Feigenbaum 2005). The three steam generators weighed 356 tons each (491 tons each when the shielding and carriage assembly are included) and the pressurizer weighed 100 tons (Radwaste Solutions 2000). These components were transported to Memphis, Tennessee for decontamination (Radwaste Solutions 2000). The reactor pressure vessel package weighed 1175 tons and was transported to the Barnwell, South Carolina low-level radioactive waste disposal facility (Feigenbaum 2005). In addition, EPRI (2005) states that the site's main power transformers were shipped offsite by barge. The barge dock is approximately 10 feet above the water and the depth of the water is about 6 feet at high tide (TOPO 1993a). The barge dock and access road were last used in 2003 (TriVis Incorporated 2005), are not being maintained post-decommissioning, and would likely need refurbishment prior to use.

\footnotetext{
${ }^{3}$ Track class is a measure of track quality. In 49 CFR 213, the Federal Railroad Administration has categorized all track into nine classes (1-9), segregated by maximum allowable operating speed.
} 


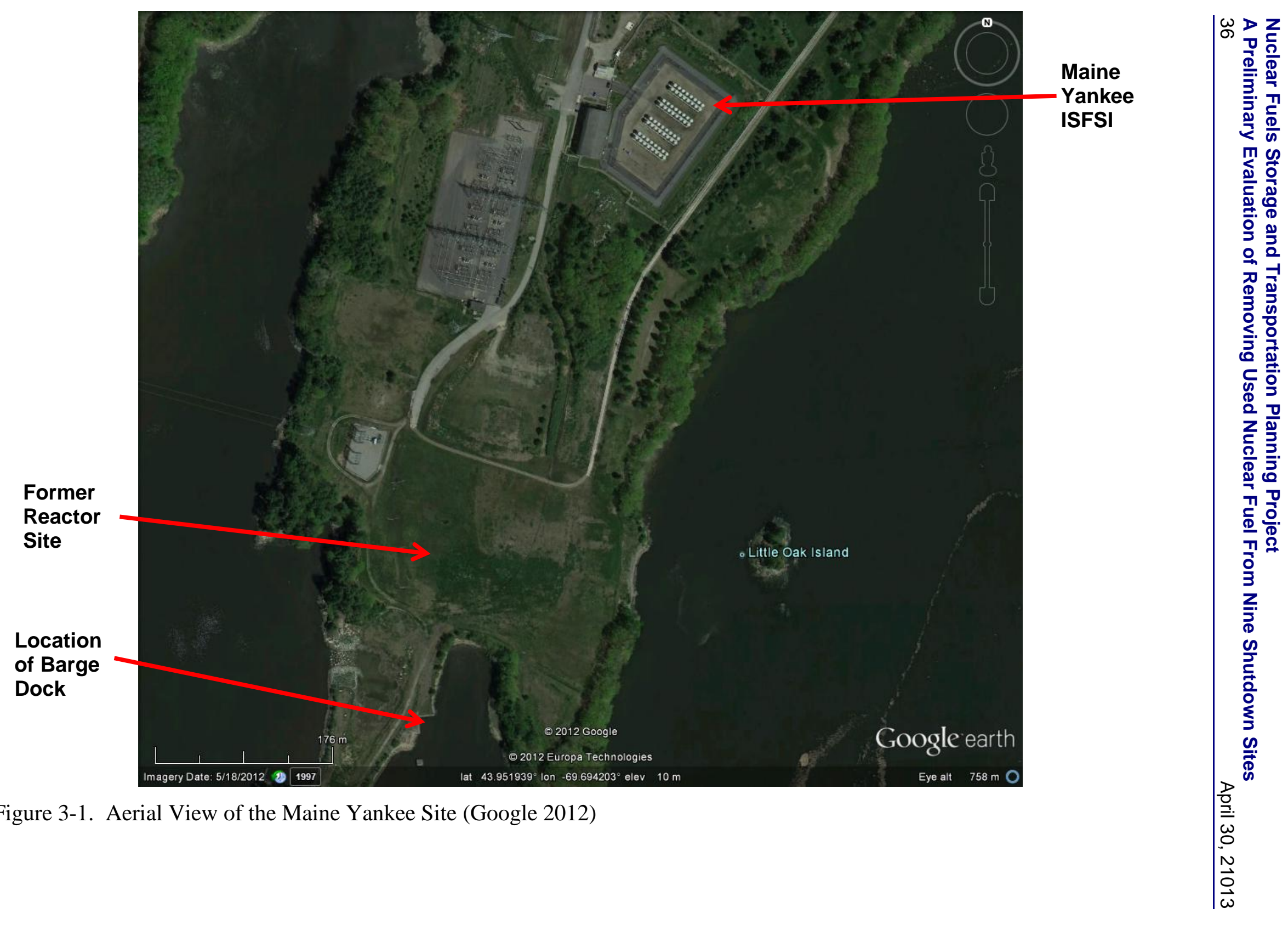




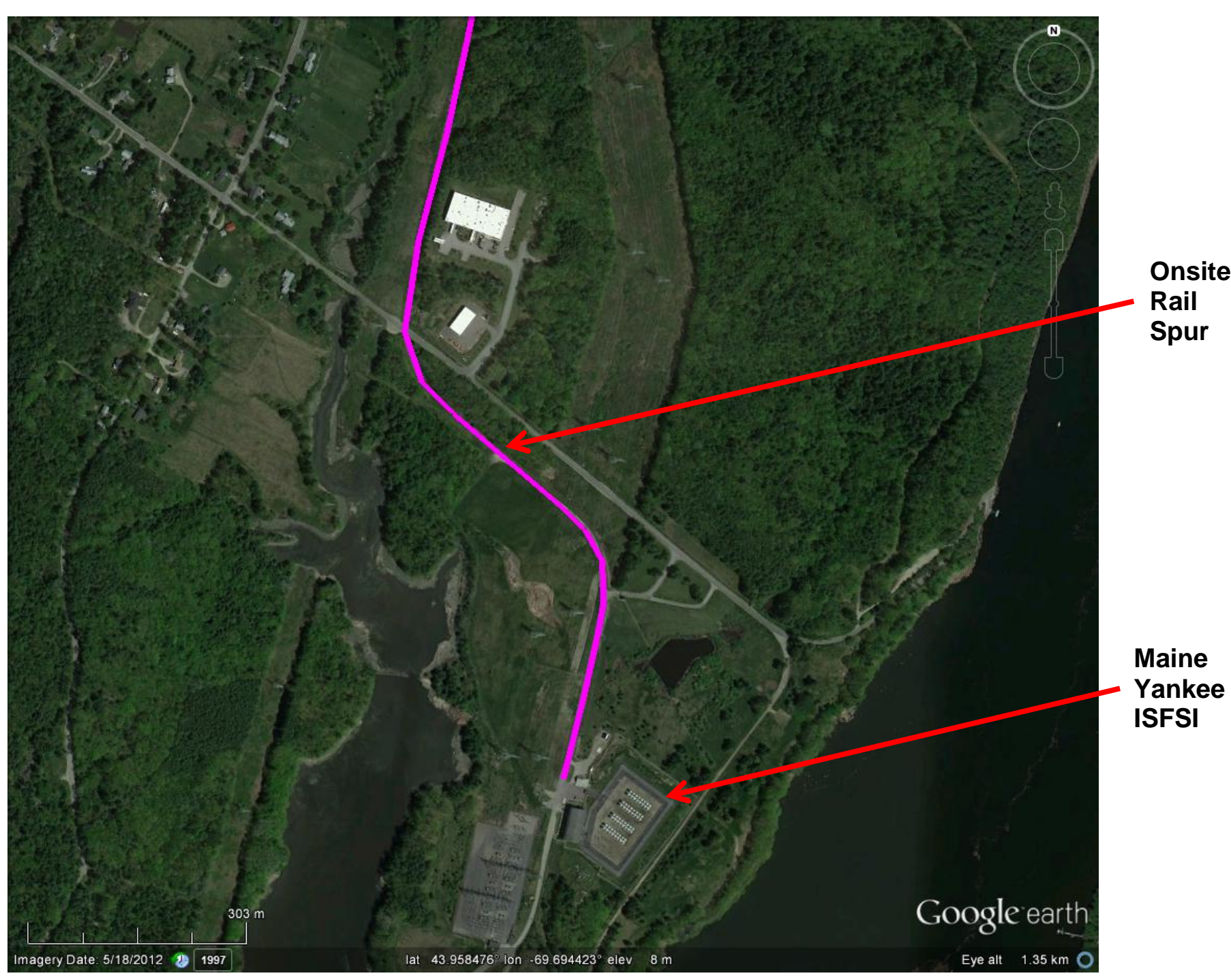

Figure 3-2. Onsite Railroad Spur at the Maine Yankee Site (Google 2012) 


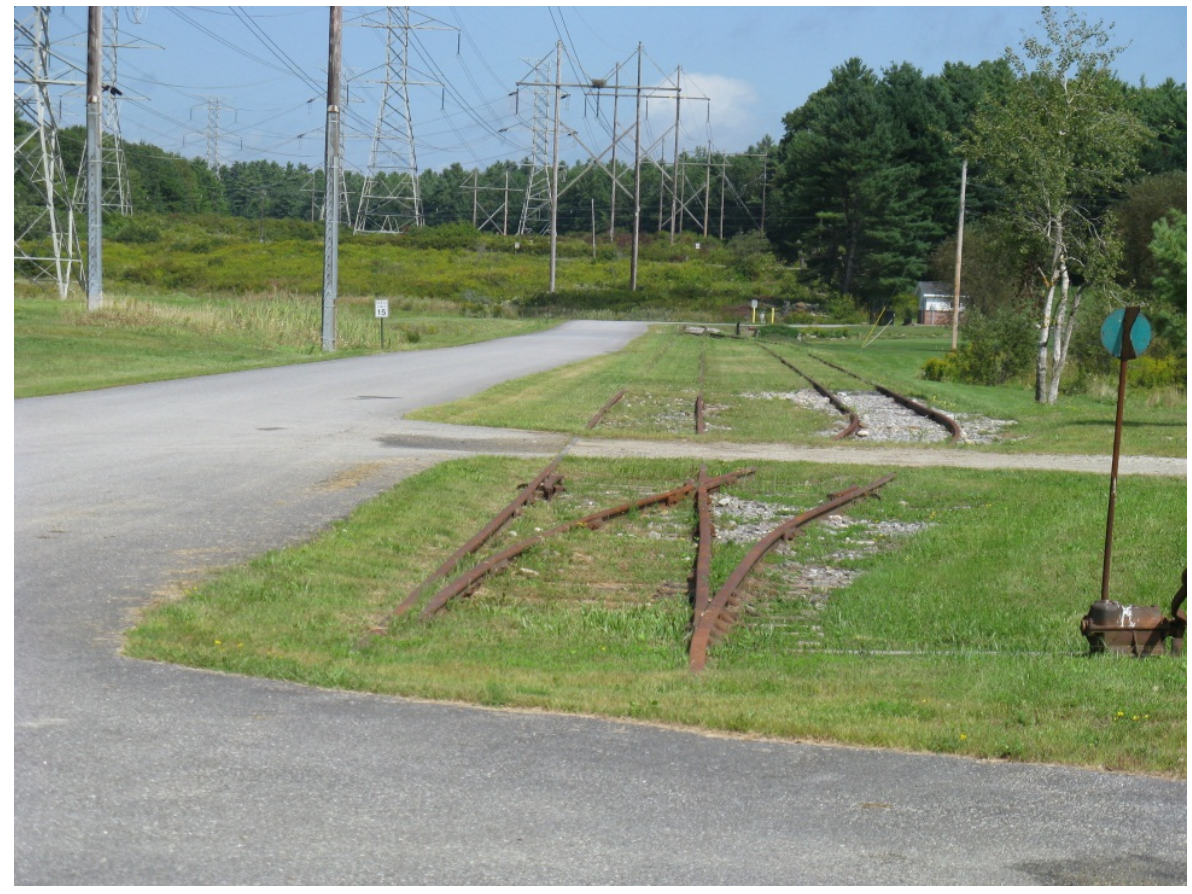

Figure 3-3. Paved-over Railroad Tracks at the Maine Yankee Site

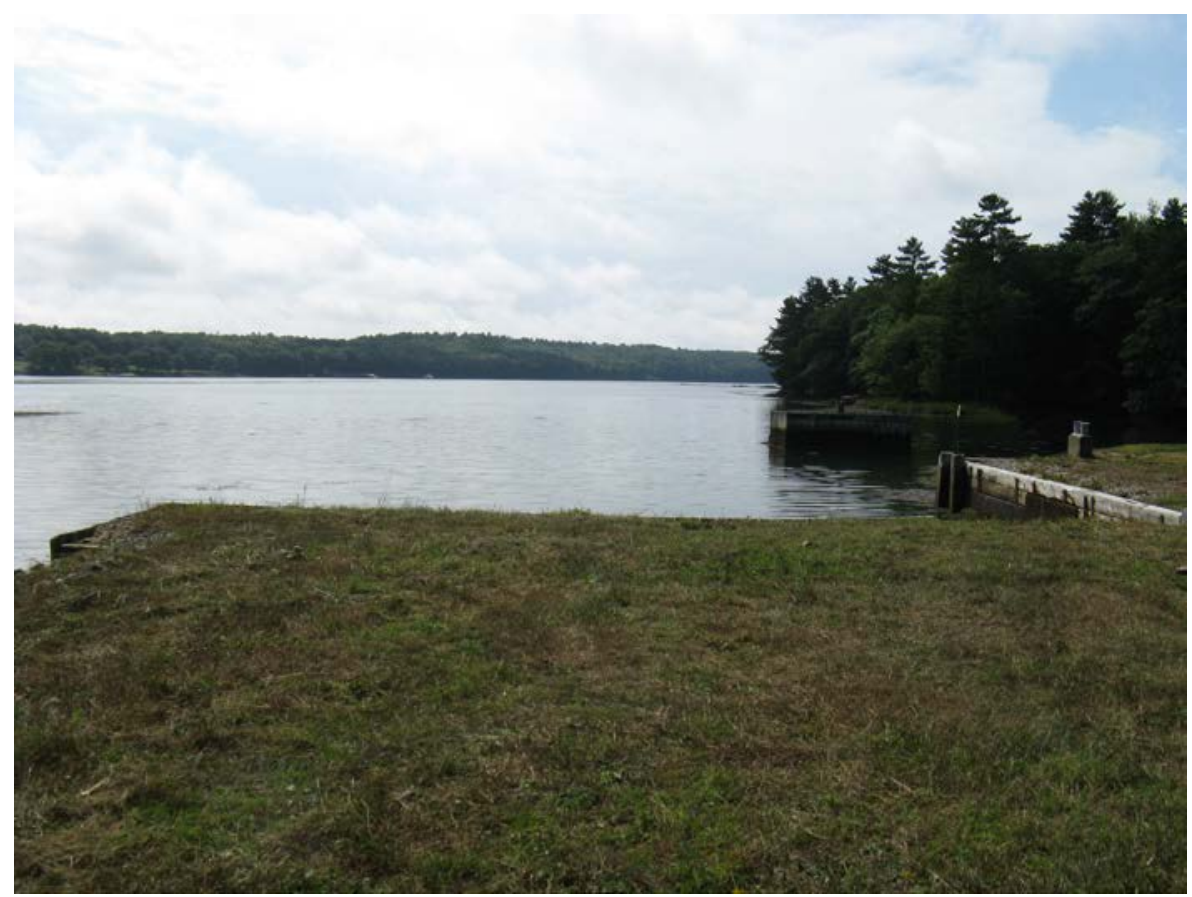

Figure 3-4. Barge Dock at the Maine Yankee Site 


\subsection{Yankee Rowe}

Figure 3-5 provides an aerial view of the Yankee Rowe site, where the reactor and associated structures have been removed. Electrical power is available at the Yankee Rowe ISFSI; however, mobile equipment such as cranes would be required to unload the NAC-MPC vertical concrete storage casks used at Yankee Rowe and to load the NAC-STC transportation cask that is licensed to transport the Yankee Rowe used nuclear fuel and GTCC low-level radioactive waste. In addition, a transfer cask would be required to perform this transfer.

There is no barge access or direct rail access at the Yankee Rowe site. The nearest offsite barge facility is located in Albany, New York, a distance of 50 miles from Yankee Rowe (TriVis Incorporated 2005). Yankee Rowe had direct rail service, but the rail spur to the site was removed in the early 1970s and cannot be reinstalled because the construction of the Cockwell (formerly Bear Swamp) Pumped Storage Plant resulted in submersion of the rail line to Yankee Rowe (TOPO 1993b). The nearest railhead is at the east end of the Hoosac Tunnel, a distance of about 7.5 miles from the Yankee Rowe site. The Pan Am Southern rail line at the Hoosac Tunnel is designated as track class 3. Heavy haul truck transport would be required to reach this railhead. This would require constructing an onsite access road from the Yankee Rowe ISFSI to the Sherman Dam and obtaining authorization for the heavy haul vehicles to cross the dam. The Yankee Rowe reactor pressure vessel and steam generators were removed from the site using this heavy haul route. The Sherman Dam is owned and operated by TransCanada Hydro Northeast Inc. Based on the experience during decommissioning, TransCanada would need to be notified of the intent to use the roadway and bridge to move heavy loads across the dam; the load evaluation used for the removal of the reactor pressure vessel and steam generators would have to be verified and modified if necessary; and an engineering walk down of the roadway and bridge would be needed to confirm that there had been no changes or deterioration that would invalidate the previous load evaluation. EPRI (1998) states that the spillway bridge on the Sherman Dam was replaced prior to shipping the reactor pressure vessel and the slope stability along the roadway, as well as the roadway culverts, was assessed for the loaded cask transport conditions. The reactor pressure vessel cask package weighed 365 tons with saddle and tie downs (EPRI 1998). At the Hoosac Tunnel rail crossing, the reactor pressure vessel package was transferred from the roadway transporter to a TransAlta CAPX 1001 rail car. The railcar was equipped with a lateral shift mechanism that enabled handlers to move the cargo left or right up to 12 inches (Lessard 2000). The loaded gross weight of the railcar and cask was 1,122,700 lb. (EPRI 1998). The reactor pressure vessel was then transported to the Barnwell, South Carolina low-level radioactive waste disposal facility (Lessard 2000). During the trip to Barnwell, South Carolina, the lateral shift mechanism had to be used on six separate occasions to maneuver around structures or other rail cars along the route (Lessard 2000). These shifts ranged from 3 to 12 inches (Lessard 2000). 


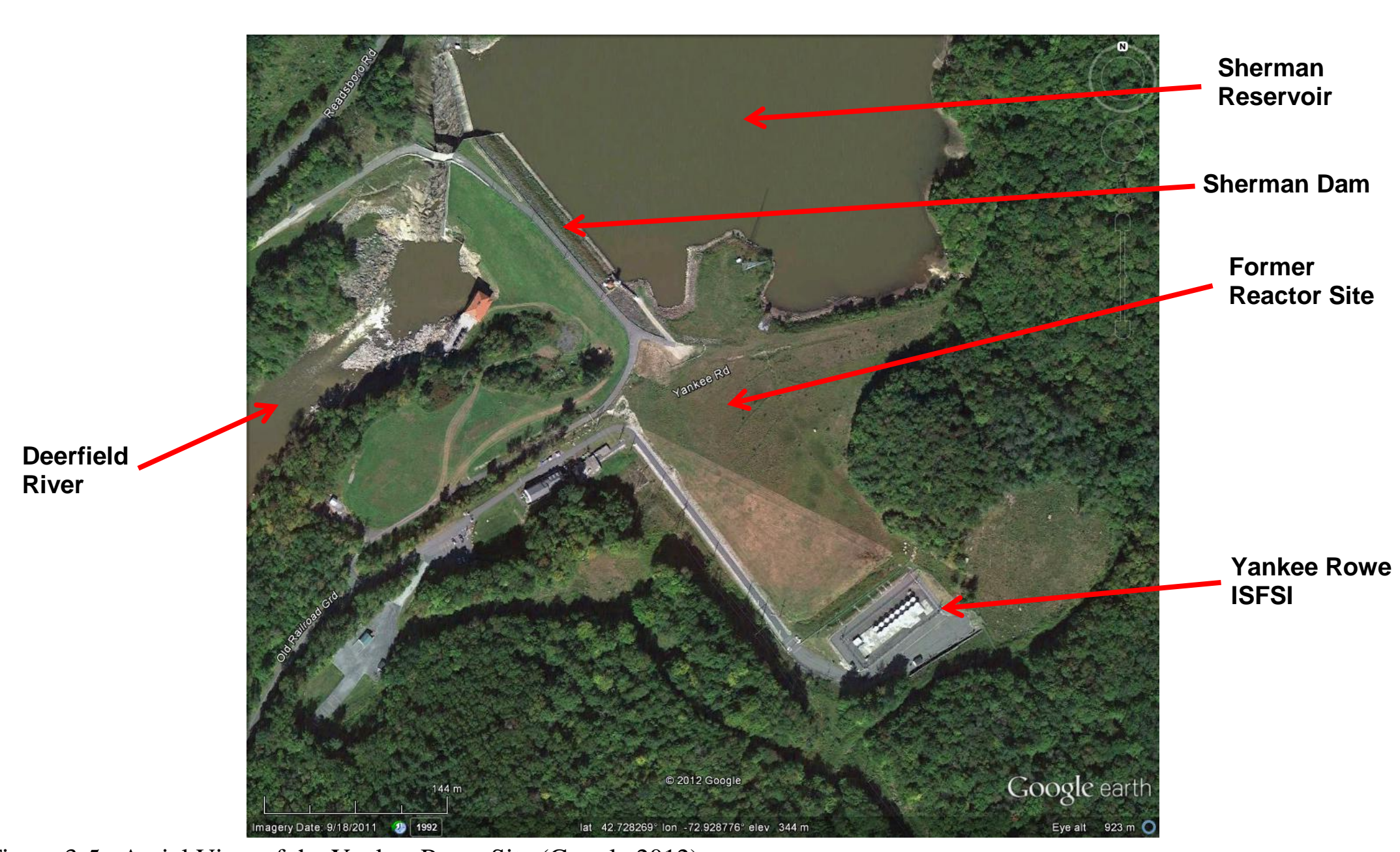

Figure 3-5. Aerial View of the Yankee Rowe Site (Google 2012)

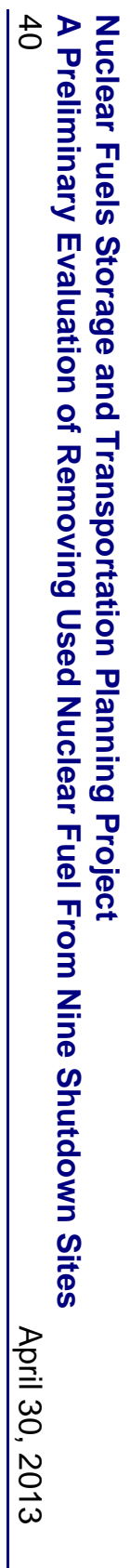




\subsection{Connecticut Yankee}

Figure 3-6 provides an aerial view of the Connecticut Yankee site, where the reactor and associated structures have been removed. Electrical power is available at the Connecticut Yankee ISFSI; however, mobile equipment such as cranes would be required to unload the NAC-MPC vertical concrete storage casks used at Connecticut Yankee and to load the NAC-STC transportation cask that is licensed to transport the Connecticut Yankee used nuclear fuel and GTCC low-level radioactive waste. In addition, a transfer cask would be required to perform this transfer. There are two transfer casks stored at the Connecticut Yankee ISFSI, but they would require refurbishment prior to use.

There is no onsite rail access at Connecticut Yankee. The nearest railhead is in Portland, Connecticut near Middletown, Connecticut, about 12 miles from the Connecticut Yankee ISFSI. To reach this railhead, heavy haul truck transport would be required. The Connecticut Yankee pressurizer and steam domes ${ }^{4}$ were removed from the site using this heavy haul route. The rail line at Portland is designated as track class 1 and connects to the Providence and Worcester Railroad in Middletown, Connecticut after crossing the Connecticut River. The condition of this bridge is unknown. The Providence and Worcester rail line in Middletown, Connecticut is designated as track class 2 .

An onsite barge slip at Connecticut Yankee is located at the northeast end of the cooling water discharge canal (see Figures 3-6 and 3-7) and is about 0.9 miles from the Connecticut Yankee ISFSI. This slip provides access to the Connecticut River and Atlantic Ocean (TOPO 1993c). The barge slip and cooling water discharge canal were used to ship the reactor pressure vessel, steam generators, and transformer offsite (EPRI 2006, Connecticut Yankee 2012). At the time that the reactor pressure vessel was shipped, the cooling water discharge canal had silted up and the canal was dredged before the reactor pressure vessel was shipped (EPRI 2006). The onsite barge sidings and docks were removed after decommissioning and would have to be reconstructed prior to use. It may also be necessary to dredge the cooling water discharge canal to ensure that it is deep enough for the barges.

\footnotetext{
${ }^{4}$ The steam dome is the upper portion of the steam generator (EPRI 2006).
} 


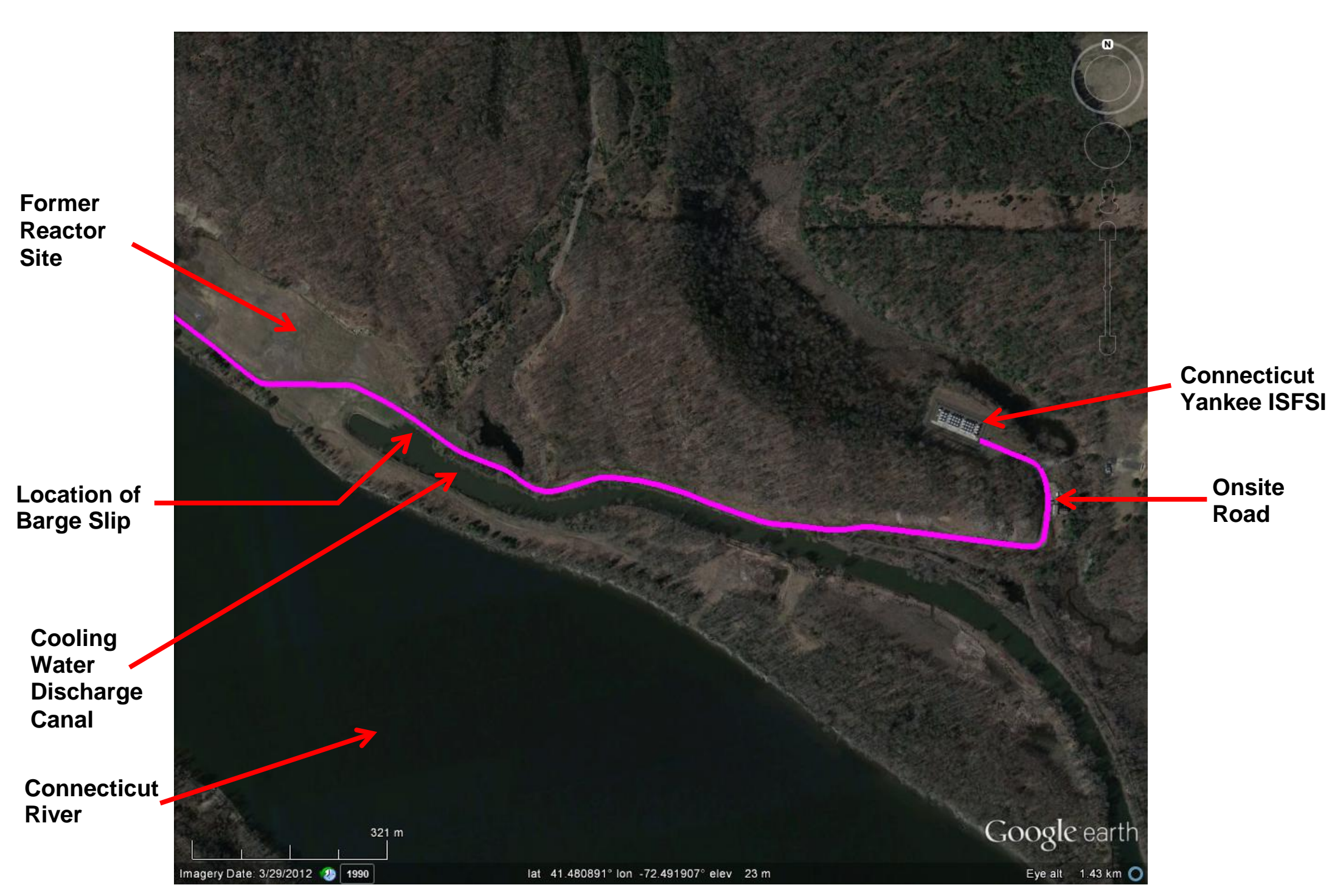

Figure 3-6. Aerial View of the Connecticut Yankee Site (Google 2012)

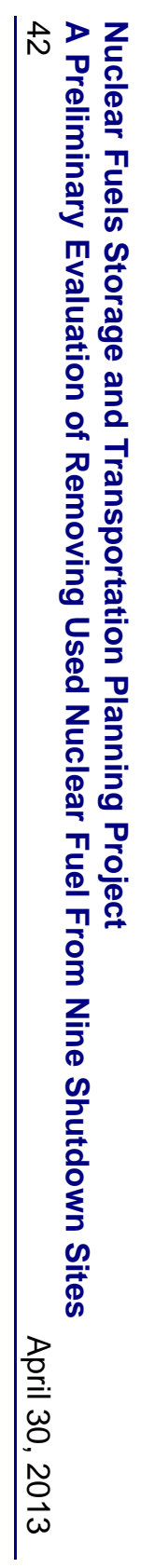




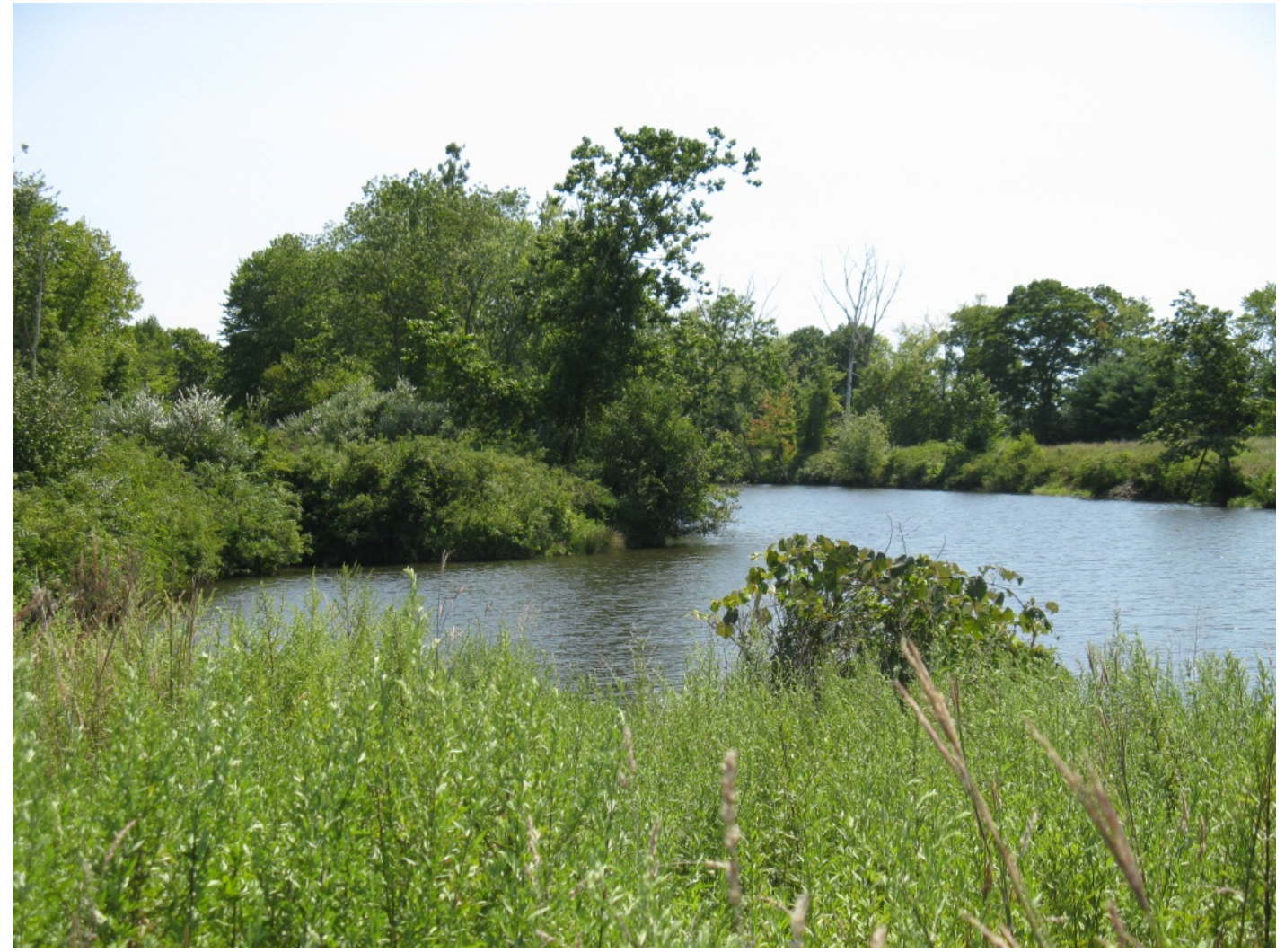

Figure 3-7. Barge Slip at the Connecticut Yankee Site

\subsection{Humboldt Bay}

Figure 3-8 provides an aerial view of the Humboldt Bay site, which is being decommissioned, with closure anticipated in 2015. Electrical power is available at the Humboldt Bay ISFSI; however, mobile equipment such as cranes or special lifting devices would be required to remove the HI-STAR HB casks containing the Humboldt Bay used nuclear fuel or GTCC low-level radioactive waste from their below-grade vaults. The HI-STAR HB casks are licensed for both the storage and transport of the Humboldt Bay used nuclear fuel. Consequently, a transfer cask is not required at the Humboldt Bay site. The HI-STAR HB casks were moved to the Humboldt Bay site using heavy haul trucks.

The Humboldt Bay site has not been served by rail since November 1998, when the Federal Railroad Administration issued Emergency Order 21, which closed the Northwestern Pacific Railroad from Arcata, California (mile post 295.5) to mile post 63.4 between Schellville and Napa Junction, California, for failure to meet federal safety standards (63 FR 67976-67979). In May 2011, the Federal Railroad Administration allowed the Northwestern Pacific Railroad to reopen as far north as mile post 62.9 near Windsor, California (76 FR 27171-27172), about 220 miles south of the Humboldt Bay site. The nearest railhead is located in Redding, California, a distance of about 160 miles from Humboldt Bay. To reach this railhead, heavy haul truck transport would be required on U.S. Highway 101 and State Route 299. The Union Pacific rail line in the vicinity of Redding is designated as track class 4.

During the decommissioning of Humboldt Bay, several heavy haul truck routes have been used: 
- U.S. Highway 101 south to California State Route 20 to Interstate 5

- U.S. Highway 101 north to U.S. Highway 199 to Interstate 5

- U.S. Highway 101 south to California State Route 299 to Interstate 5.

These routes range in length from about 160 to 230 miles. In addition to these routes, representatives of Pacific Gas and Electric Company (PG\&E) have stated that a heavy haul truck route that used U.S. Highway 101 south to State Route 36 to Interstate 5 (160 miles) would be unacceptable. $^{5}$

There is also no onsite barge access at the Humboldt Bay site (TriVis Incorporated 2005, TOPO 1993d). Although there is no onsite barge access, barges were recently used to move 10 Wartsila engines weighing 680,000 lb. each and 10 generators weighing 165,000 lb. each to the Fields Landing Terminal, which is about 2 miles from the Humboldt Bay Generating Station ${ }^{6}$ (AC\&T 2011). Heavy haul trucks then moved the engines and generators from the terminal to the Humboldt Bay Generating Station.

${ }^{5}$ Williams JR. 2013. Email message from L Sharp (Pacific Gas and Electric Company) to JR Williams (U.S. Department of Energy), “RE: PG\&E Comments to DOE Draft Report,” February 25, 2013.

${ }^{6}$ Maheras SJ. 2012. Email message from A Richards (Senior Project Manager/Special Projects, Bragg Crane \& Rigging) to SJ Maheras (Pacific Northwest National Laboratory), “Andy Richards / Bragg Crane \& Rigging,” October 17, 2012. 


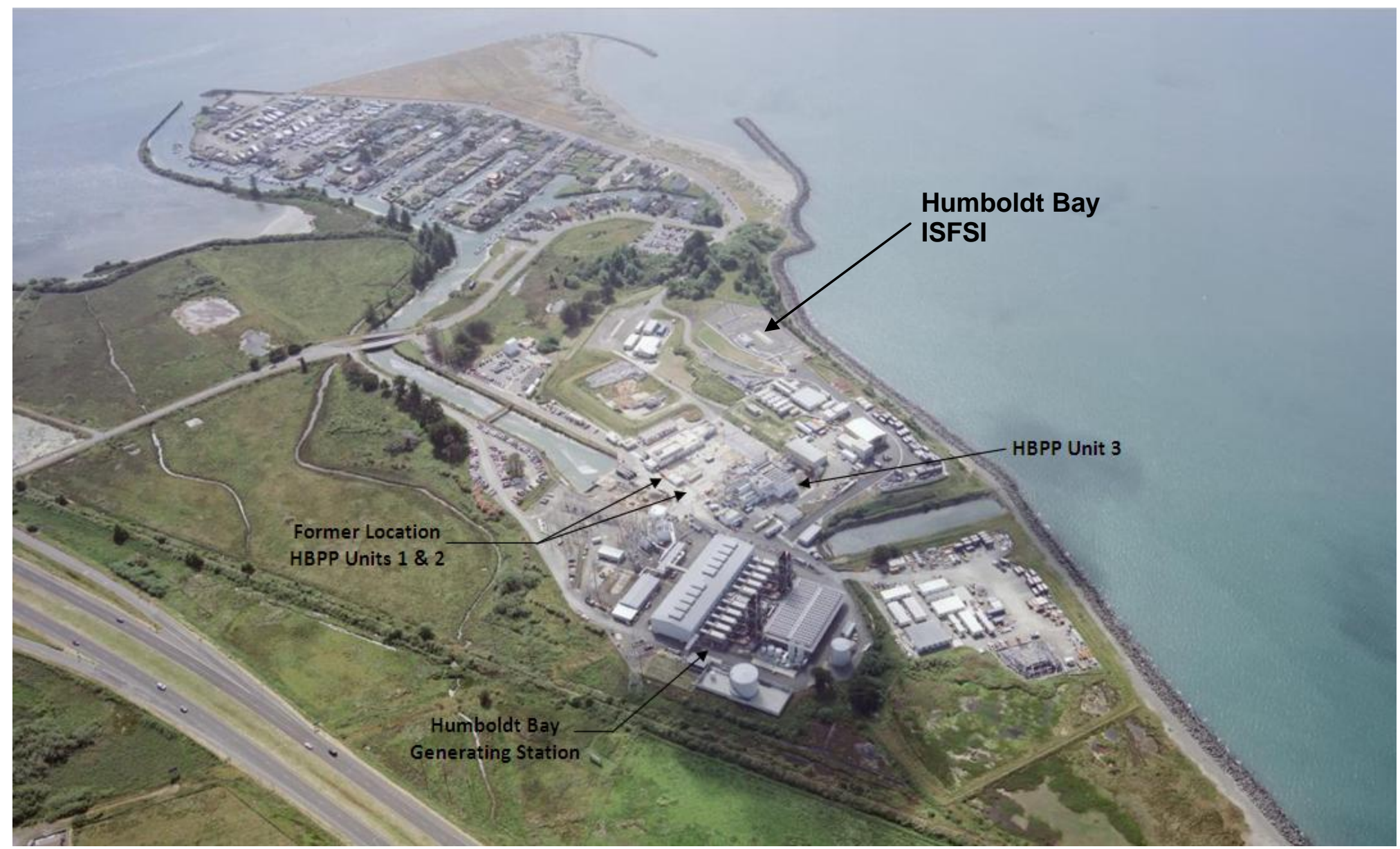

Photo courtesy of Humboldt Bay

Figure 3-8. Aerial View of Humboldt Bay Site 


\subsection{Big Rock Point}

Figure 3-9 provides an aerial view of the Big Rock Point site, where the reactor and associated structures have been removed. Electrical power is available at the Big Rock Point ISFSI; a transfer cask, lift unit, horizontal transfer system and J-skid were present at the ISFSI in 2010 (NRC 2010). Herron (2010) stated that the equipment needed to transfer used nuclear fuel and GTCC low-level radioactive waste in W74 canisters from the W150 storage casks to the TS125 transportation cask is in place, is tested on a periodic basis, and preventative maintenance is performed. The TS125 transportation cask is licensed to transport the Big Rock Point used nuclear fuel; however, the TS125 transportation cask is not licensed for the transport of GTCC low-level radioactive waste.

There is no onsite rail access at the Big Rock Point site (TriVis Incorporated 2005). Gaylord, Michigan was used as the railhead for shipping the reactor pressure vessel (565,000 lb.) from Big Rock Point to the Barnwell, South Carolina low-level radioactive waste disposal facility. The distance from Big Rock Point to Gaylord is about 52 miles (Petrosky 2004). The Lake State Railway in the vicinity of Gaylord is designated as track class 2. Petoskey, Michigan, about 13 miles from Big Rock Point (TOPO 1994a), was used as the railhead for shipping the steam drum (200,000 lb.) to the Energy Solutions low-level radioactive waste disposal facility in Clive, Utah (Tompkins 2006). The Great Lakes Central Railroad is designated as track class 1 in the vicinity of Petoskey. To reach these railheads, heavy haul truck transport would be required. Herron (2010) states that the heavy haul roadway no longer exists on the site and that the road from the ISFSI to the highway was not built to support heavy haul transfers, and may need to be rebuilt or enhanced.

An onsite barge facility (see Figure 3-9) was used during construction and would have to be reestablished. This would likely involve grading and spreading gravel. In addition, Lake Michigan is subject to freezing in the Big Rock Point area (TOPO 1994a), which could limit operations. 


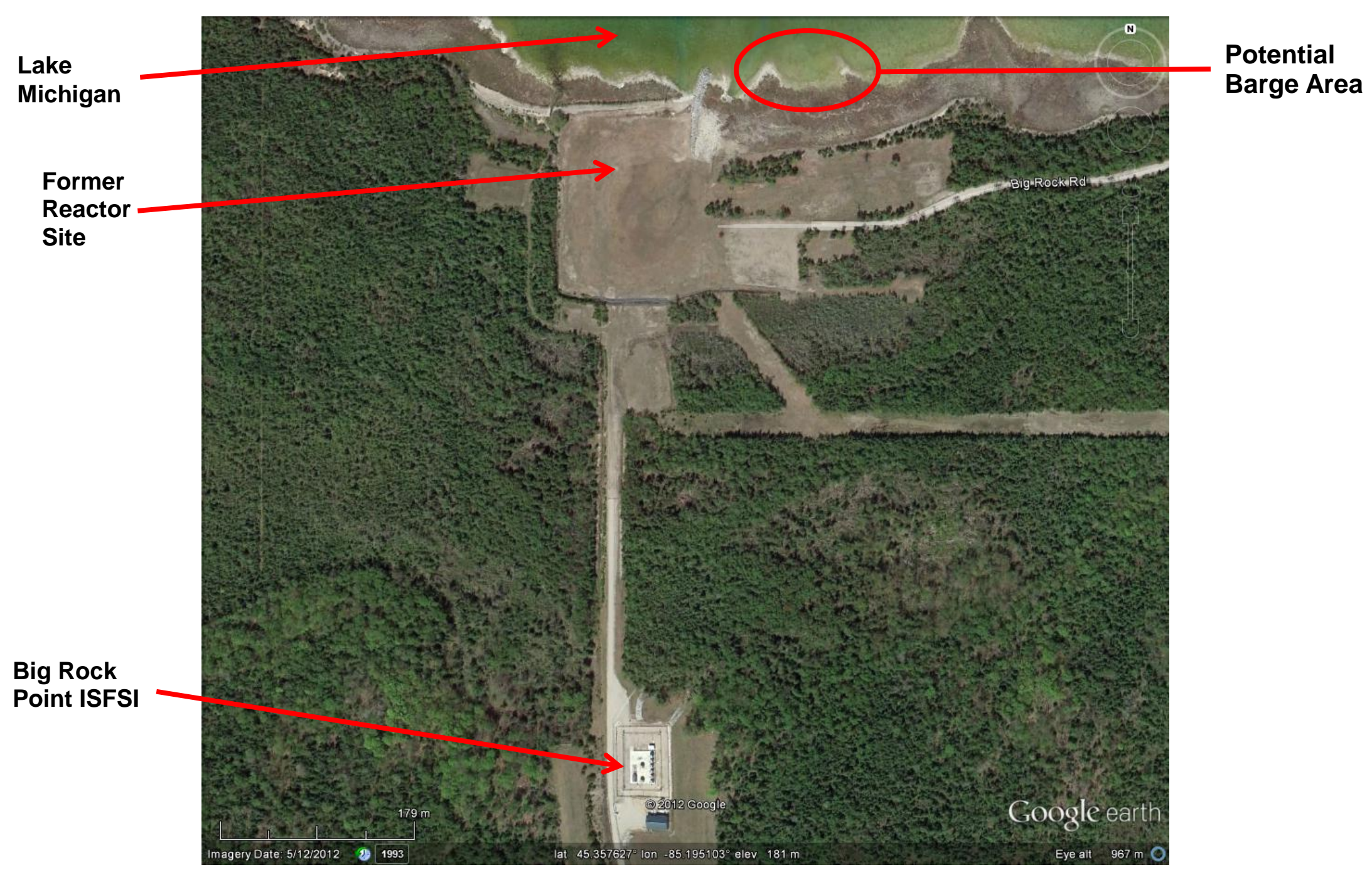

Figure 3-9. Aerial View of Big Rock Point Site (Google 2012) 


\subsection{Rancho Seco}

Figure 3-10 provides an aerial view of the Rancho Seco site. The reactor building equipment and spent nuclear fuel pool have been decommissioned and removed, but the cooling towers, reactor containment building, and other associated structures remain onsite. Low-level radioactive waste is also stored onsite. Electrical power is available at the Rancho Seco ISFSI; however, mobile equipment such as cranes would be required to unload the canisters from the NUHOMS reinforced concrete horizontal storage modules and to load the MP187 transportation cask that is licensed to transport the Rancho Seco used nuclear fuel. The MP187 transportation cask is not licensed for the transport of GTCC low-level radioactive waste.

There is no onsite barge access at the Rancho Seco site (TriVis Incorporated 2005) and Rancho Seco is not near a navigable waterway (NAC 1991a). A 1-mile-long onsite rail spur exists at Rancho Seco and runs near the ISFSI (about 100 feet) (see Figure 3-10). Rancho Seco owns the rail spur that provides access to the Union Pacific's mainline. The Union Pacific mainline is designated as track class 5. California State Route 104 crosses the rail spur (see Figure 3-10). The rail spur was not maintained after shutdown in 1989; but was restored to operating condition in the early 2000s to support decommissioning. During decommissioning, this rail spur was used to transport four reactor coolant pumps (50 tons each), the pressurizer (150 tons), and two steam generators (550 tons each) to the Energy Solutions low-level radioactive waste disposal facility in Clive, Utah (Johnson 2006). The rail spur was last maintained and certified in 2008; but is not being maintained. Past restoration of the rail spur to pass inspection was a relatively inexpensive, straightforward project. ${ }^{7}$

\footnotetext{
${ }^{7}$ Ross SB. 2012. E-mail from ET Ronningen (Superintendent, Rancho Seco Assets Power Generation, Sacramento Municipal
} Utility District) to SB Ross (Pacific Northwest National Laboratory), “Re:Request for Info,” September 17, 2012. 


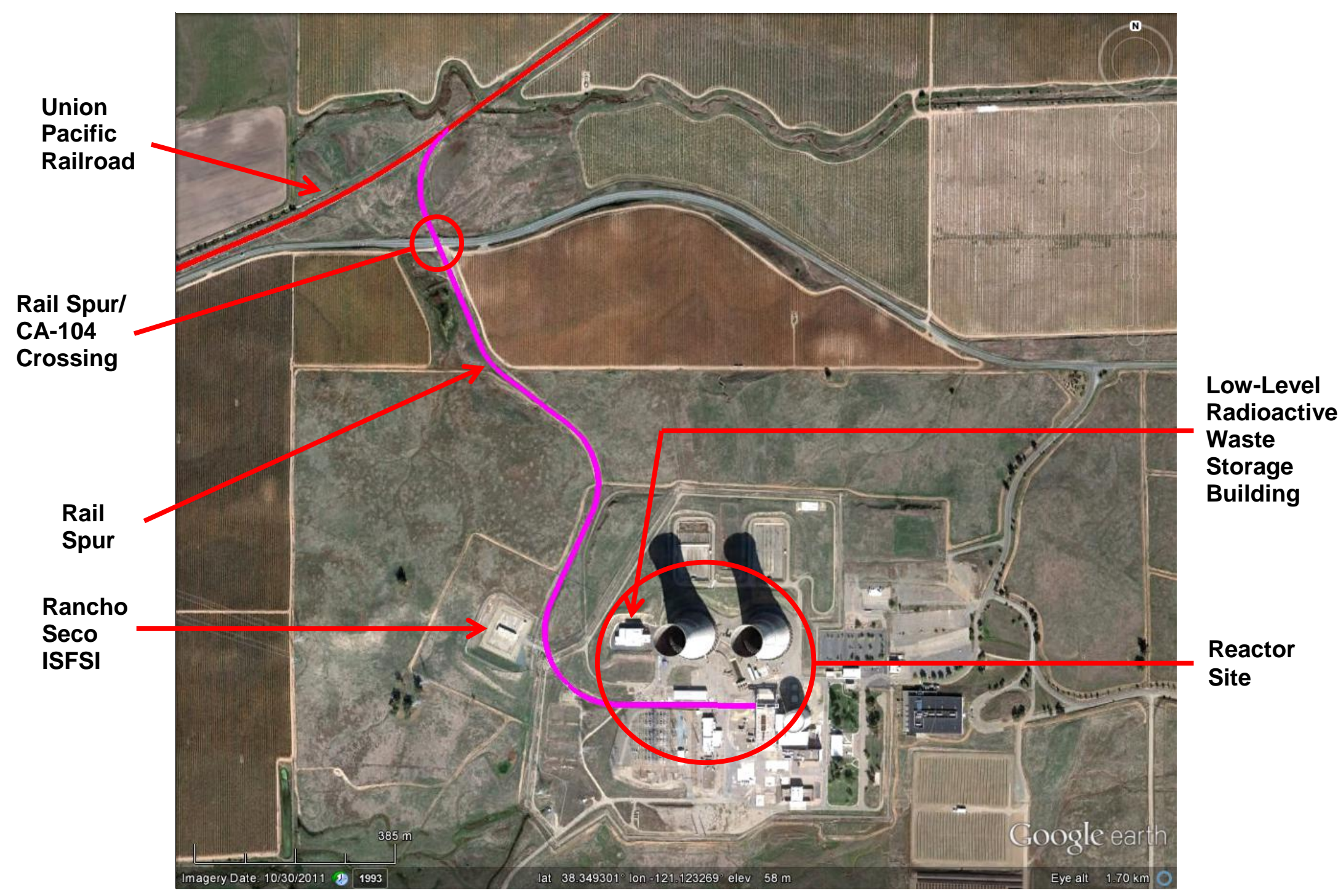

Figure 3-10. Aerial View of Rancho Seco Site (Google 2012) 


\subsection{Trojan}

Figure 3-11 provides an aerial view of the Trojan site, where the reactor and associated structures have been removed. Electrical power is available at the Trojan ISFSI; however, mobile equipment such as cranes would be required to unload the TranStor vertical concrete storage overpacks containing the Holtec multipurpose canisters used at Trojan and to load the HI-STAR 100 transportation casks. The HI-STAR 100 transportation cask is licensed to transport the Trojan used nuclear fuel. A transfer cask, transfer station, and air pad system are also located at the Trojan ISFSI.

The Portland and Western Railroad rail line passes through the Trojan site approximately 700 feet from the Trojan ISFSI (TriVis Incorporated 2005). This rail line is designated as track class 2. A rail spur formerly came into the protected area (NAC 1991b). This was disconnected, but could be rebuilt in preparation for shipping used nuclear fuel. ${ }^{8}$

A barge slip is located on the Trojan site about 3000 feet south of the Trojan ISFSI. The barge slip provides for roll-on/roll-off capability. During decommissioning, Trojan shipped four steam generators, the pressurizer, and the reactor pressure vessel from this barge slip to the US Ecology low-level radioactive waste disposal facility near Richland, Washington. ${ }^{8}$ The steam generator packages weighed 450 tons each and the pressurizer package weighed 125 tons (Lackey and Kelly 1996, 1997). The reactor pressure vessel package weighed 1000 tons (Radwaste Magazine 1999). The barge slip is not being maintained ${ }^{8}$ and dredging is usually required prior to use. There is no crane or other permanently installed handling or lifting equipment at the barge slip.

\footnotetext{
${ }^{8}$ Ross SB. 2012. Email message from JP Fischer (Trojan ISFSI Manager, Portland General Electric Company) to SB Ross (Pacific Northwest National Laboratory), “Re: Request for Info,” September 17, 2012.
} 


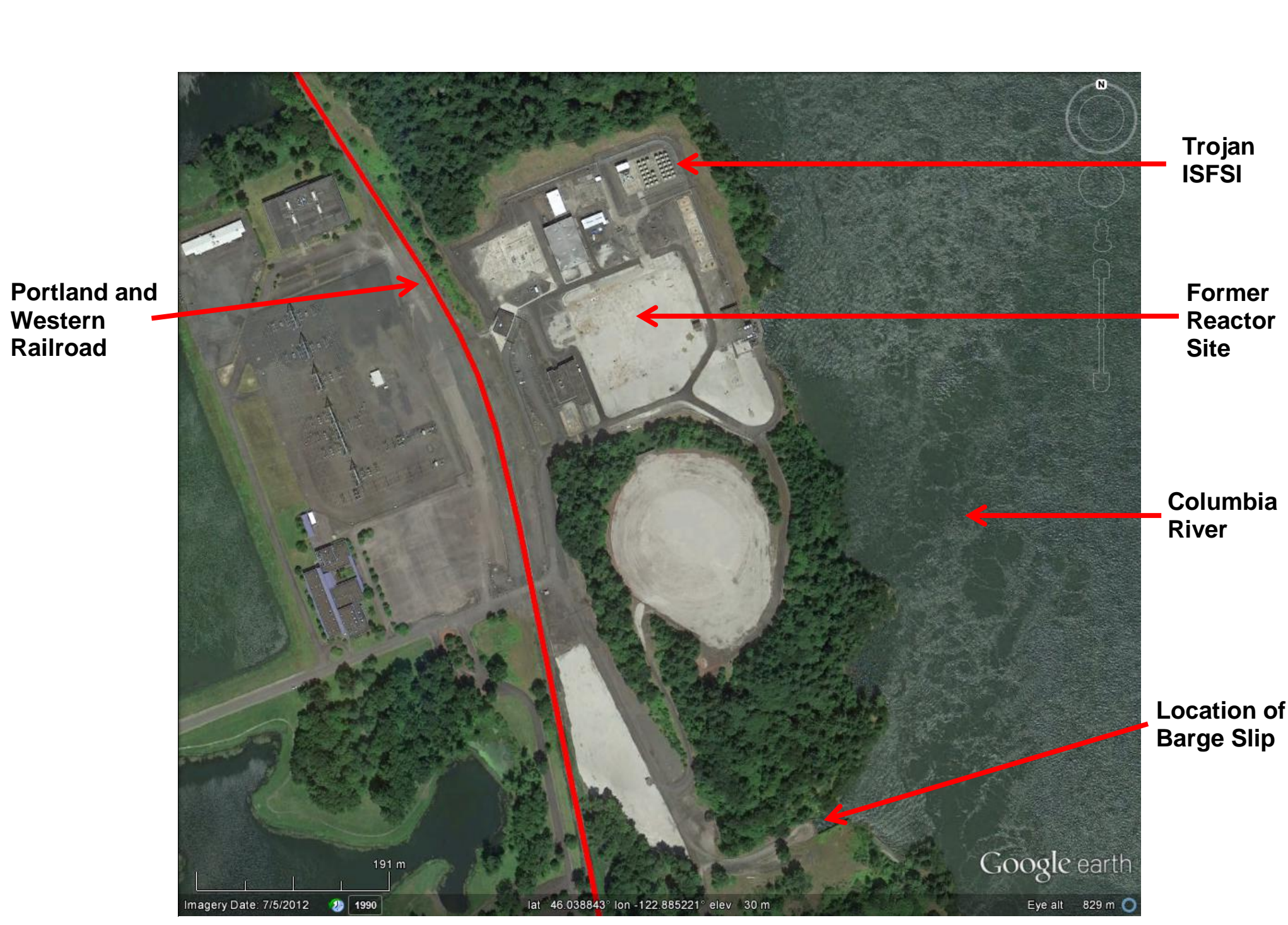

Figure 3-11. Aerial View of Trojan Site (Google 2012) 


\subsection{La Crosse}

Figure 3-12 provides an aerial view of the La Crosse site, where the nuclear power plant is being decommissioned. As seen in Figure 3-12 the La Crosse ISFSI is located south of the La Crosse reactor site and the Genoa \#3 coal-fired power plant. Electrical power is available at the La Crosse ISFSI; however, mobile equipment such as cranes would be required to unload the NAC-MPC vertical concrete storage casks used at La Crosse and to load the NAC-STC transportation cask that is licensed to transport the La Crosse used nuclear fuel. In addition, a transfer cask would be required to perform this transfer.

Rail access to the La Crosse site is provided by the BNSF Railroad that is east of the La Crosse ISFSI. This rail line is designated as track class 4. La Crosse does not have an active onsite rail spur. ${ }^{9}$ An old rail spur could be rebuilt and the BNSF Railroad has a siding at the north end of the site that could easily be extended. ${ }^{9}$ In 2007, rail was used to transport the La Crosse reactor pressure vessel to the Barnwell, South Carolina low-level radioactive waste disposal facility (Radwaste Solutions 2007). The reactor pressure vessel was transported on a specially designed 20-axle railcar and the shipment weighed 310 tons.

Onsite barge access is available about 0.2 miles north of the La Crosse reactor site. The dock area is approximately 500 feet long by 100 feet wide with a minimum 9-foot water depth (TOPO 1993e). The barge facility is located on the Mississippi River and has direct access to the shipping channel. The barge facility is routinely used for the removal of covers from coal barges using a portable crane. The coal is subsequently unloaded several hundred yards downstream adjacent to the Genoa \#3 coal-fired power plant. A large number of barge mooring/securing posts are available. Barge service is not available December through February and is limited by local weather conditions (TOPO 1993e). Mobile rental cranes of the required capacity are available (TriVis Incorporated 2005). TOPO (1993e) reports that dredging or other dock area refurbishment is likely to be required.

\footnotetext{
${ }^{9}$ Ross SB. 2012. Email message from DG Egge (Plant Manager, LACBWR, Dairyland Power Cooperative) to SB Ross (Pacific
} Northwest National Laboratory), “Re: La Crosse Information,” October 17, 2012. 


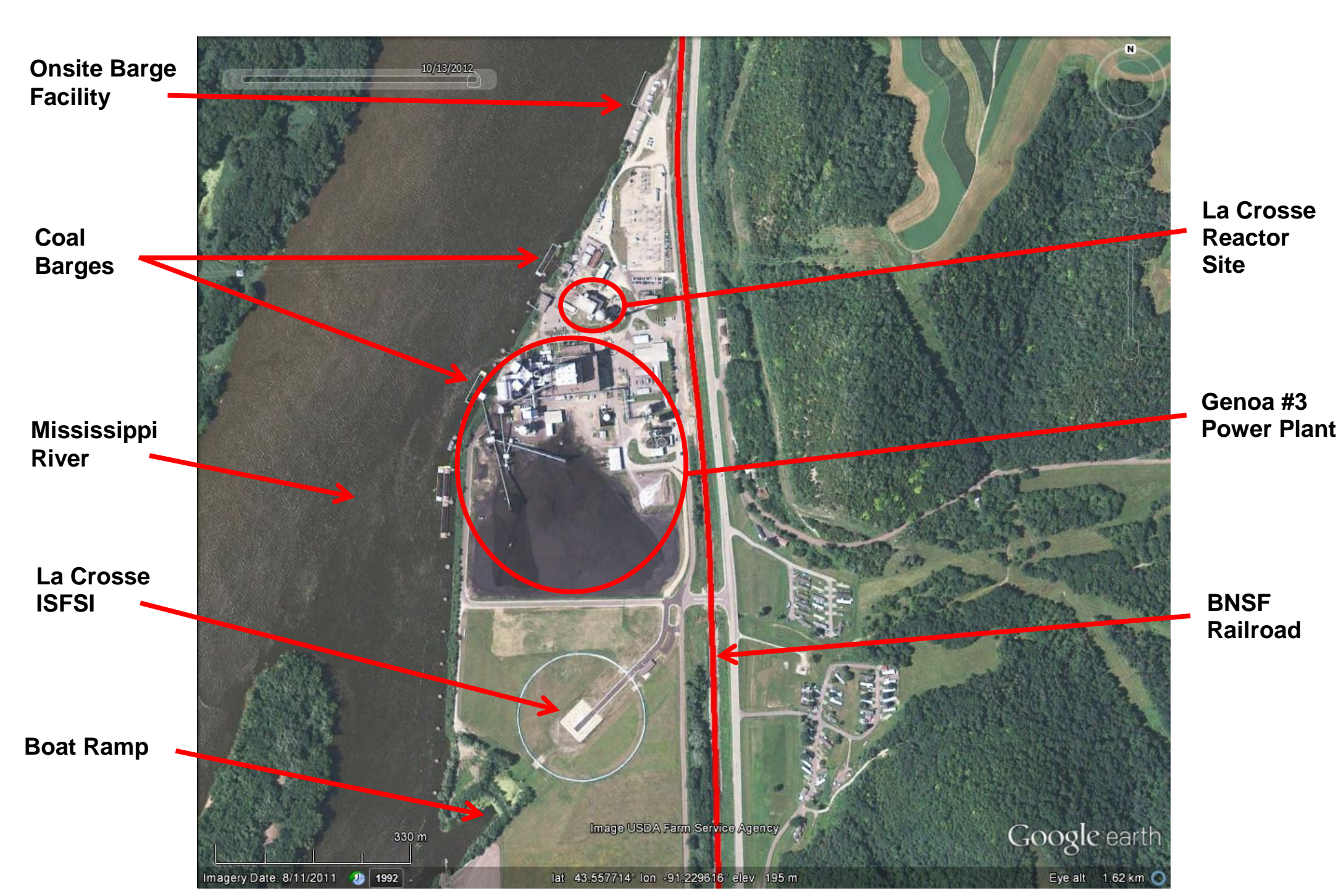

Figure 3-12. Aerial View of La Crosse Site (Google 2012) 


\subsection{Zion}

Figure 3-13 provides an aerial view of the Zion site, which is being decommissioned. The used nuclear fuel has not been transferred from the spent nuclear fuel pool to dry storage at an ISFSI. This transfer is expected to occur in 2013. Figure 3-14 is a drawing of the future Zion ISFSI.

The Zion barge facility used during plant construction was abandoned and the land upon which it was located was donated to the Illinois Beach State Park (TOPO 1994b). Direct rail service to the Zion site is provided by the Union Pacific Railroad. The Union Pacific rail line is designated as track class 4 . Rail service to the Zion site is being reestablished and low-level radioactive waste rail shipments from the Zion site to Clive, Utah are expected to begin in November or December 2012 (ZionSolutions 2012). 


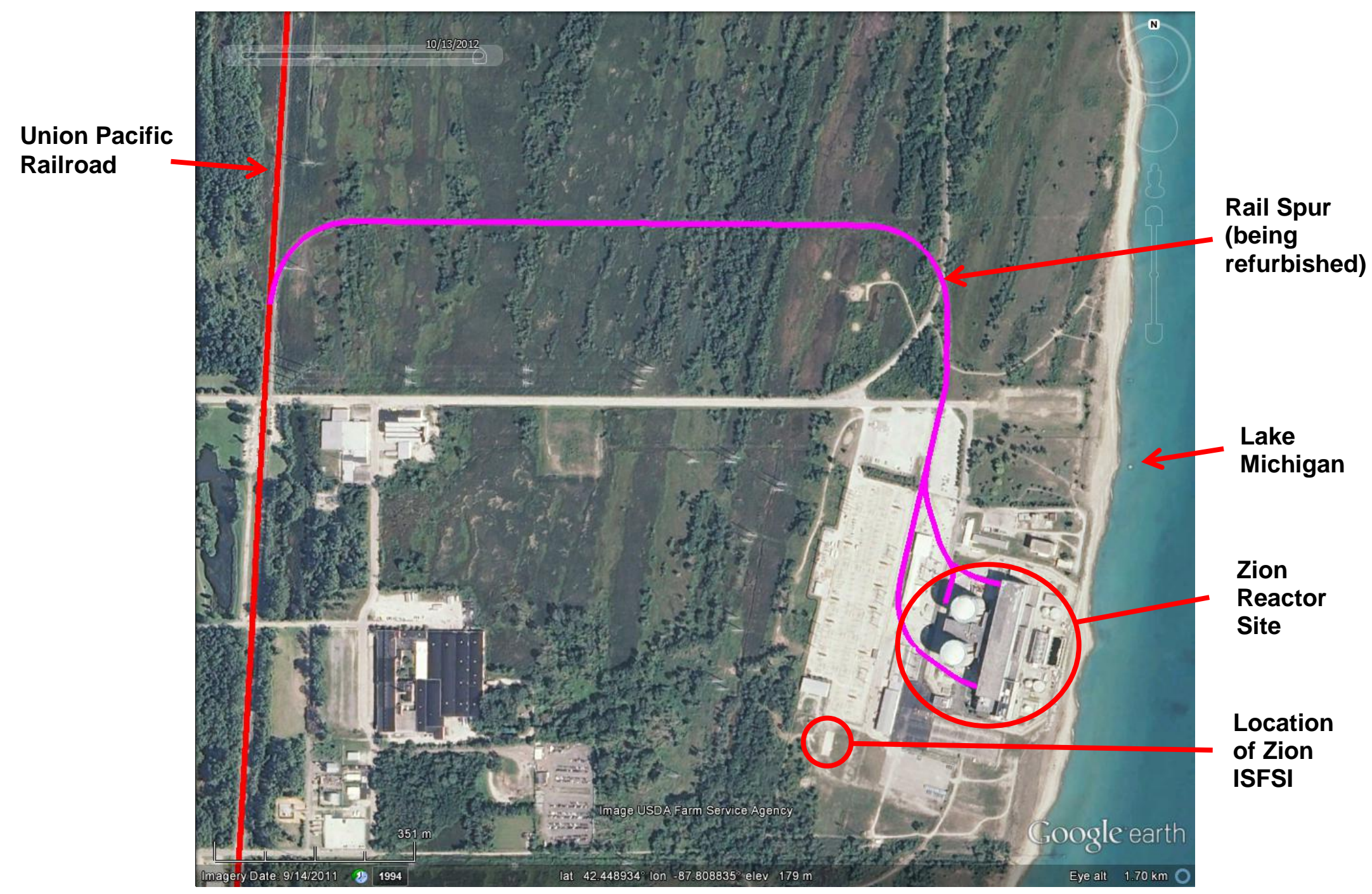

Figure 3-13. Aerial View of Zion Site (Google 2012)

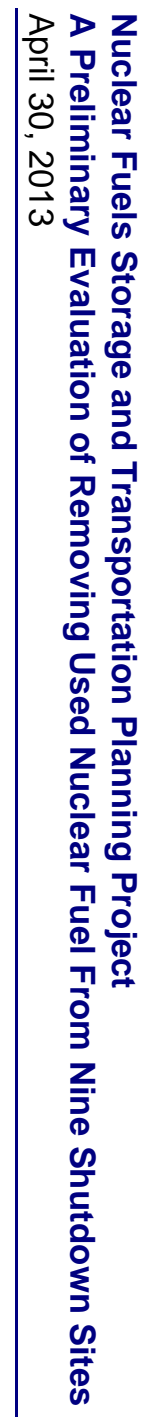




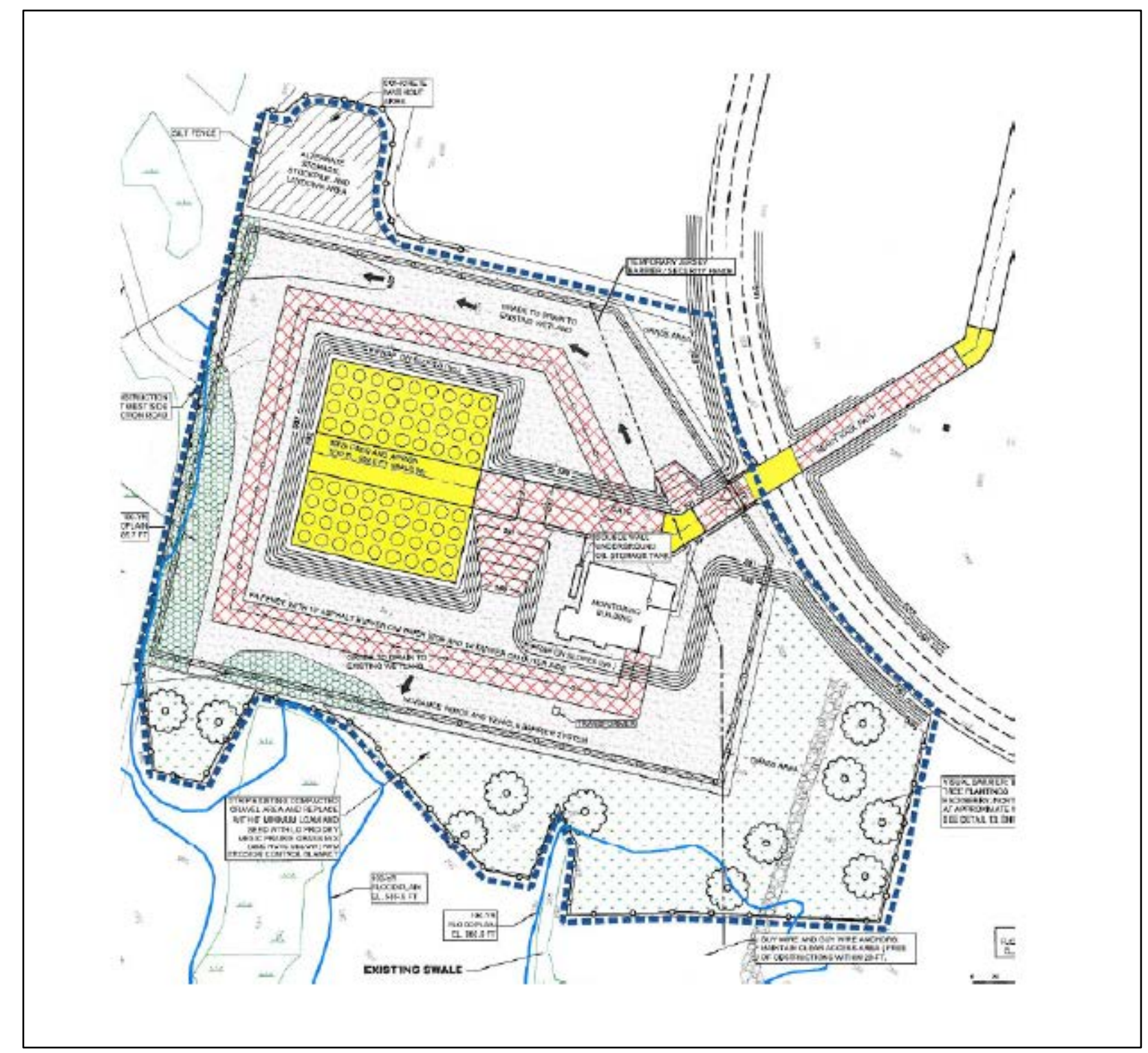

Figure 3-14. Drawing of the Future Zion ISFSI (ZionSolutions 2012) 


\section{NEAR-SITE TRANSPORTATION INFRASTRUCTURE AND EXPERIENCE}

This section presents current information and assessments regarding the requirements for and capabilities of transportation infrastructure in the vicinity of the nine shutdown sites to accommodate shipments of rail/intermodal transportation casks containing the sites' used nuclear fuel. The characteristics of onsite transportation infrastructure at the shutdown sites and the interfaces where onsite and offsite transportation infrastructure connect are discussed in Section 3.

\subsection{Overview of Requirements for Offsite Transportation Infrastructure}

Offsite transportation of rail/intermodal casks containing used nuclear fuel will require that the offsite rail network, roads, or navigable waters (herein referred to as transportation infrastructure) in the vicinity of each of the shutdown sites be capable of accommodating the size and weight of the rail/intermodal casks containing used nuclear fuel and of the transport vehicles that will be used to move the casks. It will also be necessary for the operational capacities (e.g., traffic flow or re-routing capacity) of the offsite infrastructure to be capable of accommodating the movement of casks on transporters.

\subsubsection{Railroad Requirements}

Offsite railroads, either Class I (mainline railroads), II (typically regional railroads), or III (typically shortline railroads) railroads, ${ }^{10}$ might be used to transport casks at sites that have either direct rail access (Maine Yankee, Rancho Seco, Trojan, La Crosse, and Zion sites) or near-site rail access with an acceptable branch line or rail siding where casks would be transferred to rail cars from heavy haul trucks or barges (Yankee Rowe, Connecticut Yankee, Humboldt Bay, and Big Rock Point sites).

Rail infrastructure components including roadbed, track geometry and track structure to meet Class 2 Track Safety Standards, and over- and under-grade bridges, must be sufficient to ensure that these features of a railroad are capable of supporting a 6-, 8-, or 12-axle cask-railcar that conforms to Association of American Railroads (AAR) Standard S-2043 (AAR 2008) and has a gross loaded weight up to 500,000 lb. The railroad's infrastructure must comply with the regulatory standards of the Federal Railroad Administration and also have the capability to accommodate a train consisting of up to five cask-railcars, two or more buffer cars containing ballast, two locomotives, and an escort car.

\footnotetext{
${ }^{10}$ Railroads are classified by the Surface Transportation Board based on their annual operating revenues. The class to which a carrier belongs is determined by comparing its adjusted operating revenues for three consecutive years to the following scale: Class I - \$250 million or more, Class II - \$20 million or more, and Class III - \$0 to \$20 million. The following formula is used to adjust a railroad's operating revenues to eliminate the effects of inflation: Current Year's Revenues $\times$ (1991 Average Index $\div$ Current Year's Average Index). The average index (deflator factor) is based on the annual average Railroad Freight Price Index for all commodities (STB 2012).
} 
The height and width clearances of the track alignment also must be sufficient to accommodate a loaded cask-railcar having an overall height up to 15 feet and a width up to 12 feet. Clearance along track curves must be sufficient to accommodate a railcar having a length up to 100 feet and a width of up to 12 feet. The radius of track curves (including curves in switching yards that may be used) must be sufficient to accommodate a 6-, 8-, or 12- axle railcar with a distance between the front and rear truck bolsters up to 80 feet.

For sidings or railheads where casks would be transferred from heavy haul trucks or barges to railcars, the length of rail should accommodate a minimum of one cask-railcar having a length up to 100 feet and a width up to 12 feet. The curvature of the turnout for the siding should allow for a 6-, 8-, or 12-axle cask-railcar with spacing between the front and rear truck bolsters up to 80 feet. Sidings where intermodal transfers will be conducted should include a cleared and level adjacent operations area that can support heavy vehicles and equipment and that is no less than 200 feet long and 50 feet wide. For sidings where only one- or two-cask railcars can be accommodated, there should be a nearby rail siding or rail yard where the train can be assembled.

For some sites it may be necessary to conduct intermodal operations at a nearby rail siding that has limited operating space and is close to a railroad's operating track. For such sidings it may not be possible to conduct concurrent railroad train operations on the main rail line while intermodal transfer and switching operations necessary for cask shipments are being conducted. To use such sidings, it will be necessary for the railroad to have a flexible operations schedule for, or alternative routing around, the affected track.

\subsubsection{Highway Requirements}

All nine shutdown sites have onsite roads that connect to local roads or highways. Four of these sites (Yankee Rowe, Connecticut Yankee, Humboldt Bay, and Big Rock Point sites) do not have direct access to a railroad. The standards used for the design, construction, and maintenance of local roads and highways depend on several factors, including whether the road or highway is designated as an interstate highway, U.S. highway, state highway, or local road.

Interstate and U.S. highway standards are established by the Federal Highway Administration. These standards establish the mechanical requirements for lane width, road shoulder, overhead clearance, grade, curvature, road-bed, bridges and culverts, and primary pavement materials and thickness for all roads designated as Interstates and U.S. Highways. The standards are the basis for federal weight and size limits for trucks and buses. States are authorized to issue special permits for vehicles that exceed these limits for weight and size for trucks and buses. The special permits that states issue typically consider the route to be used, normal traffic on the route, time of day and duration of use, total weight of the permitted vehicle, wheel loads, distribution of the total weight of a vehicle over multiple wheels, axle spacing, and the frequency of overweight and oversize vehicles using the permitted roadways. The permits also consider the condition of designated highways and the load capacities of the highway's bridges, overpasses, and culverts. 
Standards for state highways are typically less prescriptive than standards for federal highways. Many state highways are narrower and have steeper grades and sharper curves than do federal highways and often have narrow shoulders and less overhead clearance. In addition, many state highways do not have the substantial roadbed and pavement federal highways do. State highway bridges and culverts also typically have less load capacity than do bridges and culverts for federal highways. State highway departments issue permits for overweight and oversize vehicles that use the state highways. State permitting processes for overweight and oversize vehicles that travel on state highways are generally the same as those for oversize and overweight vehicles that travel on federally designated highways.

For local roads, standards adopted by local governments consider anticipated traffic densities, truck traffic use, climate, terrain, and geology. Local roads may be wide or narrow, often have short-radius curves and sharp corners, may have substantial sub-base and pavements or may be only intended for light vehicle use, and often have low overhead clearances because of utility lines or limited overpass grade separations. Weight limits for bridges and culverts for local roads are typically less than for the same kinds of structures on state or federal highways. In addition, local roads pass through residential and local business communities often with businesses and residences being located close to the right-of-way. These local roads provide commuter, employee, and pickup and delivery vehicles access to retail and other businesses, and provide connectors to state and federal highways.

Although the shutdown sites are generally located in rural areas, all are served by local roads that, if applicable and if practical, would be used by heavy haul vehicles. Local authorities would issue permits for overweight and/or oversize vehicles to travel on non-state, non-federal, local roads. Such permits may be issued following consultation with local elected officials and thus may consider factors (e.g., desirability of removal of overhanging tree branches) that are in addition to technical factors concerning the proposed vehicle, load, route, and conditions of roads and road structures, and time of day for operations.

It is likely that the travel speeds of the vehicles from the shutdown site to a nearby railhead or siding would be limited to an average of less than 5 miles per hour. This slow pace, based on experience, is because the local roads that would be used typically have limited capacity to accommodate oversize and overweight vehicles that would transport rail/intermodal casks from a shutdown site to a nearby railhead. Owners of sites such as Yankee Rowe and Connecticut Yankee, who have contracted for the use of heavy haul vehicles to move heavy equipment from their sites to railheads, report that travel times can be expected to be 8 hours or more even for distances of less than 10 miles. In addition, the heavy haul vehicle would likely block the flow of traffic on most local roads because of its size and because the roads often have two, narrow (10or 12-feet) lanes and limited shoulders. Thus, one or more alternate routes must be available for use by local traffic at times when the heavy haul vehicle is on the road.

Additional requirements for roads that would be used by heavy haul trucks include the following:

- Overhead clearances must be (or be moveable or clearable to) 15 feet or greater above the roadway. 
- The side-to-side width of the narrowest section of a road should be sufficient to allow passage of a 14-foot-wide vehicle.

- Curves and corners must have sufficient inside clearances to allow a 100-foot-long center section of a heavy haul vehicle to negotiate the turns without interference (the greatest requirement is for a clearance of 34 feet on the inside of a $90^{\circ}$ corner for a 20 -foot-wide road).

- Bridges, bridge supports, dam crossings, and culverts must be capable of supporting the distributed load of the heavy haul vehicle (approximately 4,000 lb. [2 tons] per lineal foot of roadway) or must have spans that are short enough to allow use of jumper bridge-deck reinforcements.

- Road sub-grade and pavement must be firm and stable and be capable of supporting the distributed load of the heavy haul vehicle (approximately 4,000 lb. [2 tons] per lineal foot of roadway over a length of 100 feet). Weak areas of roadway may be temporarily improved by use of top-ballast or jumper reinforcements.

\subsubsection{Navigable Waterway Requirements}

Offsite navigable waterways that might be used by barge operators to transport rail/intermodal casks could be accessed directly from onsite barge landings at the Maine Yankee, Trojan, and La Crosse sites; from onsite canals that connect from onsite landings to a waterway at the Connecticut Yankee site; or from offsite landings where rail/intermodal casks would arrive on heavy haul trucks and be off-loaded onto barges at the Humboldt Bay site. Barge landings may be docks or unimproved shorelines. Barges might be loaded at shorelines along navigable waterways. The Humboldt Bay and Big Rock Point sites have unimproved shorelines that might be used to land barges.

Requirements for using navigable waterways to ship rail/intermodal casks containing used nuclear fuel include the following:

- The waterway is an inland or inter-coastal navigable waterway used by commercial maritime traffic and is maintained by the U.S. Army Corps of Engineers, port authorities, or other federal authorities (e.g., Tennessee Valley Authority).

- Docks or shoreline landings for barges must have securing stanchions or other securing points adequate for securing a barge (sea-going, lake, or river barge, depending on the route) having a minimum cargo capacity of 2,000 deadweight tons.

- Navigation from a dock or shoreline landing (where rail/intermodal casks would be onand off-loaded to and from barges) to the navigable section of the waterway is direct and can be determined by inspection of maritime charts to be safe and clear of marine hazards. 


\subsection{Offsite Transportation Experience, Infrastructure, and Scenarios for Shutdown Sites}

It is generally accepted that railroads would be the principal mode of long-distance transportation of rail/intermodal casks, both unloaded and containing used nuclear fuel. However, because four of the nine shutdown sites (Yankee Rowe, Connecticut Yankee, Humboldt Bay, and Big Rock Point sites) do not have direct access to a Class I, II, or III railroad, an alternative mode of transportation would be needed to move loaded and unloaded casks, and other heavy or large equipment that would be used, between the sites and a nearby railroad sidings or railheads. Even though a site has direct access to a railroad, conditions on or along the connecting rail line may not permit the line to accommodate railcars that are 100 feet long, 12 feet wide, 250 gross ton, and have 6-, 8- or 12-axles. The following sections describe each of the modal scenarios that may apply for offsite transportation of loaded and unloaded rail/intermodal casks for the nine shutdown sites. Included are descriptions of the near-to-the site transportation infrastructure and relevant experience in making shipments of large, heavy, radioactive components from the sites.

\subsubsection{Direct Rail Transport from Shutdown Sites}

For direct rail transport, shutdown sites that have direct access to a Class I, II, or III railroad that can accommodate the weight and size of the loaded cask railcars and meet the Federal Railroad Administration's regulatory standards via an onsite rail spur, would conduct onsite operations to accept unloaded rail/intermodal casks, load the casks, prepare the casks for shipment, and load them back onto rail cars on the site. The Maine Yankee, Trojan, Rancho Seco, La Crosse, and Zion sites are expected to make shipments directly by rail (see Figures 4-1 through 4-5). All of these sites have or could reestablish long onsite rail spurs that should be able to accommodate trains having eight or more railcars (two buffer cars, a security escort car, and five or more cask cars). 


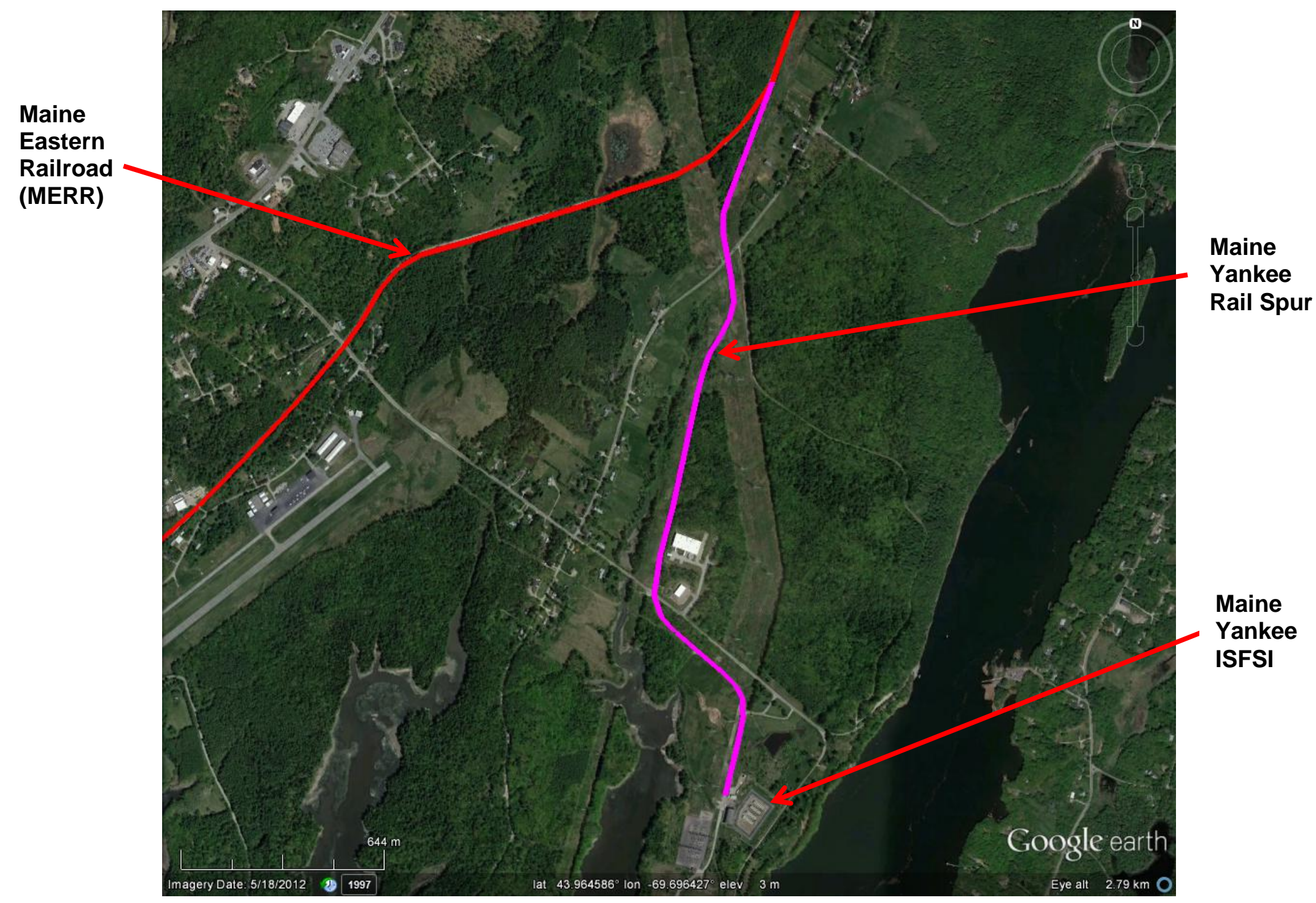

Figure 4-1. Rail Interface at Maine Yankee (Google 2012)

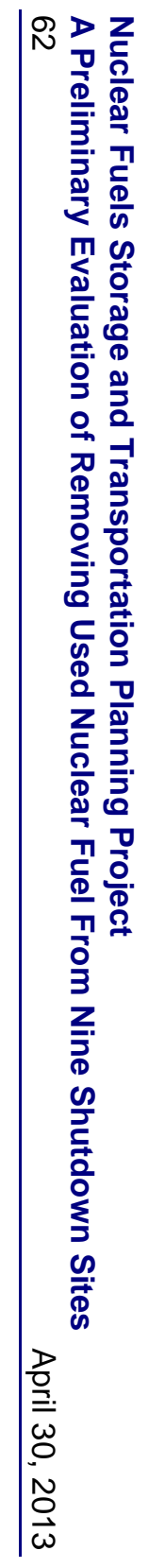




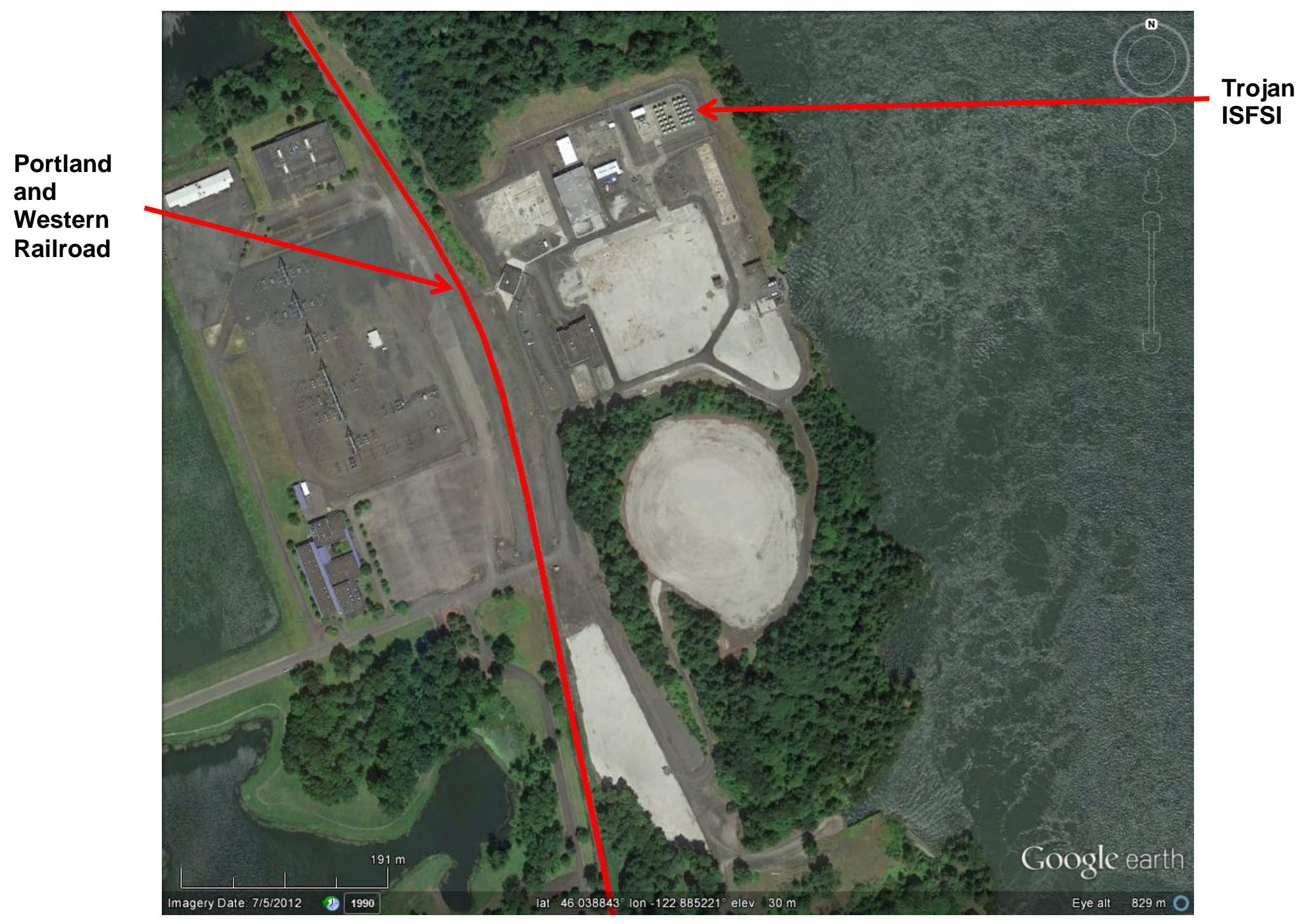

Figure 4-2. Rail Interface at Trojan (Google 2012) 


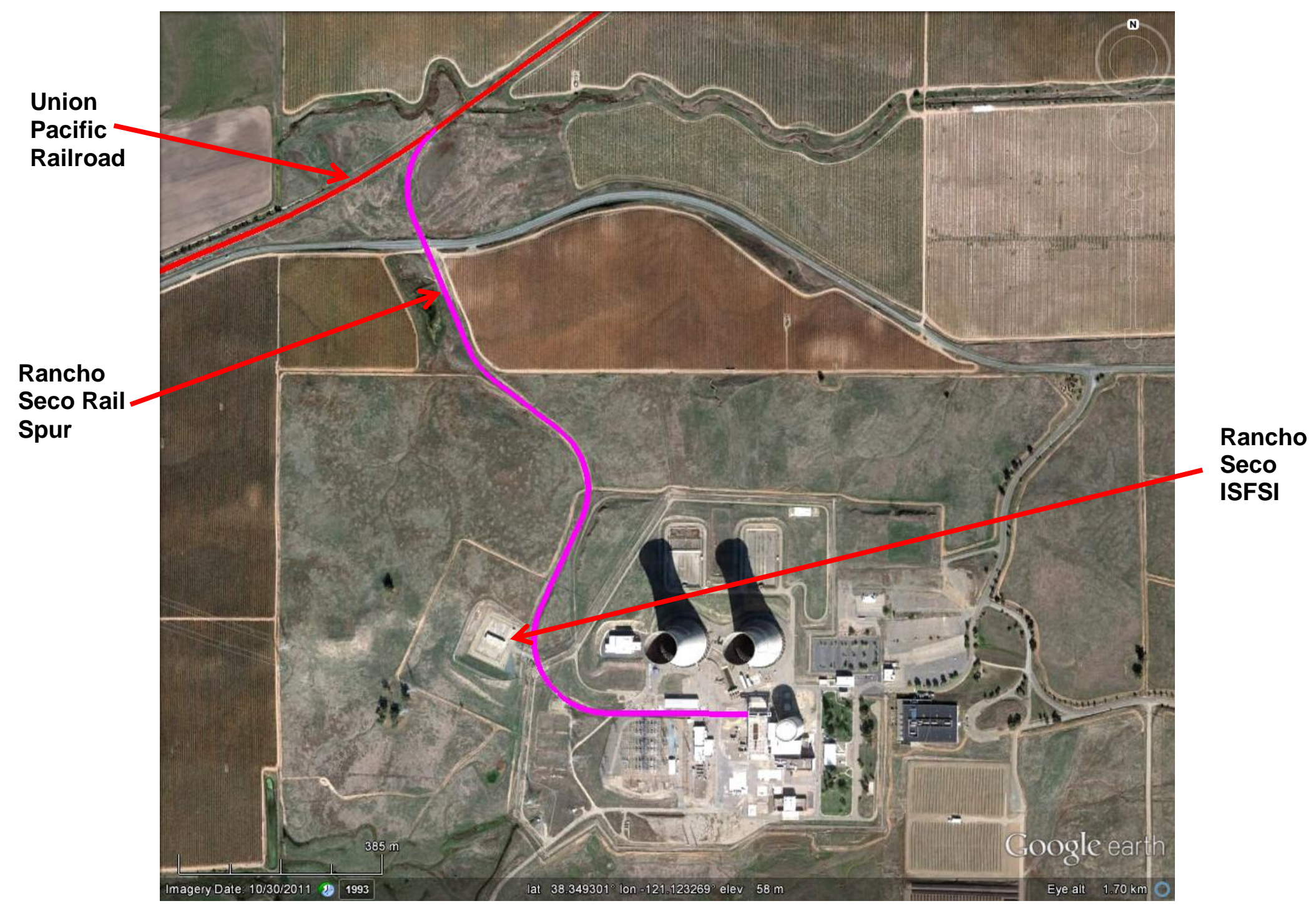

Figure 4-3. Rail Interface at Rancho Seco (Google 2012)

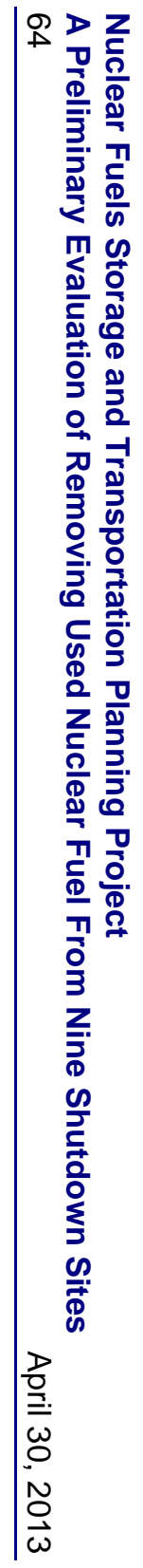




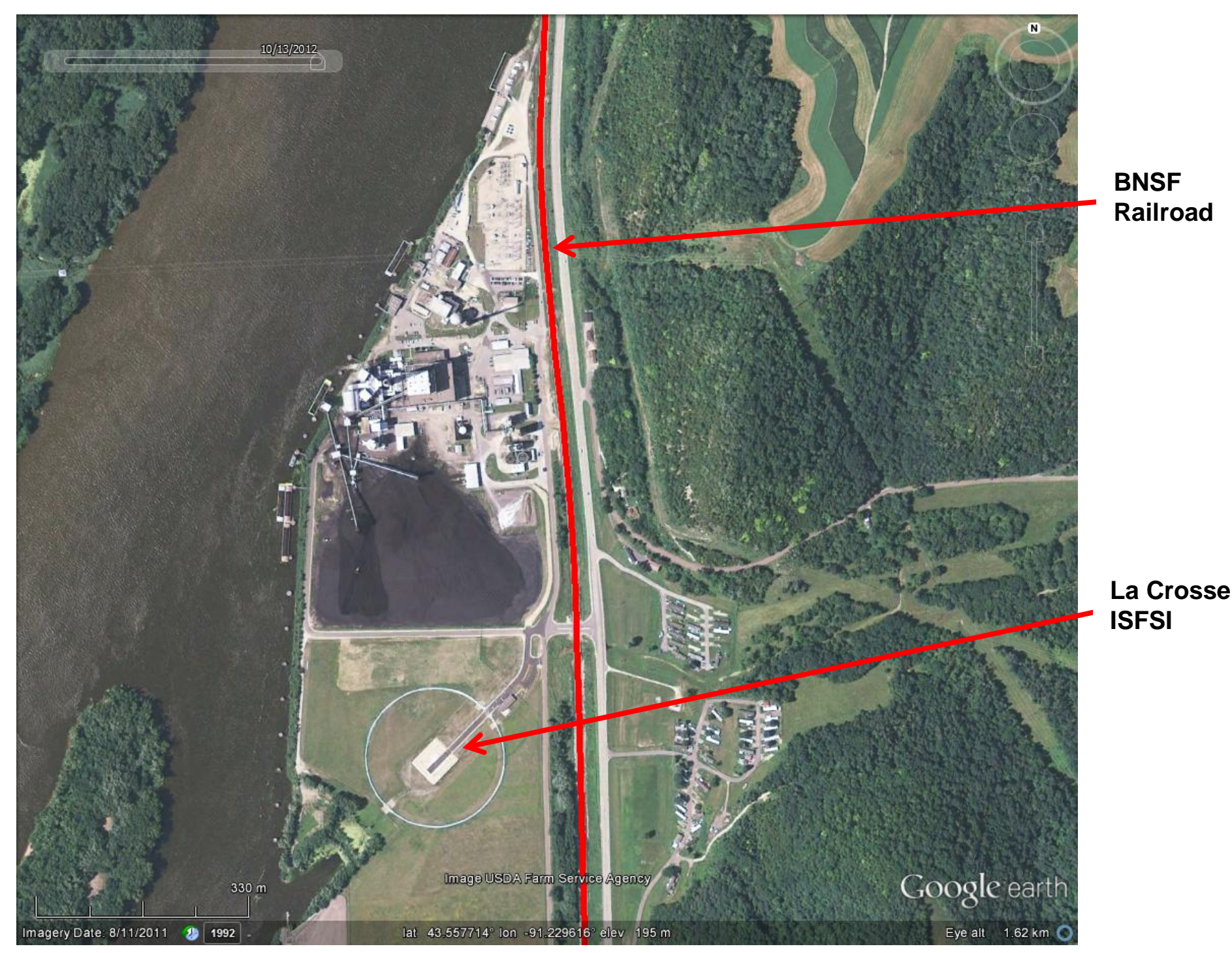

Figure 4-4. Rail Interface at La Crosse (Google 2012) 


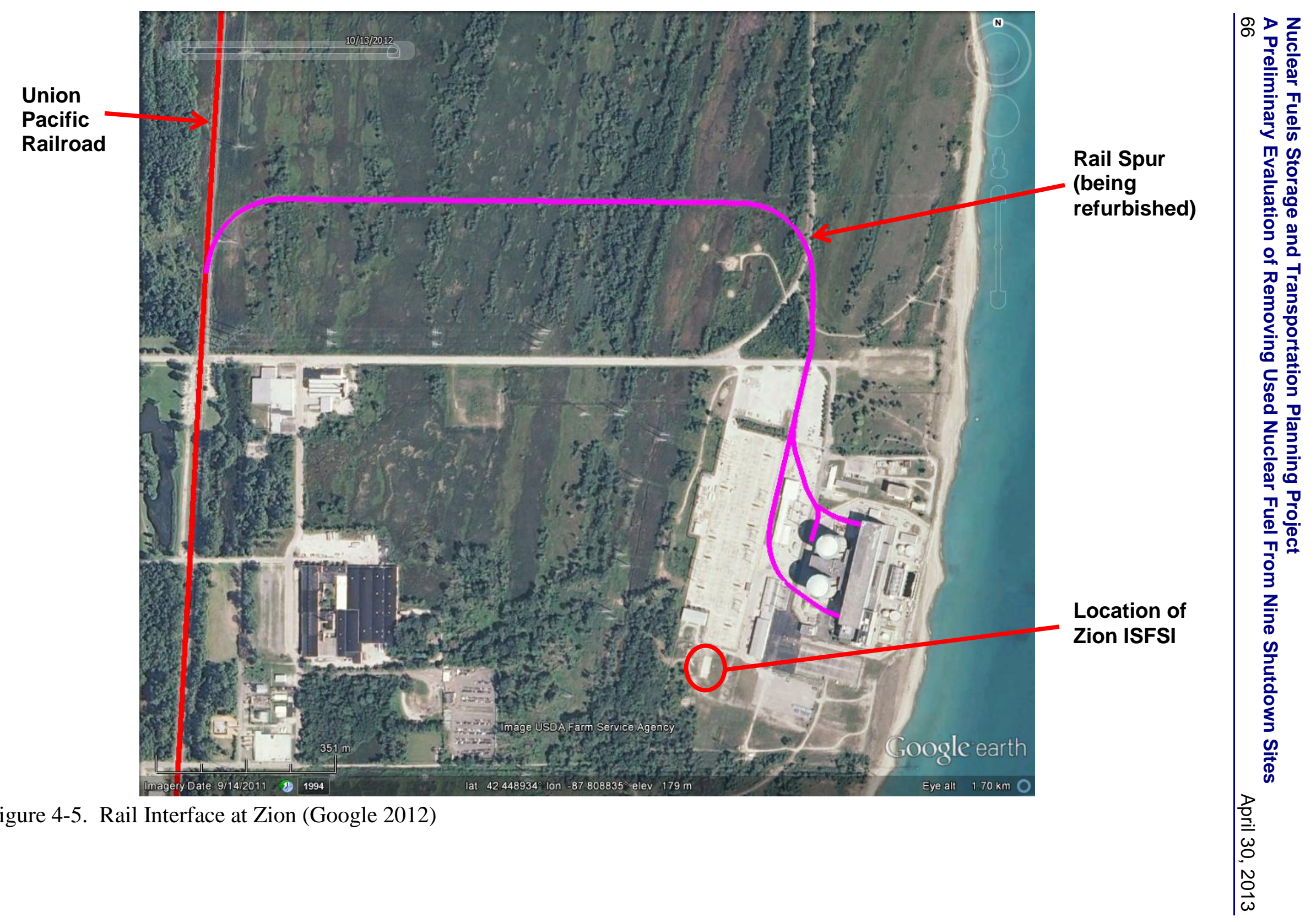




\subsubsection{Heavy Haul Truck from Shutdown Sites to Railhead}

The Yankee Rowe, Connecticut Yankee, Humboldt Bay, and Big Rock Point sites do not have onsite rail spurs or railroads that pass near to the sites or along the site boundaries. For these sites, heavy haul trucks could be used to move transportation casks over public highways to a railhead or rail spur that provides access to a railroad that meets Federal Railroad Administration's regulatory standards and can accommodate the loaded transportation casks.

For shipments of casks containing used nuclear fuel that require the use of heavy haul trucks, the casks would be prepared for shipment at the ISFSI site and loaded onto a transport cradle that would be loaded onto the transport trailer of a heavy haul truck. The truck, led and followed by technical and security escorts, would move over an approved, designated highway route to a nearby rail siding or railhead. Heavy lift equipment would be used to transfer the cask and its cradle as a unit from the truck to a railcar at the rail siding or railhead.

In recent years, heavy haul trucks have been used to move large, heavy reactor components from the Yankee Rowe (reactor pressure vessel and steam generators), Connecticut Yankee (pressurizer and steam domes), Big Rock Point (reactor vessel and steam drum), and Zion sites (reactor head). For example in 2000, Transnuclear, Inc. contracted with a heavy haul truck operator to ship the 100-ton (empty and without impact limiters) MP187 transportation cask from the eastern United States to the Rancho Seco site in northern California (see Figure 4-6). Heavy haul trucks were also used to ship the HI-STAR HB storage and transportation casks to the Humboldt Bay site (see Figure 4-7).

In 1997, the Yankee Rowe reactor pressure vessel was moved 7.5 miles on an improved county road by a heavy haul truck the from the Yankee Rowe site to a rail siding (now removed) at the east portal of the Hoosac Tunnel in western Massachusetts (see Figures 4-8 and 4-9). The siding connected to a rail line that is operated by the Pan Am Southern Railroad, a partnership of the Norfolk Southern Railroad and the Pan Am Railroad Company, a northeastern U.S. regional railroad. Figure 4-10 shows the rail line at the east portal of the Hoosac Tunnel and Figure 4-11 shows the east portal of the Hoosac Tunnel. Figure 4-12 shows the Yankee Rowe reactor pressure vessel on the railcar used to transport it to the Barnwell, South Carolina low-level radioactive waste disposal facility. Figure 4-13 shows the route taken from the Yankee Rowe site to the east portal of the Hoosac Tunnel. 


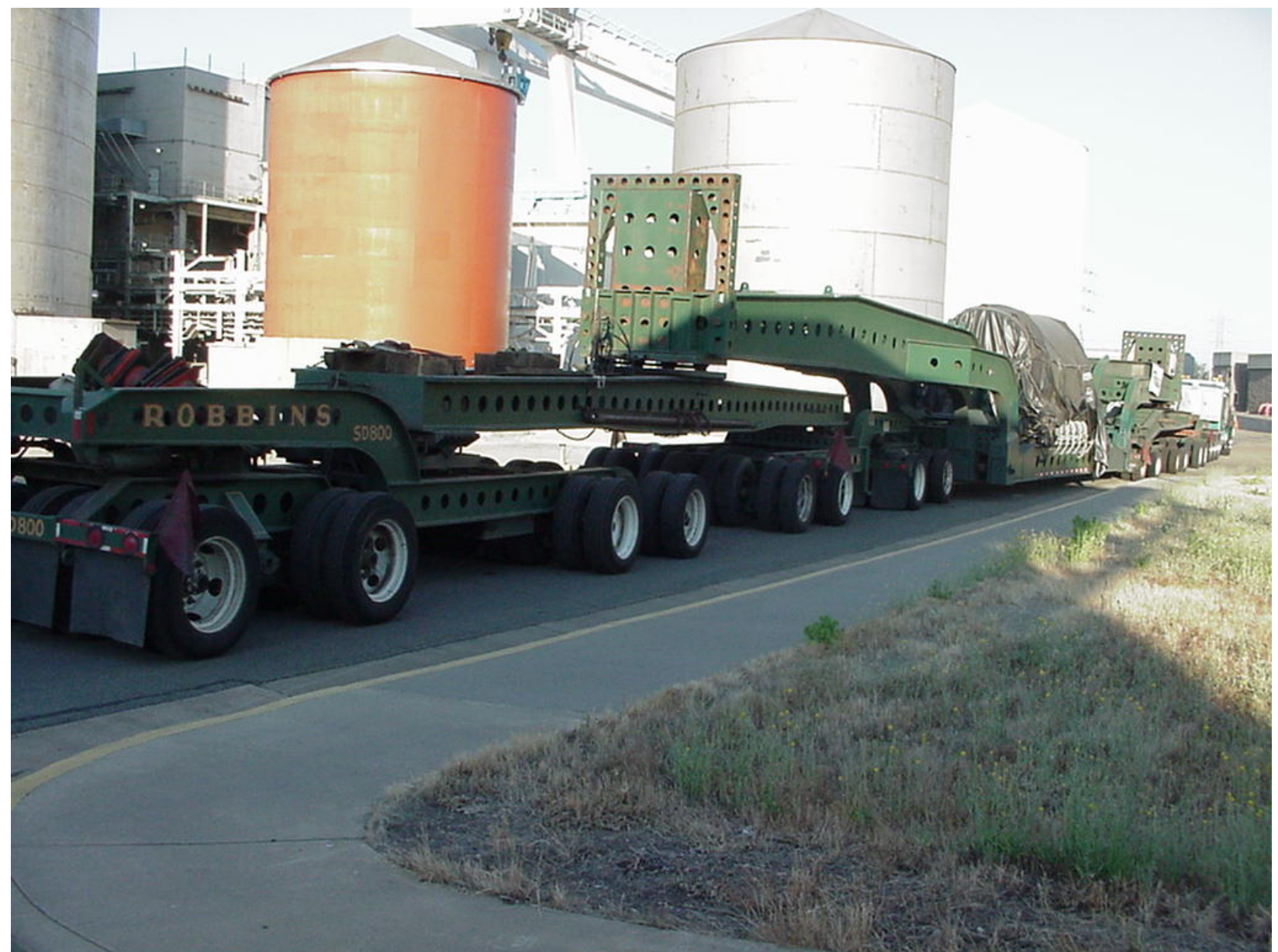

Figure 4-6. MP187 Cask Transported by Heavy Haul Truck 


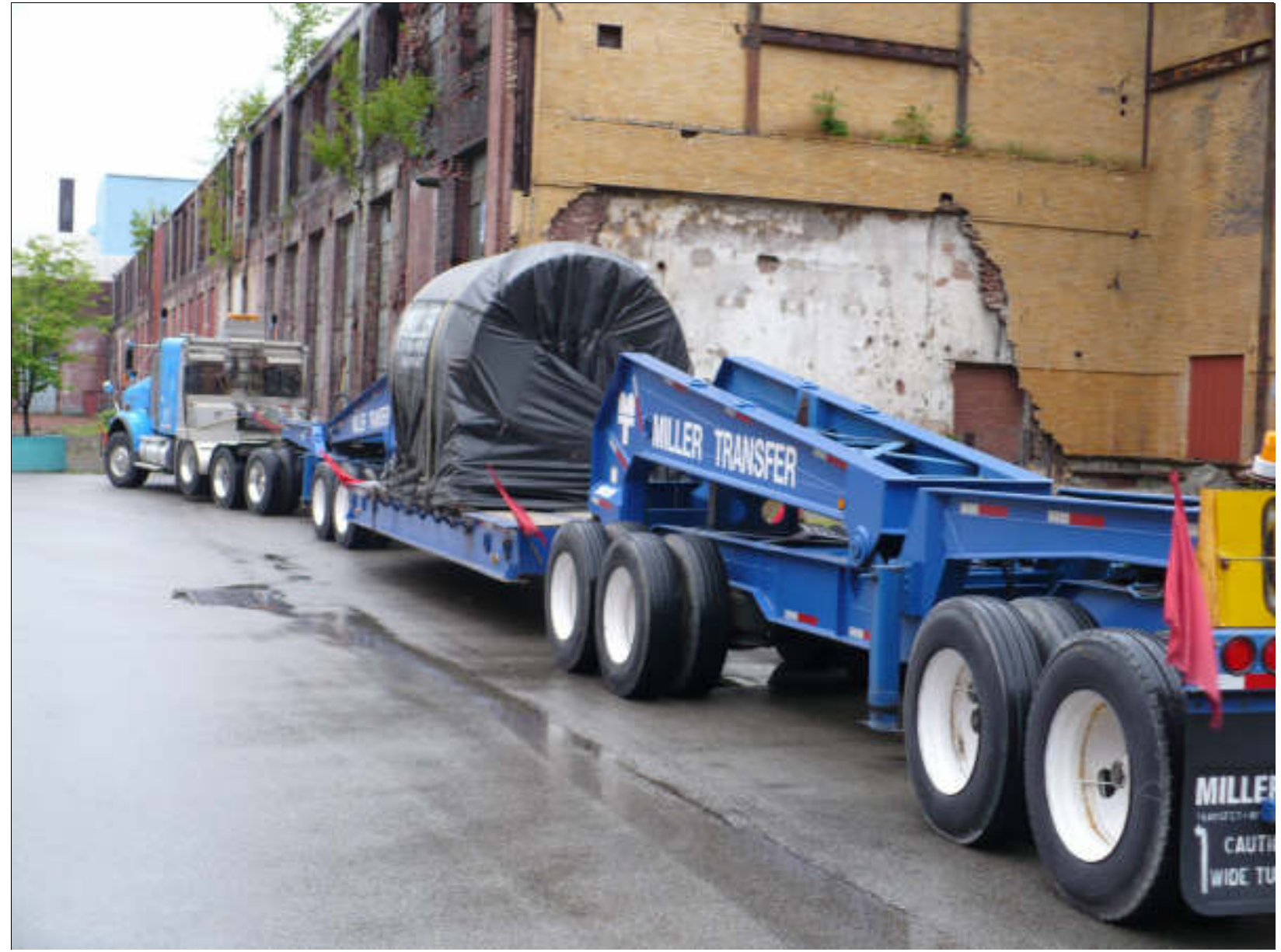

Figure 4-7. HI-STAR HB Cask Transported by Heavy Haul Truck

Photo courtesy of Humboldt Bay

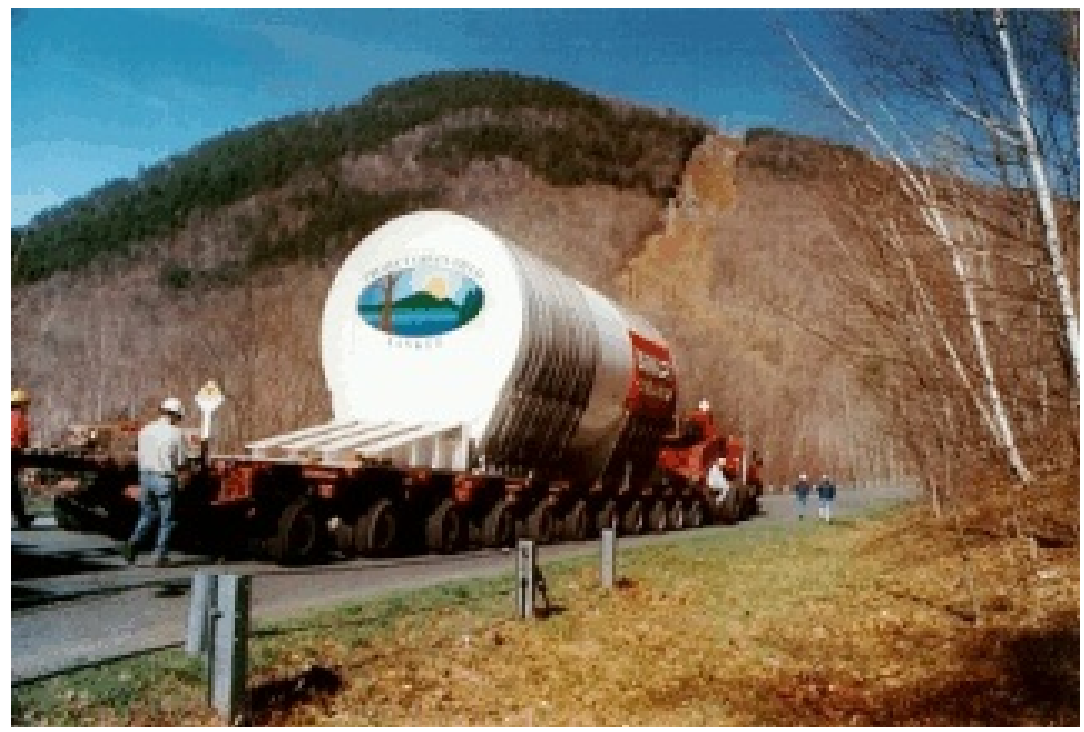

Photo courtesy of Yankee Rowe

Figure 4-8. Yankee Rowe Reactor Pressure Vessel Being Transported by Heavy Haul Truck 


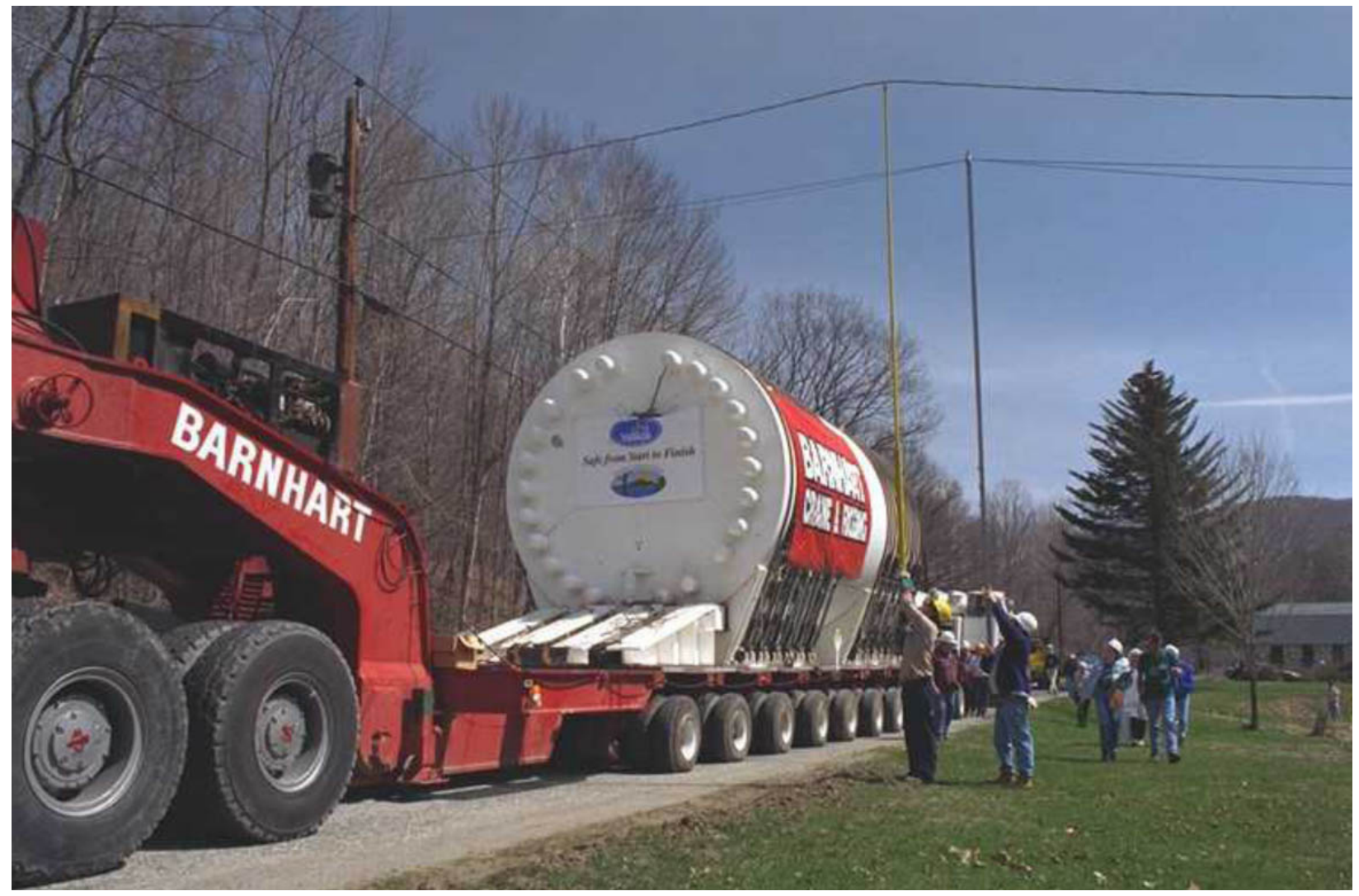

Photo courtesy of Yankee Rowe Figure 4-9. Yankee Rowe Reactor Pressure Vessel on Heavy Haul Truck Moving Under Power Lines 


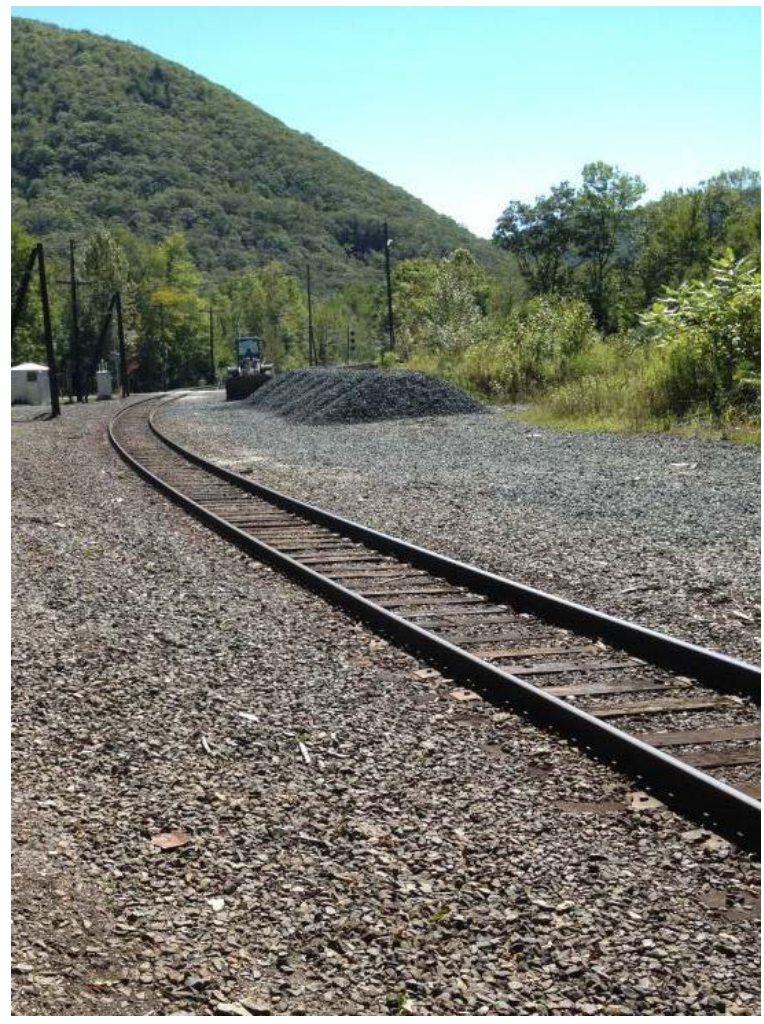

Figure 4-10. Rail Line at East Portal of the Hoosac Tunnel

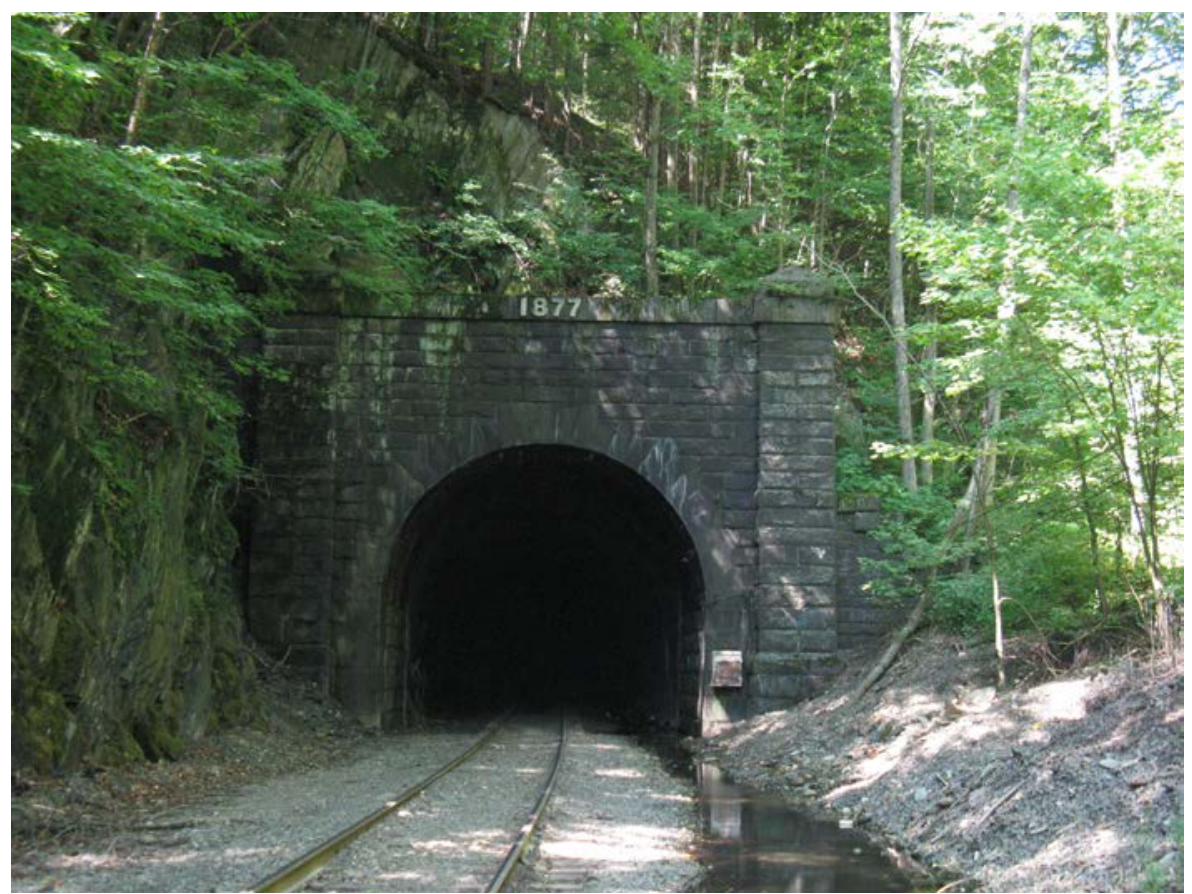

Figure 4-11. East Portal of the Hoosac Tunnel 
Nuclear Fuels Storage and Transportation Planning Project A Preliminary Evaluation of Removing Used Nuclear Fuel From Nine Shutdown Sites

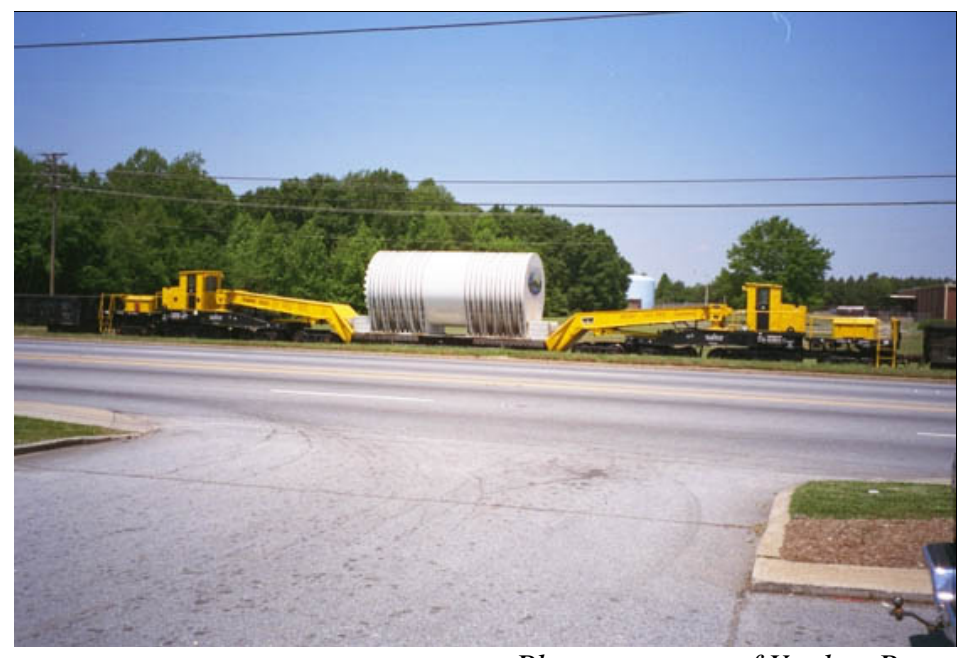

Photo courtesy of Yankee Rowe

Figure 4-12. Yankee Rowe Reactor Pressure Vessel on Railcar 


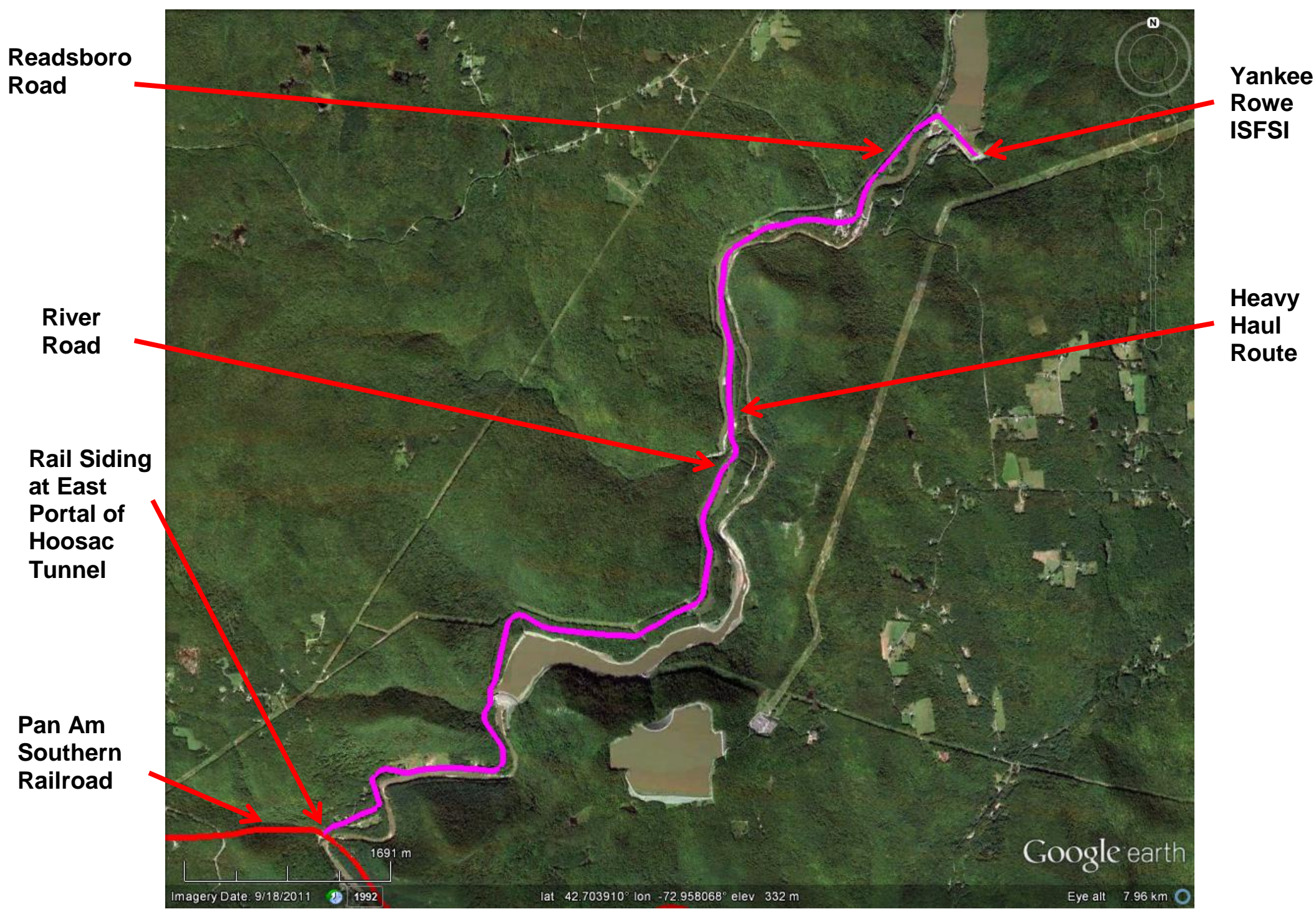

Figure 4-13. Yankee Rowe Reactor Pressure Vessel Heavy Haul Truck Route (Google 2012) 
In 2003, the reactor pressure vessel from the Big Rock Point plant was moved by a heavy haul truck about 52 miles to a rail siding near Gaylord, Michigan and then was transported by rail to the Barnwell, South Carolina low-level radioactive waste disposal facility (Petrosky 2004). The Big Rock Point pressure vessel and its shipping package weighed more than 565,000 lb. (Figures 4-14 and 4-15). Figure 4-16 shows the route taken from the Big Rock Point site to Gaylord, Michigan. The Big Rock Point steam drum was also moved by heavy haul truck about 13 miles to a rail siding near Petoskey, Michigan and then was transported to the Energy Solutions low-level radioactive waste disposal facility in Clive, Utah (Tompkins 2006). The steam drum weighed 200,000 lb. (Figures 4-17 and 4-18). Figure 4-16 shows the route taken from the Big Rock Point site to Petoskey, Michigan.

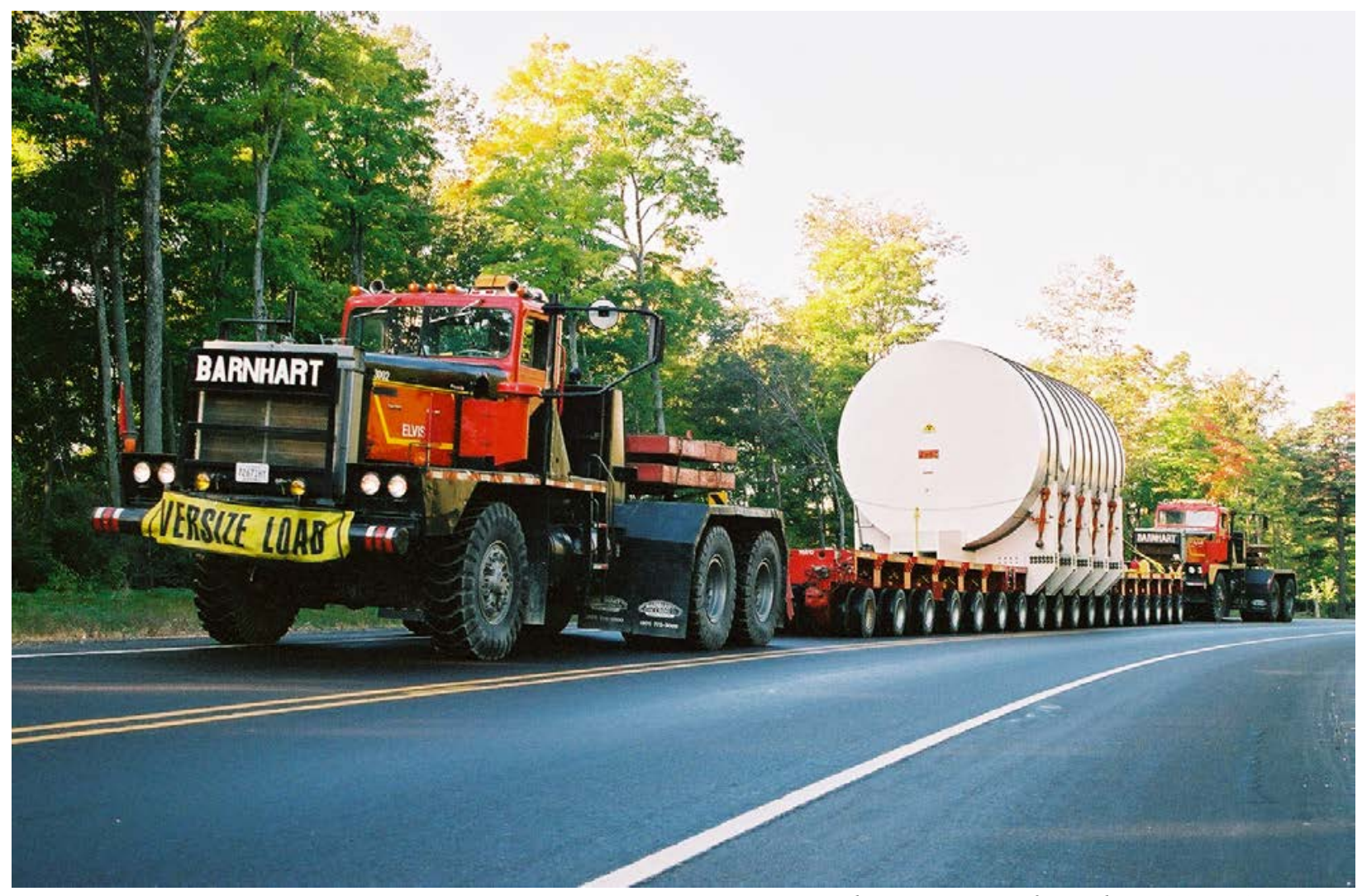

Photo courtesy of Barnhart Crane \& Rigging

Figure 4-14. Big Rock Point Reactor Pressure Vessel on Heavy Haul Truck 


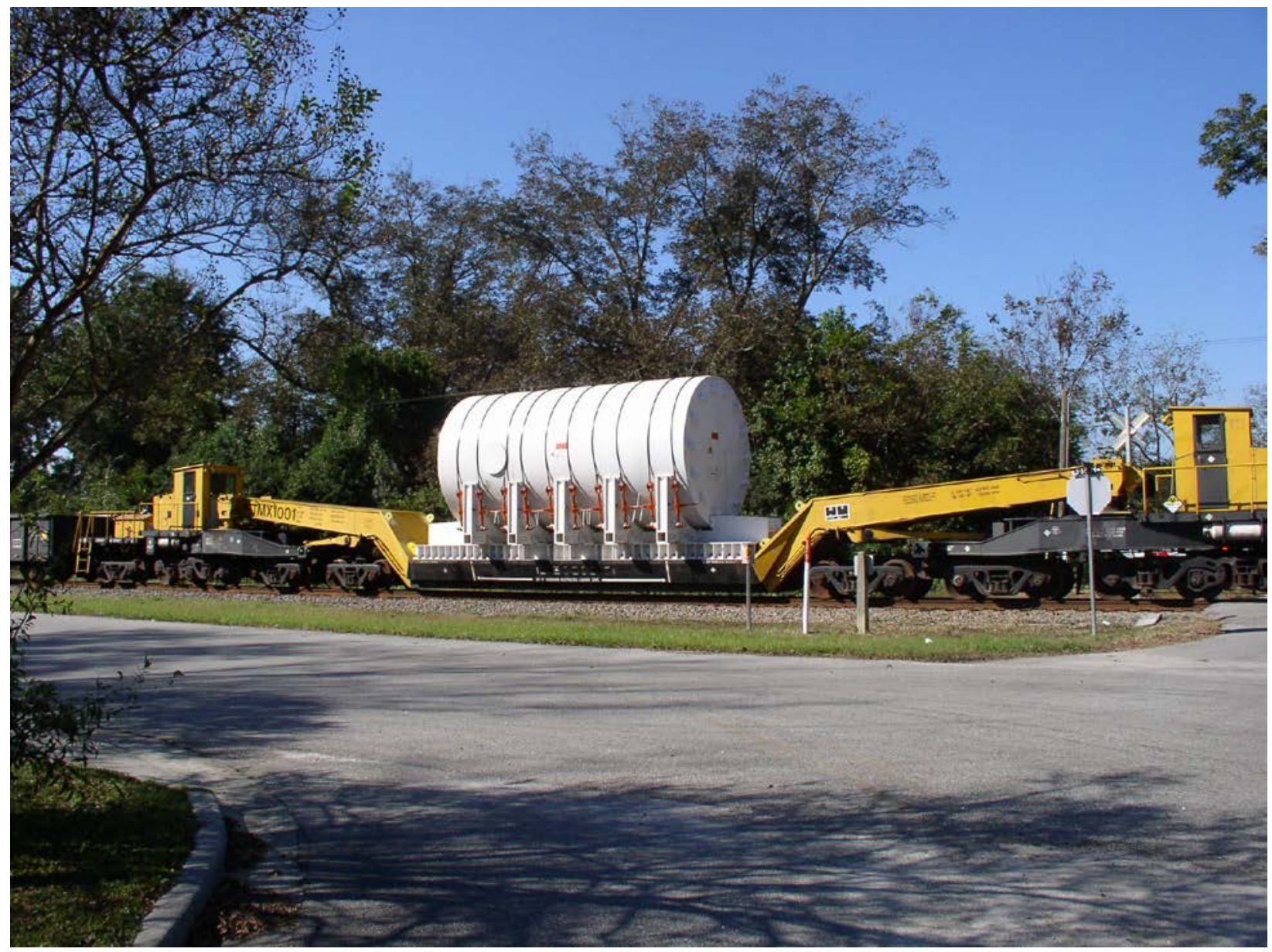

Figure 4-15. Big Rock Point Reactor Pressure Vessel on Railcar 


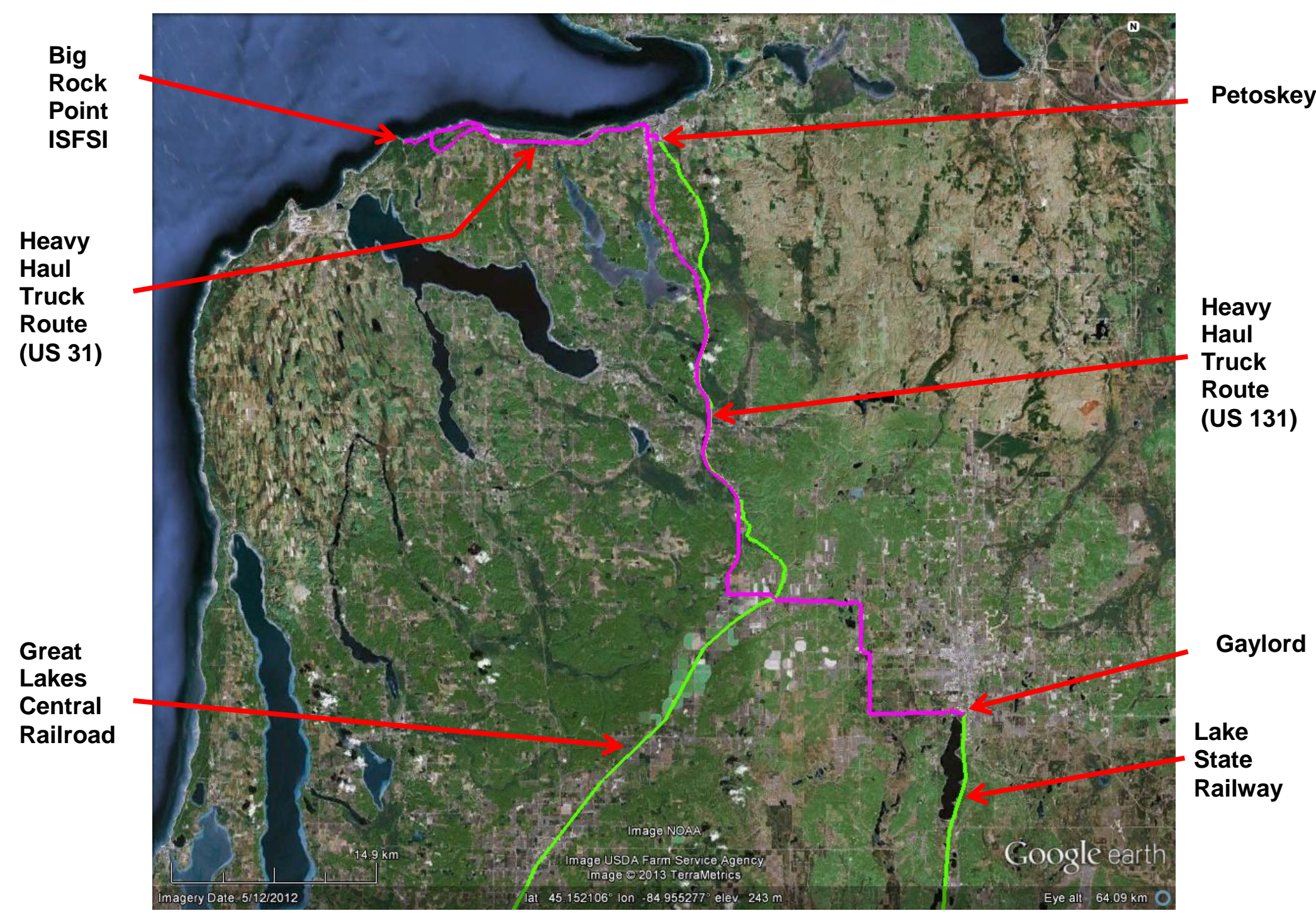

Figure 4-16. Big Rock Point Reactor Pressure Vessel Heavy and Steam Drum Haul Truck Routes (Google 2012) 


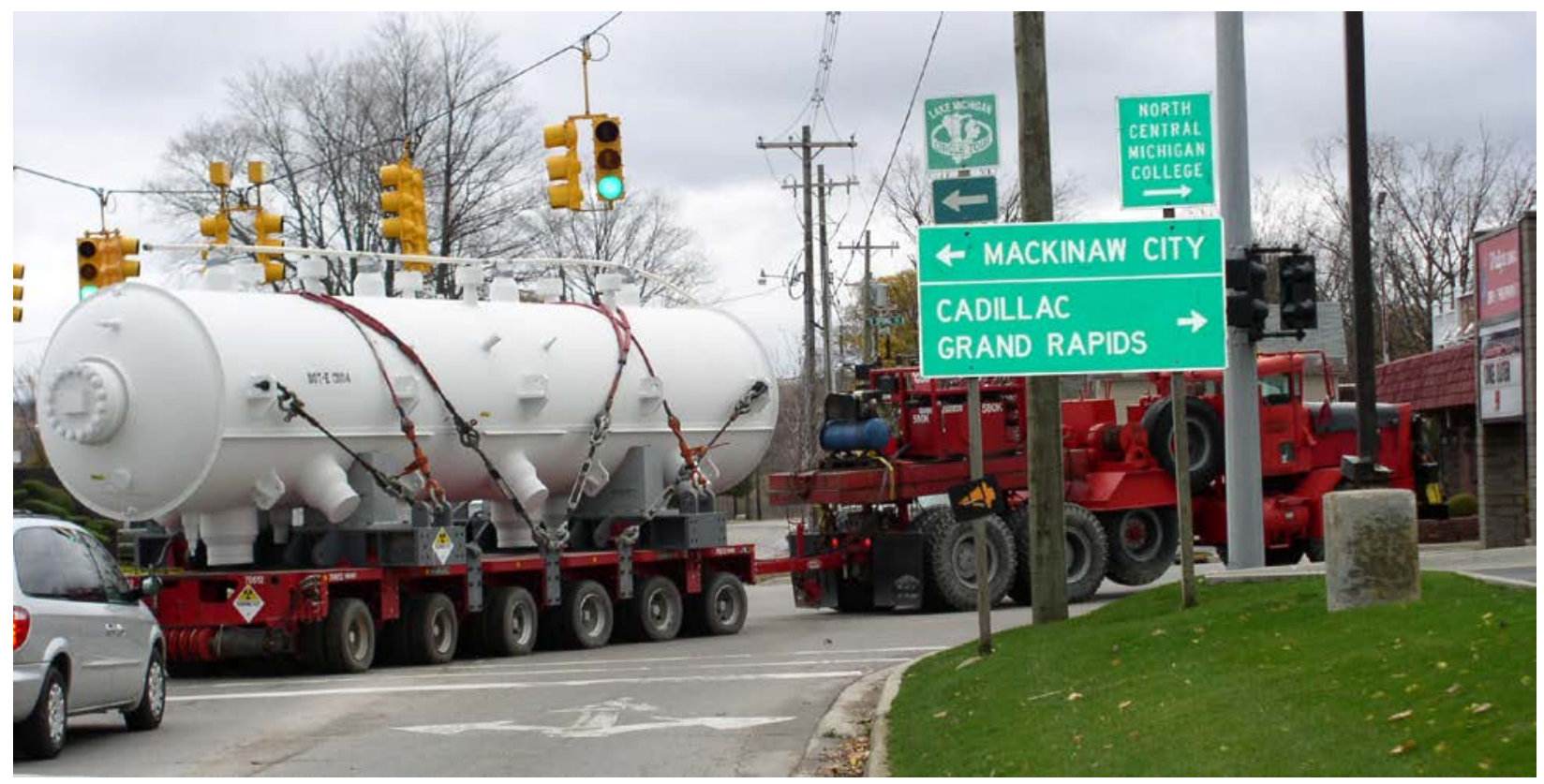

Figure 4-17. Big Rock Point Steam Drum on Heavy Haul Truck

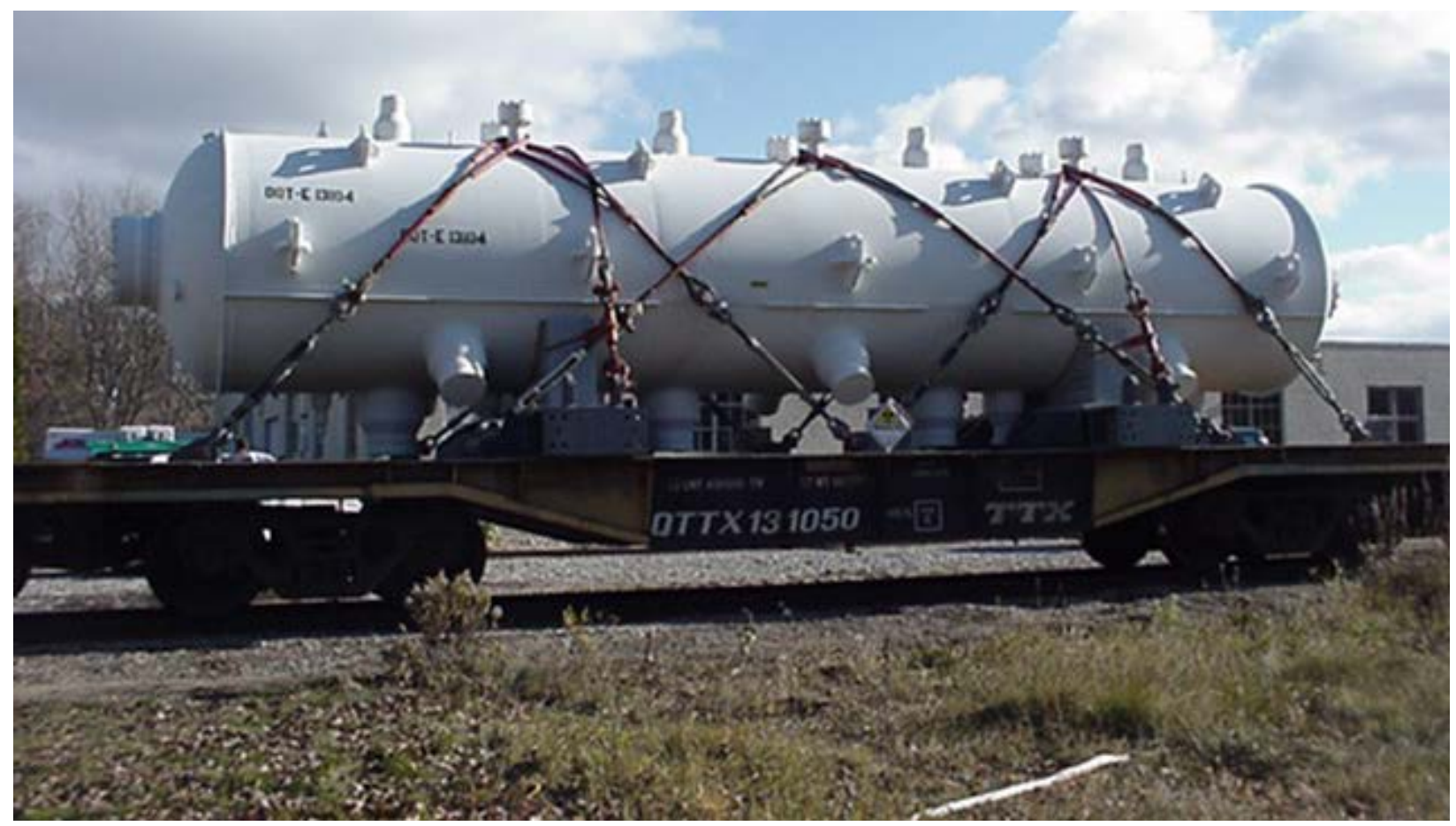

Figure 4-18. Big Rock Point Steam Drum on Railcar 
In 1999 and 2001, the steam domes and pressurizer removed during demolition of the Connecticut Yankee (Haddam Neck) nuclear power plant were moved 12 miles from the plant site over local roads to the Portland railhead near Middletown, Connecticut. A total of five heavy haul truck shipments were made. Figure 4-19 shows the pressurizer on its heavy haul truck transporter and Figure 4-20 shows the route taken from the Connecticut Yankee site to the Portland railhead. This railhead connects via a bridge across the Connecticut River to the Providence and Worcester (P\&W) Railroad. Figure 4-21 shows the pressurizer at the Portland railhead and Figure 4-22 shows the current condition of the Portland railhead.

If heavy haul trucks were used to move casks containing used nuclear fuel from the Connecticut Yankee site to the Middletown area railhead, the P\&W Railroad, which is a Class II railroad, would then haul the shipments to Hartford, Connecticut. In the Hartford area, the shipments would be switched to the Pan Am Southern Railroad, the same railroad that operates the rail line that passes near the Yankee Rowe site.

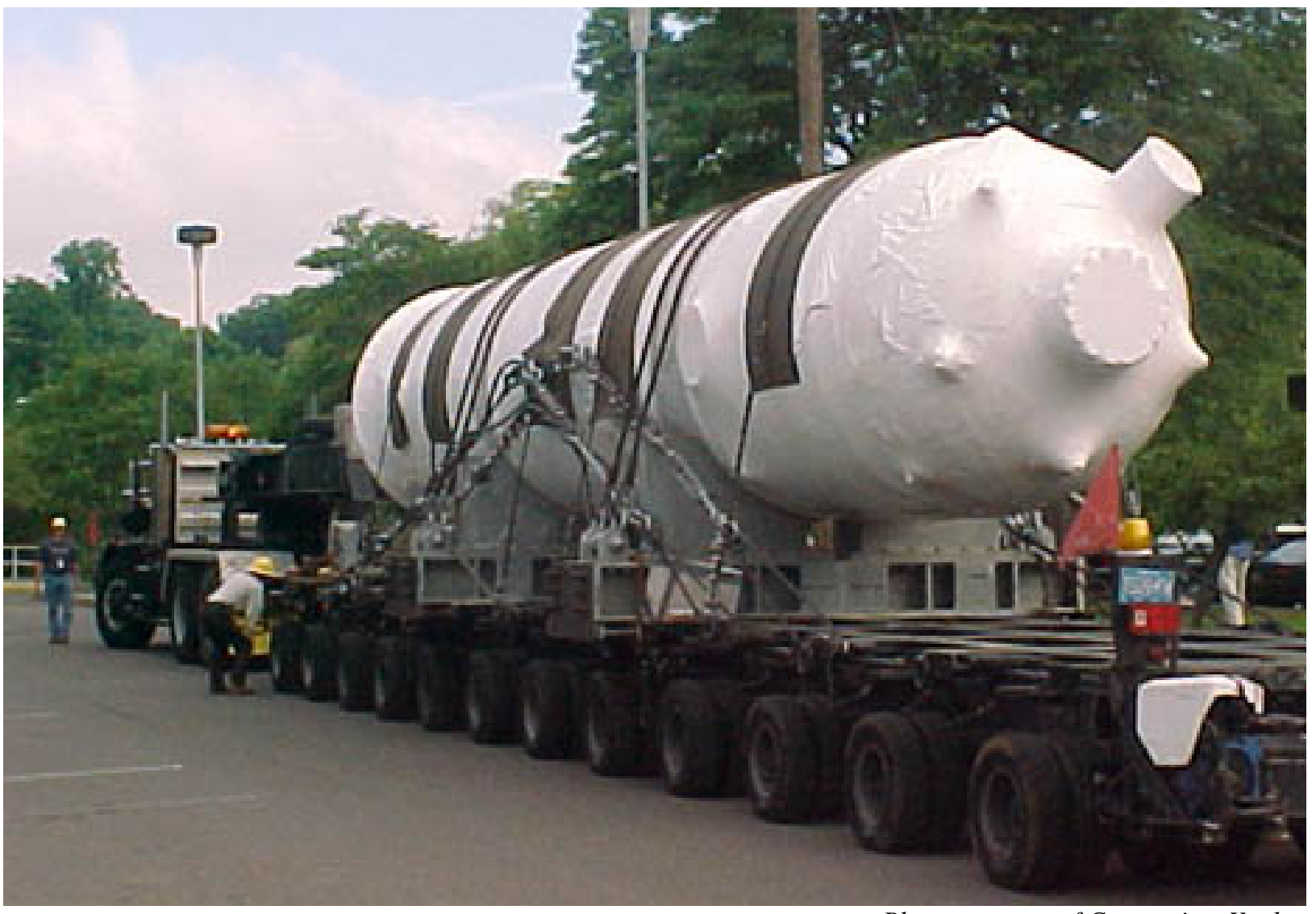

Figure 4-19. Connecticut Yankee Pressurizer on Heavy Haul Truck Transporter 


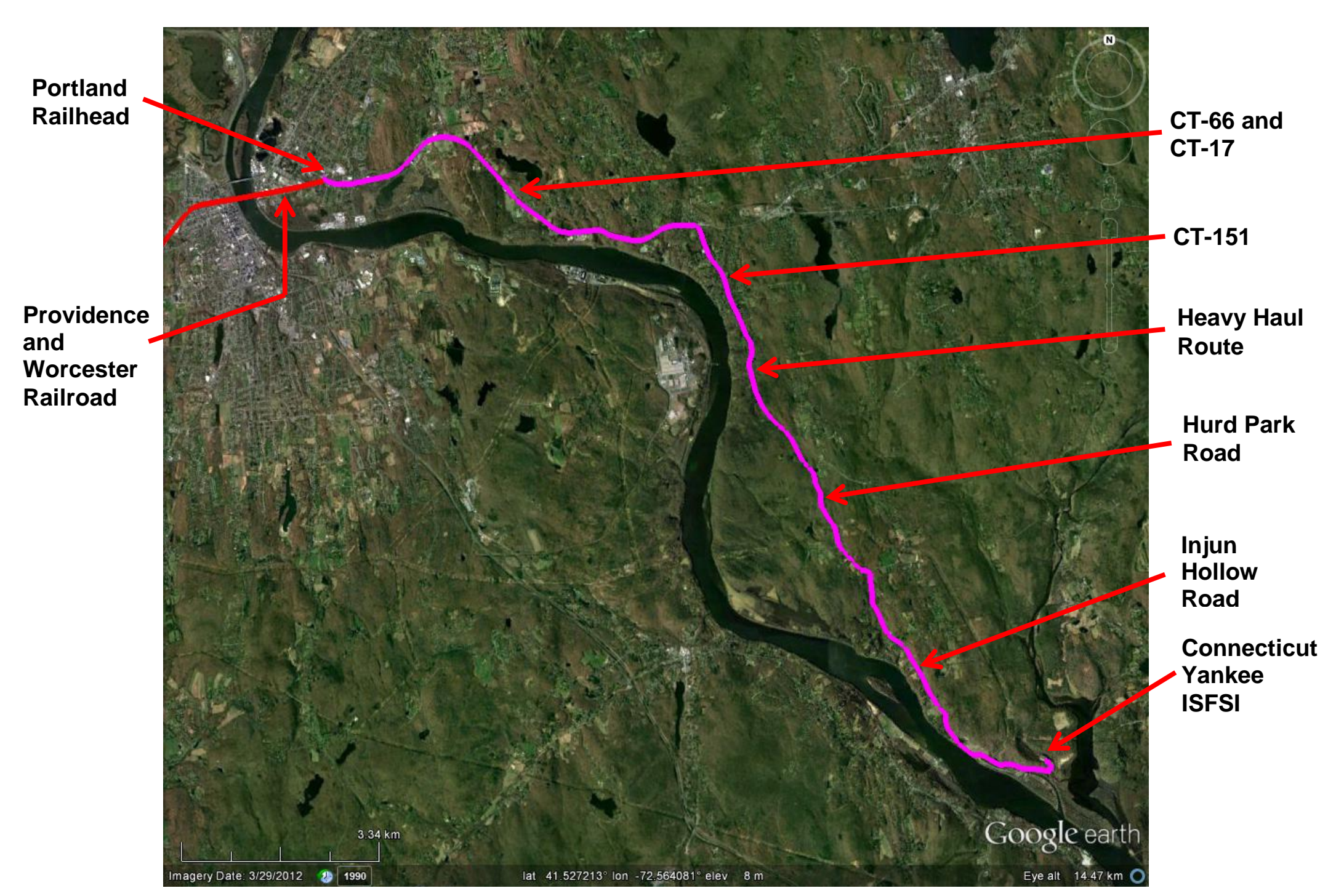

Figure 4-20. Connecticut Yankee Heavy Haul Truck Route (Google 2012) 


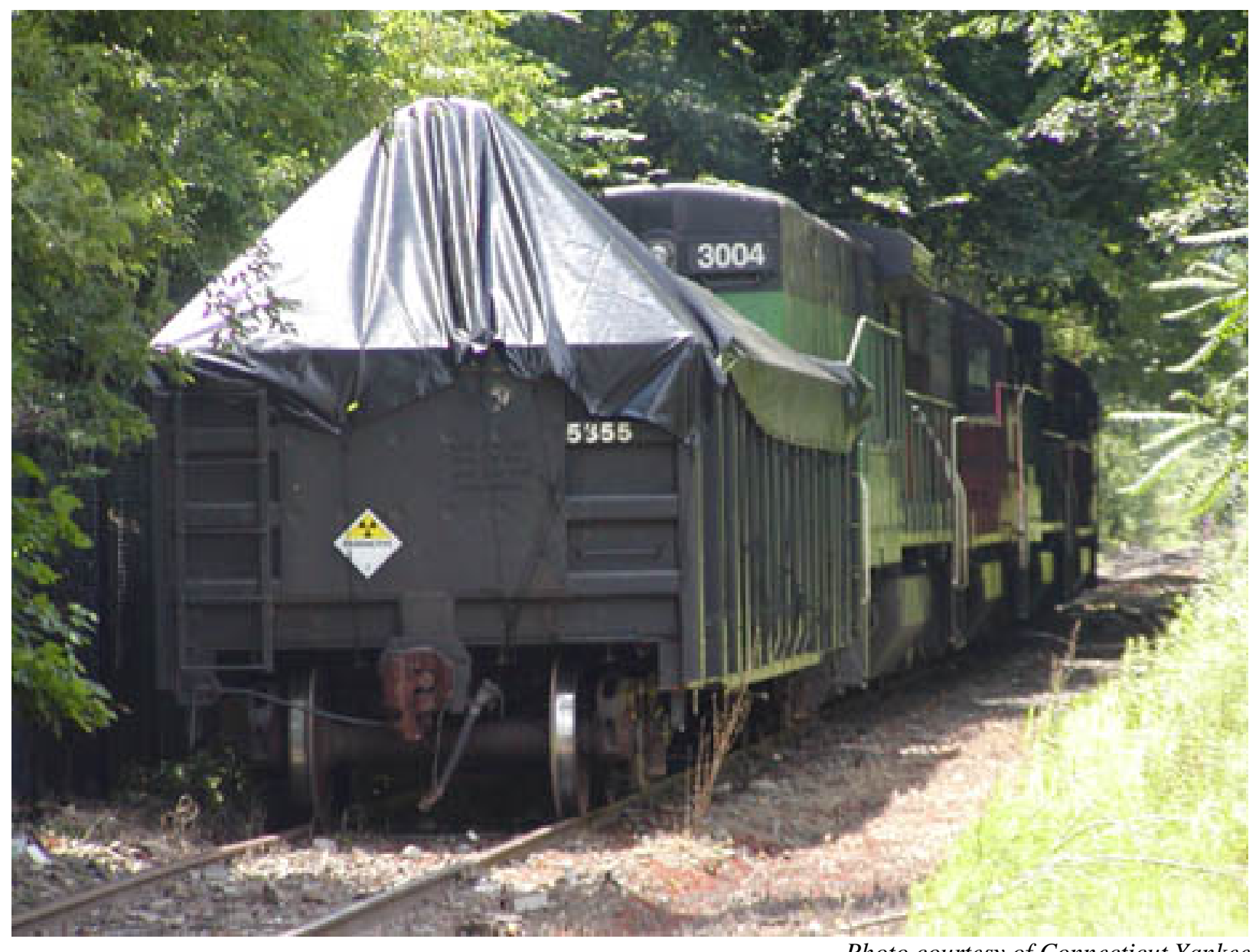

Figure 4-21. Connecticut Yankee Pressurizer at Portland Railhead 


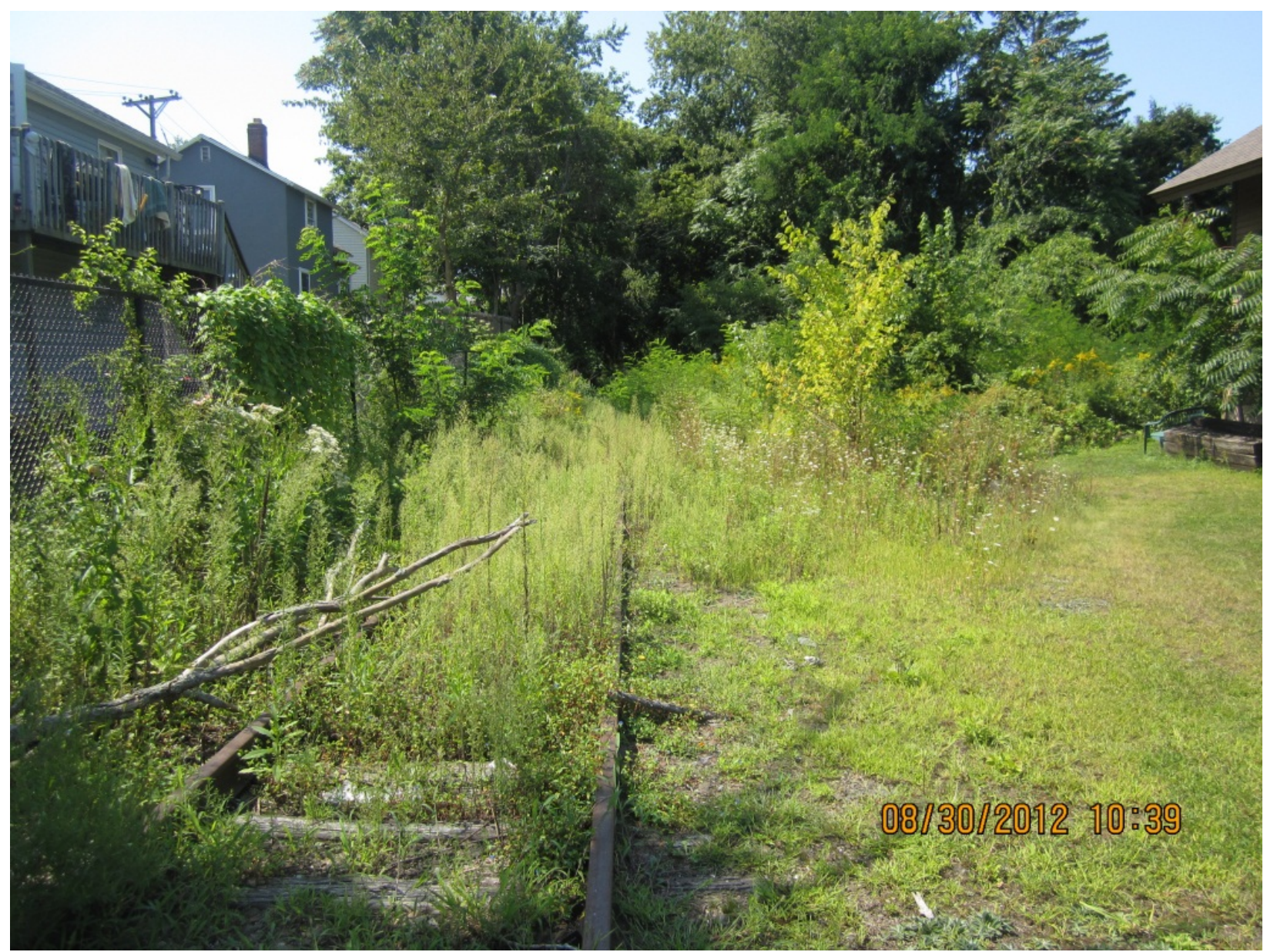

Figure 4-22. Current Condition of Portland Railhead

In 2011, ZionSolutions, which is decommissioning the Zion reactors, shipped the Zion Unit 2 reactor head from the Zion site to Clive, Utah for disposal. The reactor head was approximately 17 feet in diameter and weighed 225,000 lb. (Troher 2011). A heavy haul truck was used for this shipment because the Zion Unit 2 reactor head was too large for shipment by rail. The heavy haul truck travelled 1,500 miles from the Zion site north of Chicago, Illinois to the EnergySolutions disposal facility in Clive, Utah. Figure 4-23 shows the Zion reactor head on its heavy haul truck transporter. 


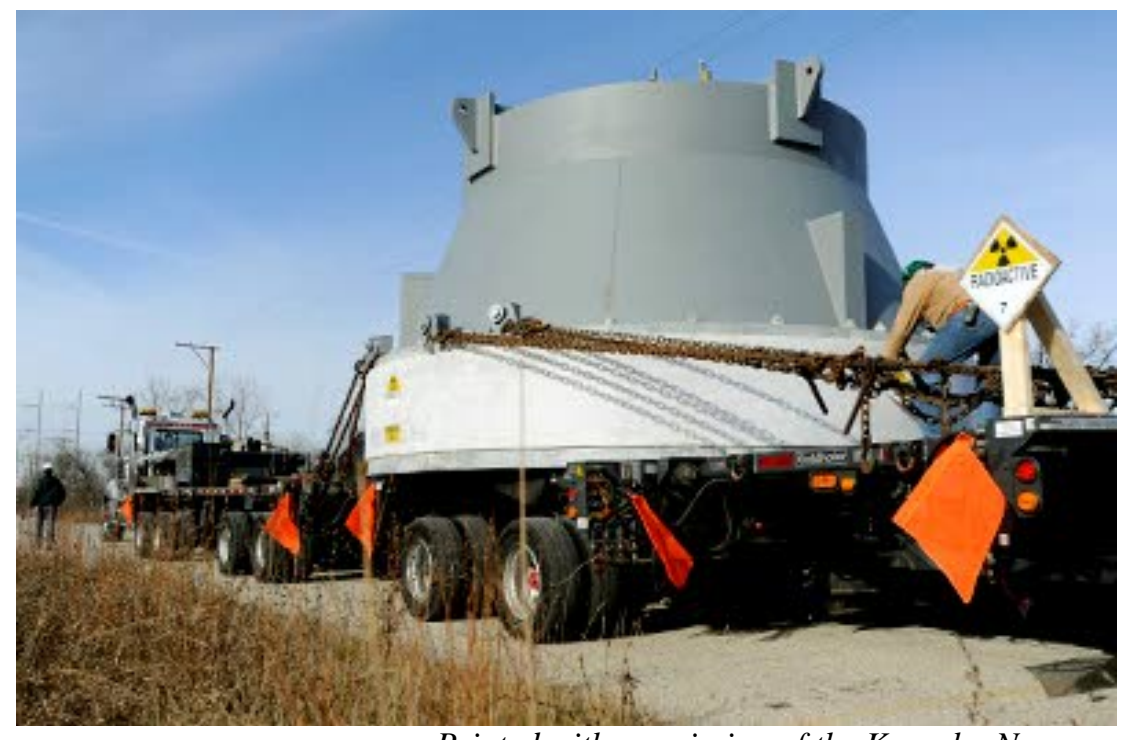

Printed with permission of the Kenosha News

Figure 4-23. Zion Reactor Head on Heavy Haul Truck Transporter

\subsubsection{Barge Transport from Shutdown Sites to Port or Railhead}

The Maine Yankee, Connecticut Yankee, Humboldt Bay, Big Rock Point, Trojan, La Crosse, and Zion shutdown sites are located on the shores of navigable waterways and therefore could be accessible by barges that would transport used nuclear fuel transportation casks to nearby ports served by railroads or to barge-accessible railheads. The Maine Yankee, Connecticut Yankee, Trojan, and La Crosse sites all have onsite barge areas. These barge areas are shown in Figures 3-1, 3-6, 3-11, and 3-12. At Connecticut Yankee, the onsite barge sidings and docks were removed after decommissioning and would have to be reconstructed prior to use. It may also be necessary to dredge the cooling water discharge canal to ensure that it is deep enough for the barges.

As discussed in Section 3.1, during decommissioning at Maine Yankee, three steam generators, the pressurizer, and reactor pressure vessel were transported offsite using barges. Figures 4-24 and 4-25 show the Maine Yankee reactor pressure vessel being loaded onto a barge and being transported by barge.

As discussed in Section 3.3, during decommissioning at Connecticut Yankee, the reactor pressure vessel, steam generators, and transformer were transported offsite using barges. Figures 4-26 through 4-28 show the Connecticut Yankee reactor pressure vessel being loaded onto a barge and being transported by barge.

As discussed in Section 3.7, during decommissioning at Trojan, four steam generators, the pressurizer, and the reactor pressure vessel were transported by barge to the US Ecology low-level radioactive waste disposal facility near Richland, Washington. Figures 4-29 through 4-32 show a steam generator being loaded at the Trojan barge slip, and the Trojan reactor pressure vessel being transported by barge, passing through locks on the Columbia River, and 
being transported by heavy haul truck to the US Ecology low-level radioactive waste disposal facility.

It is possible that barges could be brought up to the shorelines of the Big Rock Point and Humboldt Bay sites. Big Rock Point had an onsite barge facility that was used during construction and that would have to be reestablished (see Figure 4-33). This would likely involve grading and spreading gravel. In addition, Lake Michigan is subject to freezing in the Big Rock Point area (TOPO 1994a), which could limit operations. DSI (2004) identifies the following ports with rail access:

- Traverse City, Manistee, Muskegon, and Grand Haven as ports with rail access along the eastern shore of Lake Michigan

- Alpena, Bay City Port Huron, and Detroit as ports with rail access along the western shore of Lake Huron

- Inland, Escanaba, Green Bay, and Milwaukee as ports with rail access along the western shore of Lake Michigan

- Chicago, Indiana Harbor, Buffington, and Gary as ports with rail access along the southern shore of Lake Michigan.

The capabilities of these ports have not been investigated.

The Port of Humboldt Bay is located on the coast of northern California, approximately 225 nautical miles north of San Francisco and approximately 156 nautical miles south of Coos Bay, Oregon (USACE 2012). Humboldt Bay is the only harbor between San Francisco and Coos Bay with deep-draft channels large enough to permit the passage of large commercial oceangoing vessels. It is the second largest coastal estuary in California (USACE 2012). Humboldt Bay is reported to have seven shipping terminals: Fairhaven Terminal, Humboldt Bay Forest Products Docks, Fields Landing Terminal, Redwood Marine Terminal, Schneider Dock, Sierra Pacific Eureka Dock, and the Simpson Mill Wharf Port Facility (HBHRCD 2012). The U.S. Army Corps of Engineers dredges shipping channels in and into Humboldt Bay to depths of 35 to 40 feet. DSI (2004) identifies San Francisco Bay and Coos Bay as the closest ports to Humboldt Bay with rail access.

The Fields Landing Terminal (see Figures 4-34 and 4-35) is approximately 2 miles south of the Humboldt Bay site. The Fields Landing Channel is 12,000 feet long and 300 feet wide, with an 800-foot-long, 600-foot-wide turning basin (USACE 2012). As discussed in AC\&T (2011) and Bragg Crane and Rigging, ${ }^{11}$ barges were used to move 10 Wartsila engines weighing 680,000 lb. each and 10 generators weighing 165,000 lb. each to the Fields Landing Terminal. Heavy haul trucks then moved the engines and generators from the terminal to the Humboldt Bay Generating Station. Figure 4-34 also shows the heavy haul route taken from the Field Landing Terminal to

\footnotetext{
${ }^{11}$ Maheras SJ. 2012. Email message from A Richards (Senior Project Manager/Special Projects, Bragg Crane \& Rigging) to SJ Maheras (Pacific Northwest National Laboratory), “Andy Richards / Bragg Crane \& Rigging,” October 17, 2012.
} 
the Humboldt Bay Generating Station. Figures 4-36 through 4-40 show a Wartsila engine being loaded on a barge, a barge and Wartsila engine being towed to the Fields Landing Terminal, a barge and Wartsila engine arriving at the Fields Landing Terminal, a Wartsila engine being unloaded from the barge, and a Wartsila engine being transported by heavy haul truck to the Humboldt Bay Generating Station.

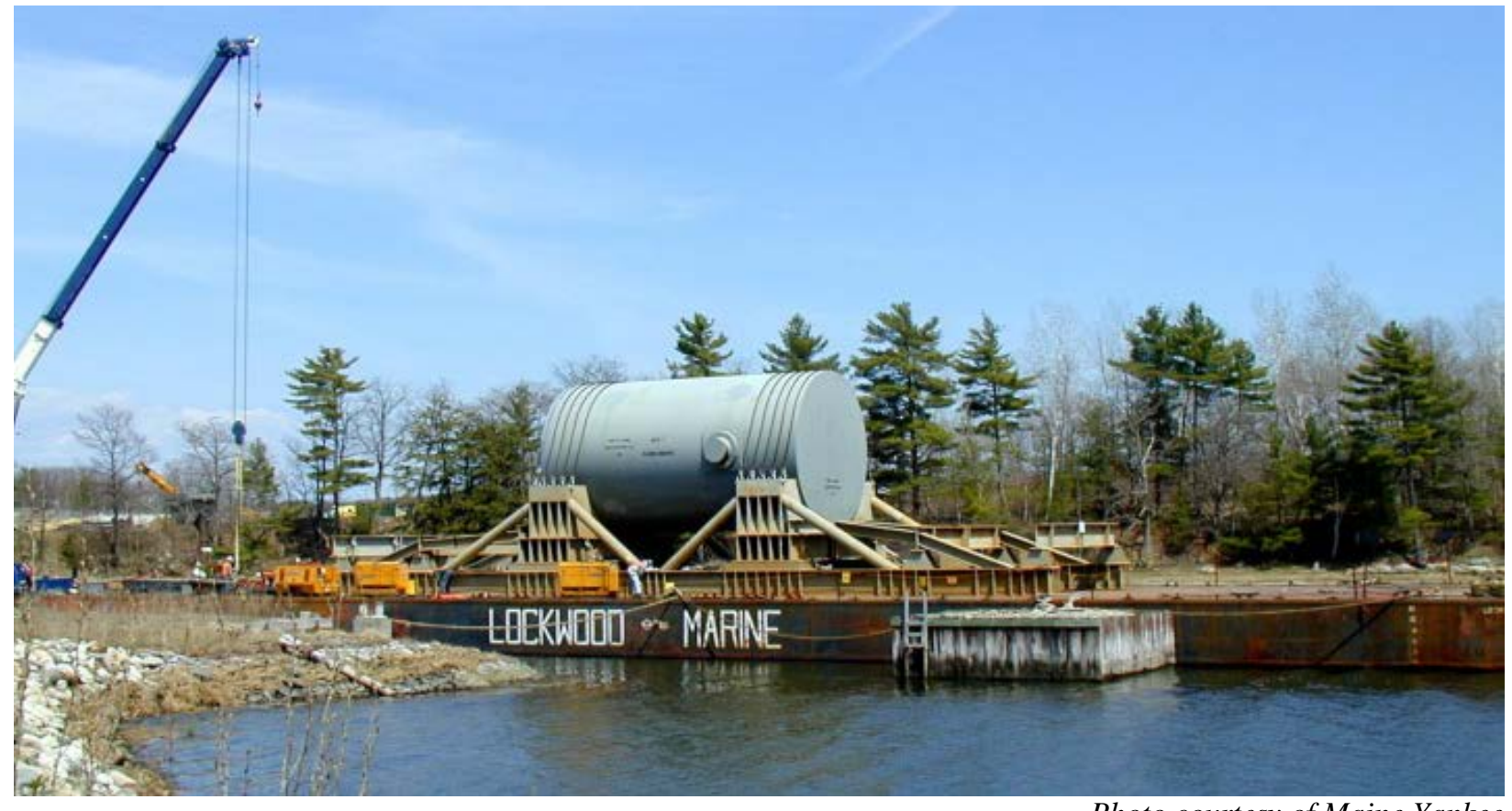

Figure 4-24. Maine Yankee Reactor Pressure Vessel Being Loaded onto Barge

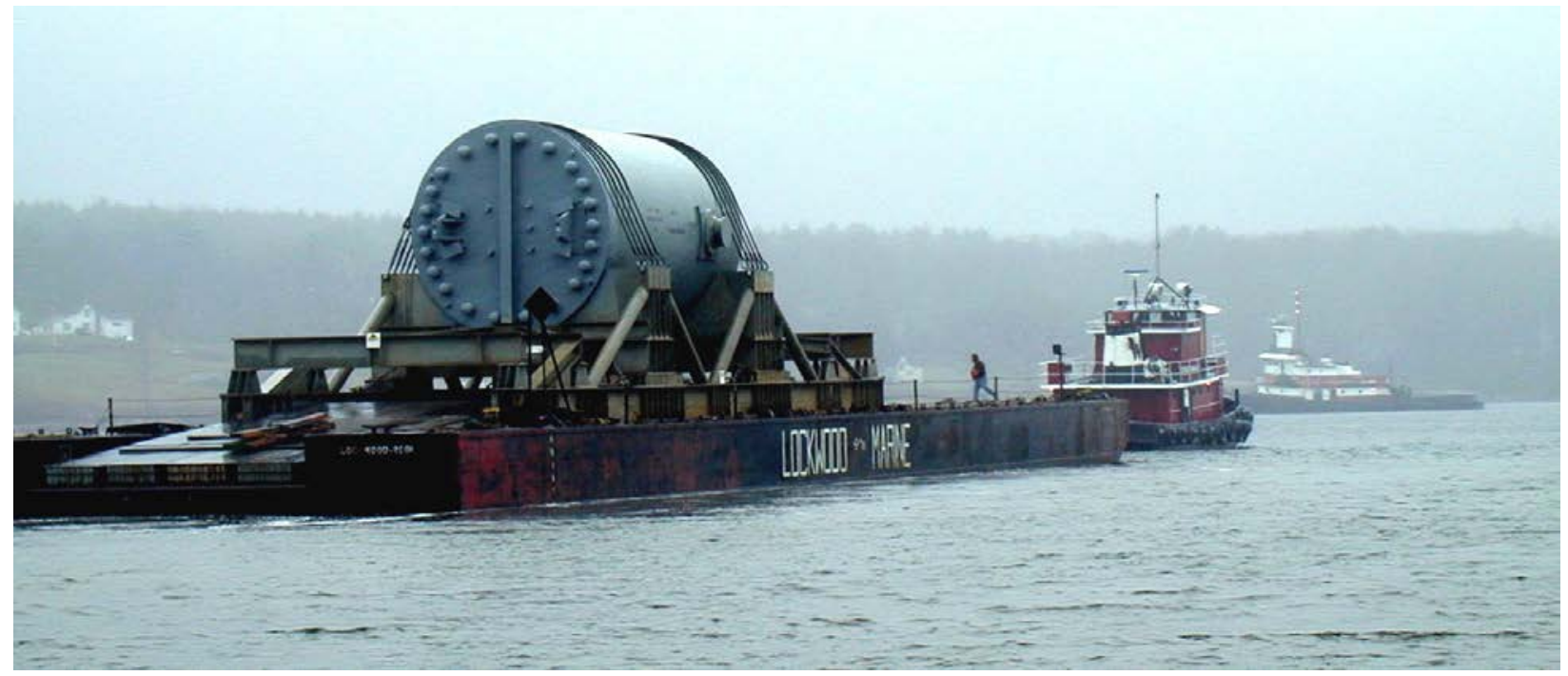

Photo courtesy of Maine Yankee

Figure 4-25. Maine Yankee Reactor Pressure Vessel Being Transported on Barge 


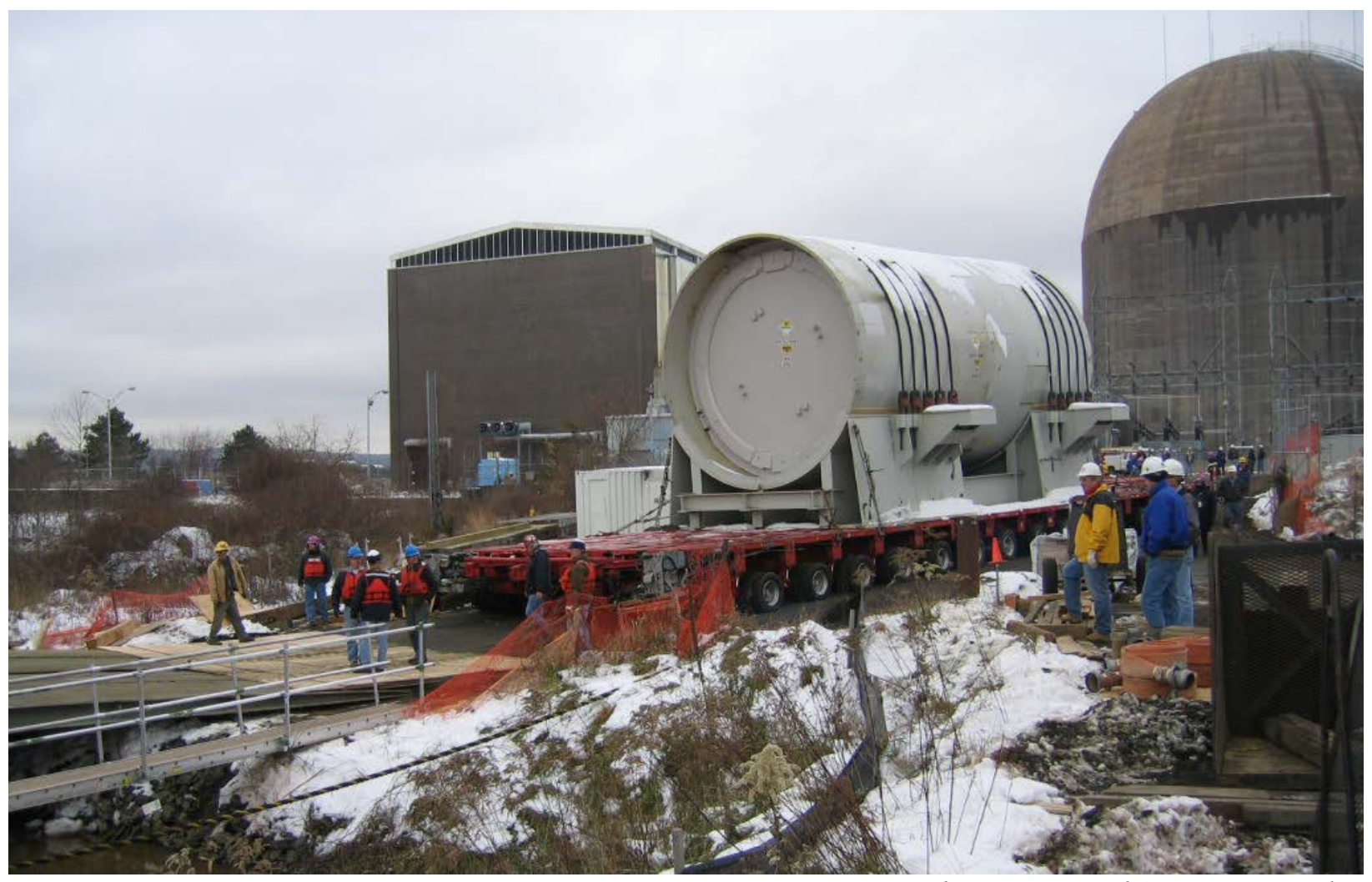

Photo courtesy of Connecticut Yankee

Figure 4-26. Connecticut Yankee Reactor Pressure Vessel Being Loaded onto Barge 


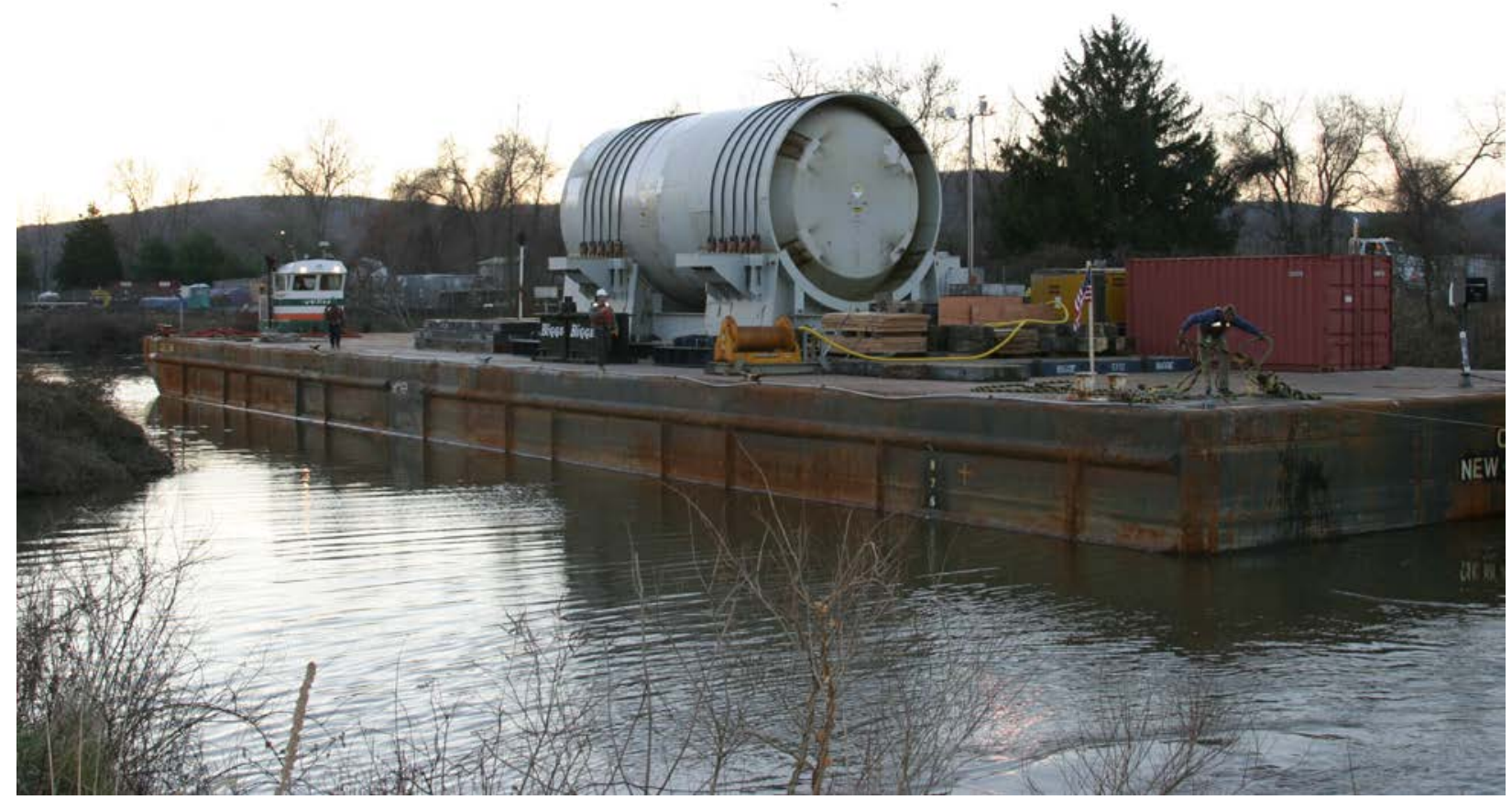

Photo courtesy of Connecticut Yankee

Figure 4-27. Connecticut Yankee Reactor Pressure Vessel Being Transported on Barge

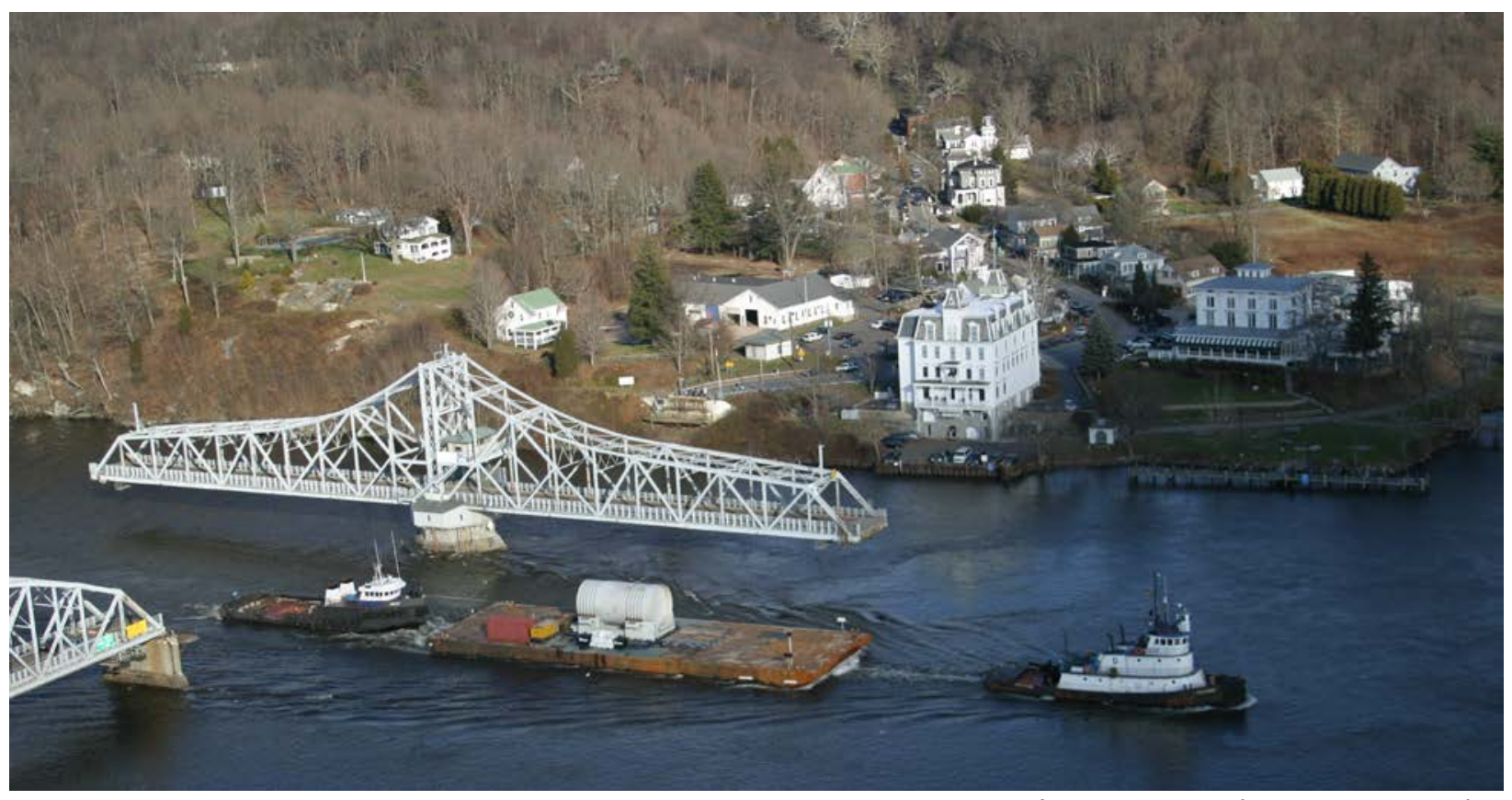

Photo courtesy of Connecticut Yankee

Figure 4-28. Connecticut Yankee Reactor Pressure Vessel Being Transported on Barge in the Connecticut River 


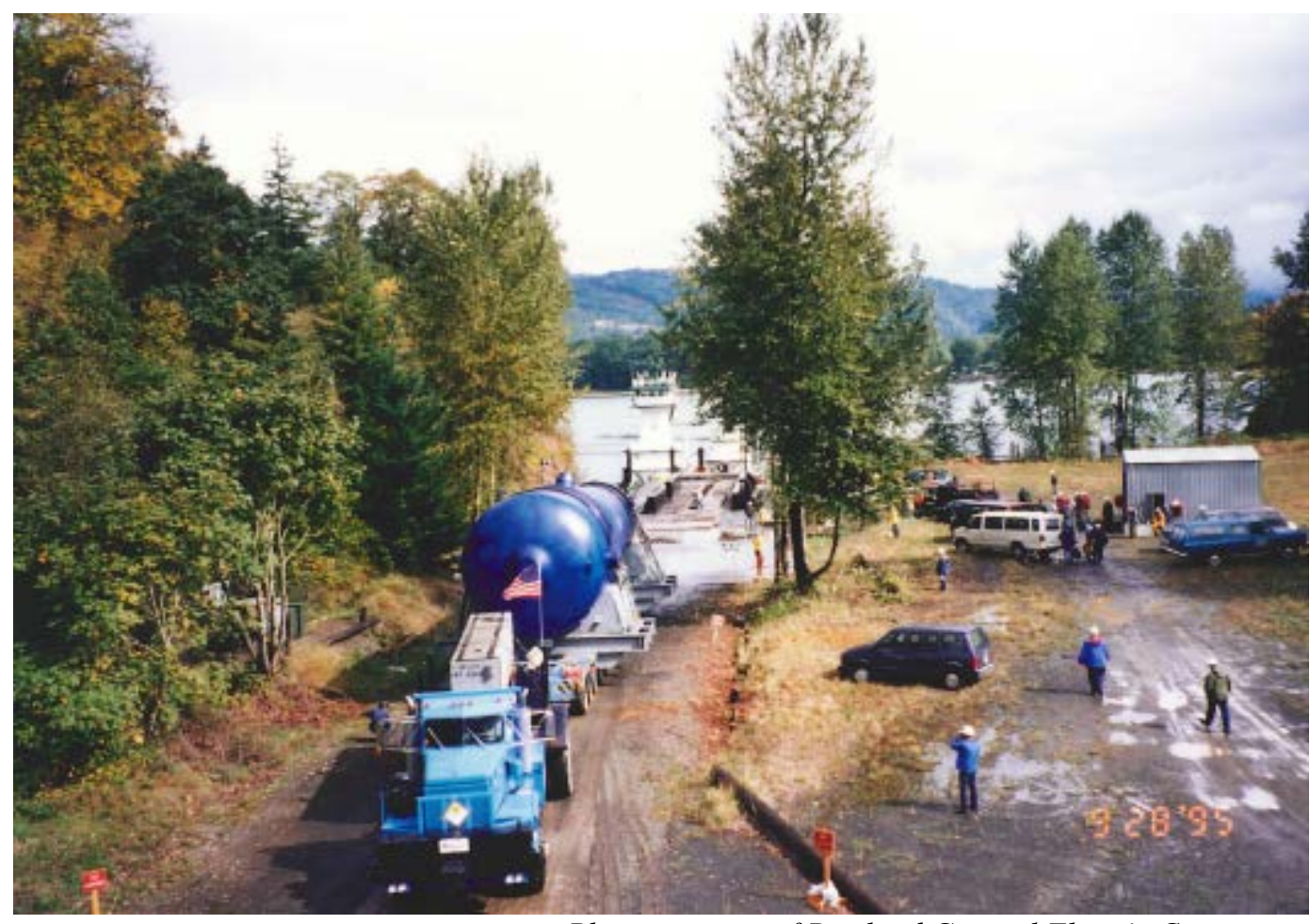

Photo courtesy of Portland General Electric Company

Figure 4-29. Trojan Steam Generator Being Loaded at Barge Slip

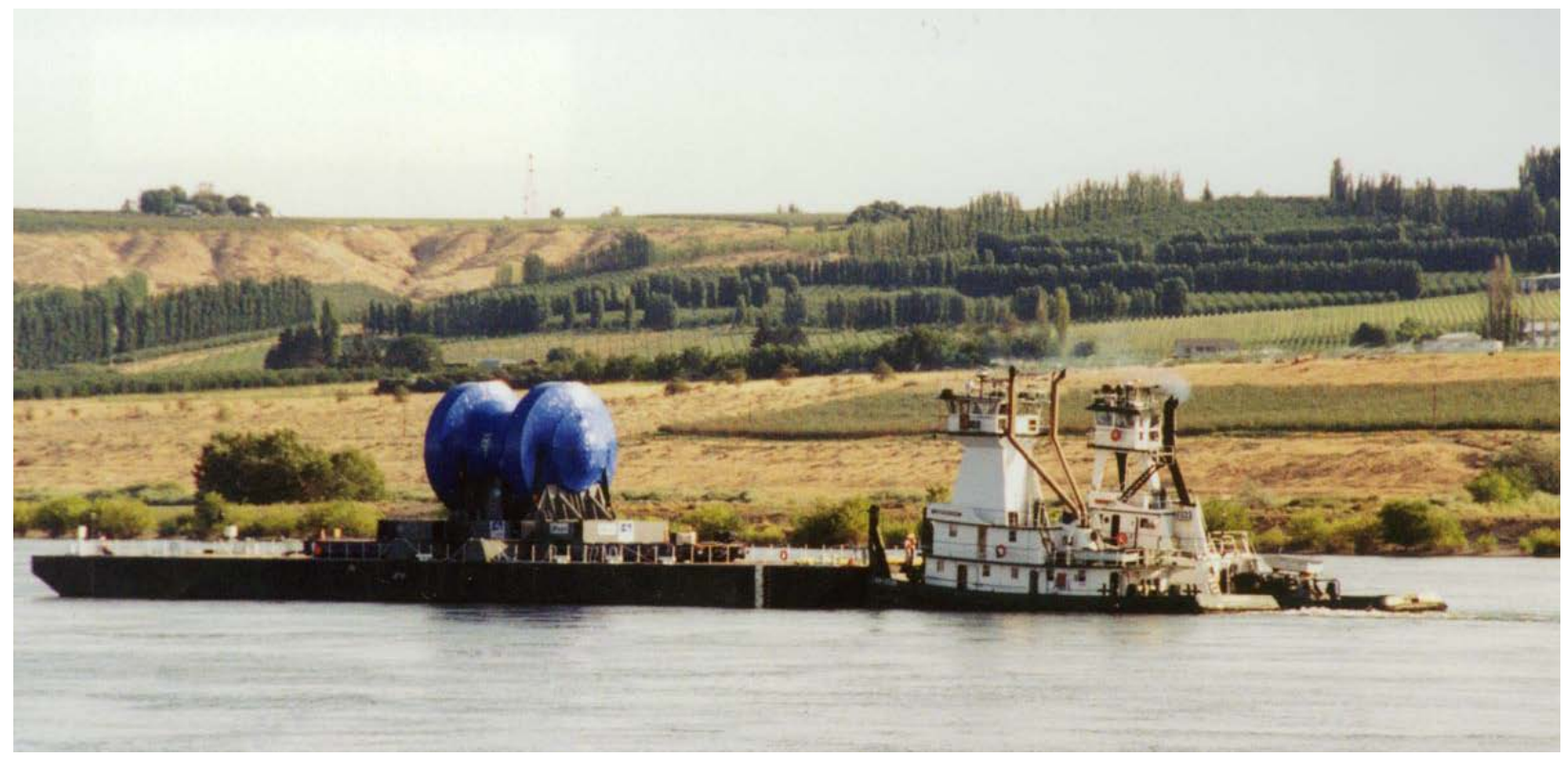

Photo courtesy of Portland General Electric Company

Figure 4-30. Trojan Reactor Pressure Vessel Being Transported by Barge 


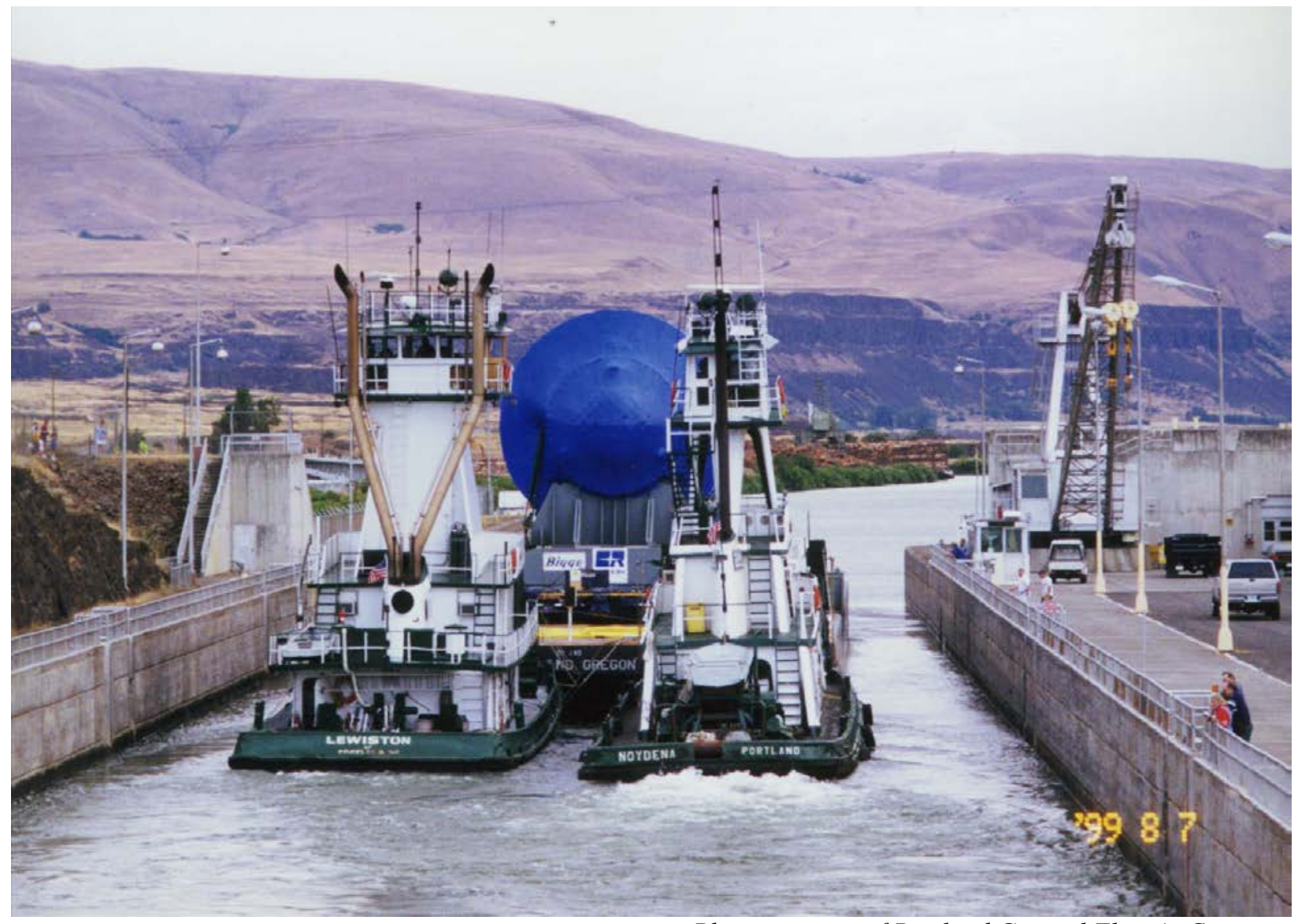

Photo courtesy of Portland General Electric Company

Figure 4-31. Trojan Reactor Pressure Vessel Passing Through Locks on the Columbia River

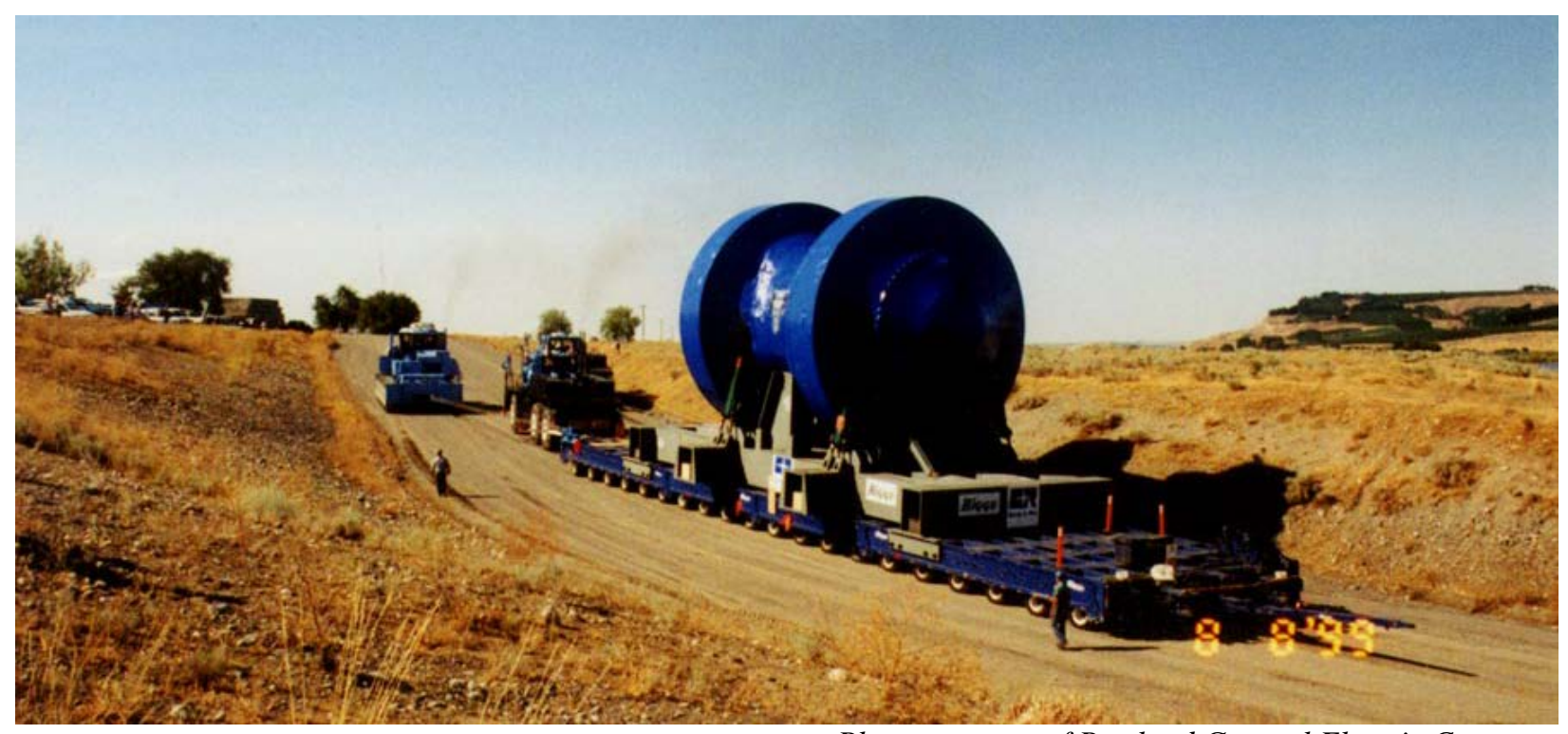

Photo courtesy of Portland General Electric Company Figure 4-32. Trojan Reactor Pressure Vessel Being Transported by Heavy Haul Truck 


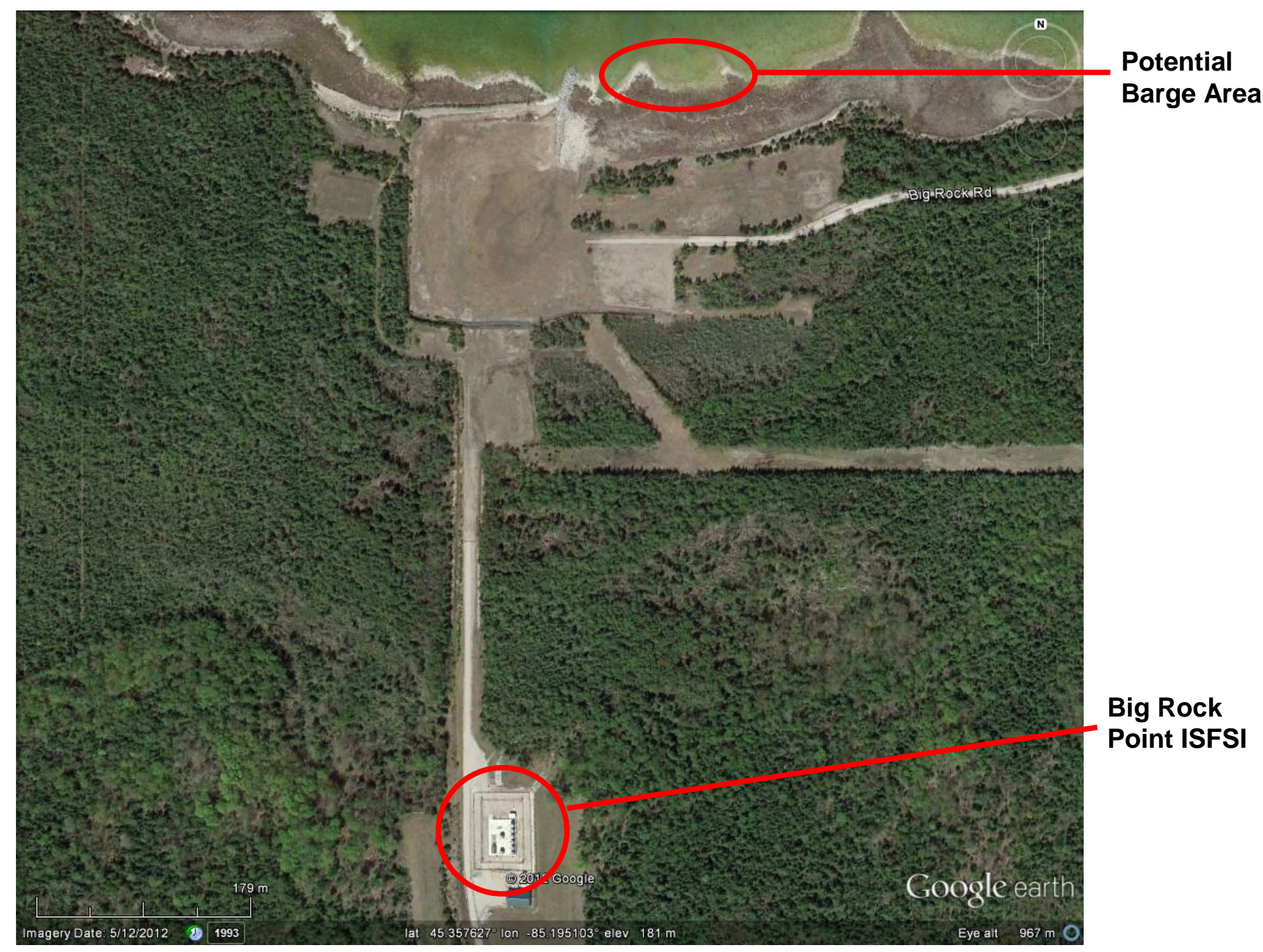

Figure 4-33. Big Rock Point ISFSI and Potential Barge Area (Google 2012) 


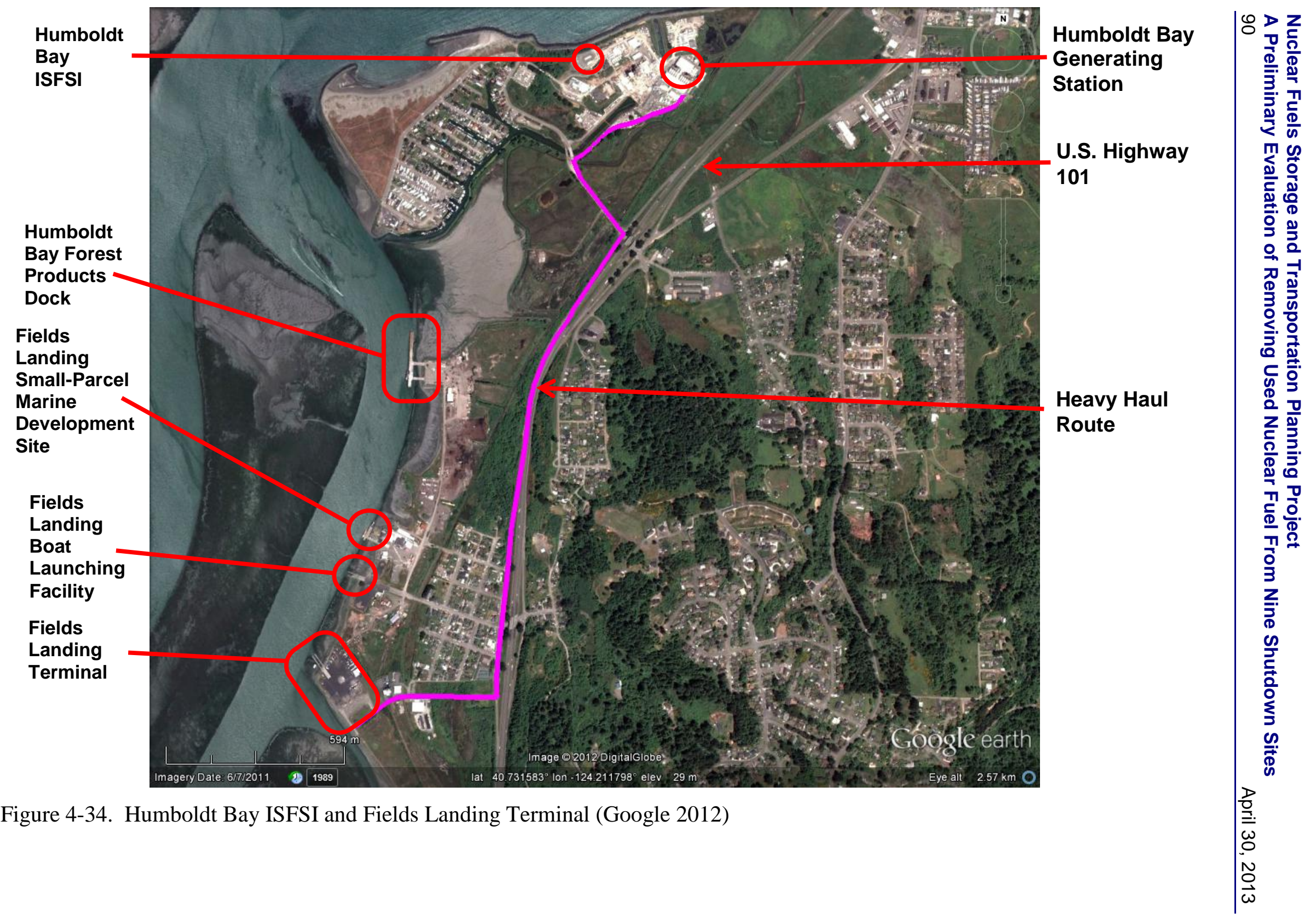



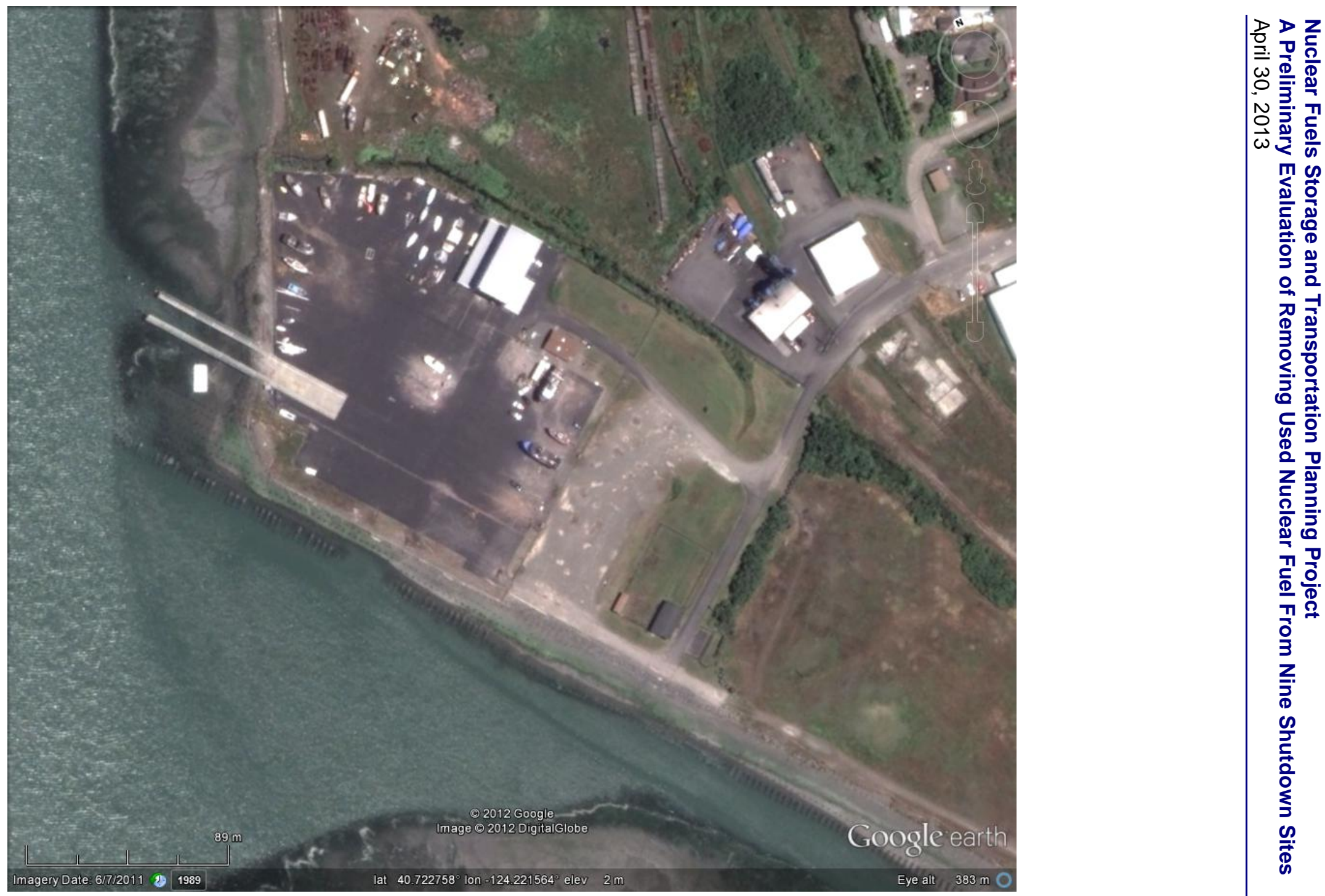

Figure 4-35. Fields Landing Terminal (Google 2012) 


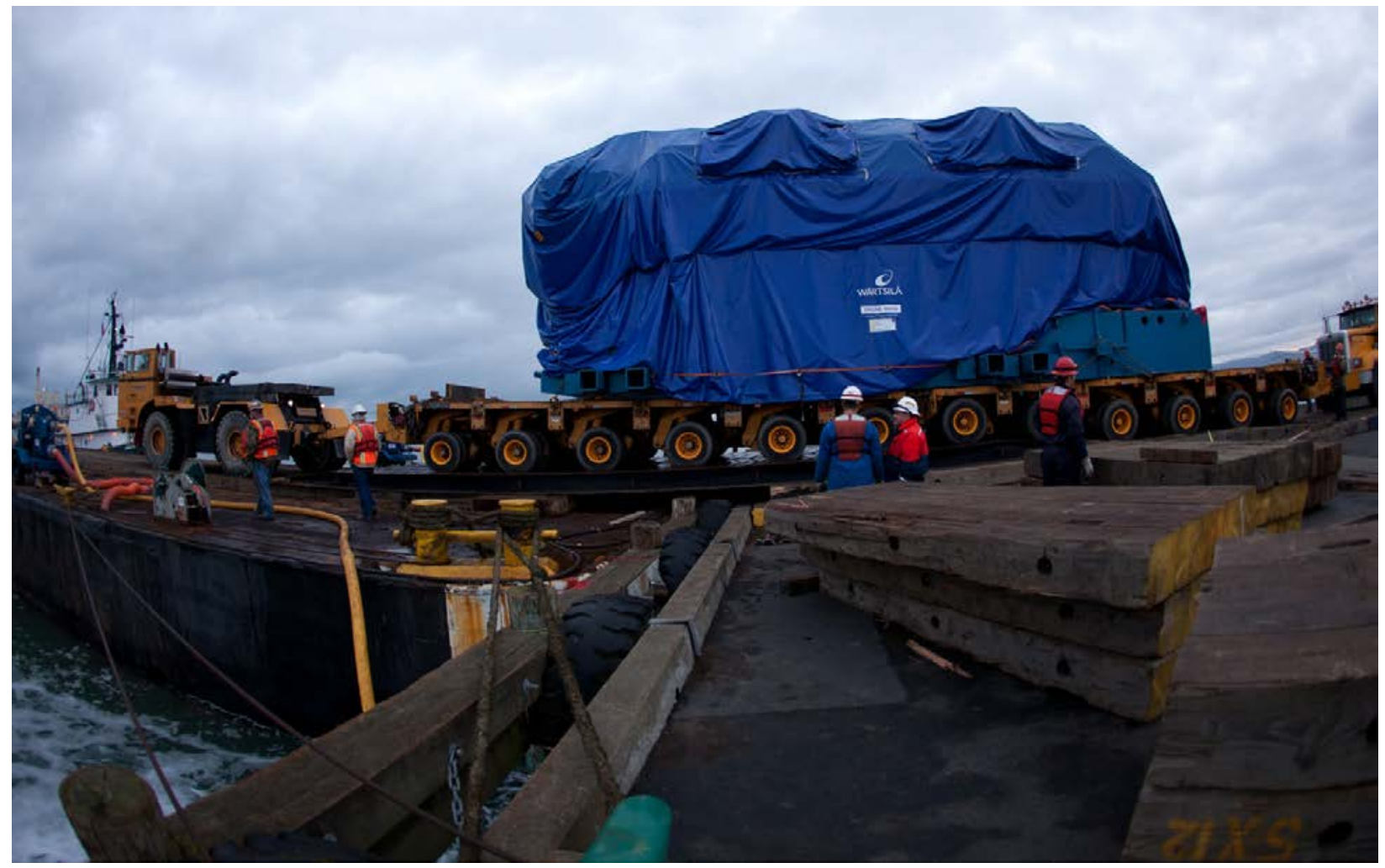

Figure 4-36. Wartsila Engine Being Loaded on a Barge

Photo courtesy of Bragg Crane \& Rigging Co. 


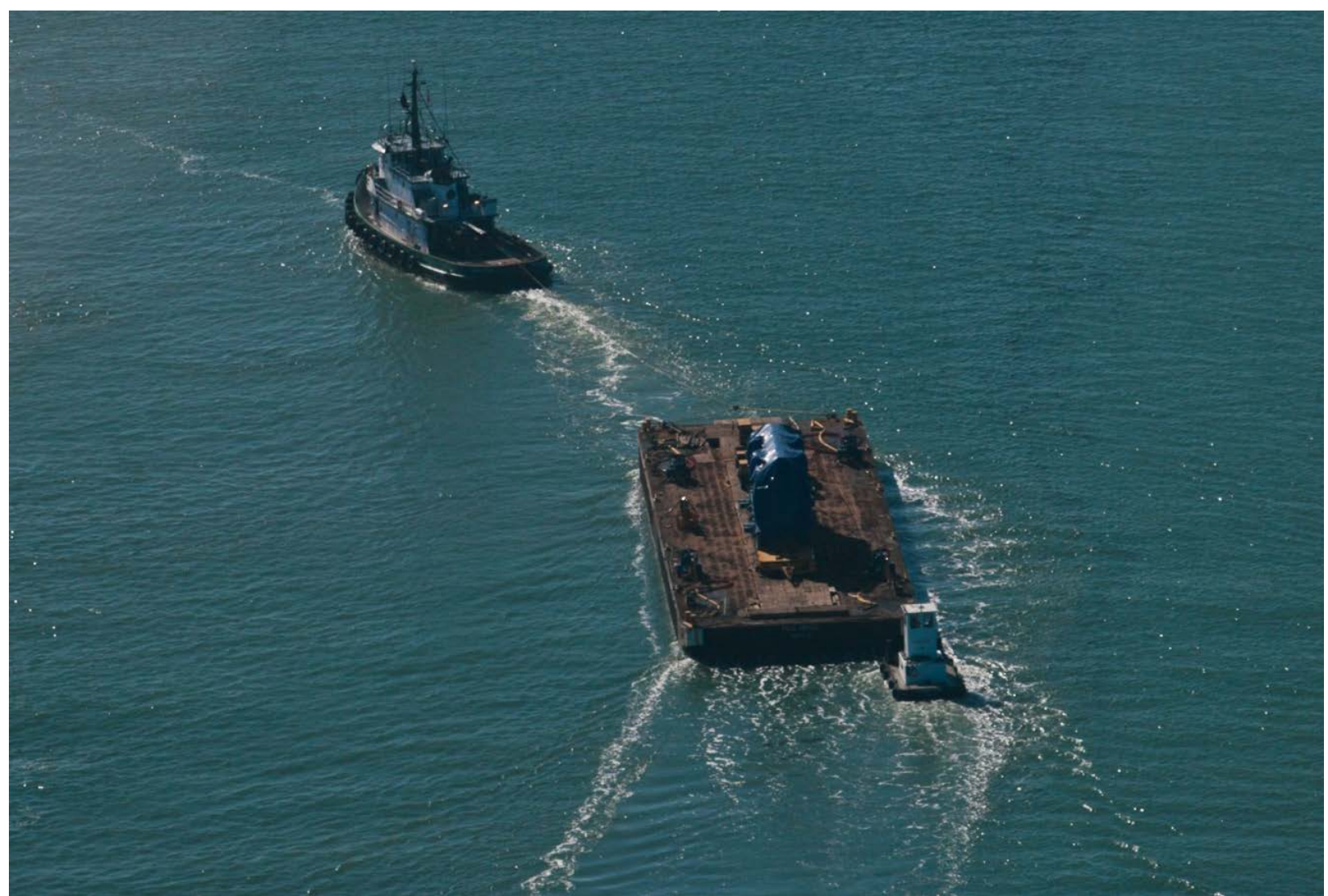

Photo courtesy of Bragg Crane \& Rigging Co.

Figure 4-37. Wartsila Engine on a Barge Being Towed to Fields Landing Terminal 


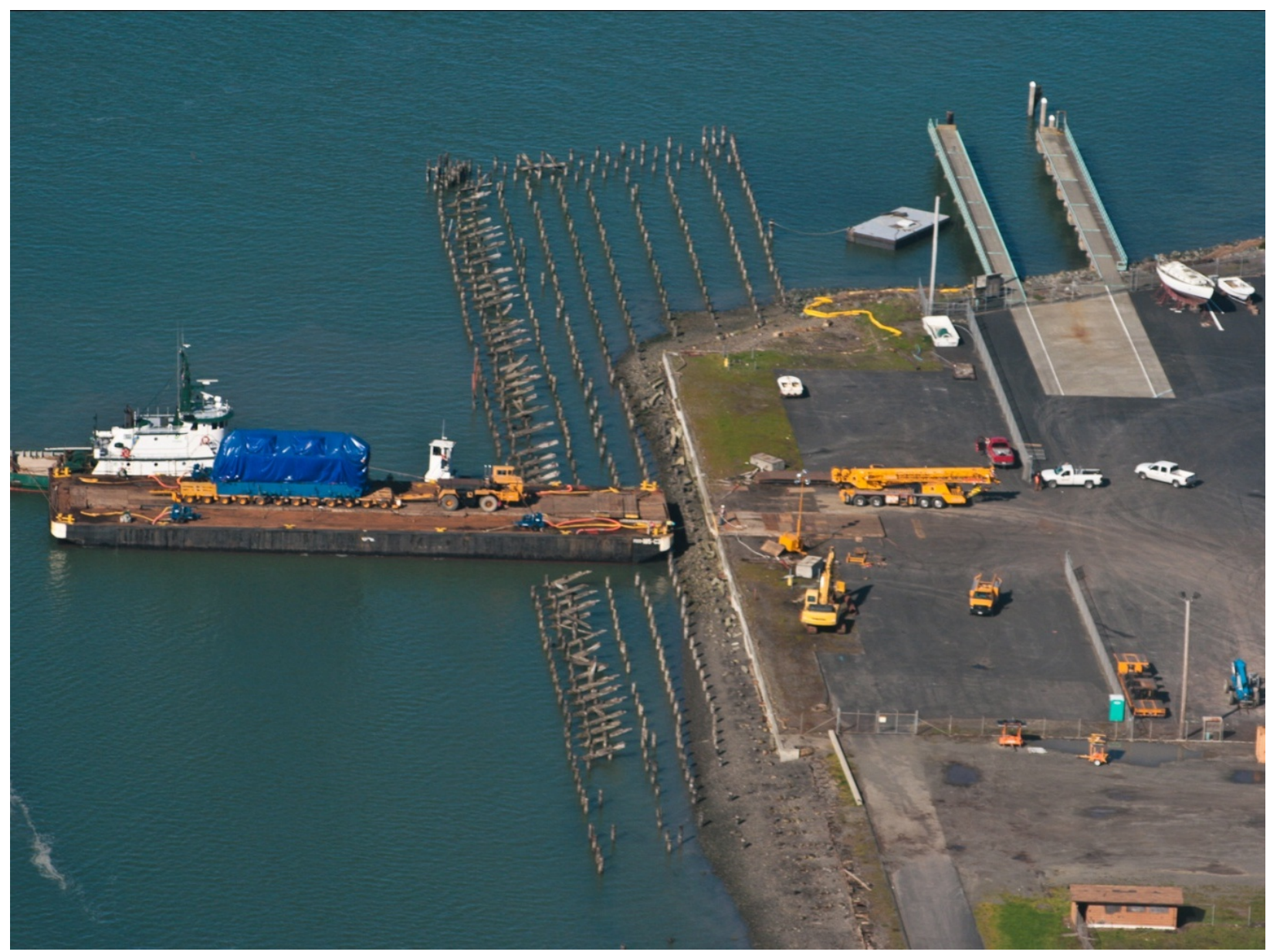

Photo courtesy of Bragg Crane \& Rigging Co.

Figure 4-38. Barge with Wartsila Engine Arriving at Fields Landing Terminal 


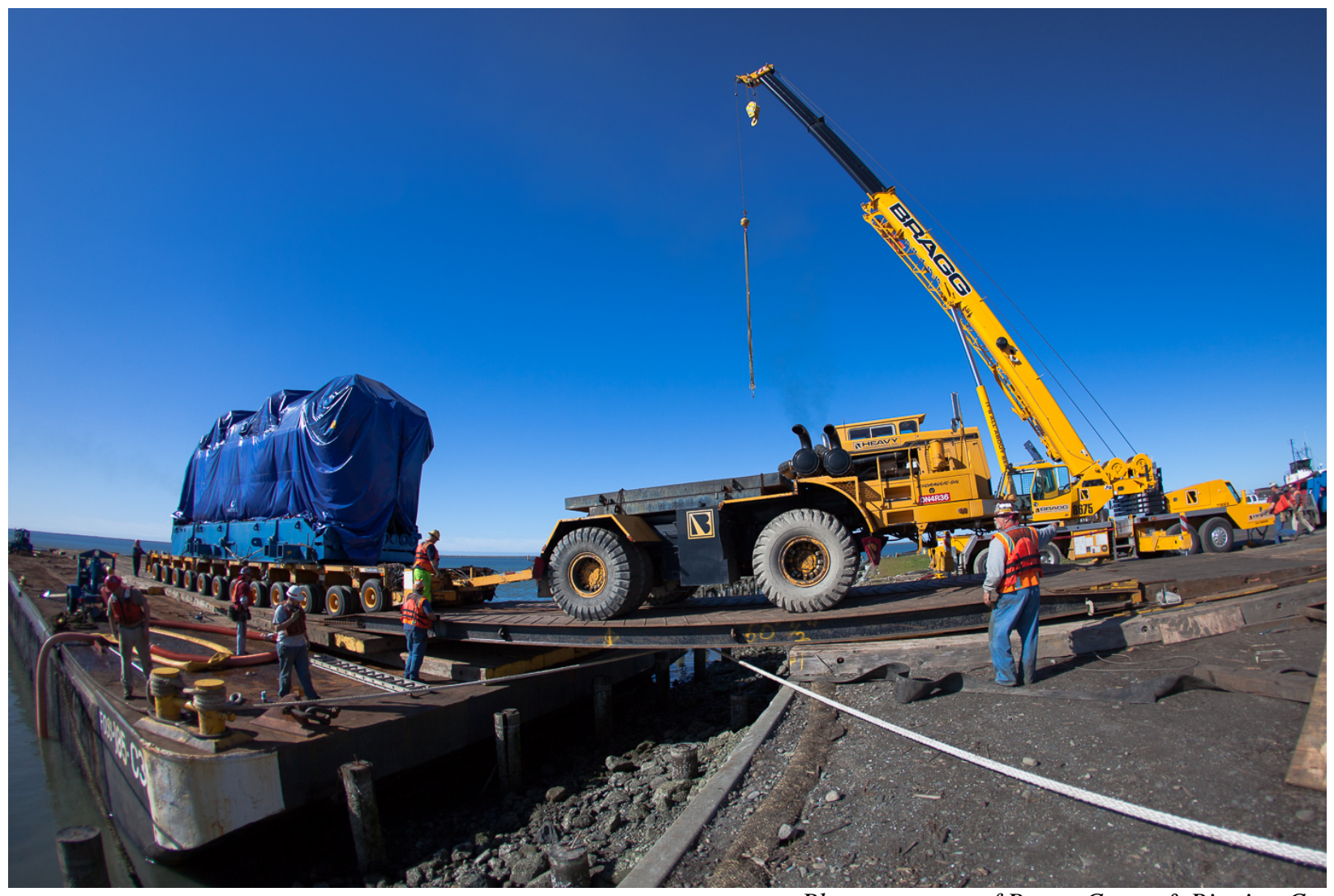

Photo courtesy of Bragg Crane \& Rigging Co.

Figure 4-39. Wartsila Engine Being Unloaded at Fields Landing Terminal 


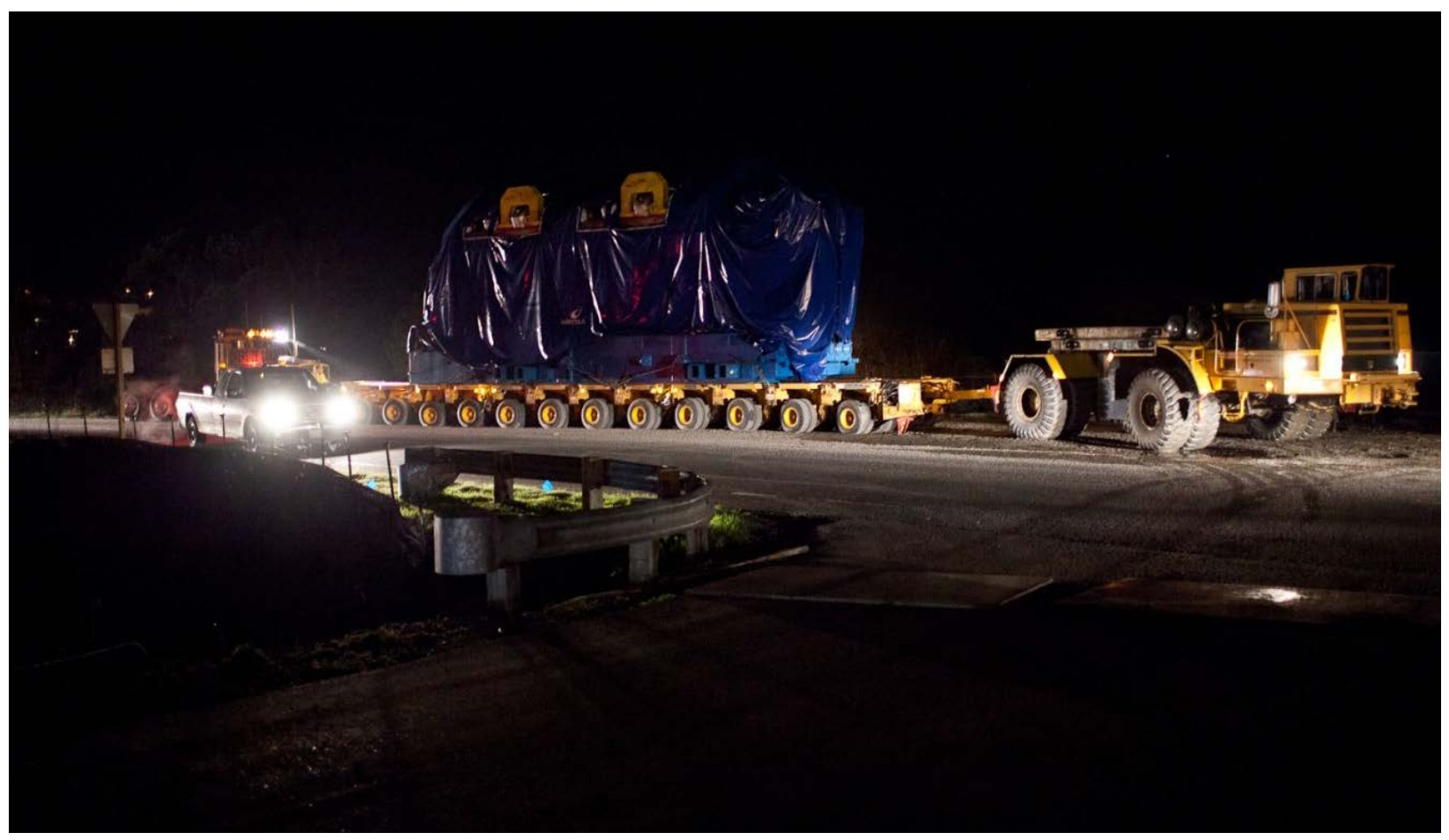

Photo courtesy of Bragg Crane \& Rigging Co.

Figure 4-40. Wartsila Engine Being Transported by Heavy Haul Truck to Humboldt Bay Generating Station

For sites that are directly accessible by barge (Maine Yankee, Connecticut Yankee, Trojan, La Crosse, and Zion), transportation casks would be loaded, prepared for offsite transportation, and placed onto transport skids/cradles. Because the locations of ISFSIs are not immediately adjacent to barge sidings/docks, heavy-lift equipment would be used to place the casks and transport skids/cradles onto heavy haul vehicles for transport from the ISFSI to the onsite barge siding/dock. Heavy-lift equipment would then transfer the casks from the heavy haul vehicles onto the deck of the transporting barges. Alternatively, the heavy haul transport vehicles with their transport casks could roll onto the barge, thereby not requiring heavy-lift capability at the siding/dock to move the casks from the heavy haul truck to the barge.

For the Humboldt Bay site, if it is not practical or acceptable to move shipments onto barges at the shoreline on the site, it may be possible to use heavy haul trucks to move the shipments on local roadways for about two miles to the Fields Landing Terminal where they could be loaded onto barges for shipment along the Pacific coast to a port that is served by a railroad.

For sites where barges were beached at the shoreline versus being docked, it is likely that the roll-on/roll-off method for loading shipments onto barges would be used. Roll-off from a beached barge has been used to move reactor pressure vessels on shore from barges near the Barnwell, South Carolina low-level radioactive waste disposal facility. 


\subsection{Summary of Gaps in Information Regarding Offsite Transportation Infrastructure for Nine Shutdown Sites}

Notwithstanding what is known about the capabilities of offsite transportation infrastructure at the nine shutdown sites, there are questions that will need to be addressed before transportation modes can be determined and shipments of used nuclear fuel from the sites can be undertaken. The questions that apply to the nine sites are discussed in the following sections.

\subsubsection{Maine Yankee Site}

The principal question for the Maine Yankee site regarding the capability of the offsite transportation infrastructure to accommodate shipments of large transportation casks is whether the Maine Eastern Railroad is capable of accepting and moving used nuclear fuel railcars. An assessment by the Federal Railroad Administration's track safety engineers and of the Maine Eastern Railroad's maintenance-of-way staff would be necessary. If the railroad's infrastructure cannot accommodate the shipments, it would be necessary to ship casks on barges from the site to a port where they would be transferred to railcars. Because the Maine Yankee reactor pressure vessel was shipped from the site by barge, there is substantial confidence that barges could be used to move used nuclear fuel casks from the site. Nonetheless, it would be necessary to obtain a marine engineer's assessment of the condition of the channel leading to the Maine Yankee barge siding and to do any dredging and restoration of navigation aids in the channel that may be necessary.

\subsubsection{Yankee Rowe}

The Yankee Rowe site is located inland in the western part of Massachusetts and thus does not have access to a navigable waterway. In addition, the rail spur that once led from the local railroad to the site has been removed and cannot be reinstalled because the construction of the Cockwell (formerly Bear Swamp) Pumped Storage Plant resulted in submersion of the rail line to Yankee Rowe (TOPO 1993b). Consequently, it would be necessary to transport casks containing used nuclear fuel from the site for a distance of about 7.5 miles over a local, improved road to the nearest location for a rail siding at the eastern portal of the Hoosac Tunnel. This would require crossing the Sherman Dam. The road and heavy haul transport were used to move the Yankee Rowe reactor pressure vessel to the Hoosac Tunnel location in 1997. This heavy haul truck route can be ice covered at times during the winter and could need treatment to prepare it for shipments. The siding that was installed at the tunnel for the purpose of loading the reactor pressure vessel onto a railcar has been removed and would need to be reinstalled before shipments of casks to this location could take place. Alternative routing for heavy haul trucks that would lead to North Adams, Massachusetts where casks could be loaded onto railcars, would require travel north over mountainous local roads into Vermont then south to the North Adams area, a distance of about 20 miles.

There is sufficient land in the Hoosac Tunnel area to stage handling equipment. This is based on the use of this area to load the reactor pressure vessel from the transporter to the railcar. However, site preparation work would most likely be required. The available space is limited for 
a rail siding at the Hoosac Tunnel location, making it likely that only one or two railcars could be placed for loading. It would be necessary to move loaded railcars from the siding to a staging area, possibly in North Adams, where trains with possibly two locomotives, buffer cars, and an escort car could be assembled. A staging location has not been identified.

\subsubsection{Connecticut Yankee}

The Yankee Companies site managers for the Connecticut Yankee site suggested that shipments of used nuclear fuel casks from the site should use barges. The onsite barge sidings and docks were removed after decommissioning and would have to be reconstructed prior to use. It may also be necessary to dredge the cooling water discharge canal to ensure that it is deep enough for the barges. In addition, the cooling water discharge canal and the Connecticut River can freeze in the winter.

Should it be necessary to use heavy haul trucks to move casks from the site, it would be necessary to work with local authorities to determine local routing and heavy haul truck operations procedures and schedules that would minimize disruption of traffic flow and other community activities in the moderately populated area. In addition, the heavy haul truck route from the Connecticut Yankee site to Portland, Connecticut can be ice covered at times during the winter and could need treatment to prepare it for shipments. It would also be necessary to work with the owners of the railhead to improve track structures from their current degraded condition to allow the transfer of casks from heavy haul trucks to railcars.

\subsubsection{Humboldt Bay}

Offsite transportation of HI-STAR HB transportation casks from the Humboldt Bay ISFSI site would require either use of heavy haul trucks for transport over 160 miles of two-lane roads that traverse California coastal mountainous roads or use of barges to ship the casks to a port on the western U.S. coast that is served by a railroad.

As discussed in Section 3.4, the Humboldt Bay site has not been served by rail since 1998. In 2011, the Northwestern Pacific Railroad reopened as far north as Windsor, California, about 220 miles south of the Humboldt Bay site. The North Coast Railroad Authority hopes to have the rail line open to Willits, California by 2020, which is still about 140 miles south of the Humboldt Bay site. The nearest railhead is located in Redding, California, a distance of about 160 miles from Humboldt Bay. The 160-mile trip on public highways from the site would entail travel on U.S. Highway 101 through Eureka, connecting to California Highway 299 to travel east across the coastal mountains to Redding, California. This route is illustrated in Figure 4-41. In Redding, heavy-lift equipment would be used to transfer casks from heavy haul trucks onto railcars that would be moved on the Union Pacific mainline that passes through the Redding area. One-way travel time for the heavy haul truck shipments could be greater than one week. It is likely that two of the heavy haul trucks would be moved in convoy in order to limit the overall impact on commuter traffic and business traffic that use the roads. Substantial coordination and planning of the shipments with local and California state officials would be necessary. Prior to the shipments highway engineers would need to survey the roads and road structures (bridges, culverts, and 
overpasses) to ensure that the shipments could be conducted safely. It is possible that temporary or even permanent improvements, such as adding passing lanes, would need to be made to sections of the roads and structures before the shipments could begin and travel might be limited to late spring through early fall because of weather and frost conditions on roads at higher elevations.

Alternative nearby railheads are located at Grants Pass, Oregon, and Williams, Marysville, and Red Bluff, California. Heavy haul truck routes to these railheads are illustrated in Figure 4-41. The distances to these railheads range from about 160 to 260 miles (see Table 4-1). Representatives of PG\&E have stated that heavy haul transport using U.S. Highway 101 and State Route 36 would be unacceptable.

Table 4-1. Alternative Railheads for Humboldt Bay

\begin{tabular}{llc}
\hline \multicolumn{1}{c}{ Railhead } & \multicolumn{1}{c}{ Route } & Heavy Haul Distance (miles) \\
\hline Grants Pass, Oregon & U.S. Highway 101 to U.S. Highway 199 & 180 \\
Redding, California & U.S. Highway 101 to State Route 299 & 160 \\
Red Bluff, California & U.S. Highway 101 to State Route 36 & 160 \\
Williams, California & U.S. Highway 101 to State Route 20 & 230 \\
Marysville, California & U.S. Highway 101 to State Route 20 & 260 \\
\hline
\end{tabular}

Additional heavy haul routes could potentially be used. For example, a heavy haul to Coos Bay, Oregon would be a distance of about 220 miles along U.S. Highway 101, a heavy haul to Windsor, California would be a distance of about 210 miles along U.S. Highway 101, a heavy haul to the San Francisco Bay Area would be a distance of about 240 miles, and a heavy haul to Sacramento, California would be a distance of about 290 miles along U.S. Highway 101, California Highway 20, and Interstate 5. A heavy haul to Willits, California would be a distance of about 130 miles along U.S. Highway 101, but the Northwestern Pacific Railroad is not open to Willits. In addition, it is not known if the Northwestern Pacific Railroad will handle hazardous material shipments. ${ }^{12}$

Barge transportation of used nuclear fuel casks from the Humboldt Bay site along the Pacific coast to a port facility that is served by a railroad may be the preferred alternative. However, the site does not have a barge siding or dock and it is uncertain whether barges could be landed at the shoreline of the site to allow roll-on of heavy haul trucks carrying the six HI-STAR HB casks. A marine survey would be needed to determine whether the depth of Humboldt Bay waters that approach the site and the bottom conditions near the shore would permit landing and securing a barge to the shoreline, safely loading it, and backing it back into a navigable channel in the bay. In addition, it is possible that approvals would be needed from California state authorities and from the U.S. Army Corps of Engineers before it would be possible to use a landed barge to load transportation casks containing used nuclear fuel.

\footnotetext{
${ }^{12}$ Used nuclear fuel and GTCC low-level radioactive waste would be Class 7 hazardous material.
} 
It may be possible to use heavy haul trucks to transport the casks to a nearby shipping terminal in Humboldt Bay. Humboldt Bay is reported to have seven shipping terminals: Fairhaven Terminal, Humboldt Bay Forest Products Docks, Fields Landing Terminal, Redwood Marine Terminal, Schneider Dock, Sierra Pacific Eureka Dock, and the Simpson Mill Wharf Port Facility (HBHRCD 2012). It would be necessary to determine which, if any, of the reported shipping terminals in Humboldt Bay could be used for shipments of the casks and what routing would be used by heavy haul trucks; however, 10 large engines and generators were delivered by barge into Humboldt Bay at the Fields Landing Terminal and were transported from the terminal to the Humboldt Bay site using heavy haul trucks (AC\&T 2011). Moving casks to the Fields Landing Terminal would involve travel over approximately 2 miles of roadways including about 0.5 mile of U.S. 101 and the remainder on local roadways. 


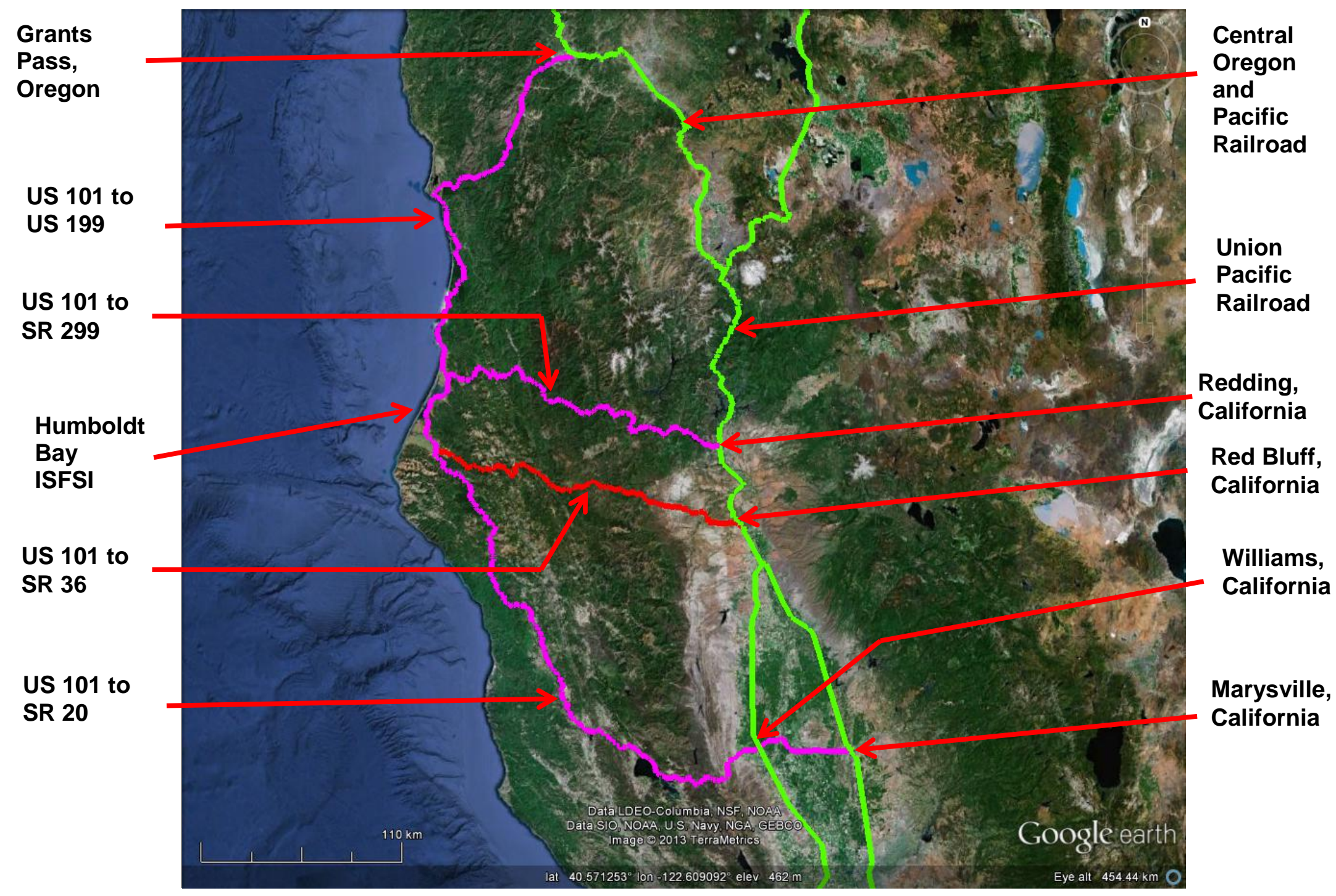

Figure 4-41. Heavy Haul Routes from Humboldt Bay ISFSI to Alternative Railheads (Google 2012) 


\subsubsection{Big Rock Point}

As discussed in Section 3.5, shipments of large reactor components have been made from the Big Rock Point site using heavy haul trucks to carry the components to rail sidings for loading onto railcars. It may also be possible to use barges to transport casks containing used nuclear fuel directly from the Big Rock Point site to a port that is served by a railroad. Barge shipment would require construction of a barge slip or dock on the site's Lake Michigan shoreline or alternatively, to use barges that could be landed on the shore and be secured. It would first be necessary to determine if the depth of water approaching the shore at the site and the bottom conditions near the shore would permit safe operations for barges. Barge operations could use either heavy lift equipment to move casks from heavy haul transporters onto barges or the heavy haul transporters might be rolled directly onto barges. Barge operations would not be conducted on Lake Michigan during winter months.

\subsubsection{Rancho Seco}

A 1-mile-long rail spur connects from the Rancho Seco site to the Union Pacific Railroad mainline. Rancho Seco is located in the Central Valley of California, and does not have access to a navigable waterway. Assuming that the onsite rail spur is maintained or improved as may be needed; it is unlikely that it would be necessary to use heavy haul trucks to move casks containing used nuclear fuel to a siding that might be installed along the Union Pacific mainline.

\subsubsection{Trojan}

Both rail and barge modes are feasible for transporting used nuclear fuel from the Trojan site. The Portland and Western Railroad rail line passes through the Trojan site approximately 700 feet from the Trojan ISFSI. In the past, a rail spur came into the protected area. The spur was disconnected, but could be rebuilt in preparation for shipping used nuclear fuel. The Portland and Western Railroad is a Class II railroad whose track is expected to be capable of accommodating shipments of HI-STAR 100 casks from the Trojan site. The Trojan site also has a barge slip which was used when the reactor pressure vessel, pressurizer, and steam generators were shipped by barge on the Columbia River to the US Ecology low-level radioactive waste disposal facility near Richland, Washington. It is likely the barge slip could also be used by barges for shipping used nuclear fuel transportation casks. 


\subsubsection{La Crosse}

Rail access to the La Crosse site is provided by the BNSF Railroad that is east of the La Crosse ISFSI. At present, La Crosse does not have an active onsite rail spur. However, the onsite rail spur could be rebuilt, and the BNSF Railroad has a siding on the north end of the site that could be extended. ${ }^{13}$

Onsite barge access is available about 0.2 miles north of the La Crosse reactor site. The barge facility is routinely used for the removal of covers from coal barges using a portable crane. Barges that deliver coal to the site are then secured to piers parallel to the river shore where their cargo is off-loaded to the shore via overhead conveyors. The ability of the onsite barge facility to accommodate used nuclear fuel transportation casks would need to be determined.

Assuming that the onsite rail spur into the La Crosse site is maintained or refurbished as may be needed, it is unlikely that heavy haul trucks would be used to remove transportation casks containing used nuclear fuel or GTCC low-level radioactive waste from the site.

\subsubsection{Zion}

At the Zion site, a rail spur connects to the Union Pacific Railroad mainline that runs between Milwaukee, Wisconsin, and Chicago, Illinois. The Union Pacific Railroad is a Class I railroad that is expected to have the capability to move shipments of used nuclear fuel in NAC MAGNATRAN transportation casks. Rail service to the Zion site is being reestablished and lowlevel radioactive waste rail shipments from the Zion site to Clive, Utah are expected to begin in November or December 2012 (ZionSolutions 2012).

The Zion barge facility used during plant construction was abandoned and the land upon which it was located was donated to the Illinois Beach State Park. If barge service were reestablished at the Zion site, casks containing used nuclear fuel could be shipped from the site by barge.

\footnotetext{
${ }^{13}$ Ross SB. 2012. Email message from DG Egge (Plant Manager, LACBWR, Dairyland Power Cooperative) to SB Ross
} (Pacific Northwest National Laboratory), “Re: La Crosse Information,” October 7, 2012. 
Nuclear Fuels Storage and Transportation Planning Project A Preliminary Evaluation of Removing Used Nuclear Fuel From Nine Shutdown Sites 


\section{ACTIONS NECESSARY TO REMOVE USED NUCLEAR FUEL FROM SHUTDOWN SITES}

The tasks that would need to be undertaken to remove used nuclear fuel and GTCC low-level radioactive waste from the shutdown sites may be divided into two phases: 1) programmatic activities to prepare for transport operations from a shutdown site, and 2) operational activities to prepare, accept, and transport from a shutdown site. Table 5-1 provides a high-level summary of the tasks that would take place during these two phases. The tasks are described in the following sections. In the descriptions of these tasks, the terms accept or acceptance are sometimes used. In this report, these terms mean that a shipment has been properly prepared for transport. In addition, it should be noted that DOE has not made any decisions regarding the priority or preference for removing used nuclear fuel from shutdown sites.

Table 5-1. Activities to Prepare for and Remove Used Nuclear Fuel from Shutdown Sites

\begin{tabular}{|c|c|}
\hline Task & Task Activity Description \\
\hline \multicolumn{2}{|c|}{ Programmatic Activities to Prepare for Transport Operations from a Shutdown Site } \\
\hline $\begin{array}{l}\text { 1. Assemble Project } \\
\text { Organization }\end{array}$ & $\begin{array}{l}\text { Assemble management teams, identify shutdown site existing infrastructure, constraints, } \\
\text { and transportation resource needs and develop interface procedures. }\end{array}$ \\
\hline $\begin{array}{l}\text { 2. Acquire Casks, Rail } \\
\text { Cars, Ancillary } \\
\text { Equipment, and } \\
\text { Transport Services }\end{array}$ & $\begin{array}{l}\text { Develop specifications, solicit bids, issue contracts and initiate preparations for shipping } \\
\text { campaigns. Includes procurement of transportation casks and revisions to certificates of } \\
\text { compliance as may be needed, procurement of AAR Standard S-2043 rail cars, and } \\
\text { procurement of offsite transportation services. }\end{array}$ \\
\hline $\begin{array}{l}\text { 3. Conduct Preliminary } \\
\text { Logistics Analysis and } \\
\text { Planning }\end{array}$ & Determine fleet size, transport requirements, and modes of transport for shutdown site. \\
\hline $\begin{array}{l}\text { 4. Coordinate with } \\
\text { Stakeholders }\end{array}$ & $\begin{array}{l}\text { Assess and select routes and modes of transport and to support training of transportation } \\
\text { emergency response personnel. }\end{array}$ \\
\hline $\begin{array}{l}\text { 5. Develop Campaign } \\
\text { Plans }\end{array}$ & $\begin{array}{l}\text { Develop plans, policies, and procedures for at-site operational interfaces, support } \\
\text { operations, and in-transit security operations. }\end{array}$ \\
\hline \multicolumn{2}{|c|}{ Operational Activities to Prepare, Accept, and Transport from a Shutdown Site } \\
\hline $\begin{array}{l}\text { 6. Conduct Readiness } \\
\text { Activities }\end{array}$ & $\begin{array}{l}\text { Assemble and train at-site operations interface team and shutdown site workers. Includes } \\
\text { readiness reviews, table-top exercises and dry-run operations. }\end{array}$ \\
\hline $\begin{array}{l}\text { 7. Load for Offsite } \\
\text { Transport }\end{array}$ & Load and prepare loaded casks and place on transporters for offsite transportation. \\
\hline $\begin{array}{l}\text { 8. Accept for Offsite } \\
\text { Transport }\end{array}$ & Accept loaded casks on transporters for offsite transportation. \\
\hline 9. Transport & Ship shutdown site casks. \\
\hline
\end{tabular}

\subsection{Programmatic Activities to Prepare for Transport Operations from a Shutdown Site}

Activities that would need to be taken to prepare for transport operations at each of the nine shutdown sites and to ship the fuel to an offsite destination can be rolled up to the first five major groups of activities listed in Table 5-1. 


\subsubsection{Task 1 - Assemble Project Organization}

For the initial project organization, it would be necessary to assemble the personnel and supporting resources to begin planning, collecting information, conducting analyses, developing interface procedures, and undertaking other preparations to remove used nuclear fuel and GTCC low-level radioactive waste from the shutdown sites. These activities would establish organizations, policies, plans, and procedures necessary for the project to begin the work necessary to acquire and qualify the physical and personnel resources that would be needed to make the shipments of used nuclear fuel and GTCC low-level radioactive waste from the nine shutdown sites.

Among the key activities would be to develop and implement the quality assurance plan for

- acquisitions of transportation casks and safety-related components

- selection and training of management and operations personnel

- used nuclear fuel transportation interface operations

- transportation cask maintenance and support operations.

At a minimum, the quality assurance plan would comply with the requirements of 10 CFR 71, Subpart H.

Another key activity would be to establish interface procedures for each of the nine shutdown sites. Areas addressed in these interface procedures could include

- description of the transportation casks, associated equipment, and transportation vehicles/conveyances that would be delivered to the shutdown site

- delivery of transportation casks and associated ancillary equipment to the shutdown site

- description of the assistance available to train and advise site personnel regarding the operation and use of transportation casks and ancillary equipment at the shutdown site

- descriptions of the used nuclear fuel and GTCC low-level radioactive waste that would be loaded into the transportation casks at the shutdown site

- descriptions of the canisters that contain the used nuclear fuel and GTCC low-level radioactive waste that, with their contents, would be loaded into transportation casks by the shutdown site operations organization.

During this stage, it would also be necessary to establish organizations that would be responsible for site preparations, staffing, and acquisitions necessary to receive, load, and return loaded casks for offsite shipments. In general, it would be necessary to initially determine the needs of each individual site to make it ready for a shipping campaign and to establish organizational elements that are essential for coordinating and assembling the resources that would be needed to provide transportation casks and make shipments. Generally, activities to prepare the shutdown sites to load transportation casks and deliver the casks for shipment should require less time than would 
be required to make acquisitions of equipment, personnel, and other resources for the shipping campaigns.

At some of the shutdown sites, it would be necessary to make improvements to roadways, rail spurs, or barge accesses for onsite movement of transportation casks and/or to deliver the transportation casks for offsite transport.

\subsubsection{Task 2 - Acquire Casks, Rail Cars, Ancillary Equipment, and Transport Services}

It would be necessary to acquire a fleet of transportation casks, ancillary equipment and rail cars to conduct the shipping campaigns from the shutdown sites. In the acquisition of transportation casks from cask vendors, transportation certificates of compliance would be updated, as is necessary, to accommodate all used nuclear fuel to be shipped from the shutdown sites (including damaged fuel assemblies in fuel control dry shielded canisters in storage at the Rancho Seco site) and GTCC low-level radioactive waste that is stored in canisters at the Humboldt Bay, Big Rock Point, and Rancho Seco sites.

Technical specifications would need to be developed for each kind of transportation cask and for major separable components (e.g., impact limiters) as well as the cask's associated ancillary equipment and consumables. There would be a minimum of six procurement specifications for the six kinds of transportation casks, components, ancillary equipment, and consumables that would need to be procured.

In addition, specifications would be developed for railcars that would be needed to transport the transportation casks. Three kinds of railcars would need to be procured: railcars for transportation casks, buffer cars, and escort cars. Based on previous transportation planning conducted for used nuclear fuel shipments (DOE 2009), all three types of railcars would be specially designed cars that would need to be tested to verify their conformance to AAR Standard S-2043 (AAR 2008). Testing services would need to be procured for the railcars.

Because the transportation casks that would be used to transport used nuclear fuel and GTCC low-level radioactive waste from the nine shutdown sites would be similar in size and weight, it is possible that only one design for a cask railcar would be needed. It may also be possible to use, with only minor modifications, the design and specification developed and qualified by the U.S. Navy for railcars it is procuring for the shipment of M-290 transportation casks for naval used nuclear fuel. In addition, it may be possible to adopt the design and specification being developed by the U.S. Navy for escort railcars. A buffer railcar design may be jointly developed with the Navy.

To obtain AAR's non-provisional certification that the three types of railcars would perform in accordance with the provisions of the AAR Standard, it would be necessary to conduct train tests in which all cars in the train comply with the car standards of AAR Standard S-2043 and for which the cask cars have representative loads. 
Last, it would be necessary to procure transportation services for the offsite transportation of casks that contain used nuclear fuel and GTCC low-level radioactive waste and for unloaded casks that would be returned to shutdown sites for loading. These services will include long-haul transport services provided by Class I (Mainline), Class II (Regional), and Class III (Short Line) railroads as well as services provided by operators of heavy haul trucks, barge and port operators, and heavy lift equipment operators for intermodal transfer operations. The services of private security companies for physical security services in all stages of transit from departure from the shutdown sites to delivery to a destination site may also be procured. In-transit security personnel may also be accompanied by health physics support personnel if it is determined that this is required.

\subsubsection{Task 3 - Conduct Preliminary Logistics Analysis and Planning}

In this task, the information needed to estimate the amount of time that would be required to load and ship casks containing used nuclear fuel and GTCC low-level radioactive waste from each of the nine shutdown sites would be collected. It would also be necessary to estimate the time that would be required at the destination facility to receive, unload, inspect, and maintain, and return casks for their next shipments.

The time required for loading and preparing a cask for transportation is expected to be different for each of the nine shutdown sites. The differences would arise because of differences in the resources that the sites may deploy and differences in the transportation casks that would be used. Examples of such differences include the number of transfer casks that could be used to transfer canisters from storage modules to transportation casks that are available at a site, and whether it would be necessary to move the loaded transportation casks from the loading station to the transport vehicle, e.g., onsite transfer onto a barge such as may occur at the Connecticut Yankee site versus directly onto a rail car, which would be expected to occur at the Maine Yankee, Zion, La Crosse, Rancho Seco, and Trojan sites. In addition, at the Humboldt Bay site the canisters that contain used nuclear fuel and GTCC low-level radioactive waste are stored in HI-STAR HB transportable overpacks, thereby making transfers from storage modules to transportation casks unnecessary. It would still be necessary to conduct inspections and tests to verify that the HI-STAR HB casks comply with the requirements of their certificates of compliance before shipments can be made. In addition, it would be necessary to install impact limiters on the HI-STAR HB casks, place the casks onto transport skids, and load the assembled transport packages onto a transport vehicle at the site.

The amount of time that would be required to transport loaded and unloaded casks from and to the shutdown sites, and to and from a destination site would also vary among the nine shutdown sites. Some of the differences would be because the travel distances to a destination site from the shutdown sites would be different. Other differences among the nine shutdown sites could have a greater influence on time in transit for shipments than the distance from the destination site. For example, if it is necessary to use heavy haul trucks to transport HI-STAR HB casks 160 to 260 miles from the Humboldt Bay site to a nearby railhead and then transfer the casks to railcars to complete the transport to a destination site, the time in transit would be significantly different than that for shipments from the Trojan or Rancho Seco sites in the western states region of the 
United States. The Trojan and Rancho Seco sites have direct access to a railroad and thus would be able to load casks onto railcars at the sites.

Conversely, shipments from the Humboldt Bay site would be one-way movements with no return of the transportation casks to the site for reloading whereas shipments of transportation casks from all eight of the remaining sites would require returns of unloaded transportation casks for reloading. At the Connecticut Yankee, Yankee Rowe, and Big Rock Point sites outbound loaded shipments would involve heavy haul truck or barge shipments to nearby railheads and transfers of casks from the heavy haul trucks, or possibly from barges, to railcars. Returning shipments of unloaded casks would require the reverse of the sequence for the outbound shipments. Although unlikely, barges could also be used to ship transportation casks to nearby railheads or ports from the Maine Yankee, La Crosse, and Trojan sites.

The above factors that would affect the time required to make shipments would also affect the transportation resource requirements and the resource requirements at the shutdown sites and the durations of activities to remove used nuclear fuel and GTCC low-level radioactive waste from each of the sites and collectively from all nine of the shutdown sites. These factors along with the funding resources would be analyzed to assess the efficacy of alternative orders for shipments to be made from the shutdown sites and the numbers of each type of transportation cask (and components) and the number of cask cars, buffer cars, and escort cars to procure for each alternative set of assumptions. This information would be used to inform managers to support decisions regarding modes of transport, acquisition decisions, staffing decisions, and allocations of resources.

\subsubsection{Task 4 - Coordinate with Stakeholders}

Coordination with stakeholders to assess and select routes and modes of transport and to support training of transportation emergency response personnel of states and tribes would be an essential activity. It would build on similar coordination efforts currently supported by the DOE Office of Environmental Management through the National Transportation Stakeholder Forum and through support of state regional groups: the Southern States Energy Board, the Western Interstate Energy Board/Western Governors’ Association, Midwestern Office of the Council of State Governments, and the Eastern Regional Conference of the Council of State Governments.

A key activity would be to develop and implement policy and procedures to provide technical and funding assistance to states and tribes that would be affected by the transport of used nuclear fuel through and near to their jurisdictions. The funding and technical support would be similar to that described in Section 180(c) of the Nuclear Waste Policy Act, as amended (42 U.S.C. 10101 et seq.) and would be to assist the states and tribes in training of state, tribal, and local officials who would be responsible for helping to ensure the safe transport of used nuclear fuel through their jurisdictions as well as emergency response to transportation accidents that may involve the shipments of used nuclear fuel from the shutdown sites.

In addition to developing and implementing procedures for technical and funding support to states and tribes for safe transportation and emergency response for transportation accidents, the 
transportation operations organization would work collectively with the affected states and the tribes to determine the modes of transportation that could be used to move used nuclear fuel from the nine shutdown sites as well as the routes that would be used. This would be a collaborative effort in which the transportation operations organization, transportation carriers, and the states and tribes would identify and weigh factors that would influence the selections to be made. Achievement of consensus among the involved parties regarding the modes and routes to be used for the shipments, as well as procedures to be implemented to ensure and provide confidence that the shipments would be made safely, would be the objective of this activity.

\subsubsection{Task 5 - Develop Campaign Plans}

As activities progress to procure resources needed to conduct shipping campaigns from the shutdown sites, it would be necessary to plan for and assemble staff who would conduct shipment operations. This planning effort would include determining the structure and organization of the work to be performed to conduct shipment operations, acquiring and training the staff who would conduct operations, developing operational procedures, and establishing the necessary supporting organizational infrastructure.

The major elements of the work structure for the transport operations activities would include transportation fleet management, shipping campaign management, and in-transit operations management. Sub-elements within these three management elements would include:

- transportation cask, ancillary equipment, and railcar maintenance and servicing

- campaign kit assembly and distribution ${ }^{14}$

- scheduling and expediting of shipping campaigns including shipments (loaded and unloaded casks), equipment, field personnel, and in-transit security and safety escort personnel

- coordination of shipment notifications, in-transit tracking, in-transit physical security, and emergency response operations

- field services including technical support to shutdown site operations for loading and preparing casks for shipment.

In addition to training that would be conducted to prepare for operations, activities for the operations staff before the transport operations begin would include:

- developing operations procedure

- establishing operational interfaces with the operations organizations at each of the nine shutdown sites

\footnotetext{
${ }^{14}$ Campaign kits are collections of special tools and equipment that would be needed at shipping sites to load and prepare casks for transport and at intermodal transfer locations where casks would be transferred to and from rail cars from and to another mode of transportation.
} 
- establishing operational interfaces with officials of state, tribal, and local governments whose jurisdictions would be affected by transportation of used nuclear fuel from the nine shutdown sites

- establishing operational interfaces with transportation carriers and providers of special transportation services that may be needed

- $\quad$ establishing operational interfaces with the operator of the destination facility.

Establishing organizations (or elements matrixed from other organizations) that would support shipment operations activities would also be necessary. The support organizations would include: quality assurance, licensing and regulatory compliance (to ensure that certificates of compliance are current and encompass the used nuclear fuel that would be shipped), training, procurement, public information, and field engineering. Each of these supporting organizational elements would need to acquire its own staff and resources and develop its own policies, plans, and procedures that would be tailored to meet their unique needs.

\subsection{Operational Activities to Prepare, Accept, and Transport from a Shutdown Site}

The activities to prepare, accept, and transport used nuclear fuel from each of the nine shutdown sites are rolled up into the four major groups of activities listed in the second half of Table 5-1. These are expected to include table top exercises that would support training for shipments and dry run activities at shipping sites and at intermodal transfer locations. These readiness activities would be followed by loading of casks at the shutdown sites, acceptance of the casks loaded and prepared for transport, shipment of the casks to the destination facility, inspection and maintenance of casks following shipment, and return of unloaded casks to shipping sites.

\subsubsection{Task 6 - Conduct Readiness Activities}

Table-top exercises would involve the transportation operations organization and the shutdown site operations organization with applicable state, tribal, and local officials participating as observers. It is also anticipated that in-transit table-top exercises would involve participation by transportation planning and operations organizations and officials from affected states, tribes, and local governments. The table-top exercises would be in-office drills designed to identify gaps in planning, procedures, and training for the full sequence of operations that would be involved in making shipments of used nuclear fuel and GTCC low-level radioactive waste from the shutdown sites to a destination facility. These exercises would be developed jointly by the operations, training, and quality assurance organizations.

Following the table-top exercises, the transportation and shutdown site operations organizations would conduct dry-run operations to establish the operational basis for determining readiness to make shipments. The dry-run operations would not involve removal of canisters containing used nuclear fuel from storage systems but would involve the full sequence of operational steps. These steps would include handling, loading, and preparation of casks for shipment; loading of 
the casks onto transport vehicles; and intermodal transfers of casks from heavy haul trucks or barges to rail cars and the reverse operation.

Readiness reviews would be conducted jointly by the transportation operations organization, the shutdown site operations organization, and transportation service operators to review the results of table-top and dry-run activities and to verify that open issues identified in these exercises have been appropriately resolved. Readiness reviews would also be conducted with state, tribal, and local officials to ensure that there are no outstanding issues that would need to be addressed to ensure effectiveness of emergency response and in-transit security operations that the transited jurisdictions may provide.

\subsubsection{Task 7 - Load for Offsite Transport}

Shutdown site operations organizations would remove the transportable dry storage canisters containing used nuclear fuel or GTCC low-level radioactive waste from onsite storage systems, load the canisters into transportation casks, prepare the loaded casks for shipment, and load the prepared casks onto transport vehicles. Unloaded casks would be delivered to each of the shutdown sites either on railcars, heavy haul trucks, or barges. Except for the Humboldt Bay site, shutdown site operations organization would receive casks at its site, prepare the casks to be loaded and verify the casks are suitable for loading with canisters that contain the site's used nuclear fuel. Each shutdown site operations organization would be registered with the NRC as a user of the transportation cask that would be loaded at the site. The shutdown site operations organization would use equipment designed by the vendor of the storage system and transportation cask and follow onsite procedures to transfer canisters containing used nuclear fuel or GTCC low-level radioactive waste from its onsite storage system into the transportation cask body. The shutdown site operations organization would then prepare the transportation cask for shipment including assembly of all components and conduct of tests to verify proper assembly for shipment specified by the cask's certificate of compliance. Last, the shutdown site operations organization would place the transportation cask on a shipping skid/cradle, load the cask-on-cradle unit onto the transport vehicle, and provide the documentation required to verify that the shipment has been properly packaged for offsite transportation. The time required to complete the sequence of operations from receipt of an unloaded cask through to delivery of the cask for offsite transportation was assumed to average up to one calendar week.

Used nuclear fuel at the Humboldt Bay site is stored in storage/transport canisters in HI-STAR HB cask bodies. The HI-STAR HB cask, when impact limiters are attached, is certified by NRC to transport the used nuclear fuel from the Humboldt Bay site. Thus, the site's operator would not have to transfer canisters from a storage system to a transportation cask. Nonetheless, the shutdown site operations organization would be required to remove the alreadyloaded HI-STAR HB casks from their sub-grade storage locations, complete assembly of the casks for transport including installing impact limiters, conduct pre-shipment tests that are specified in the cask's certificate of compliance, load the casks onto transport vehicles, and provide the documentation required to verify that the shipment of used nuclear fuel has been properly packaged for offsite transportation. 


\subsubsection{Task 8 - Accept for Offsite Transportation}

At each of the shutdown sites and for each cask shipped from the sites, the transportation operations organization would accept loaded casks that have been prepared for shipment and placed onto transport vehicles. The transportation operations organization would also take possession of the used nuclear fuel or GTCC low-level radioactive waste that is contained in the casks at the same time it accepts the shipment. For each such shipment, preparation would be made in advance to ensure that the contents of the shipment are verified and that the requirements of the transportation certificate of compliance have been met. The transportation operations organization field operations staff would inspect documentation for each shipment that has been prepared and provided by the owner of the shutdown site and, as appropriate, conduct physical inspections of the loaded transportation cask on its transport vehicle.

\subsubsection{Task 9 - Transport}

The complexity of offsite transportation of casks containing used nuclear fuel or GTCC low-level radioactive waste from the shutdown sites would vary among the sites. Shipment operations from sites that would require use of heavy haul trucks or barges to move casks to nearby railheads would be significantly more complex than those from sites where the casks could be directly loaded onto railcars for offsite shipment. In addition, sites where there is a practical limit of one or two casks that can be placed on railcars for shipment in a single train would require a greater application of resources than would be the case for sites that have onsite rail spurs that can accommodated many rail cars and connect to a railroad that can accommodate trains hauling five or more of the heavy cask cars.

Shipment operations would involve advance scheduling and notification of state and tribal governments; coordination among the transportation physical security force and state, tribal, and local security officials; coordination between transportation companies and the transportation operations organization for shipments that involve intermodal operations; and cross-country coordination among the rail carriers and the transportation operations organization to ensure that shipment schedules are known and maintained. The transportation operations organization would use satellite tracking to monitor the progress of each shipment containing used nuclear fuel or GTCC low-level radioactive waste en route. The transportation operations organization may also use satellite tracking along with expediting services to expedite return shipments of unloaded casks to shutdown sites.

In-transit operations for shipments of used nuclear fuel and GTCC low-level radioactive waste would principally involve real-time tracking of shipment locations and deployment of physical security personnel, and possibly radiological safety technicians, who would observe shipments from the escort railcars that would be included in each used nuclear fuel rail shipment.

The transportation operations organization would maintain an Emergency Operations Center that would maintain readiness to direct resources to respond to any in-transportation event that may occur during shipment of used nuclear fuel or GTCC low-level radioactive waste from the 
shutdown sites. The Emergency Operations Center would coordinate U.S. Government response efforts with those of state, tribal, and local officials in a jurisdiction that may be involved.

A typical shipment of a loaded casks containing used nuclear fuel or GTCC low-level radioactive waste would require 1 to 2 weeks of transit time to complete. Shipments over distances of 500 to 1,000 miles and where rail cars are loaded at shipping sites would generally be completed in about 1 week. Shipments over distances that exceed 1,000 miles and that require use of intermodal transportation would generally require about 2 weeks. Based on the experience of the U.S. Navy, shipments of unloaded casks returning to a site for reloading, if not expedited, can require up to a month.

\section{$5.3 \quad$ Results}

In this preliminary evaluation, representative time sequences of activities listed in Table 5-1 and their durations were first developed for four scenarios involving a single site that was assumed to be served by a railroad. The four scenarios are described as follows.

In the first scenario used nuclear fuel was removed from one shutdown site. For the purposes of this report, the shutdown site was assumed to be Maine Yankee, where 60 canisters of used nuclear fuel and 4 canisters of GTCC low-level radioactive waste are stored. The Maine Yankee site was used in constructing this scenario only for the purposes of analysis. DOE has not made any decisions regarding the priority or preference for removing used nuclear fuel from shutdown sites. The time sequence presented in this scenario provides an initial estimate of the duration for key activities and the total duration for removing used nuclear fuel and GTCC low-level radioactive waste from a single site that is served by a railroad. For the purposes of the scenario, the analysis assumed that DOE would procure five transportation casks that would be dedicated to shipping used nuclear fuel and GTCC low-level radioactive waste from the site. The time durations used for the scenario were based on conservative estimates of the time durations for tasks. Figure 5-1 illustrates the time sequence of activities and their estimated durations for this scenario.

The second scenario was similar to the first scenario, but optimistic estimates of the time durations for tasks were used. Figure 5-2 illustrates the time sequence of activities and their estimated durations for this scenario.

The third scenario that assumed that DOE would procure 10 casks that would be dedicated to shipping used nuclear fuel and GTCC low-level radioactive waste from the site, and that would be operated in two, five-cask trains. The time durations used for the scenario were based on conservative estimates of the time durations for tasks. The fourth scenario was similar to the third scenario, but where optimistic estimates of the time durations for tasks were used.

Figure 5-3 presents the total time durations for the four scenarios for comparison. The estimated time from the start of the project to the completion of the last shipment of used nuclear fuel and GTCC low-level radioactive waste from this single site was shown to range from 6.2 years to 11.2 years. The estimated durations were most affected by the time required to procure casks, 
components, and campaign kits, and the time required to procure railcars that meet AAR Standard S-2043 (AAR 2008). For procuring casks, components, and campaign kits, the estimated time durations ranged from 36 to 48 months. For procuring railcars that meet AAR Standard S-2043, the estimated time durations ranged from 36 to 66 months.

As illustrated in Figures 5-1 and 5-2 the tasks to procure casks and railcars were assumed to take place in parallel. The Humboldt Bay site does not require the procurement of casks, although procurement of impact limiters and S-2043 compliant railcars would be required. Because the amount of time required to obtain AAR approved railcars would be independent of the site from which shipments were made, and because obtaining AAR-approved railcars is a critical path activity, the total time required for a project to remove used nuclear fuel and GTCC low-level radioactive waste from Humboldt Bay would not be significantly shorter than that for the single site example and would range from about 5 to 6 years. 


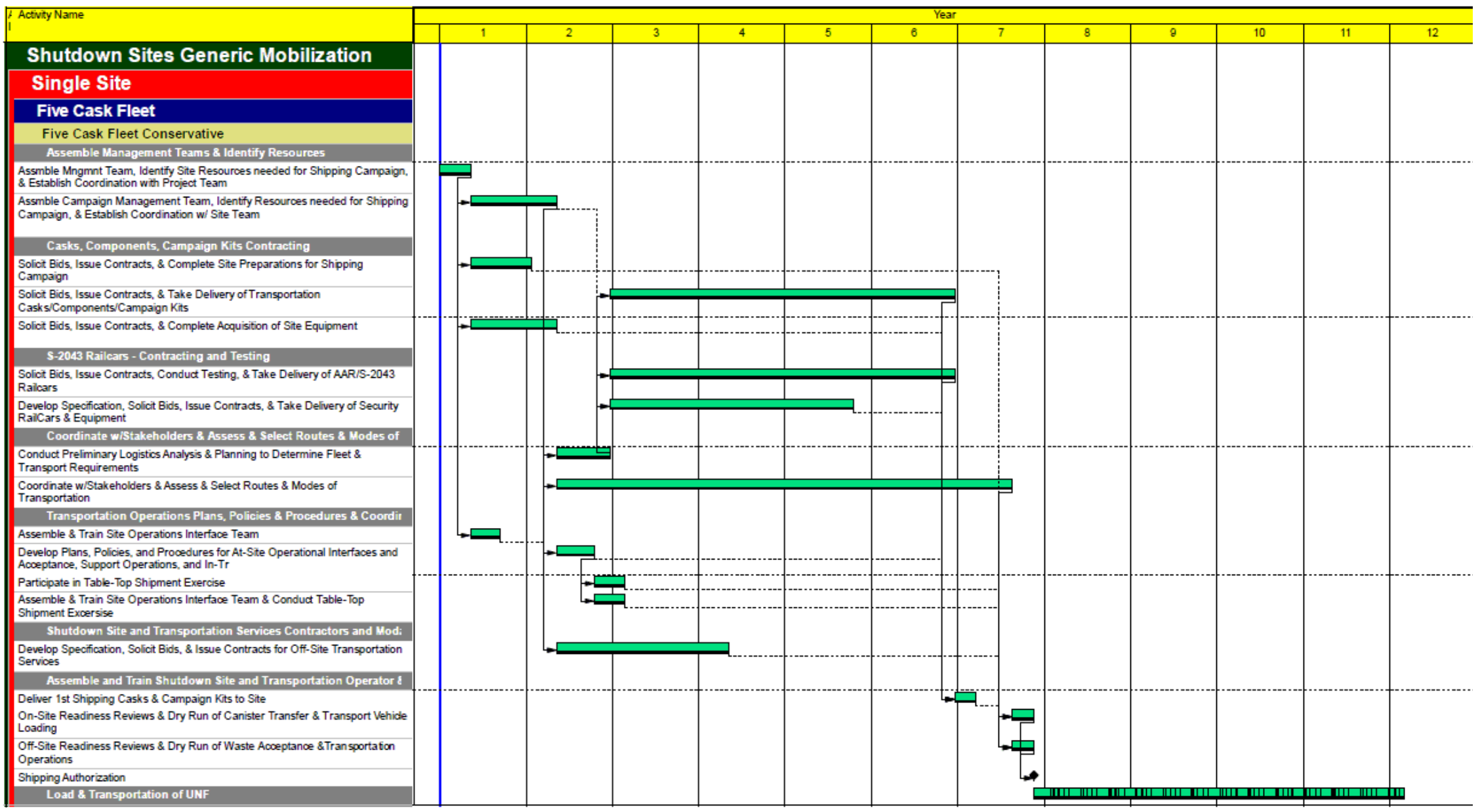

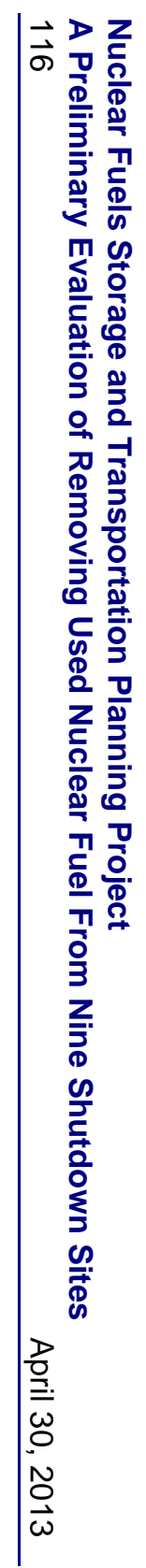

Figure 5-1. Time Sequences of Activities and Estimated Durations to Prepare for and Remove Used Nuclear Fuel from a Single Shutdown Site Based on Five Casks and Conservative Task Durations 


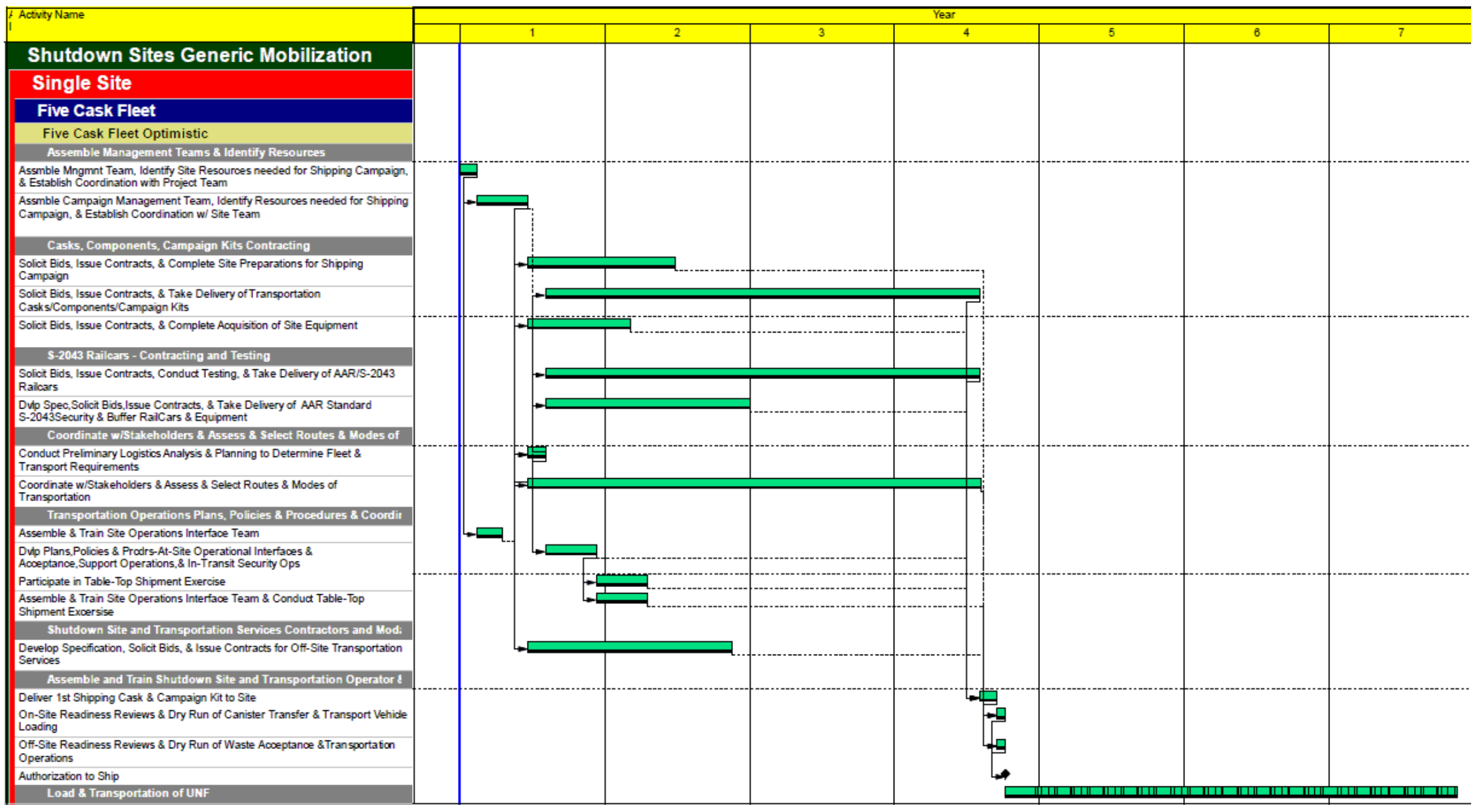

Figure 5-2. Time Sequences of Activities and Estimated Durations to Prepare for and Remove Used Nuclear Fuel from a Single Shutdown Site Based on Five Casks and Optimistic Task Durations 

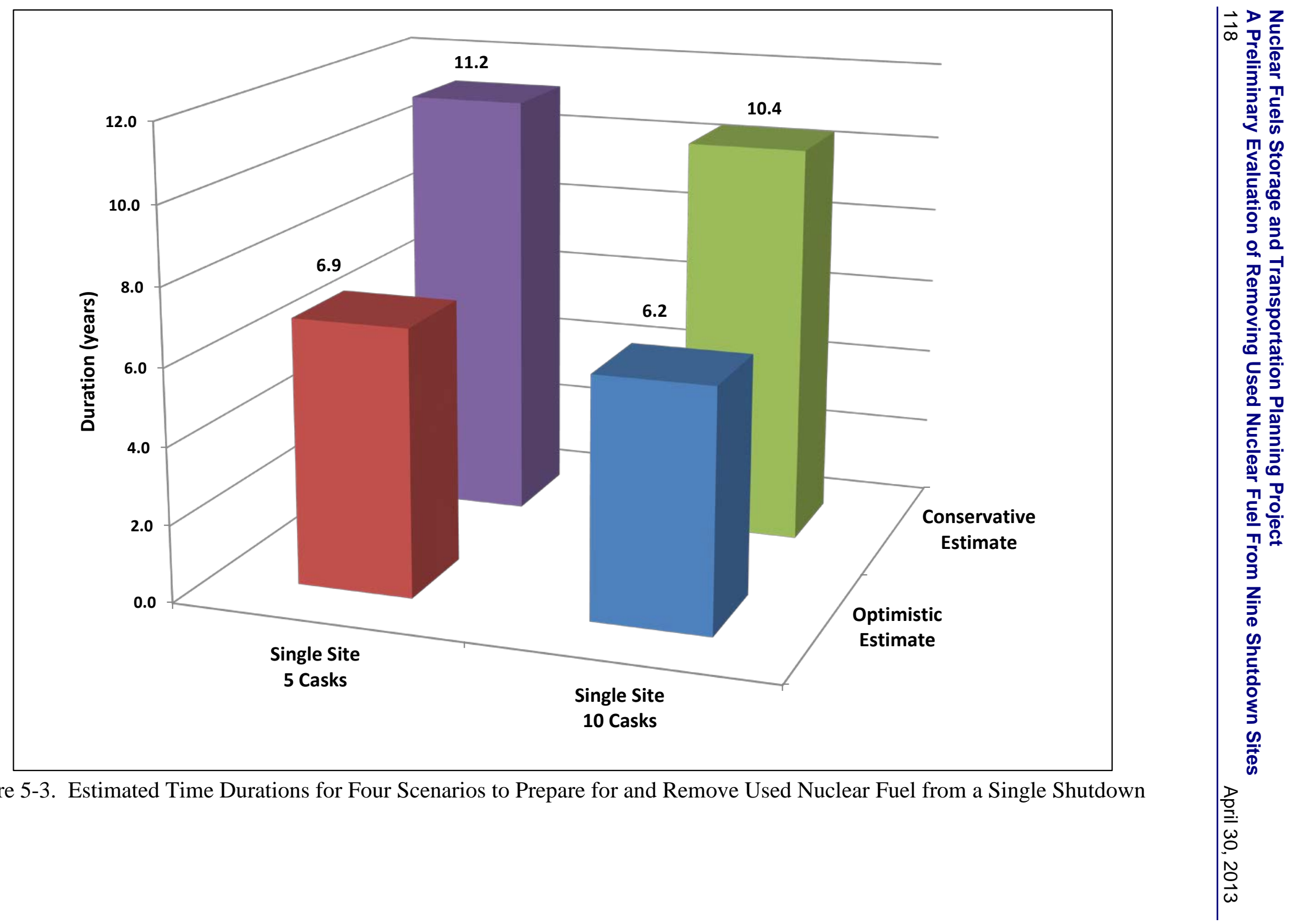

Figure 5-3. Estimated Time Durations for Four Scenarios to Prepare for and Remove Used Nuclear Fuel from a Single Shutdown Site 
Representative time sequences of activities and their durations were then developed for four scenarios involving multiple sites. The sites selected for this analysis were the Maine Yankee, Yankee Rowe, and Connecticut Yankee sites. The analysis assumed that the used nuclear fuel and GTCC low-level radioactive waste at the sites would be removed in coordinated campaigns. These sites were selected for this analysis because of their geographic proximity and because three different modes of transportation could be used in transporting the used nuclear fuel and GTCC low-level radioactive waste from the sites: direct rail at Maine Yankee, heavy haul truck to rail at Yankee Rowe, and barge to rail at Connecticut Yankee. Maine Yankee, Yankee Rowe, and Connecticut Yankee were used in constructing this scenario only for the purposes of analysis. DOE has not made any decisions regarding the priority or preference for removing used nuclear fuel from shutdown sites. Four scenarios were evaluated, and are described as follows.

In the first scenario five NAC-UMS UTC casks would be used to remove the used nuclear fuel and GTCC low-level radioactive waste from the Maine Yankee site and four NAC-STC casks would be used to remove the used nuclear fuel and GTCC low-level radioactive waste from Yankee Rowe and Connecticut Yankee sites. For the Yankee Rowe and Connecticut Yankee sites, the analysis assumed that the shipping campaigns would be conducted so that shipments from one site would be completed before shipments from the second site would begin. Also, the analysis assumed that at the same time shipments were being made from the Yankee Rowe or Connecticut Yankee site that shipments would be ongoing from the Maine Yankee site. This scenario also used conservative estimates of the time durations for tasks. In this scenario, the five NAC-UMS UTC casks are assumed to be operated in single five-cask train at Maine Yankee and the four NAC-STC casks were assumed to be operated in two, two-cask trains at both Yankee Rowe and Connecticut Yankee. Figure 5-4 illustrates the time sequence of activities and their estimated durations for this scenario. The second scenario was similar to the first scenario but used optimistic estimates of the time durations for tasks. In this scenario, the five NAC-UMS UTC casks are assumed to be operated in single five-cask train at Maine Yankee and the four NAC-STC casks were assumed to be operated in two, two-cask trains at Yankee Rowe and a single four-cask train at Connecticut Yankee. Figure 5-5 illustrates the time sequence of activities and their estimated durations for this scenario.

In the third scenario, the analysis assumed that five NAC-UMS UTC casks would be used to remove the used nuclear fuel and GTCC low-level radioactive waste from the Maine Yankee site and two NAC-STC casks would be used to remove the used nuclear fuel and GTCC low-level radioactive waste from Yankee Rowe and Connecticut Yankee sites. This scenario used conservative estimates of the time durations for tasks. The fourth scenario was similar to the third scenario, but used optimistic estimates of the time durations for tasks.

Figure 5-6 presents the total time durations for the four scenarios so that they may be compared. The time required to remove the used nuclear fuel and GTCC low-level radioactive waste from the three sites ranged from 7.7 years to 16.8 years. The durations were most affected by the time required to load and transport the used nuclear fuel and GTCC low-level radioactive waste; procure casks, components, and campaign kits; and the time required to procure railcars that meet AAR Standard S-2043. 
Figure 5-7 shows the representative durations and sequence of activities to prepare for and remove all used nuclear fuel and GTCC low-level radioactive waste from the nine shutdown sites. The cumulative duration of 11.5 to 14.5 years shown in Figure 5-7 for the project to prepare for and remove all used nuclear fuel and GTCC low-level radioactive waste from the sites includes the schedule uncertainty associated with procurement of casks (4.5 to 5.5 years) and railcars (4 to 5 years) and coordination of shipping campaigns (7 to 10 years). 


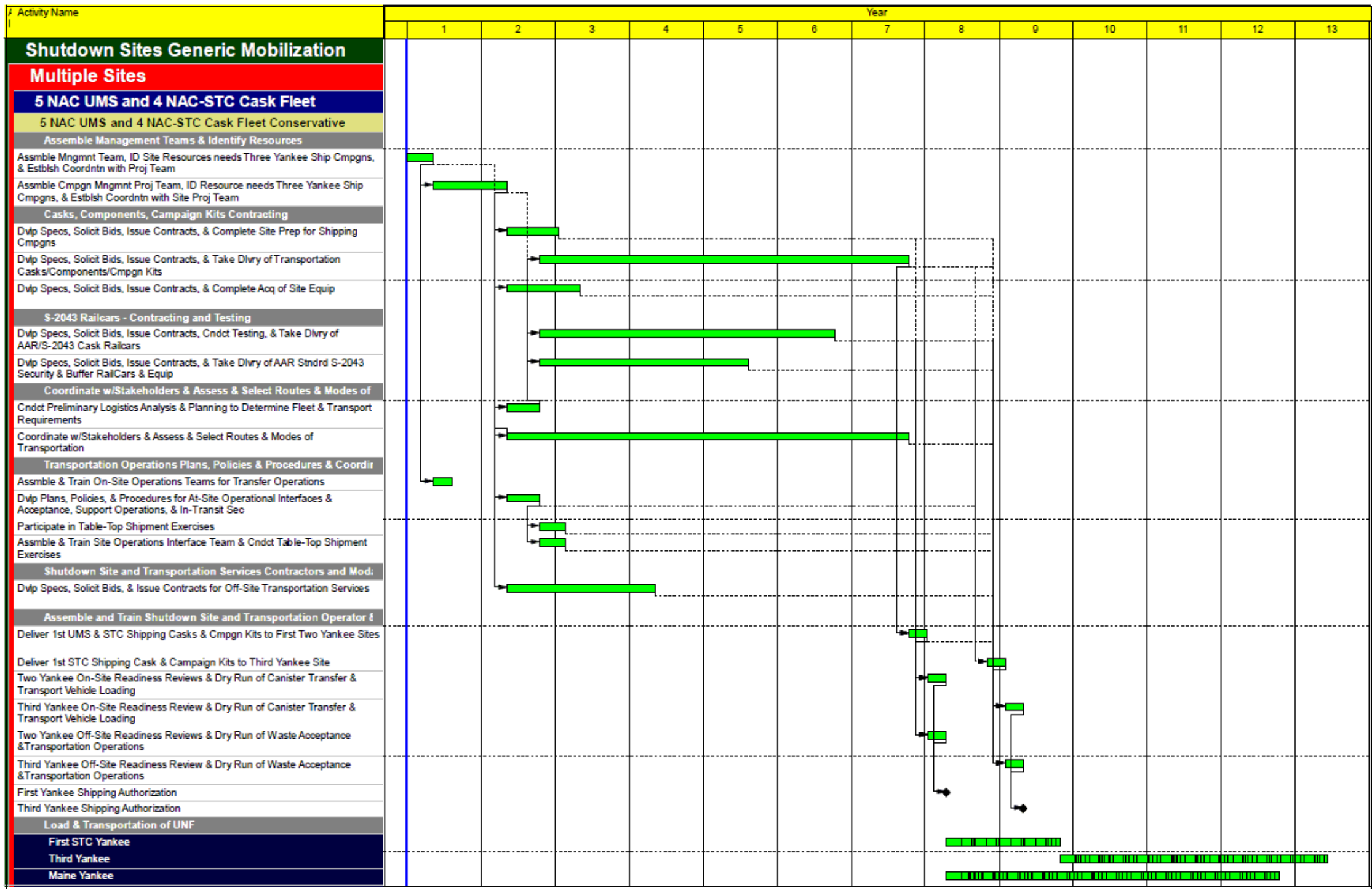

Figure 5-4. Time Sequences of Activities and Estimated Durations to Prepare for and Remove Used Nuclear Fuel from Multiple Shutdown Sites Based on Five NAC-UMS UTC Casks and Four NAC-STC Casks and Conservative Task Durations 


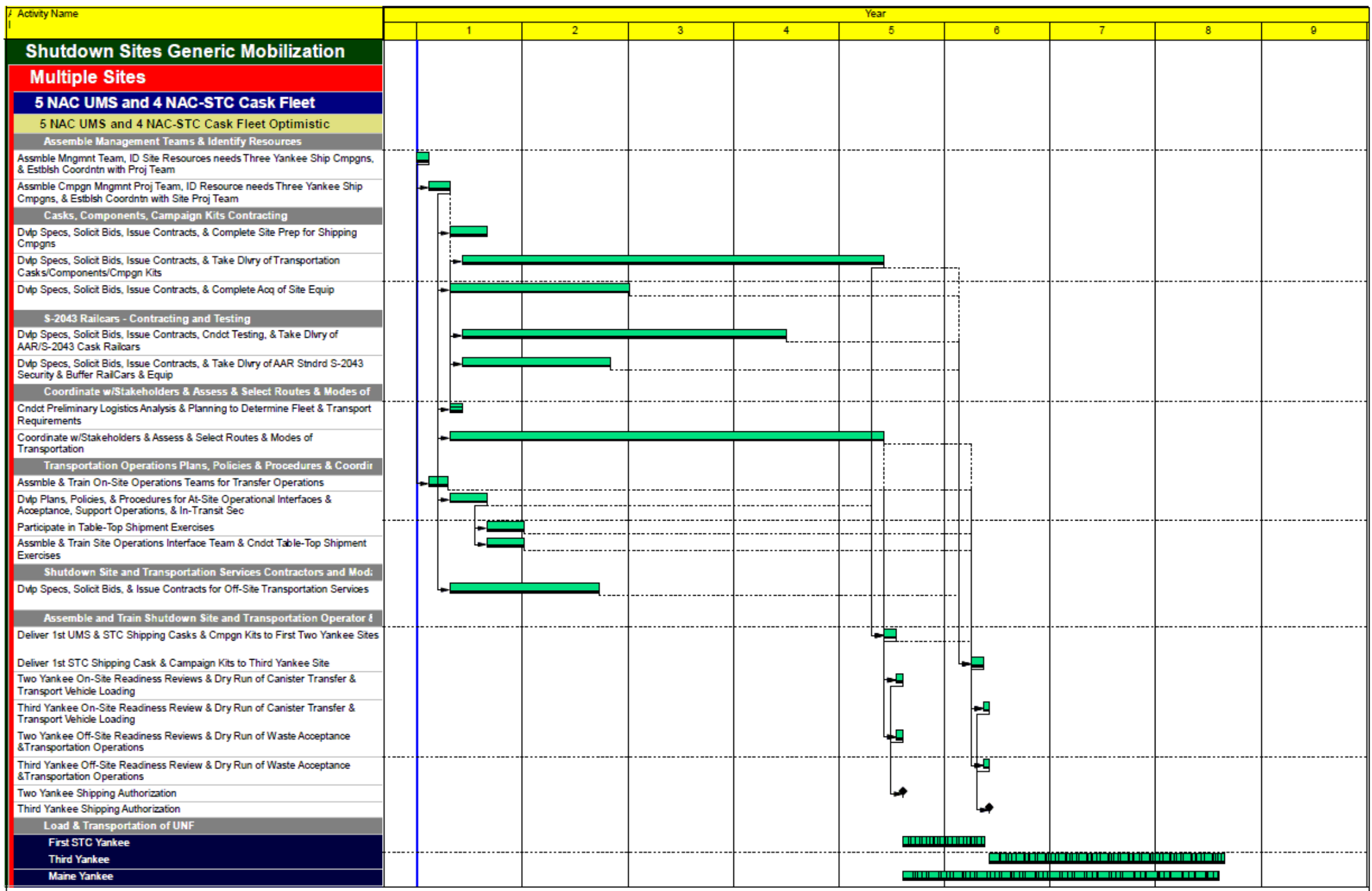

Figure 5-5. Time Sequences of Activities and Estimated Durations to Prepare for and Remove Used Nuclear Fuel from Multiple Shutdown Sites Based on Five NAC-UMS UTC Casks and Four NAC-STC Casks and Optimistic Task Durations 

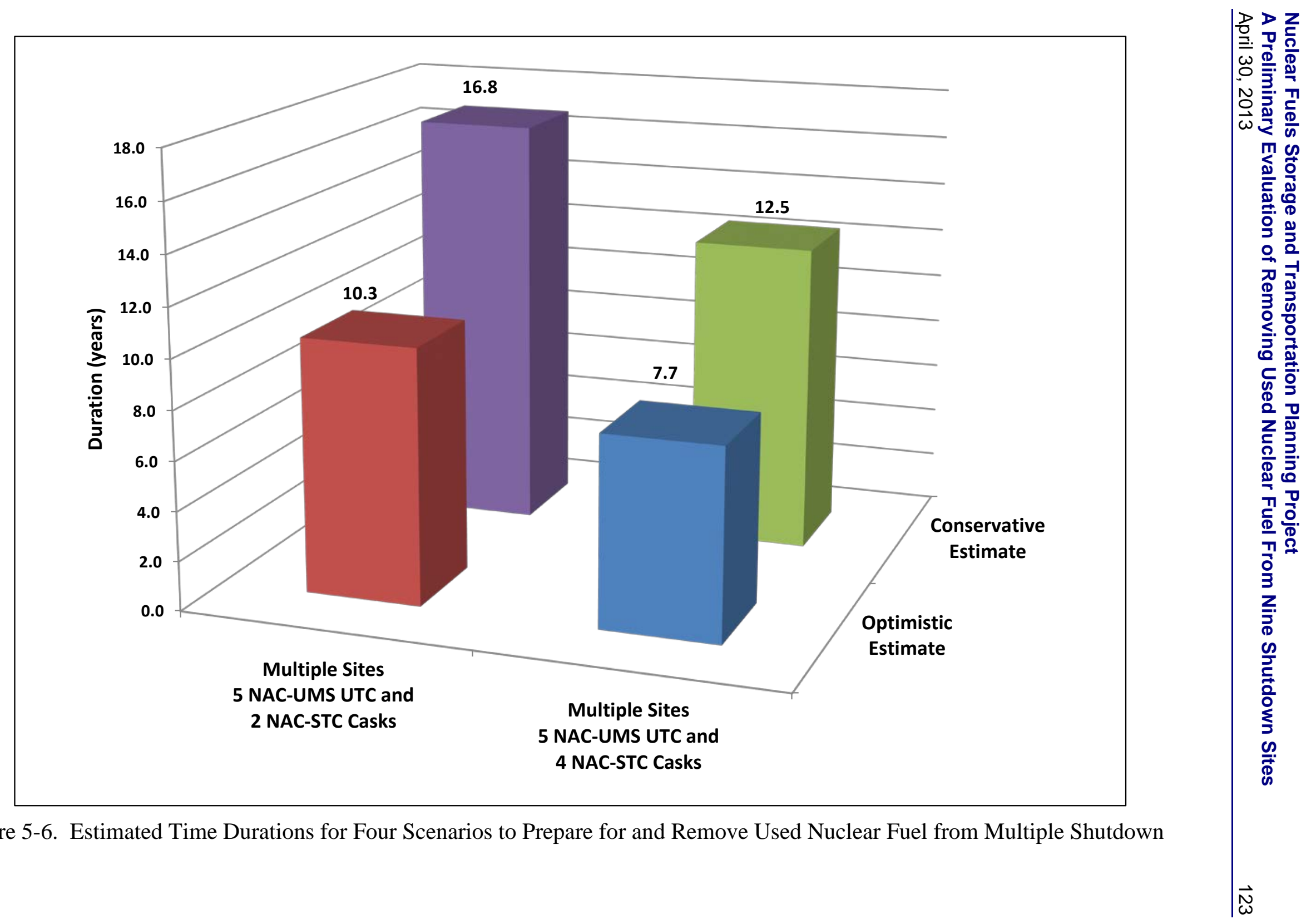

Figure 5-6. Estimated Time Durations for Four Scenarios to Prepare for and Remove Used Nuclear Fuel from Multiple Shutdown Sites 


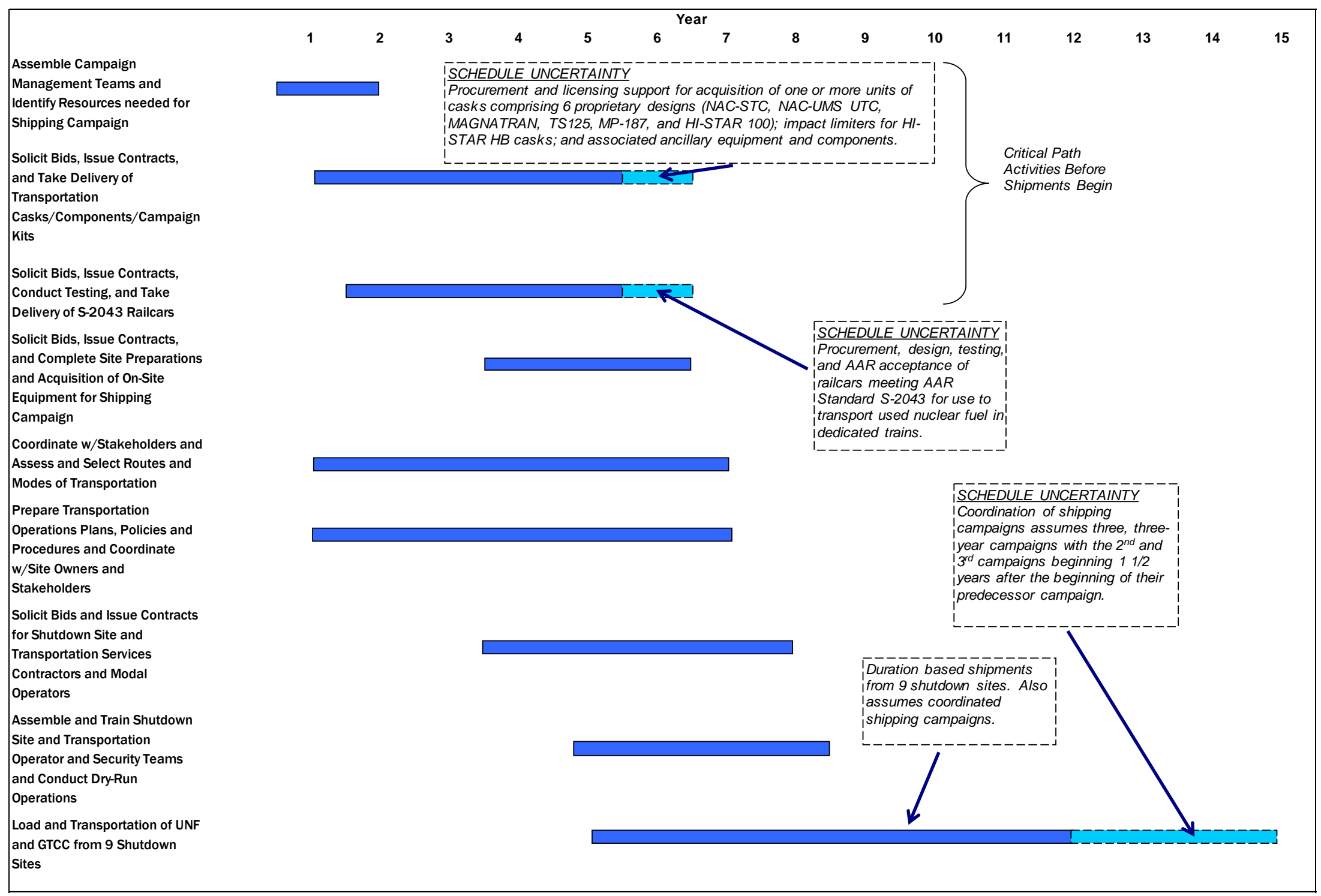

Figure 5-7. Estimated Durations of Key Activities to Prepare for and Remove Used Nuclear Fuel from Nine Shutdown Sites 
It is significant that the project activities that would precede shipments would require about the same amount of time for the case where shipments were assumed to be made from only one shutdown site as for the case where coordinated shipments were assumed to be made from three shutdown sites. However, the amount of effort and resources that would be required would differ for these two cases. For example, to ship from the three shutdown sites would require acquisition of two kinds of transportation casks (NAC-UMS UTC and NAC-STC casks) and the preparations and staffing to interact with the operators of three sites. There would be benefits from serving more than one site in that protocols, procedures, and operational interfaces would be similar among the sites. Also, the acquisition of additional railcars would not be expected to require substantially greater amount of effort by DOE after AAR certification was received on the railcar designs. Last, because the three sites were located in the same geographical region of the United States, interactions between DOE and state, tribal, and local authorities would be facilitated and could be coordinated to limit requirements for resources.

Similarly, the project activities that would precede shipments from all nine shutdown sites would require only a slightly greater amount of time than that that would be required the three shutdown sites. This assumes that project resources (personnel, funding, and functions such as procurement and quality assurance) would be adequate to support concurrent acquisitions of transportation casks and associated components that would include several units of each of the seven transportation casks that would be used at the shutdown sites-the NAC-STC, NAC-UMS UTC, MP187, TS-125, HI-STAR 100, HI-STAR HB, and MAGNATRAN; and to acquire and certify the fleet of cask, buffer, and escort rail cars that would be needed. It also assumes that there would be flexibility in making acquisitions such as limited constraints on procuring casks and associated components from non-domestic suppliers.

Assuming that project resources (including the number of cask, buffer, and escort rail cars; the staff needed to conduct and support shipping operations; and funding) are sufficient, shipment activities could be conducted concurrently from several of the shutdown sites. Based on discussions with managers at the Maine Yankee, Yankee Rowe, and Connecticut Yankee sites; assumptions regarding integrating the schedules for shipments from all nine shutdown sites; and assumptions regarding the project resources that would be made available, it is estimated that shipment operations to remove stranded used nuclear fuel from the shutdown sites could be completed in about 5 years. The relatively low rate of shipments (about 50 casks per year) would be principally the consequence of practical limits on the numbers of each type of cask that would be placed into service (assumed to be between two and five of each type of cask), the estimate that a cask would, on average, be used five or fewer times in a year, and the fact that interchangeable use of the six different transportation casks among the nine shutdown sites would be limited. 
Nuclear Fuels Storage and Transportation Planning Project

A Preliminary Evaluation of Removing Used Nuclear Fuel From Nine Shutdown Sites

126

April 30, 2013 


\section{CONCLUSIONS AND RECOMMENDATIONS}

In this report, a preliminary evaluation of removing used nuclear fuel from nine shutdown sites was conducted. The evaluation was divided in four components:

- characterization of the used nuclear fuel and GTCC low-level radioactive waste inventory at the shutdown sites

- an evaluation of the onsite transportation conditions at the shutdown sites

- $\quad$ an evaluation of the near-site transportation infrastructure and experience relevant to shipping transportation casks containing used nuclear fuel from the shutdown sites

- an evaluation of the actions necessary to prepare for and remove used nuclear fuel and GTCC low-level radioactive waste from the shutdown sites.

From the evaluations, time sequences of activities and time durations were developed for preparing for and removing the used nuclear fuel and GTCC low-level radioactive waste from a single shutdown site, from three shutdown sites located in proximity to each other, and for all nine shutdown sites.

Several issues were identified with the used nuclear fuel and GTCC low-level radioactive waste inventory at the shutdown sites. The most important of the issues was that there are six damaged fuel assemblies in five of the storage canisters at Rancho Seco that were not placed in failed fuel dry shielded canisters. Further evaluation would be needed to determine if the canisters containing this damaged fuel can be shipped in the MP187 transportation cask without repackaging. In addition, the lists of approved contents in the certificates of compliance for the TS125, HI-STAR HB, and MP187 transportation casks do not include GTCC low-level radioactive waste. Consequently, the GTCC low-level radioactive waste stored at the Big Rock Point, Humboldt Bay, and Rancho Seco sites would not be transportable without changes to the certificates of compliance for these transportation casks.

Based on the burnup data for the used nuclear fuel at the shutdown sites in the RW-859 database, there is very little high burnup used nuclear fuel in storage at the shutdown sites, only 90 assemblies at Maine Yankee and 36 assemblies at Zion. The Maine Yankee high burnup fuel is packaged in Maine Yankee Fuel Cans (i.e., damaged fuel cans). This option for transporting high burnup used nuclear fuel is allowed by the certificate of compliance for the NAC-UMS UTC transportation cask (Docket No. 71-9270), and eliminates the concern over its transportability. Ux Consulting (2012) states that for the MAGNATRAN transportation cask, all high burnup fuel will be canned in damaged fuel cans. This would also eliminate the concern over transportability of the high burnup fuel from Zion.

The used nuclear fuel at the shutdown sites was loaded into canisters and placed in ISFSIs as early as 2001. The initial storage licenses granted under 10 CFR 72 were for a period of 20 years, so renewals will need to occur starting in about 2018 to 2020 and it is likely that the NRC will have questions about the condition of the stored used nuclear fuel during the storage license 
renewal process. In addition, transportation cask certificates of compliance are for 5-year periods, so these certificates will also need to be renewed periodically. This will require a longterm commitment by the owners of the certificates of compliance to maintain these certificates.

Table 6-1 summarizes the options for transporting used nuclear fuel and GTCC low-level radioactive waste from the shutdown sites. The modes listed in Table 6-1 were based on the evaluations of onsite transportation conditions at the shutdown sites and the near-site transportation infrastructure and offsite transportation experience at the shutdown sites, particularly during large component removals during reactor decommissioning. An important observation regarding Table 6-1 is that all shutdown sites have at least one offsite transportation option for removing their used nuclear fuel and GTCC low-level radioactive waste, and some shutdown sites have two options.

Table 6-1. Summary of Transportation Mode Options for Shipments from Shutdown Sites

\begin{tabular}{|c|c|c|c|}
\hline Site & $\begin{array}{l}\text { Primary } \\
\text { Mode }\end{array}$ & $\begin{array}{l}\text { Secondary } \\
\text { Mode }\end{array}$ & Comments \\
\hline Maine Yankee & Direct rail & Barge to rail & $\begin{array}{l}\text { The condition of the onsite rail spur and Maine } \\
\text { Eastern Railroad would need to be verified }\end{array}$ \\
\hline Yankee Rowe & $\begin{array}{l}\text { Heavy haul } \\
\text { truck to rail }\end{array}$ & - & $\begin{array}{l}\text { The heavy haul would be } 7.5 \text { miles to the east portal } \\
\text { of the Hoosac Tunnel. }\end{array}$ \\
\hline $\begin{array}{l}\text { Connecticut } \\
\text { Yankee }\end{array}$ & Barge to rail & $\begin{array}{l}\text { Heavy haul } \\
\text { truck to rail }\end{array}$ & $\begin{array}{l}\text { The barge canal would probably have to be dredged } \\
\text { before use. }\end{array}$ \\
\hline Humboldt Bay & Barge to rail & $\begin{array}{l}\text { Heavy haul } \\
\text { truck to rail }\end{array}$ & $\begin{array}{l}\text { The condition of the Fields Landing Terminal would } \\
\text { need to be verified. The heavy haul distance would } \\
\text { be over } 160 \text { miles. }\end{array}$ \\
\hline Big Rock Point & $\begin{array}{l}\text { Heavy haul } \\
\text { truck to rail }\end{array}$ & Barge to rail & $\begin{array}{l}\text { The heavy haul would probably be about } 52 \text { miles to } \\
\text { Gaylord, Michigan. A shorter heavy haul of } 13 \text { miles } \\
\text { to Petoskey, Michigan may be possible. }\end{array}$ \\
\hline Rancho Seco & Direct rail & - & The rail spur would need to be refurbished. \\
\hline Trojan & Direct rail & Barge to rail & The onsite rail spur would need to be refurbished. \\
\hline La Crosse & Direct rail & Barge to rail & The onsite rail spur would need to be refurbished. \\
\hline Zion & Direct rail & Barge to rail & $\begin{array}{l}\text { The rail spur is being refurbished to support reactor } \\
\text { decommissioning waste shipments. }\end{array}$ \\
\hline
\end{tabular}

Based on the activities and task durations presented in Section 5 of this report, preparing for and removing the used nuclear fuel and GTCC low-level radioactive waste from the nine shutdown sites could be accomplished in 11.5 to 14.5 years. This time period was largely driven by the time required to load and transport the used nuclear fuel and GTCC low-level radioactive waste; procure casks, components, and campaign kits; and the time required to procure railcars that meet AAR Standard S-2043. While the latter two activities could take place in parallel, they still represent a significant fraction of the time it would take to prepare for and remove the used nuclear fuel and GTCC low-level radioactive waste from the shutdown sites.

As part of this preliminary evaluation, three shutdown sites were visited: Maine Yankee, Yankee Rowe, and Connecticut Yankee. In order to confirm the information in this report and to refine 
the estimates of activities and task durations, it is recommended that the six remaining shutdown sites (Humboldt Bay, Big Rock Point, Rancho Seco, Trojan, La Crosse, and Zion) be visited.

The estimates of durations for project tasks presented here are preliminary and depend on the many identified assumptions. Consequently, in preparing a comprehensive project plan to prepare for and remove used nuclear fuel from the nine shut down sites it will be necessary to refine the estimates using improved information regarding each of the sites and their near-site transportation infrastructure and using methods that will allow managers to gauge the importance of assumptions and project considerations. In this regard, it is recommended that DOE use a quantitative risk analysis tool such as Primavera Risk Analysis (formerly known as Pertmaster) in conjunction with a scheduling tool such as Primavera P6 to provide estimates of project risks and opportunities. Such quantitative analyses would support estimating, managing, and funding of contingencies, and would increase confidence in the project would be successfully executed. Risk-informed estimates would also allow the project's managers to anticipate time and funding resources, and alternative courses of action that might be needed to effectively respond to changing circumstances.

DOE should also take advantage of improved information regarding loading and transportation of used nuclear fuel from the nine shutdown sites to refine the data used by the DOE TOM to evaluate optimizations that may be possible in acquiring and using transportation resources. TOM could also be used to conduct sensitivity analyses and identify important gaps in information that could be filled with additional data collected from the shutdown sites. Information developed using TOM could also be used in case studies conducted using the quantitative analysis tools discussed above. 
Nuclear Fuels Storage and Transportation Planning Project

A Preliminary Evaluation of Removing Used Nuclear Fuel From Nine Shutdown Sites 


\section{REFERENCES}

10 CFR 71. "Packaging and Transportation of Radioactive Material.” Code of Federal Regulations, U.S. Nuclear Regulatory Commission.

10 CFR 72. "Licensing Requirements for the Independent Storage of Spent Nuclear Fuel, HighLevel Radioactive Waste, and Reactor-Related Greater Than Class C Waste.” Code of Federal Regulations, U.S. Nuclear Regulatory Commission.

49 CFR 213. “Track Safety Standards.” Code of Federal Regulations, Federal Railroad Administration.

63 FR 67976-67979. December 9, 1998. "Northwestern Pacific Railroad; Emergency Order to Prevent Operation of Trains on Northwestern Pacific Railroad's Trackage from Arcata, California, to Mile Post 63.4 Between Schellville and Napa Junction, California.” Federal Register, Federal Railroad Administration, FRA Emergency Order No. 21, Notice No. 1.

76 FR 27171-27172. May 10, 2011. "Northwestern Pacific Railroad Co.; Notice of Partial Relief from Emergency Order No. 21.” Federal Register, Federal Railroad Administration, FRA Emergency Order No. 21, Notice No. 4.

42 U.S.C. 10101 et seq. Nuclear Waste Policy Act of 1982, as amended.

AAR (Association of American Railroads). 2008. Performance Specification for Trains Used to Carry High-Level Radioactive Material. Standard S-2043, Association of American Railroads, Washington, D.C.

AC\&T (American Cranes \& Transport). 2011. Site Report: Transport. Vol. 7, Issue 7, pp. 3839.

BRC. 2012. Blue Ribbon Commission on America's Nuclear Future, Report to the Secretary of Energy. Prepared by the Blue Ribbon Commission on America's Nuclear Future for the U.S. Department of Energy, Washington, D.C.

Connecticut Yankee. 2012. “CY Snapshots.” Accessed October 20, 2012 at http://www.connyankee.com/html/transformer.html.

DOE (U.S. Department of Energy). 2009. National Transportation Plan. Report No.

DOE/RW-0603, Revision 0. Office of Civilian Radioactive Waste Management, Washington, D.C.

Dominion. 2012. Dominion to Close, Decommission Kewaunee Power Station. Press Release October 22, 2012. Accessed April 1, 2013 at http://dom.mediaroom.com/2012-10-22-DominionTo-Close-Decommission-Kewaunee-Power-Station. 
DSI (DeskMap Systems, Inc.). 2004. Professional Railroad Atlas of North America. Third Edition. Railroad Information Services. Austin, Texas.

Duke Energy 2013. “Crystal River Nuclear Plant to be retired; company evaluating sites for potential new gas-fueled generation.” Press Release February 5, 2013. Accessed April 1, 2013 at http://www.duke-energy.com/news/releases/2013020501.asp.

EIA (Energy Information Agency). 2002. “2002 Form RW-859 Nuclear Fuel Data Survey Database.” Energy Information Agency, Washington, D.C.

EPRI (Electric Power Research Institute). 1998. Yankee Rowe Decommissioning Experience Record: Volume 2. EPRI Report Number TR-107917-V2, Electric Power Research Institute, Palo Alto, California.

EPRI (Electric Power Research Institute). 2005. Maine Yankee Decommissioning-Experience Report: Detailed Experiences 1997-2004. EPRI Report Number 1011734, Electric Power Research Institute, Palo Alto, California.

EPRI (Electric Power Research Institute). 2006. Connecticut Yankee Decommissioning Experience Report: Detailed Experiences 1996-2006. EPRI Report Number 1013511, Electric Power Research Institute, Palo Alto, California.

EPRI (Electric Power Research Institute). 2010. Industry Spent Fuel Storage Handbook. EPRI Report Number 1021048, Electric Power Research Institute, Palo Alto, California.

Exelon. 2010. Exelon to Retire Oyster Creek Generating Station in 2019. Press Release December 8, 2010. Accessed April 1, 2013 at http://www.exeloncorp.com/newsroom/pr_20101208_Nuclear_OysterCreekRetirement.aspx.

Feigenbaum T. 2005. “Maine Yankee Reactor Vessel Removal and Barge Transport.” Presentation to the U.S. Department of Energy TEC Working Group, April 4-5, 2005, Phoenix, Arizona.

Google, Inc. 2012. Google Earth (Version 6.2.2.6613). Available at http://www.google.com/earth/index.html.

HBHRCD (Humboldt Bay Harbor, Recreation \& Conservation District). 2012. Humboldt Bay Shipping Terminals. Accessed October 24, 2012 at http://www.humboldtbay.org/portofhumboldtbay/terminals/.

Herron JT. 2010. Statement of John T. Herron. Blue Ribbon Commission on America's Nuclear Future, Transportation and Storage Subcommittee Meeting, November 2, 2010, Chicago, Illinois.

IAEA (International Atomic Energy Agency). 2012. Power Reactor Information System (PRIS). Available at www.iaea.org/pris. 
Johnson K. 2006. "Segmenting and Disposing of the Rancho Seco Reactor Vessel Internals." Radwaste Solutions, 13(5):37-50.

Lackey MB and ML Kelly. 1996. “The Trojan Large Component Removal Project.” In Proceedings of the ASME-JSME $4^{\text {th }}$ International Conference on Nuclear Engineering 1996 (ICONE-4), New Orleans, Louisiana, March 10-14, 1996, pp. 89-94.

Lackey MB and ML Kelly. 1997. “The Trojan Large-Component Removal Project.” Radwaste Magazine, 4(1):11-17.

Leduc DR. 2012. Dry Storage of Used Fuel Transition to Transport. Report No.

FCRD-UFD-2012-000253. U.S. Department of Energy, Washington, D.C.

Lessard L. 2000. "Safe from Start to Finish, The 1100-Mile Journey of the Yankee Rowe Reactor Pressure Vessel.” Radwaste Solutions, 7(2):44-49.

NAC. 1991a. Near-Site Transportation Infrastructure Project Draft Report and Assessment, Rancho Seco Nuclear Generating Station. DOE Records Information System Accession Number MOV.20000107.0010. NAC International, Norcross, Georgia.

NAC. 1991b. Near-Site Transportation Infrastructure Project Draft Report and Assessment, Trojan Nuclear Plant. NAC Report No. CA-89108S. NAC International, Norcross, Georgia.

NRC (U.S. Nuclear Regulatory Commission). 2007. Classifying the Condition of Spent Nuclear Fuel for Interim Storage and Transportation Based on Function. Division of Spent Fuel Storage and Transportation Interim Staff Guidance - 1, Revision 2. Accession Number ML0714208.

NRC (U.S. Nuclear Regulatory Commission). 2009. Safety Evaluation Report, Docket No. 72-11, Sacramento Municipal Utility District, Rancho Seco Independent Spent Fuel Storage Installation, License No. SNM-2510, Amendment No. 3. Accession Number ML092240439.

NRC (U.S. Nuclear Regulatory Commission). 2010. Big Rock Point Independent Spent Fuel Storage Installation Inspection Reports 072-00043/10-01 (DNMS) and 050-00155/1001(DNMS). Accession Number ML103420157.

NRC (U.S. Nuclear Regulatory Commission). 2012a. 2012-2013 Information Digest. NUREG-1350, Volume 24. U.S. Nuclear Regulatory Commission, Office of Public Affairs, Washington, D.C.

NRC (U.S. Nuclear Regulatory Commission). 2012b. NRC Inspection Report 050-00133/12010. Accession Number ML12248A335. U.S. Nuclear Regulatory Commission, Washington, D.C. 
NRC (U.S. Nuclear Regulatory Commission). 2012c. Letter re: Certificate of Compliance No. 9276, Revision No. 4, for the Model FuelSolutions TS125 Transportation Package (Docket No. 71-9276) (TAC L24684). Accession Number ML12306A387. U.S. Nuclear Regulatory Commission, Washington, DC.

Petrosky T. 2004. “The Big Rock Vessel Goes to Barnwell.” Radwaste Solutions, 11(1):15-18.

Radwaste Magazine. 1999. “Cruisin’ Up the River, The Final Journey of the Trojan Reactor Vessel.” Radwaste Magazine, 6(6):48-53.

Radwaste Solutions. 2000. "Moving to Another Stage of Life, Shipping, Decontaminating, and Final Disposition of the Maine Yankee Large Components.” Radwaste Solutions, 7(5):50-55.

Radwaste Solutions. 2007. "La Crosse BWR Reactor Vessel Shipped to Barnwell.” Radwaste Solutions, 14(5):30-32.

Redeker S. 2006. Docket No. 72-11, Rancho Seco Independent Spent Fuel Storage Installation, License No. SNM-2510, Special Report Regarding a Violation of 10 CFR Part 72 Technical Specification 2.1.1. Accession Number ML063470045.

Stoddard DG. 2013. Dominion Energy Kewaunee, Inc., Kewaunee Power Station, Certification of Permanent Cessation of Power Operations. Accession Number ML13058A065. February 25.

STB (Surface Transportation Board). 2012. “FAQs.” Surface Transportation Board, U.S. Department of Transportation. Accessed October 20, 2012 at http://stb.dot.gov/stb/faqs.html.

Tompkins B. 2006. “Big Rock Point: From Groundbreaking to Greenfield.” Nuclear News, 49(12):36-43.

TOPO (Transportation Operations Project Office). 1993a. Maine Yankee Atomic Power Station, Maine Yankee Atomic Power Company, Site and Facility Transportation Services Planning Document. DOE Records Information System Accession Number HQV.940228.0020. Oak Ridge, Tennessee.

TOPO (Transportation Operations Project Office). 1993b. Yankee-Rowe Atomic Power Station, Yankee Atomic Electric Company, Site and Facility Transportation Services Planning Document. DOE Records Information System Accession Number HQV.931215.0018. Oak Ridge, Tennessee.

TOPO (Transportation Operations Project Office). 1993c. Haddam Neck Nuclear Generating Station, Connecticut Yankee Atomic Power Company, Northeast Utilities Company, Site and Facility Transportation Services Planning Document. DOE Records Information System Accession Number HQV.931101.0004. Oak Ridge, Tennessee. 
TOPO (Transportation Operations Project Office). 1993d. Humboldt Bay Power Plant Unit 3, Pacific Gas and Electric Company, Site and Facility Transportation Services Planning Document. DOE Records Information System Accession Number HQV.931101.0005. Oak Ridge, Tennessee.

TOPO (Transportation Operations Project Office). 1993e. La Crosse Nuclear Power Station, Dairyland Power Cooperative, Site and Facility Transportation Services Planning Document. DOE Records Information System Accession Number HQV.931101.0007. Oak Ridge, Tennessee.

TOPO (Transportation Operations Project Office). 1994a. Big Rock Point Nuclear Station, Consumers Power Company, Site and Facility Transportation Services Planning Document. Oak Ridge, Tennessee.

TOPO (Transportation Operations Project Office). 1994b. Zion Nuclear Power Station Units 1 and 2, Commonwealth Edison Company, Site and Facility Transportation Services Planning Document. DOE Records Information System Accession Number MOV.19940919.0002. Oak Ridge, Tennessee.

TriVis Incorporated. 2005. Facility Interface Review and Update, Final Report on Facility Interfaces for the Office of Civilian Radioactive Waste Management. DOE Records Information System Accession Number MOL.20060121.0173. Pelham, Alabama.

Troher K. 2011. “Reactor Head Goes Through Kenosha County On Way to Utah.” Kenosha News. December 2, 2011.

USACE (U.S. Army Corps of Engineers). 2012. Five-Year Programmatic Assessment and 404(b)(1) Analysis, Humboldt Harbor and Bay Operations and Maintenance Dredging (FY 2012-FY 2016), Humboldt Bay, Humboldt County, California. U.S. Army Corps of Engineers, San Francisco Bay District.

Ux Consulting. 2012. StoreFUEL and Decommissioning Report. 13(170).

Washington Nuclear Corporation. 2003. SpentFUEL. 10(483).

Wheeler DM. 2002. “Large Component Removal/Disposal.” WM’02 Conference Proceedings. February 24-28, 2002, Tucson, Arizona. Available at http://www.wmsym.org/archives/2002/Proceedings/44/573.pdf.

ZionSolutions. 2012. “ZCAP Update August 27, 2012.” Zion Station Community Advisory Panel (ZCAP) Meeting, August 27, 2012, Zion, Illinois. 
Nuclear Fuels Storage and Transportation Planning Project

A Preliminary Evaluation of Removing Used Nuclear Fuel From Nine Shutdown Sites

136

April 30, 2013 
Nuclear Fuels Storage and Transportation Planning Project

A Preliminary Evaluation of Removing Used Nuclear Fuel From Nine Shutdown Sites

April 30, 2013

\section{Appendix A}

\section{U.S. Nuclear Regulatory Commission Certificates of Compliance}


Nuclear Fuels Storage and Transportation Planning Project

A Preliminary Evaluation of Removing Used Nuclear Fuel From Nine Shutdown Sites 


\section{Appendix A \\ U.S. Nuclear Regulatory Commission Certificates of Compliance}

Table A-1 lists the docket number, package identification number, revision number, certificate of compliance expiration date, and ADAMS accession number for the transportation casks licensed to transport used nuclear fuel from the shutdown sites. Table A-2 lists the docket number, certificate of compliance number issue date, certificate of compliance expiration date, amendment number, amendment effective date, and ADAMS accession number for the general licensed storage systems used at the shutdown sites. It should be noted that Humboldt Bay, Rancho Seco, and Trojan store used nuclear fuel based on a site-specific license.

Table A-1. Transportation Casks Licensed to Transport Used Nuclear Fuel from the Shutdown Sites

\begin{tabular}{|l|l|l|l|l|l|}
\hline $\begin{array}{l}\text { Transportation } \\
\text { Cask }\end{array}$ & Docket & $\begin{array}{l}\text { Package Identification } \\
\text { Number }\end{array}$ & Revision & $\begin{array}{l}\text { Certificate of } \\
\text { Compliance } \\
\text { Expiration } \\
\text { Date }\end{array}$ & $\begin{array}{l}\text { ADAMS } \\
\text { Accession } \\
\text { Number }\end{array}$ \\
\hline NAC-STC & $71-9235$ & USA/9235/B(U)F-96 & 12 & $05 / 31 / 2014$ & ML102780253 \\
\hline MP187 & $71-9255$ & USA/9255/B(U)F-85 & 10 & $11 / 30 / 2013$ & ML083300410 \\
\hline $\begin{array}{l}\text { HI-STAR 100 and } \\
\text { HI-STAR HB }\end{array}$ & $71-9261$ & USA/9261/B(U)F-96 & 8 & $03 / 31 / 2014$ & ML102860108 \\
\hline NAC-UMS UTC & $71-9270$ & USA/9270/B(U)F-96 & 4 & $10 / 31 / 2017$ & ML12306A440 \\
\hline TS125 & $71-9276$ & USA/9276/B(U)F-85 & 4 & $10 / 31 / 2017$ & ML12306A387 \\
\hline MAGNATRAN & $71-9356$ & -- & -- & -- & - \\
\hline $\begin{array}{l}\text { ADAMS= Agencywide Documents Access and Management System (http://www.nrc.gov/reading- } \\
\text { rm/adams.html) }\end{array}$
\end{tabular}

Table A-2. General Licensed Storage Systems Used at the Shutdown Sites

\begin{tabular}{|l|l|l|l|l|l|l|}
\hline Storage System & Docket & $\begin{array}{l}\text { Certificate of } \\
\text { Compliance } \\
\text { Issue Date }\end{array}$ & $\begin{array}{l}\text { Certificate of } \\
\text { Compliance } \\
\text { Expiration Date }\end{array}$ & Amendment & $\begin{array}{l}\text { Amendment } \\
\text { Effective } \\
\text { Date }\end{array}$ & $\begin{array}{l}\text { ADAMS } \\
\text { Accession } \\
\text { Number }\end{array}$ \\
\hline NAC-UMS & $72-1015$ & $11 / 20 / 2000$ & $11 / 20 / 2020$ & 5 & $01 / 12 / 2009$ & ML090120408 \\
\hline NAC-MPC & $72-1025$ & $04 / 10 / 2000$ & $04 / 10 / 2020$ & 6 & $10 / 04 / 2010$ & ML102920618 \\
\hline $\begin{array}{l}\text { Fuel Solutions } \\
\text { Storage System }\end{array}$ & $72-1026$ & $02 / 15 / 2001$ & $02 / 15 / 2021$ & 4 & $07 / 03 / 2006$ & ML061910527 \\
\hline MAGNASTOR & $72-1031$ & $02 / 04 / 2009$ & $02 / 04 / 2029$ & 2 & $01 / 30 / 2012$ & ML12144A070 \\
\hline $\begin{array}{l}\text { ADAMS= Agencywide Documents Access and Management System (http://www.nrc.gov/reading- } \\
\text { rm/adams.html) }\end{array}$
\end{tabular}

